\title{
Podjetništvo v novi stvarnosti GEM Slovenija 2020
}

Miroslav Rebernik Karin Širec

Barbara Bradač Hojnik

Katja Crnogaj

Matej Rus

Polona Tominc

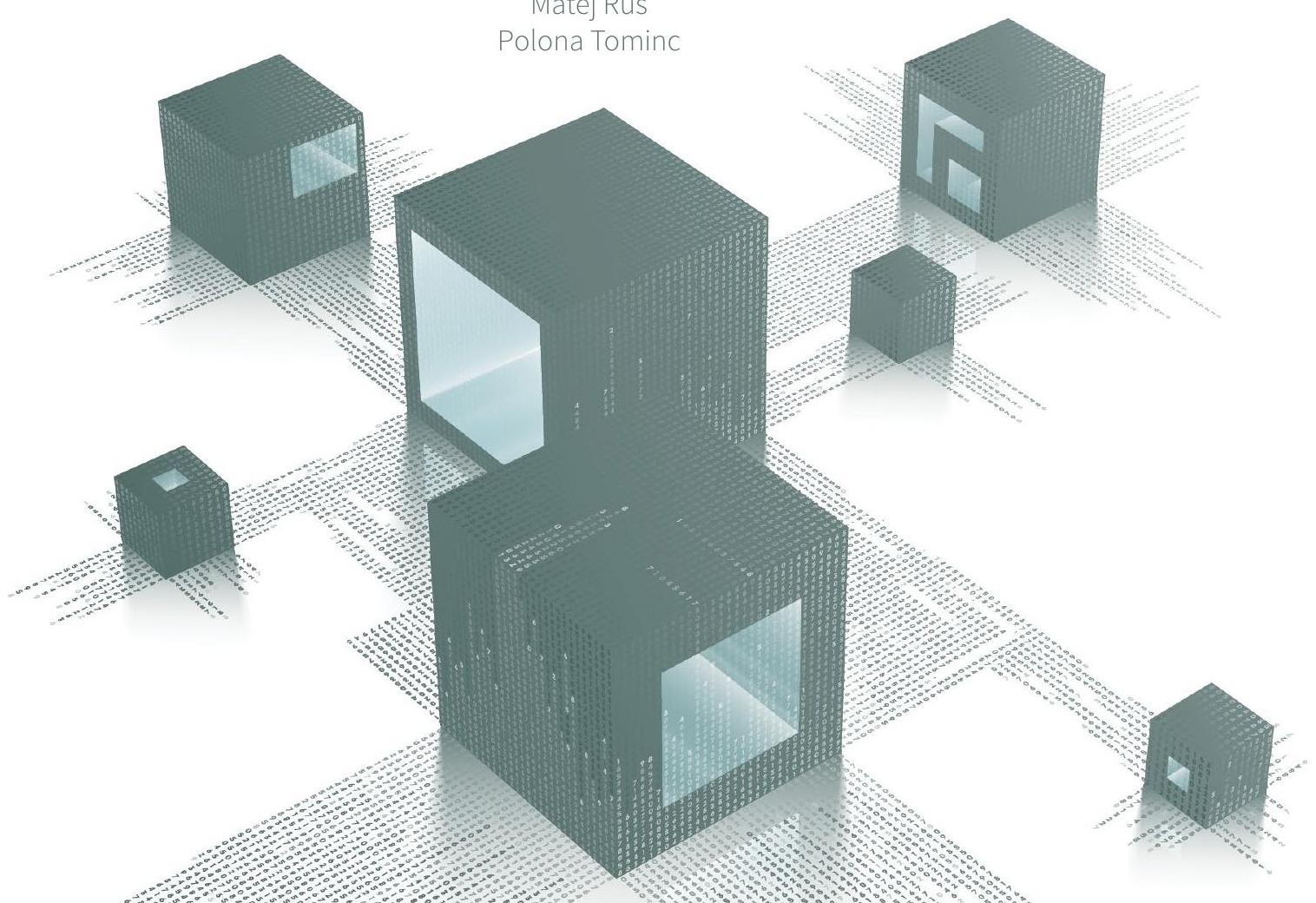





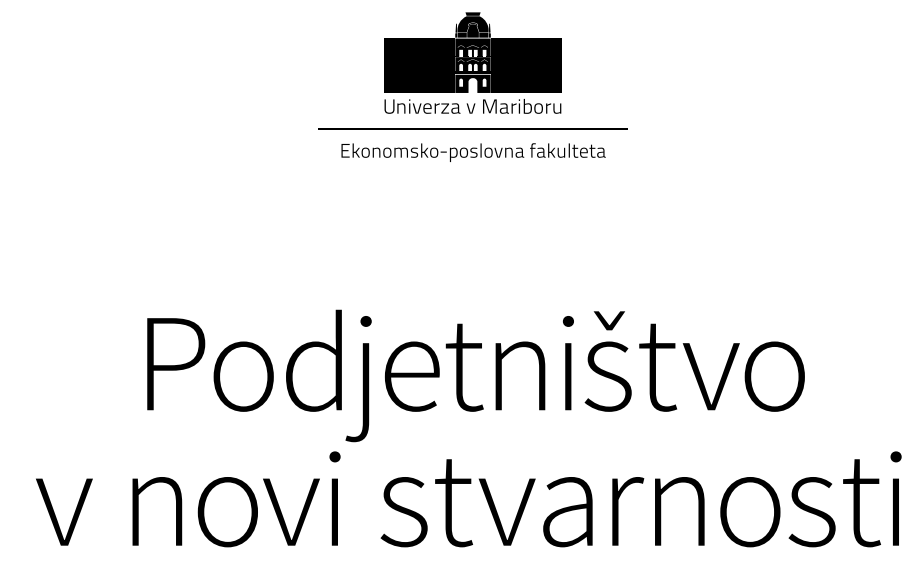

GEM Slovenija 2020

\author{
Urednika: \\ Miroslav Rebernik \\ Karin Širec \\ Avtorji: \\ Miroslav Rebernik \\ Karin Širec \\ Barbara Bradač Hojnik \\ Katja Crnogaj \\ Matej Rus \\ Polona Tominc
}

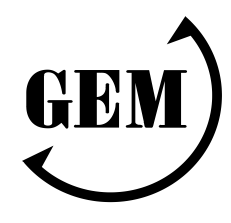


Knjižna zbirka: Slovenski podjetniški observatorij

ISSN: $1854-8040$

Naslov: Podjetništvo v novi stvarnosti

Podnaslov: GEM Slovenija 2020

Title: Entrepreneurship in a New Reality

Subtitle: GEM Slovenia 2020

Urednika: Miroslav Rebernik (Univerza v Mariboru, Ekonomsko-poslovna fakulteta) Karin Širec (Univerza v Mariboru, Ekonomsko-poslovna fakulteta)

Avtorji: Miroslav Rebernik, Karin Širec, Barbara Bradač Hojnik, Katja Crnogaj, Matej Rus, Polona Tominc

Recenzija: Slavica Singer (Univerza v Osijeku, Ekonomska fakulteta)

Mitja Ruzzier (Univerza na Primorskem, Fakulteta za management)

Jezikovni pregled: Darja Gabrovšek Homšak

Grafične priloge: avtoriji

Oblikovanje: Nebia, d.o.o.

Založnik: Univerza v Mariboru, Univerzitetna založba, Slomškov trg 15, 2000 Maribor, Slovenija https://press.um.si, zalozba@um.si

Izdajatelj: Univerza v Mariboru, Ekonomsko-poslovna fakulteta, Razlagova ulica 14, 2000 Maribor, Slovenija, https://www.epf.um.si, epf@mb.si

Izdaja: prva izdaja

Vrsta publikacije: e-knjiga

Dostopno na: http://press.um.si/index.php/ump/catalog/book/569

Izid: Maribor, maj 2021

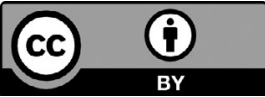

(c) Univerza v Mariboru, Univerzitetna založba

Tekst / Text @ avtorji in Rebernik, Širec 2021

To delo je objavljeno pod licenco Creative Commons Priznanje avtorstva 4.0 Mednarodna. /

This work is licensed under the Creative Commons Attribution 4.0 International License.

Uporabnikom je dovoljeno tako nekomercialno kot tudi komercialno reproduciranje,

distribuiranje, dajanje v najem, javna priobčitev in predelava avtorskega dela, pod pogojem, da navedejo avtorja izvirnega dela.

Vsa gradiva tretjih oseb v tej knjigi so objavljena pod licenco Creative Commons, razen če to ni navedeno drugače. Če želite ponovno uporabiti gradivo tretjih oseb, ki ni zajeto v licenci Creative Commons, boste morali pridobiti dovoljenje neposredno od imetnika avtorskih pravic. https://creativecommons.org/licenses/by/4.0/

Izšlo v knjižni zbirki »Slovenski podjetniški observatorijk.

Slovenski podjetniški observatorij financirajo Javna agencija Republike Slovenije za spodbujanje podjetništva, internacionalizacije, tujih investicij in tehnologije - SPIRIT, Ministrstvo za gospodarski razvoj in tehnologijo RS in Javna agencija za raziskovalno dejavnost RS.

CIP - Kataložni zapis o publikaciji

Univerzitetna knjižnica Maribor

334.7"2021"(497.4)(0.034.2)

PODJETNIŠTVO v novi stvarnosti [Elektronski vir] : GEM Slovenija 2020 / avtorji Miroslav Rebernik ... [et al.] ; urednika Miroslav Rebernik, Karin Širec ; izdajatelj Univerza v Mariboru, Ekonomsko-poslovna fakulteta. - 1. izd. - E-knjiga. - Maribor : Univerza v Mariboru, Univerzitetna založba, 2021. - (Slovenski podjetniški observatorij, ISSN 1854-8040) Način dostopa (URL): https://press.um.si/index.php/ump/catalog/book/569

ISBN 978-961-286-467-5

doi: 10.18690/978-961-286-467-5

1. Rebernik, Miroslav 2. Širec, Karin

COBISS.SIIID 62843907

ISBN: 978-961-286-467-5 (pdf), 978-961-286-468-2 (Mehka vezava)

DOI: https://doi.org/10.18690/978-961-286-467-5

Cena: Brezplačen izvod

Odgovorna

oseba založnika: prof. dr. Zdravko Kačič, rektor Univerze v Mariboru

Citiranje: Rebernik, M. in Širec, K. (ur.) (2021). Podjetništvo v novi stvarnosti: GEM Slovenija 2020.

Maribor: Univerzitetna založba. doi: 10.18690/978-961-286- 467-5 


\section{Kazalo}

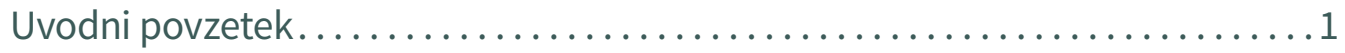

Predstavitev Globalnega podjetniškega monitorja $\ldots \ldots \ldots \ldots \ldots \ldots \ldots \ldots \ldots \ldots \ldots \ldots 1$

Podjetniška zmogljivost odraslega prebivalstva in zaznavanje odnosa do podjetništva

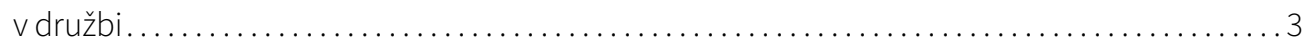

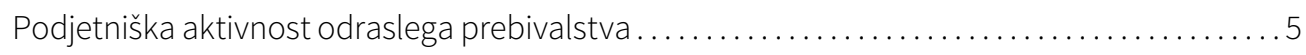

Demografske značilnosti slovenskega podjetništva $\ldots \ldots \ldots \ldots \ldots \ldots \ldots \ldots \ldots \ldots \ldots . \ldots \ldots$

Podjetniške aspiracije .................................................

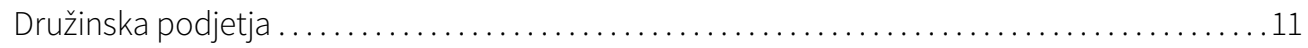

Kakovost podjetniškega ekosistema .......................................12

1 Uvodna predstavitev GEM . . . . . . . . . . . . . . . . . . . . . . . . . . 15

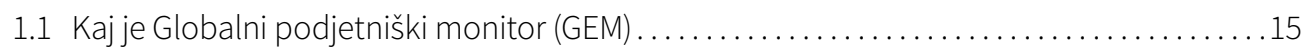

1.2 Konceptualni okvir GEM in spremljanje podjetniškega ekosistema in procesa .........17

1.3 Podatkovne podlage za GEM . ........................................21

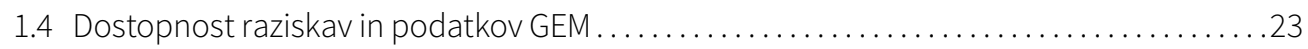

Nacionalni profil: Slovenija $\ldots \ldots \ldots \ldots \ldots \ldots \ldots \ldots \ldots \ldots . \ldots . \ldots . \ldots \ldots$

2 GEM-ova preglednica značilnosti podjetništva v Sloveniji. ............27

3 Podjetniška zmogljivost odraslega prebivalstva in zaznavanje odnosa do

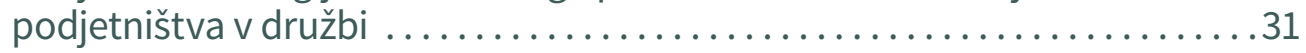

3.1 Samozaznavanje in dojemanje podjetništva z vidika posameznika .................33

3.2 Zaznavanje družbenih vrednot o podjetništvu ............................ 39

4 Podjetniška aktivnost odraslega prebivalstva ... . . . . . . . . . . . . 45

4.1 Faze in učinkovitost podjetniškega procesa .............................. 46

4.2 Zgodnja podjetniška aktivnost ........................................... 49

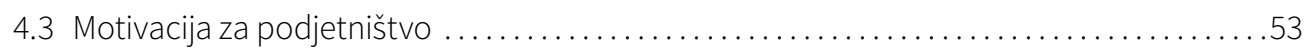

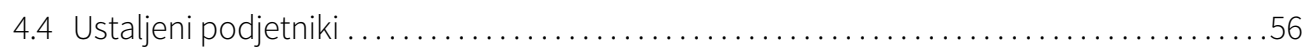

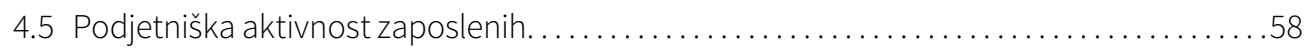

4.6 Izstop podjetnikov ................................................61

5 Demografske značilnosti slovenskega podjetništva ..............65

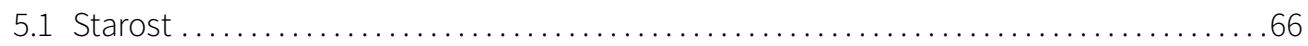

5.2 Podjetništvo in mladi ................................................. 69

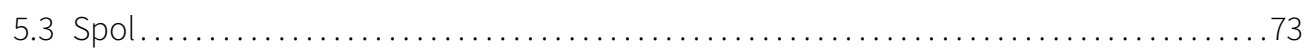

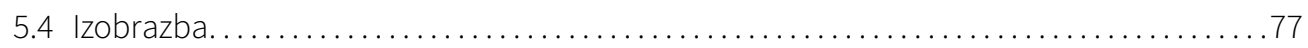

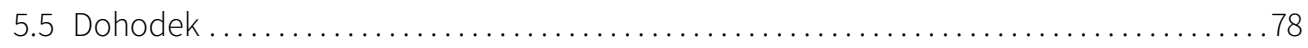




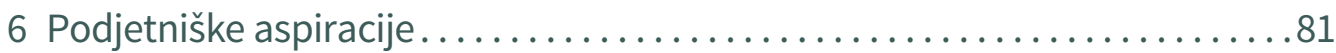

6.1 Ambicioznost podjetnikov .......................................... 82

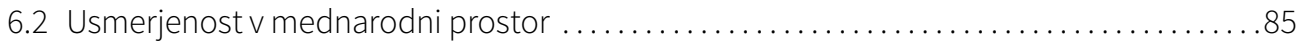

6.3 Inovacijska naravnanost zgodnjih podjetnikov ........................... 88

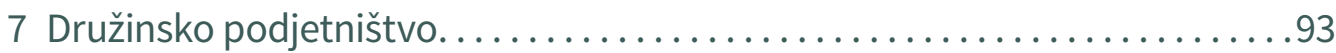

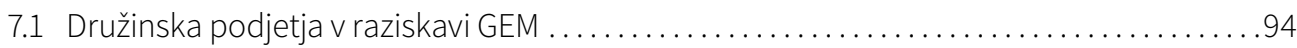

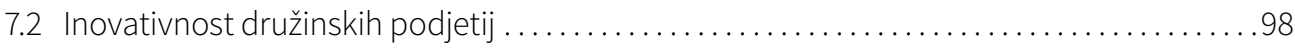

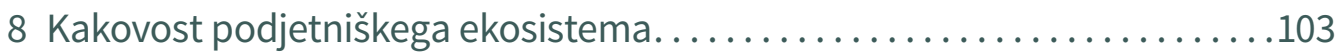

8.1 Ocena okvirnih pogojev za podjetništvo ............................... 104

8.2 Indeks nacionalnega podjetniškega konteksta (NECI) . . . . . . . . . . . . . . . . . . 113

8.3 Zgodnji vpliv in učinek pandemije covida-19 za nova in rastoča podjetja . ...........116

8.4 Priporočila slovenskih izvedencev za izboljšanje podjetniškega okolja ...............120

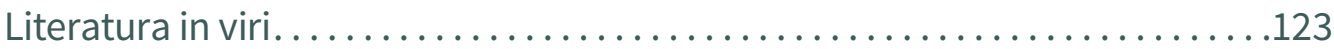

P1 Značilnosti vzorca slovenskih izvedencev v letu $2020 \ldots \ldots \ldots \ldots \ldots . . \ldots 131$

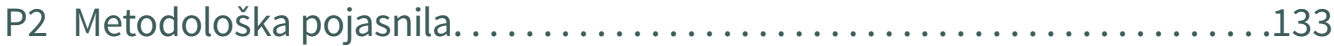

Razlika med podatki GEM in podatki poslovnih registrov ali AJPES . . . . . . . . . . . . . . 133

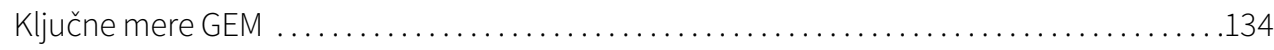

GEM-ovi okvirni pogoji za podjetništvo, GEM 2020, NES ........................138

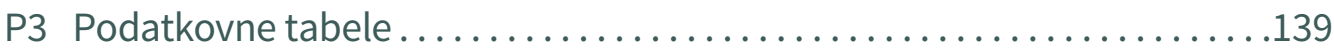

P4 Raziskovalni timi in sponzorji GEM v letu $2020 \ldots \ldots \ldots \ldots \ldots \ldots \ldots . \ldots 147$

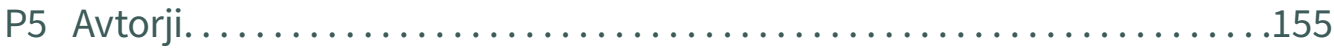




\section{Kazalo slik}

Slika 1.1: Konceptualni okvir GEM ...................................................................................................... 19

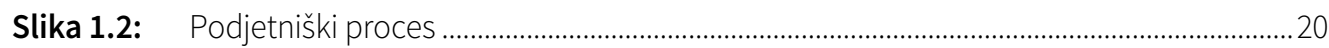

Slika 3.1: Elementi podjetniške zmogljivosti, Slovenija in povprečje evropskih držav ...................33

Slika 3.2: Zaznavanje poslovnih priložnosti (v evropskih državah GEM)..........................................34

Slika 3.3: Zaznavanje poslovnih priložnosti in zaznana enostavnost ustanoviti podjetje (v evropskih državah GEM)............................................................................................

Slika 3.4: Zaznano podjetniško znanje, izkušnje in sposobnosti (v evropskih državah GEM) .....36

Slika 3.5: Strah pred neuspehom ter zaznavanje poslovnih priložnosti ( $v$ evropskih državah GEM)

Slika 3.6: Zaznavanje velikega vpliva pandemije na podjetniške namere (v evropskih državah GEM)

Slika 3.7: Zaznavanje vsaj majhnega vpliva pandemije na podjetniške namere (v evropskih državah GEM)

Slika 3.8: Podjetniške namere med tistimi, ki niso vključeni v nobeno podjetniško aktivnost (v evropskih državah GEM) ................................................................................................39

Slika 3.9: Zaznavanje družbenih vrednot o podjetništvu ..............................................................40

Slika 3.10: Odstotek ljudi, ki menijo, da je podjetništvo primerna izbira karierne poti (v evropskih državah GEM)

Slika 3.11: Odstotek ljudi, ki menijo, da so uspešni podjetniki v družbi spoštovani (v evropskih državah GEM)

Slika 3.12: Odstotek ljudi, ki zaznavajo medijsko podporo podjetništvu v družbi (v evropskih državah GEM)

Slika 4.1: $\quad$ Izbrani kazalniki podjetniškega procesa v Sloveniji ............................................................4 47

Slika 4.2: Puščanje podjetniškega voda v Sloveniji ...............................................................................48

Slika 4.3: Celotna zgodnja podjetniška aktivnost (v evropskih državah GEM) ................................50

Slika 4.4: Celotna zgodnja podjetniška aktivnost v Sloveniji v letih od 2010 do 2020 ....................51

Slika 4.5: Indeks TEA vizbranih skupinah držav........................................................................51

Slika 4.6: Nastajajoči podjetniki s težavami pri prehodu med nove podjetnike zaradi krize zaradi covida-19 (v evropskih državah GEM).

Slika 4.7: $\quad$ Zgodnji podjetniki, ki so v krizi zaradi covida-19 zaznali nove priložnosti (v evropskih državah GEM)

Slika 4.8: Motivacija za podjetništvo v Sloveniji in povprečju evropskih držav..................................56

Slika 4.9: Odstotek ustaljenih podjetnikov med odraslim prebivalstvom (v evropskih državah GEM) .................................................................................................57

Slika 4.10: Ustaljeni podjetniki v izbranih skupinah držav................................................................57

Slika 4.11: Ustaljeni podjetniki kot odstotek odraslega prebivalstva v Sloveniji v letih od 2010 do 2020 
Slika 4.12: Podjetniška aktivnost zaposlenih kot odstotek odrasle populacije

(v evropskih državah GEM)

Slika 4.13: Sponzorirana zgodnja podjetniška aktivnost kot odstotek odrasle populacije

( v evropskih državah GEM).

Slika 4.14: Izstop podjetnika v zadnjih 12 mesecih z nadaljevanjem in brez nadaljevanja posla ( $v$ evropskih državah GEM).....

Slika 4.15: Glavne skupine razlogov za prenehanje poslovanja v Sloveniji 63

Slika 5.1: Podjetniška aktivnost v Sloveniji glede na starost 67

Slika 5.2: Zgodnja podjetniška aktivnost po motivih in starostnih razredih 69

Slika 5.3: Število in delež mladih v registrirani brezposelnosti .70

Slika 5.4: Odstotek nastajajočih in novih ter ustaljenih podjetnikov, mlajših od 34 let .71

Slika 5.5: Podjetniška aktivnost nastajajočih, novih in ustaljenih podjetnikov, mlajših od 34 let

Slika 5.6: Izobrazbena raven nastajajočih in novih podjetnikov po starostnih skupinah od 18 do 34 let in od 35 do 64 let .72

Slika 5.7: Zgodnja podjetniška aktivnost moških in žensk (v evropskih državah GEM) ................. 74

Slika 5.8: Razmerje v zgodnji in ustaljeni podjetniški aktivnosti med spoloma ............................75

Slika 5.9: Podjetniška aktivnost v Sloveniji glede na starost in spol ................................................... 76

Slika 5.10: Zgodnja podjetniška aktivnost po motivih in spolu ..........................................................77

Slika 5.11: Izobrazba nastajajočih, novih in ustaljenih podjetnikov in nepodjetnikov .................... 78

Slika 5.12: Dohodkovni razredi v celotnem podjetniškem procesu .................................................... 79

Slika 6.1: Pričakovanja podjetnikov, da v petih letih ustvarijo več kot pet delovnih mest, vTEA (v evropskih državah GEM)

Slika 6.2: Načrti podjetnikov o zaposlovanju po skupinah držav. .84

Slika 6.3: Podjetniki, ki že zaposlujejo oziroma to načrtujejo, v celotni populaciji (v evropskih državah GEM). .85

Slika 6.4: Geografski izvor kupcev podjetij po skupinah držav ..........................................................86

Slika 6.5: Delež kupcev podjetja iz globalnega okolja, v TEA (v evropskih državah GEM) .............87

Slika 6.6: Intenzivnost internacionalizacije nastajajočih in novih podjetnikov po skupinah držav

Slika 6.7: Intenzivnost internacionalizacije (v evropskih državah GEM) .88

Slika 6.8: Delež podjetnikov, ki dosegajo vsaj nacionalni oziroma vsaj globalni razpon, in sicer hkrati z vidika trga in novih izdelkov, storitev ali procesov, v celotni populaciji po skupinah držav

Slika 6.9: Delež podjetnikov, ki dosegajo vsaj nacionalno raven, in sicer hkrati z vidika trga in novih izdelkov, storitev ali procesov, v celotni populaciji (v evropskih državah GEM).

Slika 6.10: Delež podjetnikov, ki dosegajo vsaj globalno raven, in sicer hkrati z vidika trga in novih izdelkov, storitev ali procesov, v celotni populaciji ( $v$ evropskih državah GEM)..... 
Slika 6.11: Delež podjetnikov, ki dosegajo vsaj nacionalno ali vsaj globalno raven, in sicer hkrati z vidika trga in novih izdelkov, storitev ali procesov, v celotni populaciji (v evropskih državah GEM) 91

Slika 7.1: $\quad$ Oblike družinskega podjetništva v GEM ...............................................................................94

Slika 7.2: $\quad$ Obseg družinskega podjetništva v zgodnji podjetniški aktivnosti ..................................95

Slika 7.3: Delež slovenskih družinskih podjetij v zgodnji in ustaljeni podjetniški aktivnosti ........96

Slika 7.4: $\quad$ Obseg družinskega podjetništva v ustaljeni podjetniški aktivnosti................................97

Slika 7.5: $\quad$ Oblike in obseg družinskega podjetništva v Sloveniji .......................................................98

Slika 8.1: Ključne značilnosti po okvirnih pogojih za podjetništvo v letu 2020 …..........................105

Slika 8.2: Povprečne ocene okvirnih pogojev za podjetništvo v Sloveniji primerjalno s povprečjem evropskih držav in vseh držav GEM 107

Slika 8.3: Ocene elementov vladnih politik v Sloveniji in evropskih državah (tehtano povprečje, 0 = zelo nezadovoljivo, 10 = zelo zadovoljivo) 108

Slika 8.4: Ocene elementov vladnih programov v Sloveniji in evropskih državah (tehtano povprečje, 0 = zelo nezadovoljivo, 10 = zelo zadovoljivo) 109

Slika 8.5: $\quad$ Ocene elementov poslovne in strokovne infrastrukture v Sloveniji in evropskih državah (tehtano povprečje, 0 = zelo nezadovoljivo, 10 = zelo zadovoljivo).

Slika 8.6: Ocene elementov kulturnih in družbenih norm v Sloveniji in evropskih državah (tehtano povprečje, 0 = zelo nezadovoljivo, 10 = zelo zadovoljivo) 112

Slika 8.7: Indeks NECI 2020 po državah. 114

Slika 8.8: Vrednosti indeksa NECI po skupinah držav. 115

Slika 8.9: Ocene elementov reaktivacije in ponovne oživitve gospodarstva zaradi pandemije covida-19 v Sloveniji in evropskih državah (tehtano povprečje, 0 = zelo nezadovoljivo, 10 = zelo zadovoljivo)

Slika 8.10: Ocene elementov vladnih ukrepov zaradi pandemije covida-19 v Sloveniji in evropskih državah (tehtano povprečje, 0 = zelo nezadovoljivo, 1 0 = zelo zadovoljivo) 118

Slika 8.11: Zaviralni in spodbujevalni dejavniki podjetništva v Sloveniji 120 


\section{Kazalo tabel}

Tabela 1.1: Države GEM glede na regijo in stopnjo razvitosti, GEM 2020, APS ...................................26

Tabela 1.2: Značilnosti uteženega in neuteženega vzorca, GEM Slovenija 2020, APS .......................32

Tabela 1.3: Število anketiranih oseb v vzorcih sodelujočih državah po tipih gospodarstva, GEM 2020, APS

Tabela 1.4: Število sodelujočih nacionalnih izvedencev v sodelujočih državah po tipih gospodarstva, GEM 2020, NES

Tabela 2.1: GEM-ova preglednica značilnosti podjetništva v Sloveniji, GEM Slovenija 2020, APS 39

Tabela 3.1: Elementi podjetniške zmogljivosti, GEM Slovenija 2020, APS 43

Tabela 3.2: Elementi zaznavanja družbenih vrednot o podjetništvu v družbi, GEM Slovenija 2020, APS

Tabela 4.1: Pregled podjetniške aktivnosti med odraslim prebivalstvom po posameznih fazah in po skupinah držav, GEM Slovenija 2020, APS .59

Tabela 4.2: Razmerje med nastajajočimi in novimi podjetniki ter indeks smrtnosti v Sloveniji v letih od 2011 do 2020, GEM Slovenija 2020, APS

Tabela 4.3: Motivi nastajajočih in novih podjetnikov (v evropskih državah GEM), GEM Slovenija 2020, APS .64

Tabela 4.4: Ključne značilnosti motivov za podjetništvo v celotni zgodnji podjetniški aktivnosti, GEM Slovenija 2020, APS.

Tabela 4.5: Podjetniška aktivnost zaposlenih v Sloveniji v letih od 2011 do 2020, GEM Slovenija 2020, APS .70

Tabela 4.6: Razlogi za izstop podjetnika po skupinah držav, GEM Slovenija 2020, APS .73

Tabela 5.1: Odstotek nastajajočih in novih podjetnikov po starostnih razredih in skupinah držav, GEM Slovenija 2020, APS .78

Tabela 5.2: Odstotek ustaljenih podjetnikov po starostnih razredih in skupinah držav, GEM Slovenija 2020, APS. .78

Tabela 5.3: Odstotek nastajajočih in novih podjetnic med vsemi podjetniki v obdobju 2016-2020, GEM Slovenija 2020, APS

Tabela 5.4: Odstotek ustaljenih podjetnic med vsemi podjetniki v obdobju 2016-2020, GEM Slovenija 2020, APS .85

Tabela 6.1: Ambicioznost podjetnikov po skupinah držav, GEM Slovenija 2020, APS .93

Tabela 6.2: Načrti podjetnikov o zaposlovanju po skupinah držav, GEM Slovenija 2020, APS ........95

Tabela 7.1: Inovativnost družinskih in nedružinskih podjetij, GEM Family Business 2018, APS ....110

Tabela 7.2: Kazalnik inovativnosti v družinskih in nedružinskih podjetjih, GEM Family Business 2018, APS

Tabela 8.1: Priporočila izvedencev za izboljšanje podjetništva v Sloveniji po izbranih okvirnih pogojih, GEM Slovenija 2020, NES 


\section{Uvodni povzetek}

\section{Predstavitev Globalnega podjetniškega monitorja}

Globalni podjetniški monitor (GEM), največja svetovna longitudinalna raziskava podjetništva, raziskuje podjetniške fenomene že 22 let. Pod vodstvom London Business School in ameriškega Babson Collegea je bila ob sodelovanju desetih držav izvedena prva raziskava zgodnjega podjetništva. Slovenski raziskovalni tim z Inštituta za podjetništvo in management malih podjetij na Ekonomsko-poslovni fakulteti Univerze v Mariboru se je globalni raziskavi pridružil leta 2001 in naslednje leto izpeljal prvo raziskavo, ki je v to svetovno raziskovanje podjetništva vključila tudi Slovenijo. Od takrat sodelujemo v vseh letnih ciklih, tako da imamo za preteklih 19 let zanesljive podatke, s pomočjo katerih lahko pomembne elemente podjetništva v Sloveniji, še zlasti v njegovih začetnih fazah, primerjamo s podjetništvom v drugih državah, ki sodelujejo ali so sodelovale $v$ GEM. S poznavanjem, kam se $v$ globalnem merilu umešča podjetništvo $\vee$ Sloveniji, lahko ponudimo relevantne informacije za nosilce podjetniške politike pri njihovem oblikovanju ukrepov za spodbujanje kakovostnega podjetništva.

Globalnost, longitudinalnost in enotna metodologija, ki jo morajo sodelujoče države brezkompromisno uporabljati, so velike prednosti GEM pred ostalimi raziskavami podjetništva. Te prednosti namreč zagotavljajo, da so pridobljeni podatki zanesljivi in jih je zato možno verodostojno uporabljati in tolmačiti. Tako lahko dobimo jasno sliko o stanju in razvoju podjetništva v državi, kar je še posebej pomembno za oblikovalce ukrepov podjetniške politike pri reševanju nekaterih velikih izzivov za družbo, kot so cilji trajnostnega razvoja Združenih narodov (SDG), ali pri iskanju rešitev in odpravljanju posledic, ki jih povzroča pandemija koronavirusa SARS-CoV-2. Vedno bolj bodo namreč potrebni trdni, zanesljivi in verodostojni podatki za sprejemanje ključnih odločitev, ki spodbujajo trajnostne oblike podjetništva in zdrave podjetniške ekosisteme po vsem svetu. K takim prizadevanjem je v 22 letih obstoja GEM že večkrat prispeval. Nazadnje s posebno publikacijo Diagnosing COVID-19 Impacts on Entrepreneurship: Exploring policy remedies for recovery (ur. Aileen Ionescu-Somers in Anna Tarnawa, 2020), v kateri so med drugim navedeni tudi konkretni primeri, kako so se posamezne 
države $v$ letu 2020 odzvale na trenutno pandemijo. To ni edina posebna publikacija, ki podrobneje proučuje katero izmed posebej perečih področij. Doslej je bilo dodatno proučeno žensko podjetništvo, podjetniško izobraževanje, v razvoj usmerjeno podjetništvo, podjetništvo $\checkmark$ organizacijah, podjetništvo mladih in starejših, pregled podjetniških politik in primeri dobrih praks te politike.

GEM razpolaga z 22-letno serijo podatkov iz 115 gospodarstev na vseh celinah sveta, kar omogoča longitudinalno analizo držav ali skupine držav na različnih ravneh. Podatki izhajajo iz vsakoletnega anketiranja med 160 do 200 tisoč odraslih posameznikov in iz intervjujev s strokovnjaki, vključno s podjetniki vseh starosti. Z analizami podatkov GEM je angažiranih okrog 500 strokovnjakov za raziskovanje podjetništva s približno 300 akademskih in raziskovalnih ustanov. Tolikšen raziskovalni potencial je poleg poglobljenih letnih raziskav ustvaril tudi skoraj 1000 znanstvenih člankov ali poglavij v monografijah, v katerih so uporabljeni podatki, zbrani v okviru globalnega raziskovalnega programa GEM. V raziskovalnem ciklusu 2020 je bilo kljub pandemiji v raziskavo odrasle populacije vključenih 43 držav na različnih stopnjah gospodarske razvitosti.

Upoštevanje gospodarske razvitosti držav je pomembno, saj ta vpliva tako na razvitost podjetniškega okolja, $v$ katerem poteka podjetniški proces, kot tudi na celoten podjetniški ekosistem in njegove posamezne komponente, kot so odnos do podjetništva, dostopnost kapitala, ustreznost poslovne infrastrukture ali vodenje podjetniške politike. Velike gospodarske, kulturne, politične in demografske razlike med državami terjajo tudi drugačne ukrepe za spodbujanje podjetništva, ki so prilagojeni razvojni stopnji posamezne države. Pri nizkodohodkovnih državah gre predvsem za čim boljšo izkoriščenost obstoječih temeljnih proizvodnih dejavnikov ter vzpostavitev ustrezne infrastrukture, še zlasti izobraževalne, saj je v teh državah delovna sila še v sorazmerno velikem deležu nekvalificirana, kar omejuje nastajanje prodornih podjetij in njihovo rast. $V$ manj razvitih državah so zaradi nizke zaposlitvene moči obstoječih podjetij in manjšega števila večjih podjetij podjetni posamezniki prisiljeni $\vee$ tako imenovano samozaposlitveno preživetveno podjetništvo, ki je ob odsotnosti delovnih mest pogosto edina možnost za dostojno preživetje. Večina podjetniških priložnosti, ki jih ta tip podjetništva izkorišča, žal nima tolikšnega prihodkovnega potenciala, da bi omogočal tudi večje zaposlovanje in rast. Z rastjo družbenega proizvoda se postopoma spreminjajo tudi relevantni dejavniki, ki omogočajo podjetništvo in vplivajo nanj, obenem pa narašča tudi število podjetij, ki so sposobna zaposlovati.

Slovenija po svoji ekonomski moči spada v visokodohodkovna gospodarstva s stabilnim gospodarskim sistemom, ustrezno razvito infrastrukturo in relativno dobro urejenim poslovnim okoljem. Da bi lahko izboljšali podjetniški sistem in pospeševali kakovostno, $v$ razvoj in rast usmerjeno podjetništvo, se moramo primerjati s podobnimi državami, še zlasti pa s tistimi, ki imajo posamezna področja bolje urejena kot Slovenija. GEM pri tem zagotavlja zanesljivo podatkovno in vsebinsko podlago za razmisleke, potrebne pri snovanju primernega podjetniškega okolja in ustrezne podjetniške politike, ki podpira kakovostno podjetništvo. Zato ga tudi posamezne države obilno uporabljajo pri iskanju najboljših ukrepov, ki lahko odpravijo pomanjkljivosti v podjetniškem okolju.

V konceptualnem modelu GEM se v celoti odraža dejstvo, da je osrednji dejavnik podjetniške aktivnosti posameznik, njegovi motivi, nagnjenja in dejanja pa so vselej $v$ tesni interakciji z njegovim kulturnim, družbenim in gospodarskim okoljem. To pomembno vpliva na posameznikov odnos do razpoznavanja in izkoriščanja podjetniških priložnosti. Zato se $v$ raziskovanju ni mogoče izogniti podjetniškim ambicijam, inovativnosti in podjetnosti, pa tudi ne strahovom, razlogom in omejitvam, ki preprečujejo, da bi se usposobljenii posamezniki usmerili 
$\checkmark$ podjetništvo. Raziskovanje posameznikov je pomembno tudi zato, ker s tem zajamemo informacije, ki jih iz obstoječih statističnih in drugih podatkovnih virov ni mogoče pridobiti ali pa so ti viri povsem neprimerljivi med tolikim državami, kot jih zajame GEM. Velika neusklajenost in raznolikost teh virov med državami, pogosto pa tudi neprimerljivost posameznih podatkovnih baz, zahtevajo zato drugačen pristop. Med drugim tudi zato, ker za številne značilnosti, ki jih ugotavlja GEM, takšnih baz sploh ni. GEM namreč zajame tudi odnos posameznika in družbe do podjetništva, njegove ambicije in usposobljenost za podjetništvo, pa tudi posameznike $v$ vseh fazah podjetniškega procesa, od začetnih razmislekov, da bi se podali na podjetniško pot, do ustanovitve podjetja, poslovanja, rasti in prenehanja poslovanja. Zajame pa tudi notranje podjetništvo in posamezne bolj poglobljene teme, kot so recimo gig ekonomija, vpliv pandemije covida-19 ali sledenje ciljem trajnostnega razvoja. To je omogočeno z ustreznimi merami, ki so bile razvite, da omogočajo usklajeno pridobivanje podatkov ter harmonizacijo podatkov in dobljenih rezultatov, da se lahko države primerjajo med seboj.

Uporabljene mere temeljijo na konceptualnem okviru GEM in so zgoščene na stanje v podjetniškem ekosistemu, družbene vrednote in dojemanje podjetništva, individualne značilnosti potencialnega podjetnika, posamezne faze podjetniške aktivnosti in na podjetniške aspiracije. Družbeni, kulturni, politični in ekonomski kontekst, ki upošteva stopnjo razvitosti posameznega nacionalnega gospodarstva in razvitost ključnih podjetniških pogojev, ocenjujemo s pomočjo strokovnih mnenj skrbno izbranih izvedencev, ki imajo dober vpogled $\checkmark$ različne segmente podjetniškega procesa. Družbene vrednote in dojemanje podjetništva spoznavamo na temelju anketiranja odrasle populacije in njenih odgovorov o tem, ali družba sprejema podjetništvo kot dobro karierno izbiro, ali imajo podjetniki visok družbeni status ter kolikšno pozornost posvečajo podjetništvu mediji in s tem prispevajo k razvoju podjetniške kulture. S pomočjo odgovorov na ta vprašanja lahko bolje sklepamo o pomenu posameznih dejavnikov, ki lahko vplivajo na to, ali se bo posameznik odločil za podjetniško pot ali ne. Individualne značilnosti dejanskih podjetnikov in posameznikov imajo pomemben vpliv na podjetniški proces, še posebej v njegovih najzgodnejših fazah. Spoznavamo jih s pomočjo nekaterih demografskih in psiholoških dejavnikov ter motivacijskih vidikov. Z anketiranjem odrasle populacije dobimo tudi informacije o fazah življenjskega cikla podjema, na osnovi katerih se tvori eden temeljnih kazalnikov GEM, to je celotna zgodnjepodjetniška aktivnost TEA (ang. total early-stage entrepreneurial activity).

\section{Podjetniška zmogljivost odraslega prebivalstva in zaznavanje odnosa do podjetništva v družbi}

Na oblikovanje podjetniških namer in vključevanje posameznikov v podjetništvo vplivajo po eni strani posameznikove lastnosti in njegove zaznave lastnih sposobnosti in podjetniških kompetenc, po drugi strani pa tudi posameznikove zaznave okolja, v katerem namerava svoj podjem izvesti. V okviru raziskave GEM identificiramo zaznave ljudi o tem, ali obstajajo dobre priložnosti za začetek novega podjetja v lokalnem okolju in ali (ter v kakšnem obsegu) se posamezniki vidijo kot potencialni podjetniki. Da bi to ocenili, analiziramo, ali se anketiranci strinjajo, da imajo osebno znanje, spretnosti in izkušnje za začetek novega podjetja, in ali bi jih od ustanovitve novega podjetja oziroma podjema odvrnil strah, da to ne bi uspelo. Ker so posamezniki vselej tudi del širšega kulturnega in družbenega okolja, ki vpliva na njihove podjetniške namere in podjetniške odločitve, proučujemo tudi zaznavanje družbenih vrednot o podjetništvu. 
$\checkmark$ letu 2020 je Sloveniji zaznavalo obetavne poslovne priložnosti v svojem okolju v povprečju 42,03 odstotka ljudi, kar je dobrih 5 \% manj kot leto poprej. Še vedno pa to pomeni, da se je zaznavanje poslovnih priložnosti v zadnjih petih letih v Sloveniji v povprečju podvojilo (20,5\% $\checkmark$ letu 2015). Slovenija se je na lestvici 18 sodelujočih evropskih držav v raziskavi GEM po tem kazalniku v letu 2020 uvrstila na sredino lestvice in nad letošnje evropsko povprečje, ki znaša 39,52 \%. Čeravno je padlo zaznavanje podjetniških priložnosti, pa v povprečju več kot polovica (62 \%) posameznikov meni, da je v Sloveniji enostavno ustanoviti podjetje. Najvišje stopnje pri zaznavanju enostavnosti pri ustanovitvi podjetja in hkrati tudi najvišje stopnje zaznavanja poslovnih priložnosti so na Švedskem, v Italiji, na Norveškem in na Nizozemskem, najnižje pa v Španiji.

Na zaznavanje priložnosti in njihovo identificiranje kot obetavnih za podjetništvo ima pomemben vpliv tudi samozaznavanje lastnih podjetniških kompetenc, ki so povezane s tem, ali posameznik meni, da ima potrebno znanje, izkušnje in sposobnosti za podjetništvo. Po tej značilnosti se je prebivalstvo Slovenije v evropskem merilu vedno uvrščalo visoko. Tako je bilo tudi v letu 2020, ko ocenjujemo, da je ta odstotek enak 59,40 \%, kar je nekoliko več kot leta poprej in je tudi nad povprečjem evropskih držav, ki je v letu 2020 znašalo 52,64 \%. Na najvišja mesta na lestvici so se med evropskimi državami povzpele Hrvaška, Italija in Poljska, vse tri z več kot 60 \% prebivalstva, ki meni, da poseduje te podjetniške zmogljivosti. Slovenija se na evropski lestvici tako umešča na četrto mesto.

Strah pred neuspehom je sicer vselej ena od komponent podjetniškega delovanja, vendar pa je njegov vpliv v zgodnjih fazah podjetniške aktivnosti lahko pomembnejši kot takrat, ko obstaja kot sestavni del podjetniške prakse. V Sloveniji je bil v letu 2020 strah pred neuspehom med ljudmi prisoten v povprečju v nekoliko večji meri (48,22 \%) kot v letu 2019 (43,71 \%). Razkorak med razpoznavanjem poslovnih priložnosti in strahom pred neuspehom je v nekaterih državah velik, največji v Španiji, kjer je delež prebivalstva, ki zaznava poslovne priložnosti, najmanjši med sodelujočimi evropskimi državami, hkrati pa je strah pred neuspehom med ljudmi močno zasidran. V Sloveniji je sicer razlika med obema deležema relativno majhna, a vendar je strah pred neuspehom prisoten $\vee$ večji meri kot zaznavanje obetavnih poslovnih priložnosti. Med evropskimi državami je sicer le pet takšnih, v katerih delež prebivalstva, ki zaznava poslovne priložnosti, presega delež tistih, ki jih strah pred neuspehom odvrača od ustanovitve lastnega podjetja, to so Švedska, Italija, Norveška, Nizozemska in Poljska.

Eden izmed pokazateljev bodočih podjetniških aktivnosti so podjetniške namere. V Sloveniji namerava v povprečju slabih $12 \%$ ljudi, ki še niso vključeni v nobeno obliko podjetniške aktivnosti, stopiti na podjetniško pot $v$ naslednjih treh letih. To uvršča Slovenijo nekoliko nad evropsko povprečje, ki znaša 10,65 \%. Na samem vrhu so sicer Hrvaška (24,27 \%), Ciper $(20,5 \%)$ in Latvija (17,2\%). Na drugem koncu evropske lestvice, med gospodarstvi, kjer je delež prebivalstva z izraženimi podjetniškimi namerami najmanjši, najdemo Italijo (4,51\%), Avstrijo (4,05 \%) in Poljsko (4,74 \%). V primerjavi z obdobjem 2017-2019, ko je bil delež namer večji od $16 \%$, se je ta delež zmanjšal, delno tudi zaradi pandemije. Več kot polovica prebivalcev (51,40\%) je $v$ povprečju menila, da ima pandemija vsaj majhen vpliv na podjetniške namere ljudi, da je ta vpliv velik, pa je menila več kot petina anketiranih (20,59 \%). Domnevamo lahko, da je to tudi eden izmed razlogov, zaradi katerih so se podjetniške namere ljudi v Sloveniji v povprečju zmanjšale. Da ima pandemija vsaj majhen vpliv na podjetniške namere ljudi, misli v povprečju 59,1 \% odraslega prebivalstva v Evropi. V obeh primerih je na vrhu lestvice Rusija, kjer celo več kot $90 \%$ prebivalstva v povprečju meni, da ima pandemija vsaj majhen vpliv na podjetniške namere, več kot 70 \% pa, da je ta vpliv velik. V obeh primerih Rusiji na lestvici sledijo Latvija, Velika Britanija in Luksemburg. Najmanjši zaznani vpliv pandemije izražajo na Norveškem. 
Po večini elementov podjetniške zmogljivosti se Slovenija uvršča nekoliko nad povprečje sodelujočih evropskih držav). Delež ljudi, ki vidijo poslovne priložnosti v svojem okolju, se je v Sloveniji v zadnjih petih letih podvojil, kar zagotovo kaže na krepitev podjetniških zmogljivosti prebivalstva. Res pa je tudi, da se naša država uvršča nad evropsko povprečje tudi glede na razširjeni strah pred podjetniškim neuspehom, vendar pa tudi precej nad evropsko povprečje glede na samozaznane podjetniške kompetence pri ljudeh. Samozavest in zaupanje $v$ sposobnost za uspeh sta zagotovo pozitivna pokazatelja pripravljenosti stopiti na podjetniško pot. Vpliv na to pa ima tudi splošen odnos družbe do podjetniškega delovanja.

Tudi v letu 2020 je v povprečju v evropskih državah skoraj 70 \% odraslega prebivalstva verjelo, da so uspešni podjetniki v družbi dobro sprejeti, da so spoštovani in uživajo velik ugled. Hkrati pa jih je v povprečju za skoraj 10 odstotnih točk manj menilo, da je podjetništvo ustrezna oziroma zaželena poklicna pot. $\vee$ povprečju je nekaj več kot 60 \% odraslih prebivalcev tudi menilo, da je uspešno podjetništvo deležno znatne medijske pozornosti. Slovenija se, podobno kot v preteklih letih, po vseh elementih uvršča visoko nad evropsko povprečje. Delež odraslega prebivalstva, ki meni, da so uspešni podjetniki v družbi dobro sprejeti, spoštovani in uživajo velik ugled, znaša v Sloveniji več kot 85 \%. Na lestvici sledita Nemčija z 81,82 \% in Avstrija z 79,76 \%. Na drugi strani lestvice najdemo Hrvaško (53,47 \%), Poljsko (60,14 \%) in Španijo (61,14 \%).

V Sloveniji je tudi porasel delež ljudi, ki menijo, da je podjetništvo dobra izbira kariere - s 63,5\% v letu 2019 na 68,67 \% v letu 2020. V evropskem merilu se Slovenija skupaj s še štirimi državami uvršča nad evropsko povprečje. Največji delež imajo Ciper (76,65 \%), Rusija (75,30 \%) in Velika Britanija (69,63 \%), na repu lestvice pa so Avstrija, Švica in Slovaška, kjer manj kot polovica ljudi meni, da je podjetništvo zaželena izbira kariere.

Interakcija med kulturnimi in družbenimi normami ter ravnijo podjetništva je zapletena in večplastna. Mediji lahko vplivajo na družbo na veliko različnih načinov, medijska podpora pa je eden od pomembnih podpornih mehanizmov pri spreminjanju kulturnih in družbenih norm v smeri sprejemanja in podpore podjetništvu v družbi. Veseli nas, da je tudi v letu 2020 odraslo prebivalstvo v Sloveniji zaznavalo veliko podporo podjetništvu v medijih. Kar 81,3 \% ljudi je menilo, da je v medijih v Sloveniji pogosto mogoče zaslediti zgodbe o uspešnih novih podjetnikih. Tako je Slovenija tudi v letu 2020 v samem vrhu lestvice sodelujočih evropskih držav, sledita ji Avstrija (70,03 \%) in Velika Britanija (69,21 \%). Na spodnji strani lestvice, z najnižjo zaznano medijsko podporo podjetništvu, so Poljska (41,02 \%), Španija (50,21 \%) in Nemčija (53,66 \%).

\section{Podjetniška aktivnost odraslega prebivalstva}

Podjetniški proces se od zaznavanja podjetniške priložnosti dalje razvija skozi večzaporednih faz, ki jo začenjajo potencialni podjetniki, tem sledijo nastajajoči podjetniki in nato novi podjetniki. Nastajajoči in novi podjetniki skupaj tvorijo celotno zgodnjo podjetniško aktivnost, eno izmed osnovnih mer raziskave GEM. Naslednjo fazo sestavljajo ustaljeni podjetniki, zadnjo fazo pa predstavlja izstop podjetnika iz posla. Potencialnih podjetnikov, to je tistih posameznikov, ki prepoznavajo poslovne priložnosti, sprejemajo tveganje in menijo, da imajo dovolj znanja in podjetniških sposobnosti, da uresničijo podjetniški podjem, je bilo leta 2020 v Sloveniji 13,3 \%, medtem ko jih je bilo v letu 2019 še 16,6 \% . Nastajajočih podjetnikov, ki so vključeni v nastajanje podjetja, ki je mlajše kot tri mesece, je bilo prav tako manj kot v letu 2019 (3,1 \% proti 4,4 \%). Manj je bilo tudi novih podjetnikov, to je tistih, ki imajo podjetje in izplačujejo plače več kot tri mesece, vendar ne več kot tri leta in pol. Teh je bilo lani 2,96 \%, leta 2019 pa 3,08 \%. V vseh fazah celotnega podjetniškega procesa je bil v letu 2020 delež tistih, ki so bili vključeni v podjetniško 
aktivnost, manjši v primerjavi z letom prej, kar bi lahko pripisali tudi spremenjenim pogojem $\checkmark$ poslovnem okolju $\vee$ zadnjem letu. Sklepno fazo podjetniškega procesa tvorijo ustaljeni podjetniki, to je posamezniki, ki imajo podjetje, staro več kot tri leta in pol. Čeravno je njihov posel praviloma bolj stabilen, z razvitimi proizvodi in razmeroma stalnimi odjemalci, je prišlo do upada tudi pri njih. Če smo lahko med ustaljene podjetnike leta 2019 uvrstili 8,5 \% odraslega prebivalstva, je v letu 2020 v Sloveniji ta delež upadel na 7,0 \%. Je pa v lanskem letu izstopilo iz posla manj podjetnikov (1,6 \%) kot leta 2019, ko je iz poslovanja izstopilo 1,9 \% podjetnikov, kar lahko pripišemo tudi veliki negotovosti v okolju, ki odvrača od sprejemanja potencialno tveganih odločitev.

Gre torej za precejšen upad celotne zgodnje podjetniške aktivnosti s 7,8 \% v letu 2019 na 6,0 \% v letu 2020, pri čemer velja pripomniti, da upad indeksa TEA zaznavamo tudi v drugih evropskih državah, medtem ko je na globalni ravni celotna zgodnja podjetniška aktivnost narasla. Primerjava Slovenije z evropskimi državami pokaže, da smo v evropskem merilu šele na 14. mestu med 18 državami. V povprečju je indeks TEA v evropskih državah znašal 8,1 \%. Najvišje stopnje zgodnje podjetniške aktivnosti so dosegle Latvija (15,6 \%), Slovaška (13,9 \%) in Hrvaška (12,7 \%), najnižje pa Italija (1,9\%), Poljska (3,1 \%) in Nemčija (4,8 \%). Razlike med posameznimi evropskimi državami so zelo velike. Glede na leto 2019 so se absolutne razlike med državama z najvišjo in najnižjo stopnjo celo povečale (Italija 2,8 \% in Latvija 15,4 \% v letu 2019).

Primerjava celotne zgodnje podjetniške aktivnosti v vseh državah GEM, v evropskih državah in $\checkmark$ Sloveniji pokaže, da se v razvitejših državah manj posameznikov odloči za podjetništvo. V teh državah je namreč na voljo dovolj drugih oblik pridobivanja dohodka, saj je več možnosti za zaposlovanje $v$ večjih podjetjih, ki vsrkajo posameznike, ki bi se sicer potencialno odločili za podjetniško aktivnost. $\vee$ manj razvitih državah ali državah z nižjimi dohodki je na voljo manj zaposlitev, zato so se posamezniki primorani podati v podjetništvo, četudi to ni njihova prva motivacija ali izbira. V vseh državah GEM je 2,4-krat več zgodnje podjetniške aktivnosti kot v Sloveniji, v evropskih državah pa 1,3-krat več.

Posamezniki se za podjetništvo odločijo iz različnih nagibov. V najrevnejših okoljih je prevladujoči motiv predvsem preživetje sebe in družine, drugod je lahko to predvsem sledenje zaznani poslovni priložnosti. V okviru raziskave GEM so bile v letu 2020 proučene naslednje skupine motivov: želja po ustvarjanju spremembe v svetu, želja po ustvarjanju premoženja oziroma večjega dohodka, želja po nadaljevanju družinskega podjetja oziroma tradicije ter potreba po preživetju, ker so službe redke. Da jih motivira želja po ustvarjanju sprememb v svetu, so v Evropi kot prevladujoč motiv navedli zgodnji podjetniki v Veliki Britaniji (57,6 \%) in Luksemburgu (51,1 \%). Najmanj zgodnjih podjetnikov pa je željo po ustvarjanju sprememb v svetu navedlo na Poljskem (22 \%), v Rusiji (24,2 \%) in Italiji (26,6 \%). V Sloveniji je bilo takih podjetnikov 44,6 \%.

Ustvarjanje premoženja oziroma povečevanje dohodka najbolj motivira zgodnje podjetnike $\vee$ Italiji (95,3 \%) in na Cipru (85,2 \%), najmanj pa jih je ta motiv navedlo na Norveškem (30,1 \%), v Švici (32,5\%) in Avstriji (33,4\%). V Sloveniji je bilo zgodnjih podjetnikov s tem ciljem 39,7 \%, kar je precej manj kot leto prej (47,1\%). Motiv nadaljevanja družinskega podjetja oziroma tradicije je zdaleč najbolj izražen v Nemčiji (62 \%), sledi ji Grčija (35,7 \%). V Sloveniji ta motiv navaja 21,6 \% zgodnjih podjetnikov, v Evropi pa najmanj na Norveškem (11,8\%), v Rusiji (16,5\%) in Luksemburgu (16,6 \%). Motiv preživetja, ker so službe redke, so največkrat izrazili zgodnji podjetniki v Italiji (82,2 \%), na Cipru (77,4 \%) in na Slovaškem (73,8 \%). Najmanj jih je ta motiv navedlo na Norveškem $(23,1 \%)$ in Švedskem (28,9\%). V Sloveniji je ta motiv za podjetništvo precej pogost, saj ga je navedlo $72,2 \%$ zgodnjih podjetnikov, kar je precej več kot leto poprej (60,1\%). Vendar pa tega motiva v razvitih državah, tudi v Sloveniji, ne moremo enačiti s splošnim pomanjkanjem služb ali odsotnostjo 
velikih podjetij, ki zagotavljajo delovna mesta, ampak predvsem s strukturnim neskladjem med povpraševanjem po delovnih mestih in njihovo ponudbo.

Kriza zaradi covida-19 je povzročila velike spremembe v podjetništvu, vendar te niso zmeraj negativne. Čeprav je številnim podjetjem prinesla težave v poslovanju, pa je za marsikaterega podjetnika pomenila tudi pojavljanje novih poslovnih priložnosti. V Sloveniji je $\vee$ času krize zaradi covida-19 kar 33 \% zgodnjih podjetnikov zaznalo nove poslovne priložnosti, kar je toliko kot v povprečju v evropskih državah. Tudi ko gledamo delež podjetnikov, ki so izstopili iz poslovanja zaradi krize, povzročene z epidemijo covida-19, to ni najpogostejši razlog. Navedlo ga je 12,1 \% podjetnikov, kar je bistveno manj kot v evropskih državah (20,1\%). Med razlogi prevladujejo prodaja, izkoriščanje druge priložnosti, upokojitev ali drugi osebni razlogi (65,2%), finančni razlogi (13,4\%), davčne in vladne politike ali birokracija (9,3\%). Da pandemijska kriza ni pomembneje vplivala na izstope iz poslovanja, je treba delno pripisati tudi nizu protikoronskih zakonov s finančnimi ukrepi za blažitev posledic pandemije, $v$ katerih je vrsta ukrepov namenjenih financiranju stroškov poslovanja podjetja in podjetnika, ki lahko preprečujejo odločitev podjetnika o izstopu ali pa izstop prestavljajo v prihodnost.

\section{Demografske značilnosti slovenskega podjetništva}

Zaradi krize, povzročene s covidom-19, se je v letu 2020 močno povečalo število prijavljenih brezposelnih, zmanjšalo povpraševanje po delavcih in zaposlovanje brezposelnih. Odrazilo pa se je tudi pri upadu tako zgodnje kot ustaljene podjetniške aktivnosti. VSloveniji sta najpogostejši starostni obdobji za ustanavljanje podjetij obdobji od 25. do 34. ter od 35. do 44. leta. V letu 2020 je bilo največ zgodnje podjetniške aktivnosti med mladimi v starosti od 25 do 34 let. Odstotek nastajajočih in novih podjetnikov je v Sloveniji znašal 37,49 \%, medtem ko je bil v vseh analiziranih državah GEM v povprečju 32,10 \% in v evropskih državah 30,25 \%. Porast zgodnje podjetniške aktivnosti te skupine mladih bi lahko pripisali njihovi ustreznejši pripravljenosti za izkoriščanje podjetniških priložnosti, povezanih z delom na daljavo, in ustreznejšo digitalno pripravljenostjo, ki je v času epidemije postala ključna konkurenčna prednost. Žal pa se je v tej starostni skupini močno zmanjšal delež žensk.

Zaznavamo precejšen zaostanek najmlajše starostne skupine (od 18 do 24 let), ki je v poprečju skoraj trikrat manj zgodaj podjetniško aktivna v primerjavi z vrstniki iz proučevanih skupin držav. Razlog gre najverjetneje pripisati množični vključenosti mladih $v$ srednješolsko in terciarno izobraževanje v Sloveniji. Zelo je upadla tudi zgodnja podjetniška aktivnost starostne skupine od 45 do 54 let (s 25,6\% na 14,11\%). Upad je na prvi pogled presenetljiv, saj gre za posameznike v zrelem obdobju kariere, ki imajo ustrezna znanja in veščine, z leti pa so si že ustvarili potrebne mreže povezav za potencialno uspešno samostojno podjetniško pot. Ocenjujemo, da je močan razlog za tako izrazit upad zgodnje podjetniške aktivnosti v skupini, ki je sicer potencialno zelo obetavna, po eni strani v višjih oportunitetnih stroških zaradi splošne negotovosti, po drugi strani pa v težnji po izkoriščanju varnega zavetja v obstoječih zaposlitvah ter pomoči državnih intervencij v času krize. Proučevanje ustaljene podjetniške aktivnosti v Sloveniji pa pokaže bolj spodbudno sliko. Kljub pandemiji se je kot najaktivnejša izkazala starostna skupina od 34 do 44 let (njihov delež se je povečal z 22,6 \% v letu 2019 na 36,52 \% v letu 2020). Tudi starejše skupine ustaljenih podjetnikov so bile zelo aktivne, kar kaže na večjo preživetveno moč izkušenih ustaljenih podjetnikov. Ti se ob pojavu pandemije z izrednimi razmerami večinoma niso srečevali prvič v svoji karieri, pač pa so lahko s pridom izkoristili svoje akumulirano znanje, kredibilnost in izkušnje iz preteklih zaostrenih poslovnih situacij. 
Med starostnimi skupinami se motivi za ustanovitev podjetja precej razlikujejo. Pri najmlajših zgodnjih podjetnikih je najbolj izražen preživetveni motiv, kar lahko odraža težave pri iskanju primerne službe za tiste z manj izkušnjami. S starostjo se pogostost tega motiva zmanjšuje, v starostnih skupinah od 45 let naprej pa povečuje, kar verjetno odraža tveganje izgube službe in morebiti tudi v družbi še vedno prisotno starostno pristranskost. Nadaljevanje družinske tradicije postaja pomembnejše v starejših starostnih skupinah, zlasti v starosti od 45 do 54 let. Zgodnje podjetnike v srednjih letih približno uravnoteženo spodbujajo k podjetniškemu udejstvovanju vsi štirje proučevani motivi, čeravno s starostjo narašča težnja po ustvarjanju premoženja oziroma povečevanju dohodka, želja po spreminjanju sveta pa upada.

Delež zgodnjih podjetnikov, mlajših od 34 let, je od 17,4 \% v letu 2019 upadel na 15 \% v letu 2020 zlasti zaradi izrazitega padca deleža nastajajočih podjetnikov. Zmanjšanje podjetniške aktivnosti mlajših pripisujemo padcu povpraševanja in veliki negotovosti v pandemskem letu 2020. Je pa dobra novica, da se je v Sloveniji tudi lani že tretje leto zapored povečala zgodnja podjetniška aktivnost žensk. V letih od 2018 do 2020 se je povečala za skoraj 10 odstotnih točk, na 38,3\%, in tako prvič v opazovanem obdobju presegla evropsko povprečje (38,1 \%). Ta rezultat je presenetljiv, saj kaže, da je padec ekonomske aktivnosti v času pandemije, ki je na trgu dela izraziteje prizadela ženske, posledično prispevala k intenzivnejšemu ustanavljanju podjetij s strani žensk. Primerjava Slovenije z evropskimi državami GEM glede zgodnje podjetniške aktivnosti med spoloma kaže, da se je v letu 2020 Slovenija uvrstila na 9. mesto med 18 proučevanimi državami in tako znatno izboljšala svoj položaj na evropski letvici v primerjavi z letom 2019 (ko je zasedla 18. mesto med 21 evropskimi državami). Največjo participacijo žensk v zgodnji podjetniški aktivnosti v letu 2020 sta sicer izkazovali Švica (47,21 \%) in Nemčija (46,51 \%), najmanjšo pa Italija (23,97 \%) in Luksemburg (31,26 \%). Povečanje deleža žensk $v$ zgodnji podjetniški aktivnosti ima za posledico ugodnejše primerjalno razmerje med spoloma. Na vsakih 10 podjetnikov je v Sloveniji 6,21 nastajajoče in nove podjetnice. Vrzel med spoloma se tako postopoma zmanjšuje in v lanskem letu je zgodnja podjetniška aktivnost žensk v najmlajši in najstarejši starostni skupini celo presegla zgodnjo podjetniško aktivnost moških.

Kar se tiče dohodkovne ravni nastajajočih in novih podjetnikov, ugotavljamo, da se je za več kot 6 odstotnih točk povečal delež ustanoviteljev podjetij z najnižje dohodkovne ravni. Podatek je skladen z najpogosteje ugotovljenim motivom za zgodnjo podjetniško aktivnost med Slovenci, ki je bil v letu 2020 pretežno preživetveni motiv, in tudi z odgovori slovenskih podjetnikov, ki so v 44,7 \% primerih v letu krize zaradi covida-19 navajali padec družinskih dohodkov. Med ustaljenimi podjetniki se je $v$ največji meri povečal delež tistih s srednje dohodkovne ravni (s 30,9 \% v letu 2019 na 40,6 \% v letu 2020), kar lahko pripišemo padcu gospodarske aktivnosti in zaslužka med tistimi z najvišje dohodkovne ravni in slabši izrabi potenciala obetavnih priložnosti med ustaljenimi podjetniki z najnižje dohodkovne ravni, ki so lahko v manjši meri izkoristili krizne razmere v svoj prid.

Primerjava izobrazbene strukture zgodnjih in ustaljenih podjetnikov in nepodjetnikov za leto 2020 je pokazala, da je bilo med nastajajočimi in novimi podjetniki največ takšnih z visokošolsko, univerzitetno ali višjo izobrazbo (38,5 \%). Ustaljeni podjetniki imajo prevladujočo srednješolsko izobrazbo (42,2 \%), med nepodjetniki pa izkazujeta skoraj enak delež srednješolska (35,5 \%) in visokošolska, univerzitetna ali višja izobrazba (35,8 \%). Poznavanje izobrazbene strukture je pomembno, saj je z njo povezana tudi aspiracijska raven nastajajočih in novih podjetnikov. 


\section{Podjetniške aspiracije}

Ustanavljanje in še posebej uspešna rast inovativnih in ambicioznih podjetij je zahtevna in povezana z velikimi tveganji, zato so taka podjetja žal zelo redka. Tudi zato, ker zahtevajo obilo znanja, usposobljenosti in velikih aspiracij podjetnikov, ki jih vodijo. Ugotavljamo, da ambicioznost slovenskih nastajajočih in novih podjetnikov negativno odstopa od pričakovanj kolegov iz preostalih skupin držav. Čeravno so v primerjavi z letom 2019 aspiracije zgodnjih podjetnikov iz Slovenije porasle s slabih $15 \%$ na 16,8 \%, pa v povprečju države iz visokohodkovnih gospodarstev izkazujejo opazno višjo stopnjo ambicioznosti, saj je znotraj TEA dobrih 21 \% takšnih, ki pričakujejo, da bo njihovo podjetje ustvarilo 10 ali več delovnih mest v petih letih od zagona podjetja. Še večje relativne razlike med Slovenijo in proučevanimi skupinami držav po ambicioznosti podjetnikov zasledimo pri še bolj ambiciozno zastavljenem cilju, da bi ustvarili 19 ali več novih delovnih mest v petih letih. Če je v Sloveniji 0,60\% anketirancev na ravni celotne populacije prepričanih, da lahko v petih letih ustvarijo 19 ali več delovnih mest, je ta delež v državah GEM in visokodohodkovnih gospodarstvih več kot trikrat večji. V primerjavi s skupino evropskih držav (0,87 \%) je zaostanek precej manjši.

Med evropskimi nastajajočimi in novimi podjetniki dobrih $25 \%$ pričakuje, da bodo čez pet let ustvarili več kot pet delovnih mest. V Sloveniji je bil ta delež v letu 2020 nekoliko večji (30%). Največji deležambicioznih podjetnikov med evropskimi državami so leta 2020 izkazovali Rusija (50\%), Ciper (45 \%), Luksemburg (38 \%), Norveška in Latvija (32\%). Najmanj ambicioznosti glede števila zaposlenih čez pet let pa so v skupini evropskih držav izražali nastajajoči in novi podjetniki v Avstriji (3 \%), Švici (12\%), Španiji (14 \%), na Nizozemskem (15\%) in v Grčiji (17\%). Imamo pa v Sloveniji velik delež podjetij, ki niso zaposlovalci in tudi ne načrtujejo postati dejanski zaposlovalci. Medtem ko v Sloveniji ustvarja ali načrtuje ustvariti delovna mesta 4,95 \% podjetnikov, je ta delež v državah GEM 11,50 \%, v državah z visokodohodkovnim gospodarstvom 9,98 \% in v evropskih državah 5,79 \%. To verjetno pojasnjuje tudi zaznano večje število zaprtih podjetij v času pandemije v letu 2020, saj je podjetja z nič zaposlenimi bistveno laže zapreti kot podjetja z zaposlenimi. Največji delež odraslih prebivalcev, ki že ustvarjajo delovna mesta ali verjamejo, da jih bodo ustvarjali v naslednjih petih letih, je $v$ Latviji (11,75 \%), na Slovaškem (9,39 \%), Hrvaškem (8,3 \%) in na Cipru (8,09 \%), najmanjši delež pa v Italiji (1,17\%).

Podjetniške rasti praviloma ni mogoče dosegati na majhnem lokalnem ali nacionalnem tržišču, zato je za slovenska ambiciozna podjetja pomembno, da so močno odprta $v$ mednarodni prostor. $V$ raziskavi GEM stopnjo mednarodnosti poslovanja podjetij ter stopnjo njihove inovativnosti in konkurenčnosti ugotavljamo s pomočjo razpona ciljnega trga (lokalno, nacionalno, globalno), za kateri trg so izdelki ali uporabljena tehnologija zares novi. Primerjava Slovenije s posameznimi skupinami držav je pokazala, da so slovenska nastajajoča in nova podjetja nadpovprečno osredotočena na kupce v globalnem okolju. Slaba polovica slovenskih nastajajočih in novih podjetnikov poroča, da imajo kupce tudi na globalni ravni (46\% podjetij), pri čemer je v drugih skupinah držav ta delež precej manjši: v državah GEM $23 \%$, v skupini visokodohodkovnih gospodarstev $29 \%$ in v evropskih državah $33 \%$. To samo potrjuje dosedanje ugotovitve raziskav, da so slovenski podjetniki že tradicionalno zelo mednarodno usmerjeni, $k$ čemur jih sili majhnost slovenskega trga. Določena inovacijsko gnana slovenska podjetja tako na slovenskem trgu sploh ne ustvarjajo omembe vrednega obsega poslovanja, ampak so skoraj v celoti usmerjena na mednarodne trge. S tako velikim deležem se je Slovenija v evropskem merilu uvrstila daleč nad povprečje držav, vključenih v raziskavo GEM. O večjem deležu poročajo le podjetniki iz Luksemburga (59\%). Velik delež 
imajo še ciprska (45\%), grška (42\%) in latvijska podjetja (41\%), o najmanjšem deležu globalnih kupcev pa poročajo podjetniki s Poljske (2 \%), iz Italije (10 \%) in Španije (23 \%).

Tudi delež nastajajočih in novih podjetij, ki menijo, da je več kot 25 \% kupcev njihovih izdelkov ali storitev iz tujine, je v Sloveniji večji kot v posameznih skupinah držav, vključenih v raziskavo GEM. Takšnih podjetij je bilo v letu 2020 v Sloveniji 21 \%, v državah GEM 10 \%, v visokodohodkovnih državah $13 \%$ in v evropskih državah $16 \%$. V sodelujočih evropskih državah so bile najvišje stopnje internacionalizacije (več kot $25 \%$ kupcev v tujini) med nastajajočimi in novimi podjetniki izmerjene v Luksemburgu (30 \%), na Cipru (30 \%) in na Hrvaškem (25\%), najnižje pa na Poljskem (1\%), v Italiji (5\%) in Španiji (6\%).

Inovacijsko gnana podjetja s potencialom za rast, ki jih vodijo ambiciozni podjetniki, so ključni vir ustvarjanja kakovostnih delovnih mest z visoko dodano vrednostjo. Podjetnikova inovacijska naravnanost igra pomembno vlogo pri določanju stopnje inovacijske moči podjetja, ki je prav tako odvisna od vpetosti podjetja $\vee$ medpodjetniške in raziskovalne mreže, razvojnega sodelovanja s kupci in dobavitelji, pa tudi od inoviranju naklonjenega poslovnega okolja. Delež posameznikov med odraslimi prebivalci Slovenije, katerih podjetja dosegajo vsaj nacionalno raven trga in so hkrati tudi njihovi izdelki, storitve ali procesi novost na vsaj nacionalnem trgu, je znašal 1,06 \%, kar je zelo podobno deležem v proučevanih skupinah držav. Ko Slovenijo primerjamo z drugimi evropskimi državami, vključenimi v raziskavo GEM, se uvrščamo pod povprečje evropskih držav. Največji delež posameznikov med odraslimi prebivalci, katerih podjetja dosegajo nacionalno raven po obeh kriterijih, je na Slovaškem (2,91 \%), najmanjši pa na Poljskem (0,42 \%) in v Španiji (0,44 \%). Delež podjetnikov med odraslim prebivalstvom $\checkmark$ evropskih državah, vključenih $v$ raziskavo GEM, ki s svojimi proizvodi dosegajo skupaj vsaj nacionalni ali vsaj internacionalni trg, hkrati pa so njihovi izdelki, storitve in procesi novi vsaj na nacionalni ali na internacionalni ravni, je leta 2020 za Slovenijo znašal 1,54 \%, s čimer se naša država uvršča v spodnjo polovico evropskih držav, vključenih v raziskavo GEM. Največji delež posameznikov med odraslimi prebivalci, katerih podjetja dosegajo ali nacionalno ali internacionalno raven po obeh kriterijih, je na Slovaškem (4,12 \%) in na Nizozemskem (3,57 \%), najmanjši pa na Poljskem (0,43 \%) in v Španiji (0,58 \%).

V raziskavi GEM pa je bilo tudi ugotovljeno, da je delež podjetnikov med odraslim prebivalstvom $\checkmark$ evropskih državah, vključenih $\vee$ raziskavo GEM, ki s svojimi proizvodi dosegajo vsaj internacionalni trg, hkrati pa so njihovi izdelki, storitve in procesi novi vsaj na internacionalni ravni, leta 2020 za Slovenijo znašal 0,48 \%. S tem se Slovenija uvršča v povprečje evropskih držav, vključenih v raziskavo GEM. Največji delež posameznikov med odraslimi prebivalci, katerih podjetja dosegajo internacionalno raven po obeh kriterijih, je sicer na Slovaškem (1,21\%), najmanjši pa na Poljskem (0,01\%) in v Italiji (0,02\%).

V Sloveniji se počasi krepi zavedanje o pomenu inovacijsko gnanih podjetij, ki jih ustanavljajo in vodijo ambiciozni podjetniki. Deloma so k temu prispevali uspehi in merljivi učinki podjetij, deloma različne študije, kot je tudi raziskava GEM. Večje zavedanje izvajalcev vladnih politik je privedlo tudi do povečanega vlaganja energije in naporov, usmerjenih v podporo podjetjem pri zagotavljanju različnih virov, pa tudi v ustvarjanje ugodnejših okvirnih pogojev za poslovanje podjetij. Stem se krepijo pogoji za aktivacijo razpoložljivega podjetniškega talenta in privabljanje novega. 


\section{Družinska podjetja}

Krepi se tudi zavedanje o pomenu družinskih podjetij. Zato smo v letošnji raziskavi GEM del naše pozornosti namenili tudi temu področju, saj je med nastajajočimi in novimi podjetji v Sloveniji kar $85 \%$ vseh podjetij družinskih. Med njimi prevladujejo tista, pri katerih družina sodeluje v vodenju, ne pa tudi v lastništvu podjetja - takih je 66,9\% vseh novonastajajočih podjetij. Pri pregledu zgodnje podjetniške aktivnosti po državah lahko ugotovimo, da v Vzhodni in Južni Aziji v bistvu celotna zgodnja podjetniška aktivnost vključuje (širšo) družino. Na Japonskem, Tajvanu in Kitajskem je delež družinskega podjetništva najmanjši - nekaj več kot 40 \% celotne zgodnje podjetniške aktivnosti. V Evropi in Severni Ameriki se vključenost družine v zgodnji podjetniški aktivnosti giblje od 54 \% v Turčiji do 90 \% na Poljskem.

Najpogostejša oblika družinskega podjetništva v zgodnji podjetniški aktivnosti je vodenje brez solastništva. Velik delež te oblike družinskega podjetništva, približno $85 \%$ ali več celotne zgodnje podjetniške aktivnosti družinskega podjetništva, prevladuje v štirih gospodarstvih iz različnih regij: Madagaskar, Panama, Indonezija in Poljska. Na drugi strani pa Kitajska poroča le o 12-odstotnem vodenju brez solastništva. Naslednja najpogostejša oblika družinskega podjetja je solastništvo z vodenjem. Ta oblika označuje več kot tretjino družinskih podjetnikov $\checkmark$ Kolumbiji, Urugvaju in Združenih arabskih emiratih, vendar manj kot $5 \%$ vse zgodnje podjetniške aktivnosti družinskega podjetništva v Republiki Koreji. Tako obliko družinskega podjetništva, da bi bili podjetniki, ki so člani družine, tudi solastniki, vendar ne bi sodelovali tudi v vodenju družinskega podjetja, pa srečamo le redko. V številnih gospodarstvih (Tajska, Portoriko, Bolgarija, Velika Britanija, Rusija, Ciper in Francija) te oblike ne prepoznavajo kot oblike družinskega podjetništva. Najvišjo stopnjo te oblike lahko opazimo v Argentini (18 \%). $\checkmark$ Sloveniji v 16,5 \% nastajajočih in novih podjetij družinskih podjetij sodelujejo družinski člani tako v lastništvu kot tudi v vodenju. Kar se tiče ustaljenih podjetij v Sloveniji, jih je večina družinskih (96,4 \%), najpogostejša oblika družinskega podjetništva, ki zajema skoraj tri četrtine vseh ustaljenih podjetij, pa je tista, pri kateri družinski člani sodelujejo v vodenju, ne pa tudi v lastništvu podjetja (72,3\%).

Zanimala nas je tudi inovativnost podjetij s tržnega vidika, s poudarkom na podjetnikovem dojemanju trga, s katerim se sooča, novosti uporabljene tehnologije (oziroma o namerah njene uporabe), novosti izdelka ali storitve za kupce ali potencialne kupce ter z vidika stopnje konkurence na trgu, na katerem deluje ali želi nanj vstopiti. Opažamo jasen vzorec razlik med družinskimi in nedružinskimi podjetji. Delež visoko inovativnih podjetij je v vseh geografskih regijah sveta za nedružinska podjetja večji kot za družinska. Razlika v korist nedružinskih podjetij v primerjavi z družinskimi je največja v evropskih državah, kjer delež visoko inovativnih nedružinskih podjetij presega delež družinskih podjetij za deset odstotnih točk; razlika je najmanjša v Južni in Vzhodni Aziji, kjer družinska podjetja zaostajajo za dve odstotni točki, medtem ko na Bližnjem vzhodu in v severni Afriki družinska podjetja glede na delež visoko inovativnih podjetij vodijo za odstotno točko v primerjavi z nedružinskimi podjetji. Slovenija se med družinskimi in nedružinskimi podjetji po kazalniku inovativnosti uvršča nad povprečje evropskih držav, a pod povprečje razvitih držav Severne Amerike in Azije, pa tudi pod povprečje držav GEM. Čeprav je raven zaznane inovativnosti med družinskimi podjetji v povprečju nižja po vsem svetu, so nekatere značilnosti obeh skupin podobne: zaznana inovativnost v obeh skupinah družinskih in nedružinskih podjetij je pozitivno povezana s stopnjo zaznane internacionalizacije in hkrati negativno z ravnijo BDP na prebivalca. 
Da se družinska in nedružinska podjetja razlikujejo v povprečni zaznani stopnji inovativnosti ali novosti svojih aktivnosti, je tudi posledica različnih značilnosti, ki jih lahko pripišemo posameznikom, ki so jedro družinskega podjetja in lahko vplivajo na inovativnost gospodarske dejavnosti, ki jo družinsko podjetje ponuja trgu. Kot vemo, je inovativnost tesno povezana z večjo stopnjo tveganja, družinska podjetja pa so manj nagnjena k tveganju kot nedružinska. Predhodne raziskave tudi kažejo, da se družinska in nedružinska podjetja razlikujejo tudi po socialnem kapitalu, še zlasti po mrežah in vezeh, ki so v družinskih podjetjih v večji meri zasebne narave. Ta dejstva potem prispevajo k povprečno manjši inovativnosti družinskih podjetij v primerjavi z nedružinskimi. Vpliv na inovativnost ima tudi podjetniški ekosistem in kakovost njegovega delovanja.

\section{Kakovost podjetniškega ekosistema}

Poslovno okolje podjetja ima na nastajajoča, nova in ustaljena podjetja močan vpliv. Pomemben del tega okolja je podjetniški ekosisem, ki ga tvorijo številni deležniki, ki vplivajo na podjetniško aktivnost. V raziskavi GEM kakovost podjetniškega ekosistema izražamo s pomočjo ocenjevanja okvirnih pogojev za podjetništvo, kjer z anketiranjem večjega števila skrbno izbranih izvedencev (podjetniki, managerji in drugi posamezniki iz gospodarstva, politike, državne uprave in akademske sfere, ki imajo izkušnje in znanje za delovanje na različnih področjih, povezanih s podjetništvom) pridobimo podrobnejši vpogled v ključne elemente podjetniškega konteksta. Področja tega konteksta zajemajo: podjetniške finance, vladne politike, vladne programe, izobraževanje za podjetništvo, prenos raziskav in razvoja, poslovno in strokovno infrastrukturo, dinamiko in odprtost notranjega trga, fizično infrastrukturo ter kulturne in družbene norme. Ta področja s pomočjo širokega nabora vprašanj izvedenci ocenijo na Likertovi lestvici od 0 (zelo nezadovoljivo) do 10 (zelo zadovoljivo).

Tako kot že vsa leta doslej ima med vsemi ocenjenimi podjetniškimi okviri v Sloveniji najvišjo oceno razpoložljiva fizična infrastruktura. Temu podjetniškemu pogoju sledijo dinamičnost notranjega trga ter kakovost poslovne in strokovne infrastrukture, ki jo potrebujejo nova in rastoča podjetja (lastninske pravice, poslovna infrastruktura, računovodske, pravne in druge storitve). V primerjavi z letom 2019 se je izboljšalo kar sedem okvirnih pogojev za podjetništvo, po oceni izvedencev najbolj, presenetljivo, kulturne in družbene norme, za katere so bile sicer vrsto let zabeležene zelo nizke povprečne ocene, izrazito pod povprečjem skupine evropskih držav, sodelujočih v raziskavi GEM. Temu sledi postopno izboljšanje izobraževanja za podjetništvo na vseh ravneh, kar nekoliko kaže tudi na razmeroma dobro obvladovanje izzivov večmesečnega zaprtja izobraževalnih ustanov v času pandemije. Pri vseh teh ocenah pa moramo ves čas upoštevati, da se je anketiranje zaključilo konec junija, ko posledice pandemije še niso bile izražene v polni meri.

V primerjavi z letom 2019 je največje poslabšanje zaznati pri vladnih programih za podjetništvo, kjer je povprečna ocena s 5,13 v letu 2019 padla na 4,47. Ta ocena je tudi najbolj pod povprečjem evropskih držav. Temu sledi kritična ocena vladne politike $\vee$ smislu regulative (davki in birokracija), pa tudi podpore. Pri teh okvirnih pogojih smo izraziteje tudi pod povprečjem ocen vseh sodelujočih držav GEM. Okvirni pogoji za podjetništvo, ki so v Sloveniji najslabše ocenjeni, so sicer še naprej enaki kot že nekaj let zapored; to so izobraževanje za podjetništvo na primarni in sekundarni ravni, vladne politike in nezadosten obseg, v katerem nacionalne raziskave in razvoj vodijo do novih poslovnih priložnosti in so na voljo MSP (obstoj in učinkovitost različnih mehanizmov za prenos raziskovalnih dosežkov in tehnologije z univerz in iz raziskovalnih centrov 
$\checkmark$ podjetniško prakso). Najniže v povprečju ostajajo ocenjeni izobraževanje in usposabljanje za podjetništvo na primarni in sekundarni ravni, vladne politike - tako v smislu regulative kot podpore ter prenos raziskav in razvoja.

Primerjava povprečnih ocen okvirnih pogojev za podjetništvo z evropskimi državami GEM in vsemi sodelujočimi državami kaže, da se Slovenija v letu 2020 nad povprečje Evrope uvršča pri štirih okvirnih pogojih, najizraziteje pri dinamičnosti notranjega trga in fizični infrastrukturi. Pri teh dveh okvirnih pogojih beležimo tudi višjo povprečno oceno, kot to velja za skupino vseh sodelujočih držav GEM. Čeprav so ocene profesionalne in strokovne infrastrukture v Sloveniji pozitivno rangirane, pa primerjava z Evropo pokaže, da so tudi na tem področju še možne izboljšave, enako velja za podjetniške finance. Spodbudno pa je, da smo se v letu 2020 glede na povprečne ocene izvedencev evropskemu povprečju približali oziroma ga celo presegli pri podjetniškem izobraževanju, pa tudi, kot smo že omenili, pri kulturnih in družbenih normah, kar so bili vrsto let okvirni pogoji za podjetništvo, pri katerih smo za Evropo zaostajali.

V letu 2020 so bili slovenski izvedenci ponovno najbolj kritični do hitrosti pridobivanja potrebnih dovoljenj in koncesij (povprečna ocena 2,88 na lestvici od 0 do 10). Najvišja povprečna ocena $v$ tem okviru je bila glede vladnih politik zabeležena za trditev, da je podpora za nova in rastoča podjetja velika prioriteta politike na državni ravni (povprečna ocena 4,49), v primerjavi z Evropo pa nas ta ocena kljub temu uvršča pod povprečje. Močno pod povprečjem evropskih držav smo tudi pri podpori za nova in rastoča podjetja na ravni občin in upravnih enot, temu sledi (ne)predvidljivost in (ne)konsistentnost davčne in druge vladne regulative za nova in rastoča podjetja. Najboljšo prakso pri spopadanju z birokracijo in regulativo po mnenju izvedencev med evropskimi državami predstavlja Nizozemska, ki je tudi sicer država s pogosto najvišjimi povprečnimi ocenami posameznih elementov v sklopu vladnih politik za podjetništvo.

S povprečno oceno 6,03 (na lestvici od 0 do 10) se izvedenci strinjajo, da v Sloveniji znanstveni parki in poslovni inkubatorji zagotavljajo učinkovito podporo za nova in rastoča podjetja, kar je višja ocena kot leto poprej, z njo pa se uvrščamo nad povprečje ocen izvedencev evropskih držav. Najvišje ocene so si v letu 2020 pri tej trditvi prislužile Nemčija, Nizozemska in Švica. Na ravni Evrope smo pri oceni uspešnosti vladnih programov, ki podpirajo nova in rastoča podjetja, najbolj pod povprečjem evropskih držav pa pri oceni števila vladnih programov za nova in rastoča podjetja. Najvišjo oceno med evropskimi državami glede primernega števila vladnih programov za nova in rastoča podjetja je sicer zabeležila Avstrija. Slovenski izvedenci med zaviralnimi dejavniki za podjetništvo v okviru vladnih programov najpogosteje izpostavljajo nekonsistentnost podpornih ukrepov, razpršenost sredstev po različnih deležnikih podpornega okolja, netransparentnost in neusklajenost med deležniki. Prepoznali pa so učinkovito podporno mrežo na regionalni in lokalni ravni (mreža Subjektov inovativnega okolja (SIO), SPOT točke, delovanje Obrtne in Gospodarske zbornice, regionalnih razvojnih agencij) ter bottom-up iniciativ, kot je Iniciativa Start:up Slovenija kot aktivna povezovalka in promotorka javnih in zasebnih deležnikov slovenskega startup ekosistema.

V raziskavi GEM ugotavljamo, da v Sloveniji raste delež ljudi, ki menijo, da je podjetništvo dobra izbira kariere, da se v vrh evropskih držav uvrščamo po deležu ljudi, ki menijo, da so uspešni podjetniki v slovenski družbi spoštovani in da je v medijih pogosto mogoče zaslediti primere dobre podjetniške prakse. Kljub temu pa so slovenski izvedenci kulturne in družbene norme vsa leta ocenjevali zelo kritično. V letu 2020 je mogoče zaznati pozitiven premik skupne ocene tega okvirnega pogoja. Kulturne in družbene norme so se v pandemiji covida-19 vendarle izkazale za bolj naklonjene podjetništvu kot leto poprej, je pa na tem področju zagotovo še veliko izzivov in zaviralnih dejavnikov. Slovenski izvedenci jih vidijo v še vedno prepogostem slabšalnem odnosu 
do poslovnega uspeha, $v$ enačenju podjetniške aktivnosti z akumuliranjem dobička in $v$ tem, da ljudje ne zaznavajo vloge podjetnikov pri zagotavljanju novih delovnih mest in prispevku $k$ razvoju ožje in širše skupnosti. Prav tako se tudi preveč stigmatizirajo podjetniki in podjetnice, ki so doživeli poslovne neuspehe. Po mnenju izvedencev je torej še vedno premalo ozaveščanja o pomenu podjetništva, sprejemanja drugačnosti in uspeha, kakor tudi razumevanja, da je podjetništvo tvegana dejavnost in da zato ne more uspeti prav vsak podjetniški poskus.

Od leta 2018v sklopu raziskave GEM pripravljamo tudi indeks NECI (ang. national entrepreneurship context index), s katerim zbirno ocenimo podjetniški kontekst v posamezni državi. Na osnovi odgovorov vseh ekspertov iz vseh sodelujočih držav se z metodo glavnih komponent definira 12 uteženih konstruktov oziroma spremenljivk za 12 okvirjev. Enostavna aritmetična sredina tako dobljenih vrednosti novih spremenljivk za posamezno državo predstavlja vrednost NECI, kar omogoča smiselno rangiranje držav. Na lestvici NECI med 44 sodelujočimi državami prva tri mesta zasedajo Indonezija, Nizozemska in Tajvan. Slovenija si z oceno 4,6, kar je višja ocena kot leto poprej, deli 15. mesto skupaj s Kolumbijo in Latvijo. Slovenija je primerjalno z drugimi državami po vrednosti indeksa NECl tik pod evropskim in svetovnim povprečjem (povprečna vrednost NECI za Evropo je 4,7 in je enaka tudi za vse države, sodelujoče v raziskavi GEM). Nekoliko izraziteje pa zaostajamo, če se po vrednosti indeksa NECl primerjamo z visokodohodkovnimi gospodarstvi (povprečna ocena 4,9). Primerjava vrednosti NECI za leti 2019 in 2020 sicer kaže, da se okvirni pogoji za podjetništvo v večini držav niso bistveno spremenili, torej vpliv gospodarske krize zaradi pandemije še ni bil v celoti zajet. Kakšni bodo vplivi krize zaradi covida-19 na okvirne podjetniške pogoje, bo tako bolj jasno ob meritvah leta 2021. Kljub temu pa smo na temelju dveh sklopov vprašanj pridobili nekoliko vpogleda v dogajanje. Namen prvega sklopa je bil zajeti mnenje nacionalnih izvedencev o tem, kako se je podjetniški sektor odzval na zapiranje (tako imenovani lock-down) zaradi pandemije covida-19, namen drugega pa dobiti od njih mnenje o vladnih ukrepih za pomoč novim in rastočim podjetjem.

Skupna povprečna ocena okvira, ki se nanaša na odziv podjetniškega sektorja na pandemijo, na lestvici od 1 do 10 znaša 6,73, kar pomeni, da so se nova in rastoča podjetja v Sloveniji, po mnenju nacionalnih izvedencev, proaktivno odzvala na zaprtje zaradi pandemije covida-19 (sprejela so nove načine poslovanja, spodbujala delo od doma, prilagodila svoje izdelke in storitve, odkrila nove poslovne priložnosti ipd.). Ocena nas uvršča v zgornjo polovico lestvice vseh sodelujočih držav GEM in nad povprečje Evrope, kjer ocena znaša 6,46. Kljub proaktivnemu odzivu podjetniškega sektorja pa so pri zgodnjih ukrepih vladnih politik za zajezitev posledic pandemije na področju gospodarstva zabeleženi slabši rezultati. Slovenski izvedenci so ta okvir ocenili s povprečno oceno 4,92, povprečje evropskih držav pa znaša 5,29. Večina izvedencev iz držav, sodelujočih v raziskavi GEM, ocenjuje zgodnji vladni odziv na pandemijo covida-19 kot nezadovoljiv ali nezadosten. $\vee$ svetovnem merilu so vladni ukrepi najviše ocenjeni $\vee$ Saudovi Arabiji, tesno pa ji sledijo Združeni arabski emirati in Nizozemska, ki je tudi sicer država, kjer podjetniška aktivnost tradicionalno uživa veliko podporo. Slovenski izvedenci so se najbolj strinjali, da je vlada med pandemijo covida-19 zaščitila delavce novih in rastočih podjetij in njihove stranke (povprečna ocena 5,94), vse preostale trditve so negativno rangirane, s povprečnimi ocenami nižjimi od 5. O vladnem odzivu na ekonomske posledice zaradi covida-19 smo povprašali tudi podjetnike, ki so na vprašalnik odgovarjali po tako imenovanem prvem valu, ki je obetalo izboljšanje epidemiološke situacije in so vladni ukrepi zaradi pandemije že prišli bolj do izraza. Več kot polovica ustaljenih podjetnikov (52,88 \%) meni, da se je slovenska vlada učinkovito odzvala na ekonomske posledice pandemije, kar je nekoliko nad evropskim povprečjem. 


\section{Uvodna predstavitev GEM}

\subsection{Kaj je Globalni podjetniški monitor (GEM)}

Podjetništvo je najmočnejše gonilo gospodarske rasti in razvoja in ima zelo velik vpliv na celoten družbeni razvoj. Je kompleksen sistem medsebojnih soodvisnosti gospodarskih, socialnih in kulturnih povezav. Tudi ni nacionalno samozadostno ali omejeno na posamezno državo. Zato ga je kot takšnega treba tudi raziskovati in spoznavati ter izluščiti tiste dejavnike, ki ga lahko zavirajo ali spodbujajo. Ker je podjetništvo mednarodno in globalno soodvisno, je pomembno, da ga raziskujemo in spoznavamo v sodelovanju in primerjanju z drugimi državami.

Prav to počne Globalni podjetniški monitor (GEM), ki imaza sebojzgodovino22-letnega raziskovanja podjetništva. Leta 1998 je bila pod vodstvom ameriškega Babson Collegea in London Business School ob sodelovanju desetih držav izvedena prva raziskava zgodnjega podjetništva. Slovenski raziskovalni tim z Inštituta za podjetništvo in management malih podjetij na Ekonomsko-poslovni fakulteti Univerze v Mariboru se je globalni raziskavi pridružil leta 2001 in naslednje leto smo v družbi 36 drugih držav izvedli prvo raziskavo. Od takrat sodelujemo v vseh letnih ciklih, tako da imamo za preteklih 19 let zanesljive podatke, s pomočjo katerih lahko pomembne elemente podjetništva v Sloveniji, še zlasti v njegovih začetnih fazah, primerjamo s podjetništvom v drugih državah, ki sodelujejo ali so sodelovale v GEM. Z raziskovanjem v družbi raziskovalcev GEM z vsega sveta dobivamo kompetentno informacijo, kam se $v$ globalnem merilu umešča podjetništvo $v$ Sloveniji.

Velika prednostGEM pred drugimipodjetniškimiraziskavamijenjegovaglobalnost, longitudinalnost in uporaba enotne metodologije, ki jo morajo sodelujoče države brezkompromisno uporabljati, saj lahko le na ta način zagotovimo, da so pridobljeni podatki zanesljivi in jih je potem možno tudi verodostojno uporabljati in tolmačiti. Tako lahko dobimo jasno sliko o stanju in razvoju podjetništva $\checkmark$ državi, oblikovalci podjetniške politike pa lahko bolje razumejo podjetniško problematiko in dobijo trdnejšo osnovo za pripravo in izbiro učinkovitih ukrepov in programov, ki podpirajo takšen tip podjetništva, ki lahko najbolje prispeva k družbenemu razvoju. To bo še posebej pomembno pri 
reševanju nekaterih velikih izzivov za družbo, kot so cilji trajnostnega razvoja Združenih narodov (SDG), ali pri iskanju rešitev in odpravljanju posledic, ki jih povzroča pandemija koronavirusa SARS-CoV-2. Pri odpravljanju negativnih vplivov pandemije na gospodarstvo bodo vlade številnih držav in druge zainteresirane strani vedno bolj potrebovale trdne, zanesljive in verodostojne podatke za sprejemanje ključnih odločitev, ki spodbujajo trajnostne oblike podjetništva in zdrave podjetniške ekosisteme po vsem svetu.

V 22 letih obstoja je Global Entrepreneurship Monitor (GEM) že večkrat prispeval k takim prizadevanjem. Nazadnje s posebno publikacijo Diagnosing COVID-19 Impacts on Entrepreneurship: Exploring policy remedies for recovery (ur. Aileen Ionescu-Somers in Anna Tarnawa, 2020), v kateri so med drugim navedeni tudi konkretni primeri, kako so se posamezne države v letu 2020 odzvale na trenutno pandemijo. To ni edina posebna publikacija, ki podrobneje proučuje katero izmed posebej perečih področij. Doslej je bilo dodatno proučeno žensko podjetništvo, podjetniško izobraževanje, v razvoj usmerjeno podjetništvo, podjetništvo v organizacijah, podjetništvo mladih in starejših, pregled podjetniških politik in primeri dobrih praks te politike.

Organizacijsko gledano, je GEM mrežni konzorcij nacionalnih timov z akademskih institucij ali posameznih uglednih inštitutov. Je edini globalni raziskovalni vir, ki podatke o podjetništvu zbira neposredno od potencialnih in obstoječih podjetnikov. Oblikovalci politiklahkozato sprejemajo bolj utemeljene odločitve, ki lahko bolje koristijo podjetnikom in ključnim deležnikom podjetniškega ekosistema. Gledano skozi številke, predstavlja GEM 22-letno serijo podatkov, ki omogočajo longitudinalno analizo držav ali skupine držav na različnih ravneh. GEM vsakoletno opravi od 160 do 200 tisoč anket in intervjujev s strokovnjaki in odraslo populacijo, vključno s podjetniki vseh starosti, in razpolaga s podatki iz 115 gospodarstev na vseh celinah sveta. Z analizami na temelju podatkov GEM je angažiranih okrog 500 strokovnjakov za raziskovanje podjetništva s približno 300 akademskih in raziskovalnih ustanov. Tolikšen raziskovalni potencial je poleg poglobljenih letnih raziskav ustvaril tudi skoraj 1000 znanstvenih člankov ali poglavij v monografijah, v katerih so uporabljeni podatki, zbrani v okviru globalnega raziskovalnega programa GEM.

V raziskovalnem ciklusu 2020 je bilo v raziskavo odrasle populacije vključenih 43 držav. Nekoliko manjše število držav kot pretekla leta je predvsem posledica pandemije, ki je v kar nekaj državah preprečila zanesljivo in kakovostno anketiranje in zbiranje podatkov, s tem pa seveda onemogočila sodelovanje v raziskavi. Sodelujoče države so prikazane v tabeli 1.1.

Tabela 1.1: Države GEM glede na regijo in stopnjo razvitosti, GEM 2020, APS

\begin{tabular}{|c|c|c|c|}
\hline & $\begin{array}{l}\text { Nizkodohodkovna } \\
\text { gospodarstva }\end{array}$ & $\begin{array}{l}\text { Srednjedohodkovna } \\
\text { gospodarstva }\end{array}$ & $\begin{array}{l}\text { Visokodohodkovna } \\
\text { gospodarstva }\end{array}$ \\
\hline $\begin{array}{l}\text { Vzhodna Azija in } \\
\text { Pacifik }\end{array}$ & & $\begin{array}{l}\text { Indija, Indonezija, } \\
\text { Kazahstan }\end{array}$ & Južna Koreja, Tajvan \\
\hline $\begin{array}{l}\text { Evropa in } \\
\text { Severna Amerika }\end{array}$ & & Rusija & $\begin{array}{l}\text { Avstrija, Ciper, Grčija, Hrvaška, Italija, } \\
\text { Kanada, Latvija, Luksemburg, Nemčija, } \\
\text { Nizozemska, Norveška, Poljska, Slovaška, } \\
\text { Slovenija, Španija, Švedska, Švica, Velika } \\
\text { Britanija, Združene države Amerike }\end{array}$ \\
\hline $\begin{array}{l}\text { Latinska Amerika } \\
\text { in Karibi }\end{array}$ & & Brazilija, Gvatemala & Čile, Kolumbija, Panama, Urugvaj \\
\hline $\begin{array}{l}\text { Bližnji vzhod in } \\
\text { Afrika }\end{array}$ & Burkina Faso & $\begin{array}{l}\text { Angola, Egipt, } \\
\text { Maroko, Togo, Iran }\end{array}$ & $\begin{array}{l}\text { Izrael, Katar, Kuvajt, Oman, Saudova } \\
\text { Arabija, Združeni arabski emirati }\end{array}$ \\
\hline
\end{tabular}


Delitev držav v tri dohodkovne skupine, ki je narejena po klasifikaciji Svetovnega gospodarskega foruma, je potrebna zato, ker je sicer nemogoče narediti smiselne primerjave med državami. $\checkmark$ našem primeru je delitev držav v skupine narejena po njihovi stopnji razvitosti. Ta namreč v veliki meri vpliva na razvitost podjetniškega okolja, v katerem poteka podjetniški proces. V 8. poglavju podrobneje govorimo o podjetniškem ekosistemu. Pojasnjene so njegove posamezne komponente, ki vplivajo tako na odnos do podjetništva kot na dostopnost kapitala, ustreznost poslovne infrastrukture ali vodenje podjetniške politike.

Države se tudi sicer močno razlikujejo kulturno, politično, demografsko itd., zato morajo biti ukrepi za spodbujanje podjetništva prilagojeni razvojni stopnji posamezne države. Pri nizkodohodkovnih državah gre predvsem za čim boljšo izkoriščenost osnovnih proizvodnih dejavnikov, kot so zemlja in primarne dobrine, in vzpostavitev ustrezne izobraževalne infrastrukture, saj je v teh državah delovna sila še v sorazmerno velikem deležu nekvalificirana, kar omejuje nastajanje prodornih podjetij in njihovo rast. Pogosto pa manjkajo tudi siceršnja infrastruktura (transportne povezave, elektrika, internet, pitna voda) in učinkoviti zdravstveni in šolski sistemi. V manj razvitih državah je tudi narava podjetniških priložnosti nekoliko drugačna in večinoma enostavnejša. To pa ne pomeni, da je enostavnejši tudi podjetniški proces, saj se podjetniki pri zasnovi in uresničevanju podjetniške priložnosti pogosto srečujejo s številnimi težavami.

Ker so v manj razvitih državah zaradi manjše prisotnosti večjih podjetij manjše možnosti za zaposlitev, so podjetni posamezniki prisiljeni v tako imenovano samozaposlitveno preživetveno podjetništvo, ki je ob odsotnosti delovnih mest pogosto edina možnost za dostojno preživetje. Takšno podjetništvo pa je manj prodorno, saj večina podjetniških priložnosti, ki jih ta tip podjetništva izkorišča, nima tolikšnega prihodkovnega potenciala, da bi omogočal večje zaposlovanje in rast. Z rastjo družbenega proizvoda se postopoma spreminjajo tudi relevantni dejavniki, ki omogočajo podjetništvo in vplivajo nanj, obenem pa narašča tudi število podjetij, ki so sposobna zaposlovati.

Slovenija po svoji ekonomski moči spada v visokodohodkovna gospodarstva. Ima relativno visok bruto družbeni proizvod na prebivalca, dobro razvito infrastrukturo, relativno urejeno poslovno okolje in dovoljstabilen gospodarski sistem. Čehočemo izboljšati podjetniški sistem in pospeševati kakovostno, v razvoj in rast usmerjeno podjetništvo, se moramo primerjati s podobnimi državami, predvsem pa s tistimi, ki imajo posamezne segmente, ki vplivajo na podjetništvo, bolje urejene kot Slovenija. GEM pri tem zagotavlja zanesljivo podatkovno podlago za nekatere primerjave in razmisleke, potrebne pri snovanju primernega podjetniškega okolja in ustrezne podjetniške politike, ki podpira kakovostno podjetništvo. Zato ga tudi posamezne države obilno uporabljajo pri iskanju najboljših ukrepov, ki lahko odpravijo pomanjkljivosti v podjetniškem okolju.

\subsection{Konceptualni okvir GEM in spremljanje podjetniškega ekosistema in procesa}

Osrednji nosilec podjetniške pobude je posameznik, ki sam ali v sodelovanju z drugimi podjetnimi posamezniki najde ali ustvari podjetniško priložnost, ta pa omogoča proizvode ali storitve, ki zadovoljujejo eno ali več potreb kupcev. Čeprav je podjetnost sicer splošna človeška lastnost, ki je pri posameznikih različno močno izražena, pa niso vsi ljudje pripravljeni stopiti na podjetniško pot. Vozadju konceptualnega okvira GEM je prav premisa, da je podjetni posameznikjedro podjetniškega procesa, njegovi motivi, nagnjenja in dejanja pa so vselej v tesni interakciji z njegovim kulturnim, družbenim in gospodarskim okoljem. Zato GEM pri svojem raziskovanju tudi upošteva, da sta 
nacionalna gospodarska rast in razvoj posledica osebnih sposobnosti posameznikov za odkrivanje in izkoriščanje priložnosti, bodisi samostojno ali v okviru podjetja, kakor tudi, da je ta proces pomembno odvisen od gospodarskega in družbenega okolja, ki vpliva na posameznikov odnos do razpoznavanja in njegove zmožnosti za uspešno izkoriščanje podjetniških priložnosti. Zato v raziskovanju ni mogoče zaobiti podjetniških ambicij, inovativnosti in podjetnosti, pa tudi ne strahov, razlogov in omejitev, ki usposobljenim posameznikom preprečujejo, da bi se usmerili v podjetništvo.

Velik vpliv na vključevanje posameznikov $v$ podjetniške aktivnosti ima njihovo neposredno življenjsko okolje, predvsem prevladujoče kulturne vrednote, nagnjenost družbe k podjetništvu in urejenost poslovnega okolja. Temu ustrezno je zastavljen konceptualni okvir GEM, ki omogoča obravnavanje posameznikov in njihovega odnosa do podjetništva, dojemanja podjetništva ter vključenosti v ustanavljanje in/ali lastništvo in vodenje podjetja. Z njegovo pomočjo lahko zato dobimo bolj poglobljen vpogled $v$ nacionalno podjetništvo in njegove značilnosti in bolj popolno sliko, kot jo lahko zagotovijo različni statistični viri, ki temeljijo zgolj na podatkih, pridobljenih od obstoječih podjetij. GEM namreč zajame tudi odnos posameznika in družbe do podjetništva, njegove ambicije in usposobljenost za podjetništvo, pa tudi posameznike $v$ vseh fazah podjetniškega procesa, od začetnih razmislekov, da bi se podali na podjetniško pot, do ustanovitve podjetja, poslovanja, rasti in prenehanja poslovanja. Zajame pa tudi notranje podjetništvo in posamezne bolj poglobljene teme, kot je recimo gig ekonomija (GEM 2019), vpliv pandemije covida-19 (GEM 2020) ali sledenje ciljem trajnostnega razvoja (GEM 2021).

Raziskovanje posameznikov je pomembno, ker lahko s tem zajamemo tudi informacije o »neformalnem« gospodarstvu ali o raznovrstnem naboru gospodarskih dejavnosti, podjetij in delovnih mest, ki jih država ne ureja in ne ščiti, še zlasti v tistih državah, kjer uradni viri ta področja slabo zajemajo ali so njihove informacije manj zanesljive. V teh državah, zlasti manj razvitih, posamezniki morda ne registrirajo podjetja, ampak preprosto izkoristijo priložnosti za posel takrat, ko se pojavijo. Taka neuradna dejavnost očitno ni zajeta v uradnih statistikah, vendar je lahko pomemben del nacionalnega gospodarstva (Bosma et al., 2020). Da bi lahko vse te dejavnike ustrezno opazovali, so bile razvite mere, ki omogočajo usklajeno pridobivanje podatkov ter harmonizacijo podatkov in dobljenih rezultatov, da se lahko države primerjajo med seboj. Te mere izhajajo iz konceptualnega okvira GEM (slika 1.1), ki zajema več skupin ključnih dejavnikov podjetniškega procesa: stanje $v$ podjetniškem ekosistemu, družbene vrednote in dojemanje podjetništva, individualne značilnosti potencialnega podjetnika, posamezne faze podjetniške aktivnosti ter podjetniške aspiracije.

Družbeni, kulturni, politični in ekonomski kontekst se nanaša na stopnjo splošne razvitosti posameznega nacionalnega gospodarstva in še posebej na razvitost ključnih podjetniških pogojev. Okvir nacionalnih pogojev kaže razvitost inštitucij, infrastrukturo, makroekonomsko stabilnost, zdravstveno in primarno izobraževanje, visoko izobraževanje in usposabljanje, učinkovitost trga dobrin, učinkovitost trga delovne sile, izpopolnjenost finančnega trga, tehnološko usposobljenost, velikost trga, poslovno urejenost in inovacije. Vse to je potrebno za normalno dolgoročno delovanje podjetij in se seveda med posameznimi državami razlikuje. Pri tem igra veliko vlogo gospodarska razvitost države, vendar to ne pomeni, da imajo bolje razvite države že tudi avtomatsko bolje urejeno to področje, vsaj ne vseh njegovih sestavin, in obratno, da imajo manj razvite države slabo razvite tudi vse navedene dejavnike. Okvir podjetniških pogojev zajema dejavnike, ki še posebej vplivajo na začetek in potek podjetniškega procesa v določeni državi. Podrobneje je to prikazano v 8. poglavju o podjetniškem ekosistemu. Ta se ocenjuje s pomočjo strokovnih mnenj skrbno izbranih izvedencev, ki imajo dober vpogled v različne segmente podjetniškega procesa. Pri ocenjevanju tega podjetniškega okvira se uporablja tudi sestavljeni indeks NECI (ang. national entrepreneurship context index), ki podaja oceno okolja za podjetništvo v nacionalnem gospodarstvu. 
Slika 1.1: Konceptualni okvir GEM

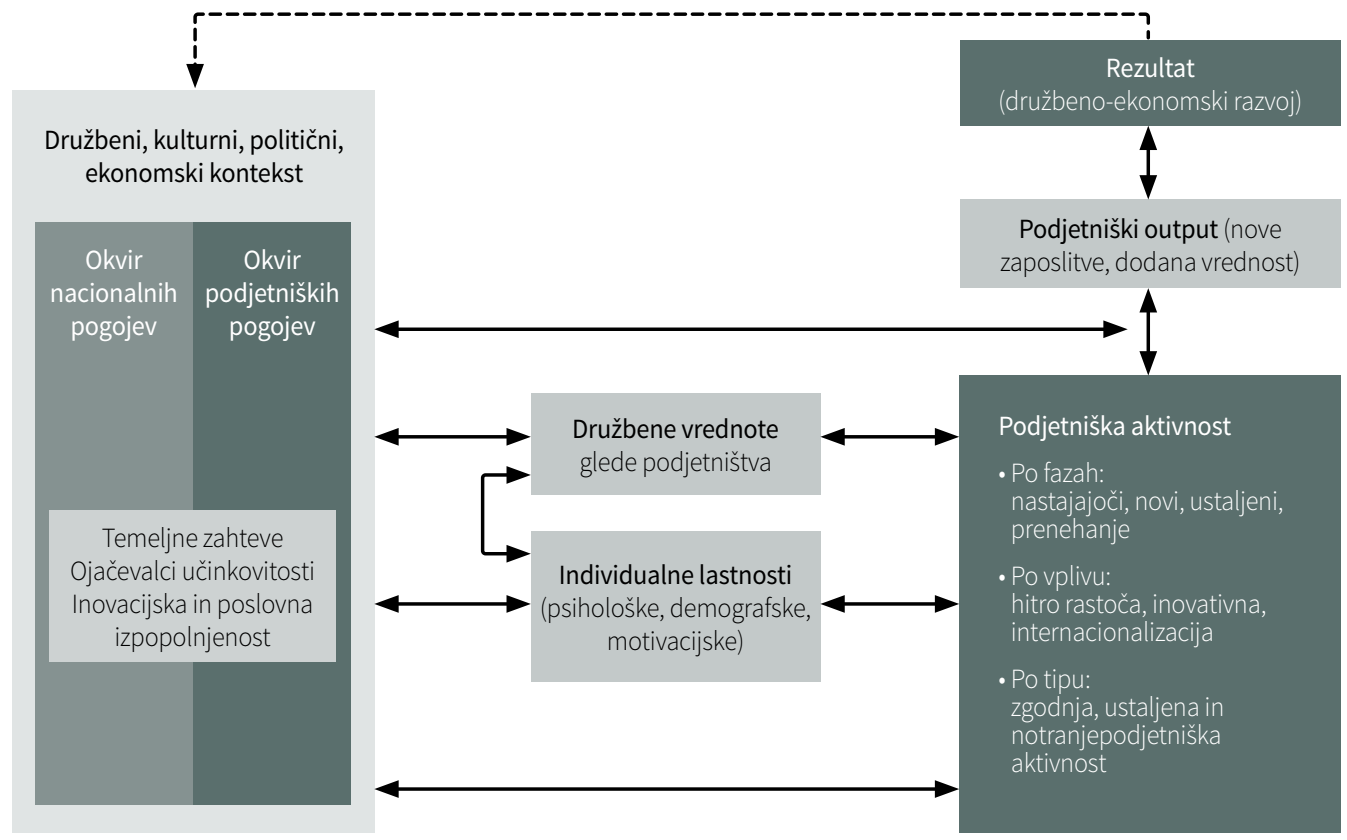

GEM 2020

Družbene vrednote in dojemanje podjetništva spoznavamo s pomočjo anketiranja odrasle populacije in njenih odgovorov na vprašanja, kot so: ali družba sprejema podjetništvo kot dobro karierno izbiro, ali imajo podjetniki visok družbeni status ter kolikšno pozornost posvečajo podjetništvu mediji in s tem prispevajo k razvoju podjetniške kulture. S pomočjo odgovorov na ta vprašanja lahko bolje razumemo pomen različnih dejavnikov, ki lahko vplivajo na to, ali se bo posameznik odločil za podjetniško pot ali ne, in k temu prispevajo. To tudi omogoča razmislek o možnostih, da bi posamezniki dejansko realizirali svoje podjetniške namere.

Ker je v jedru podjetniškega procesa vselej posameznik, imajo njegove individualne značilnosti še posebej pomemben vpliv na podjetniški proces, ki ga prikazujemo na sliki 1.2. Še zlasti so te značilnosti pomembne v najzgodnejših fazah podjetniškega procesa. Spoznavamo jih s pomočjo psiholoških dejavnikov (samozaznavanje osebnih zmogljivosti za podjetništvo, zaznavanje poslovnih priložnosti, strah pred neuspehom) ter motivacijskih vidikov (prispevek kspremembam v svetu, doseganje večjega premoženja, nadaljevanje družinskega podjetja, preživetje). Vključujemo tudi nekatere demografske dejavnike, kot so starost, spol, geografska lokacija, dohodkovno stanje družine. Zanima nas podjetniški potencial, da bi ocenili delež potencialnih podjetnikov, to je tistih, ki menijo, da imajo dovolj znanja in podjetniških sposobnosti, da bi lahko začeli s podjetništvom, ki prepoznavajo poslovne priložnosti v svojem okolju in jih strah pred potencialnim neuspehom njihovega podjema ne bi odvrnil od ustanovitve podjetja. 


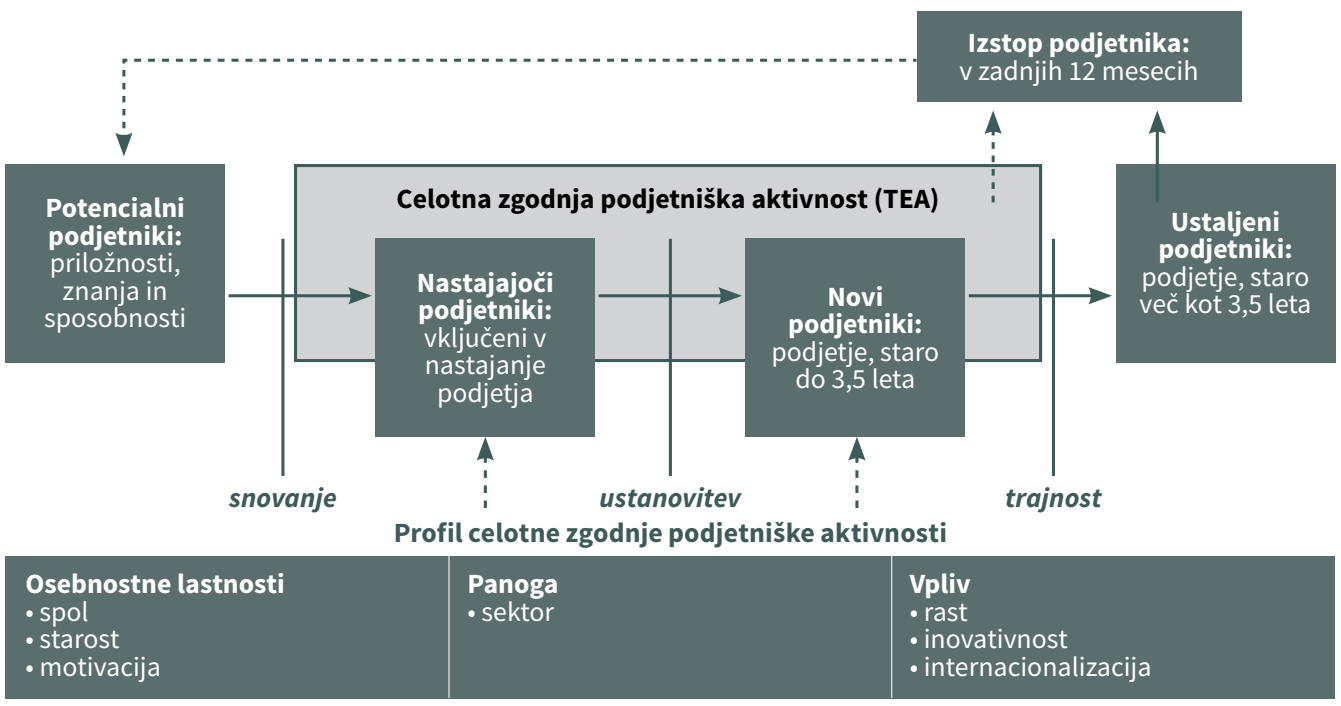

GEM 2020

Podjetniško aktivnost proučuje GEM glede na fazo življenjskega cikla podjema, ki teče od temeljne poslovne ideje in razmisleka ter aktivnosti posameznikov, da bi se lotili podjetništva, do opustitve poslovanja in morebitne zasnove novega podjetja. Posamezniki, ki jih proučujemo, se tako nahajajo na različnih stopnjah razvoja svojega podjetja. Nastajajoči podjetniki so tisti, ki so zato, da bi se začeli ukvarjati s podjetništvom, že vložili svoj čas in morebiti tudi denarna sredstva, z omejitvijo, da plač še ne izplačujejo dlje kot tri mesece. Novi podjetniki so posamezniki, ki so lastniki podjetja in ga tudi vodijo, to podjetje pa plač ne izplačuje dlje kot tri leta in pol. Ustaljeni podjetniki so tisti, ki imajo podjetje, ki plače izplačuje že dlje kot tri leta in pol. Določen delež podjetnikov poslovanje tudi opusti, kar je prav tako evidentirano. Zbir nastajajočih in novih podjetnikov predstavlja celotno zgodnjo podjetniško aktivnost, ki jo izražamo z indeksom TEA. V okviru kazalnika TEA se analizira tako imenovani profil zgodnje podjetniške aktivnosti, v okviru katerega proučujemo izbrane značilnosti teh podjetnikov, med katerimi so osebnostne lastnosti (spol, starost in motivacija), panoge in aspiracije podjetnikov po rasti, inovativnosti in internacionalizaciji podjetja. Dodatno kreiramo še indeks EBO, ki prikazuje delež ustaljenih podjetnikov, in indeks EEA, ki prikazuje delež notranjih podjetnikov.

Podrobna razlaga ključnih mer, s katerimi proučujemo dejavnike na navedenih treh področjih, je dodana na koncu te monografije kot priloga 2.

Na temelju tako zasnovanega koncepta lahko GEM uresničuje svoje poslanstvo, ki ga izvaja tako, da:

- meri razlike $v$ odnosu do podjetništva, aktivnosti in $v$ aspiracijah posameznikov $v$ čim večjem številu držav,

- odkriva dejavnike, ki spodbujajo ali ovirajo podjetniško aktivnost, še zlasti v odnosu do družbenih vrednot, osebnih značilnosti in podjetniškega ekosistema,

- zagotavlja platformo za ocenjevanje vpliva podjetniške aktivnosti na ekonomsko rast v določenem gospodarstvu ter

- odkriva potrebne politične ukrepe za krepitev podjetništva. 
Zaradi raznolikosti številnih držav, ki sodelujejo v raziskavi, in značilnosti njihovega poslovnega okolja ima raziskovanje na globalni ravni številne omejitve, ki jih je bilo treba upoštevati pri konceptualizaciji raziskovanja tako pri metodologiji kot pri zasnovi vprašalnikov in načinov pridobivanja podatkov, pa tudi pri njihovi harmonizaciji. Gre za precejšen izziv, saj zaradi razlik med državami večinoma ni mogoče uporabljati nacionalnih statističnih virov in registracijskih podatkov o podjetjih tako, kot jih uporabijo pri številnih drugih podjetniških raziskavah. Velika neusklajenost in raznolikost teh virov med državami, pogosto pa tudi neprimerljivost posameznih podatkovnih baz zahtevajo drugačen pristop. Ne nazadnje tudi zato, ker za številne značilnosti, ki jih ugotavlja GEM, takšnih baz sploh ni, saj se GEM osredotoča na podjetnega posameznika, ki se odloči za podjetniško kariero in ustanovi podjetje. Razlika med podatki, ki jih pridobimo v GEM, in podatki, ki jih zagotavljajo različni statistični viri, je strnjeno predstavljena v prilogi 2.

GEM se tudi sicer razlikuje od številnih drugih raziskav podjetništva, in to ne samo v tem, da gre za longitudinalno in globalno raziskavo. Medtem ko večina razpoložljivih podatkov o podjetništvu prikazuje število in velikost podjetij z uporabo objavljenih virov, kot so registracije podjetij ali napovedi o davku na dodano vrednost, se GEM osredotoča na posameznike in njihove podjetniške značilnosti, ambicije, strahove in aktivnosti.

\subsection{Podatkovne podlage za GEM}

Raziskava GEM vsako leto temelji na zanesljivih primarnih podatkih, ki jih predstavljajo slučajni vzorci odrasle populacije $v$ sodelujočih državah (ang. adult population survey - APS) ter vzorci nacionalnih izvedencev (ang. national expert survey - NES). Poleg tega primarne podatke $v$ raziskavi GEM povezujemo z zanesljivimi sekundarnimi podatki inštitucij, kot so Evropska komisija, Svetovna banka in druge.

APS v vsaki sodelujoči državi vključuje reprezentativen vzorec najmanj 2000 odraslih oseb, ki daje informacije o njihovih podjetniških dejavnostih, stališčih, motivacijah in ambicijah, pokriva pa tudi zelo raznolike značilnosti nepodjetnikov, vselej z uporabo istega standardiziranega vprašalnika GEM, ki jev vseh sodelujočih državah enak in preveden v nacionalne jezike. Načini izvedbe anketne raziskave so primerni razmeram v posameznih gospodarstvih in obsegajo telefonsko anketiranje (fiksni in/ali mobilni telefoni), načine preko internetnih panelov, v nekaterih državah pa tudi (delno ali v celoti) z osebnim anketiranjem. To zagotavlja reprezentativnost vzorca odrasle populacije v vseh sodelujočih državah. Zbrane podatke nato tehnično-metodološka skupina GEM preveri na osnovi razvitega sistema kazalnikov kakovosti podatkov. Strog metodološki pristop GEM rezultate ankete tako preoblikuje $v$ natančne mere podjetniške dejavnosti. Vsak nacionalni tim tako preoblikovane baze podatkov analizira, podatke pa spremeni v koristne informacije za oblikovalce ekonomske politike in informacije za spremljanje in oceno učinkov ukrepov ekonomske politike in pobud. Metodologija raziskave in proces harmoniziranja podatkov ter testiranje modela GEM so opisani v znanstveni literaturi (Reynolds et al., 2005; Levie in Autio, 2008).

Z anketiranjem odraslega prebivalstva pridobimo vpogled $v$ značilnosti podjetniških dejavnosti $\checkmark$ določenem gospodarstvu. Vendar pa se gospodarstva in socialni sistemi razlikujejo po gospodarskem, družbenem in političnem kontekstu, ki lahko na eni strani spodbuja in podpira podjetniško dejavnost, lahko pa ljudi omejuje ali celo odvrača od te dejavnosti. Da bi razumeli posamezne okvirne pogoje za podjetništvo v nacionalnem gospodarstvu, bazo podatkov APS $\checkmark$ posamezni sodelujoči državi dopolnjuje NES, ki zbira ocene skrbno izbranih posameznikov o različnih vidikih podjetniškega ekosistema; za te posameznike velja, da imajo zelo dobro strokovno znanje in zelo dobro poznajo nacionalno poslovno okolje. Vsak identificiran nacionalni 
strokovnjak izpolni vprašalnik NES o več različnih vidikih podjetniškega ekosistema, ki segajo od razpoložljivosti podjetniškega financiranja do državnih programov za podporo podjetništvu, od kakovosti podjetniškega izobraževanja na različnih ravneh do razpoložljivosti in stroškov fizične infrastrukture itd. Podobno kot APS je podroben vprašalnik, ki ga izpolnijo nacionalni strokovnjaki, v vseh sodelujočih državah enak in tematsko usklajen z vprašalnikom APS. Poleg tega strokovnjaki predstavijo svoje poglede na tri temeljne slabosti, ki podjetniško dejavnost v državi ovirajo, tri temeljne prednosti, ki podjetniško dejavnost pospešujejo, in tri priporočila za izboljšanje podjetniškega okolja.

Anketiranje odraslega prebivalstva je osrednji vir primarnih podatkov; anketiranje v vsaki od sodelujočih držav izvede usposobljena agencija. VSloveniji je anketiranje izvedlo podjetje Mediana $\checkmark$ času od maja do julija 2020. Zaradi pandemije covida-19 se je v nekaterih sodelujočih državah zbiranje podatkov izvedlo v daljšem času, najkasneje pa do oktobra 2020. Ker je v tem času pandemija prešla iz prvega vala v drugega, je treba pri primerjavah med državami upoštevati, da to dejstvo v določenih segmentih morda spreminja zaznave ljudi - nepodjetnikov in podjetnikov (spomladi ali jeseni 2020). Značilnosti vzorca v Sloveniji so prikazane v tabeli 1.2. Struktura vzorca je usklajena s strukturo statistične množice glede na statistične regije v Sloveniji (12 regij), glede na spol in starost ljudi ter glede na značilnost območja (urbano ali ruralno okolje). Vzorci vseh držav so uteženi na osnovi standardizirane ocene strukture prebivalstva po starosti in spolu; to vsako leto za vse države zagotavlja US Census International Population Data Base.

Tabela 1.2: Značilnosti uteženega in neuteženega vzorca, GEM Slovenija 2020, APS

\begin{tabular}{|l|r|r|r|}
\hline & Neuteženi vzorec (18 do 88 let) & Uteženi vzorec (18 do 64 let) \\
\hline Skupaj & 2000 & 1566 \\
\hline Moški & 989 & 812 \\
\hline Ženske & 1011 & 754 \\
\hline Število nastajajočih podjemov & 47 & 48 \\
\hline Število novih podjemov & 44 & 46 \\
\hline Število ustaljenih podjetij & 113 & 109 \\
\hline Neformalni investitorji & 79 & 66 \\
\hline
\end{tabular}

Leta 2020 je v raziskavi GEM sodelovalo 43 držav, ki jih v raziskavi GEM v skladu z letno klasifikacijo Svetovnega gospodarskega foruma (Schwab in Zahidi, 2020; Reberniketal., 2019; Bosma etal.,2020) grupiramo v skupine glede na dohodek na nizkodohodkovna gospodarstva, srednjedohodkovna gospodarstva, kjer ločimo spodnjo in zgornjo polovico držav, tervisokodohodkovna gospodarstva. Kot rečeno, je v ospredju metodološkega dela GEM anketiranje odraslega prebivalstva. V tabeli 1.3 prikazujemo skupno strukturo anketiranih oseb v okviru APS raziskave GEM 2020. 
Tabela 1.3: Število anketiranih oseb v vzorcih sodelujočih državah po tipih gospodarstva, GEM 2020, APS

\begin{tabular}{|c|c|c|c|c|}
\hline \multirow[b]{2}{*}{ Gospodarstva } & \multirow{2}{*}{$\begin{array}{r}\text { Število } \\
\text { držav }\end{array}$} & \multicolumn{2}{|c|}{$\begin{array}{r}\text { Število anketiranih oseb v starosti } \\
\text { od } 18 \text { do } 64 \text { let v vzorcu }\end{array}$} & \multirow{2}{*}{$\begin{array}{r}\text { Skupno število } \\
\text { anketiranih oseb }\end{array}$} \\
\hline & & $\min$. & maks. & \\
\hline Nizkodohodkovna & 1 & 2.325 & 2.325 & 2.325 \\
\hline Srednjedohodkovna (spodnja polovica) & 6 & 2.000 & 3.527 & 16.223 \\
\hline Srednjedohodkovna (zgornja polovica) & 5 & 2.000 & 3.144 & 12.149 \\
\hline Visokodohodkovna & 31 & 1.509 & 26.075 & 105.245 \\
\hline \multicolumn{4}{|l|}{ Skupno število anketiranih oseb } & 135.942 \\
\hline
\end{tabular}

Drugi primarni vir podatkov, ki ga uporablja GEM, je NES. Leta 2020 je bilo anketiranih 44 držav. V Sloveniji je anketiranje, tako kot v drugih državah GEM, potekalo od maja do junija 2020. Skupaj je bilo anketiranih 1.821 nacionalnih izvedencev, kar je po skupinah držav glede na tip gospodarstva prikazano v tabeli 1.4 .

Tabela 1.4: Število sodelujočih nacionalnih izvedencev v sodelujočih državah po tipih gospodarstva, GEM 2020, NES

\begin{tabular}{|l|r|r|r|r|} 
& & Število nacionalnih izvedencev & $\begin{array}{r}\text { Skupno število } \\
\text { nacionalnih } \\
\text { Tizvedencev }\end{array}$ \\
\cline { 3 - 5 } Tip gospodarstva & držav & min. & maks. & 70 \\
\hline Nizkodohodkovna & 2 & 31 & 39 & 251 \\
\hline Srednjedohodkovna (spodnja polovica) & 4 & 37 & 81 & 319 \\
\hline Srednjedohodkovna (zgornja polovica) & 8 & 14 & 72 & 1.181 \\
\hline Visokodohodkovna & 30 & 36 & 92 & $\mathbf{1 . 8 2 1}$ \\
\hline Skupno število nacionalnih izvedencev & & & & \\
\hline
\end{tabular}

\subsection{Dostopnost raziskav in podatkov GEM}

GEM je konzorcij nacionalnih timov, ki so povezani v krovno organizacijo Global Entrepreneurship Research Association (GERA), v okviru katere se izvaja projekt GEM. Konzorcij GEM je edinstvena mreža številnih podjetniških raziskovalcev, ki gradijo podatkovno bazo, da bi z njeno pomočjo pridobili trdnejša spoznanja o podjetniških pojavih. Na domači strani konzorcija GEM (www. gemconsortium.org) in tudi na slovenski strani (www.gemslovenia.org) lahko zainteresirani bralci najdejo številne informacije - od nacionalnih raziskav do podatkovnih baz in pregleda vse bogatejše zbirke znanstvenih člankov, ki nastajajo z uporabo podatkov, pridobljenih v raziskavah GEM. Od leta 2012 so podatkovne baze za pretekla leta urejene tako, da ponujajo možnosti primerjav posameznih indikatorjev med državami (glej https://www.gemconsortium.org/data), kar je še posebej priročno za nekatere hitre preglede stanja podjetništva v posameznih državah in medsebojne primerjave. 



\section{Nacionalni profil: Slovenija}
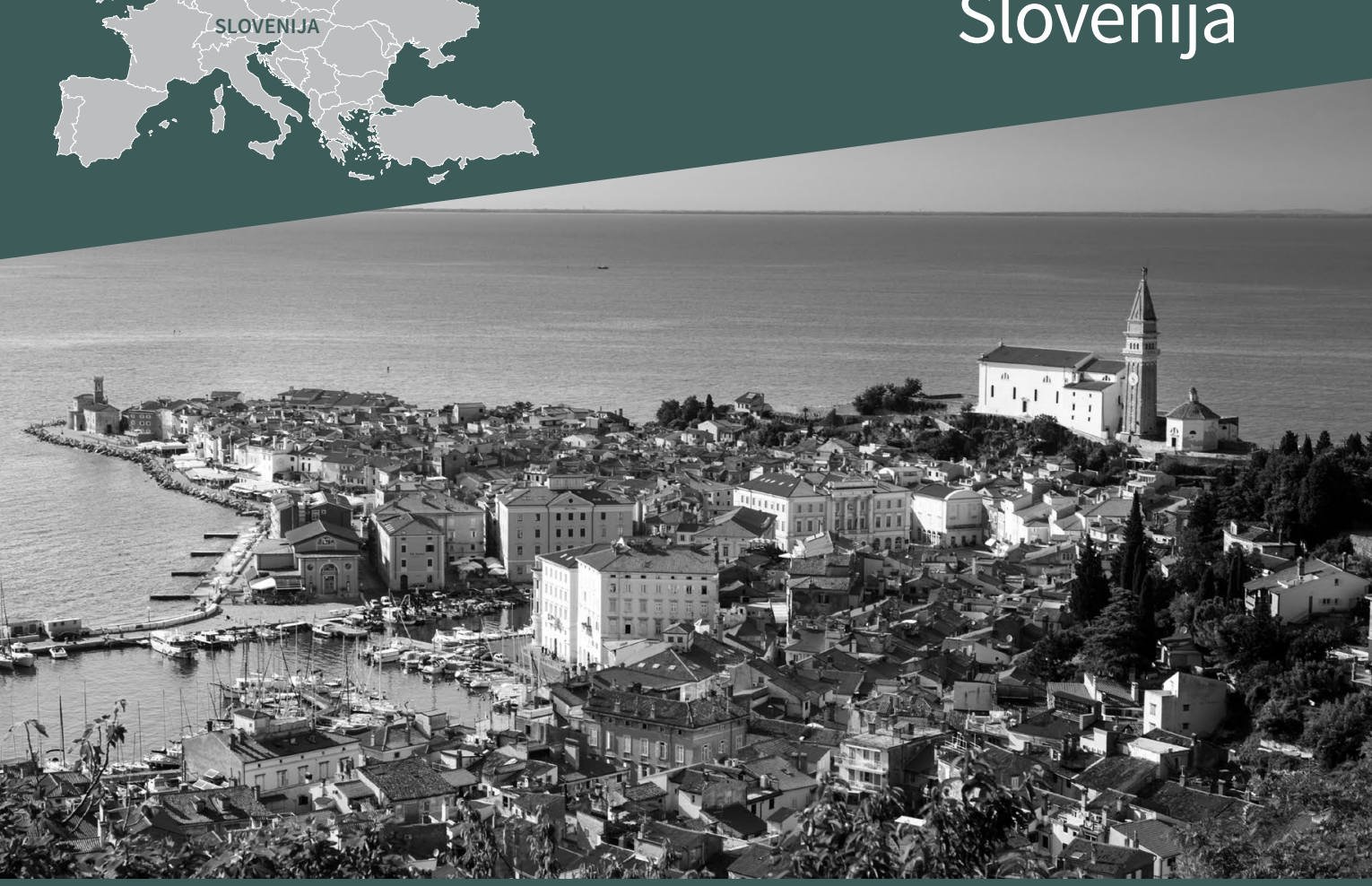

\section{Število prebivalcev: \\ 2,1 milijona (2020)}

Rast BDP:

$-5,5 \%(2020)$

BDP na prebivalca:

$40.846 €(2020)$

\begin{tabular}{lrr} 
Odnos do podjetništva & $\begin{array}{r}\text { \% odraslega } \\
\text { prebivalstva }\end{array}$ & Rang / 43 \\
\hline Poznavanje podjetnika & 57,9 & 22 \\
\hline Zaznavanje poslovnih priložnosti & 42,0 & 29 \\
\hline $\begin{array}{l}\text { Zaznana enostavnost ustanovitve } \\
\text { lastnega podjetja }\end{array}$ & 62,0 & 17 \\
\hline Znanje in veščine & 59,4 & 23 \\
\hline Strah pred neuspehom & 43,8 & 18 \\
\hline Podjetniške namere & 12,0 & 30 \\
\hline
\end{tabular}

\begin{tabular}{lrrrrr} 
Podjetniška aktivnost & $\begin{array}{r}\text { \% odraslega } \\
\text { prebivalstva }\end{array}$ & Rang / 43 & \% žensk & \% moških \\
\hline Celotna zgodnja podjetniška aktivnost (TEA) & 6,0 & 38 & 4,8 & 7,1 \\
\hline Stopnja ustaljenega podjetništva & 7,0 & 17 & 4,6 & 9,2 \\
\hline Podjetniška aktivnost zaposlenih & 5,2 & 12 & 3,2 & 7,0 \\
\hline
\end{tabular}




\begin{tabular}{lllll}
\hline Ustvariti spremembo v svetu & 44,6 & 19 & 43,6 & 45,2 \\
\hline Ustvariti premoženje oziroma večji dohodek & 39,7 & 38 & 52,5 & 31,6 \\
\hline Nadaljevati družinsko podjetje/tradicijo & 21,6 & 29 & 23,9 & 20,2 \\
\hline Preživeti, saj so službe redke & 72,2 & 20 & 77,9 & 68,7 \\
\hline
\end{tabular}

\begin{tabular}{lrr} 
Vpliv podjetništva & $\begin{array}{c}\text { \% odraslega } \\
\text { prebivalstva }\end{array}$ & Rang / 43 \\
\hline Pričakovana nova delovna mesta (+6 zaposlenih) & 1,5 & 27 \\
\hline Mednarodno poslovanje (+25\% prihodkov) & 1,2 & 16 \\
\hline Nacionalni obseg poslovanja (kupci in proizvodi/procesi) & 1,1 & 24 \\
\hline Globalni obseg poslovanja (kupci in proizvodi/procesi) & 0,5 & 15 \\
\hline Panoga (\% TEA v dejavnosti poslovnih storitev) & 22,7 & 19 \\
\hline
\end{tabular}

Ocena nacionalnih izvedencev o podjetniškem ekosistemu

(tehtano povprečje, 0 = zelo nezadovoljivo, 10 = zelo zadovoljivo) rang / 45 držav GEM

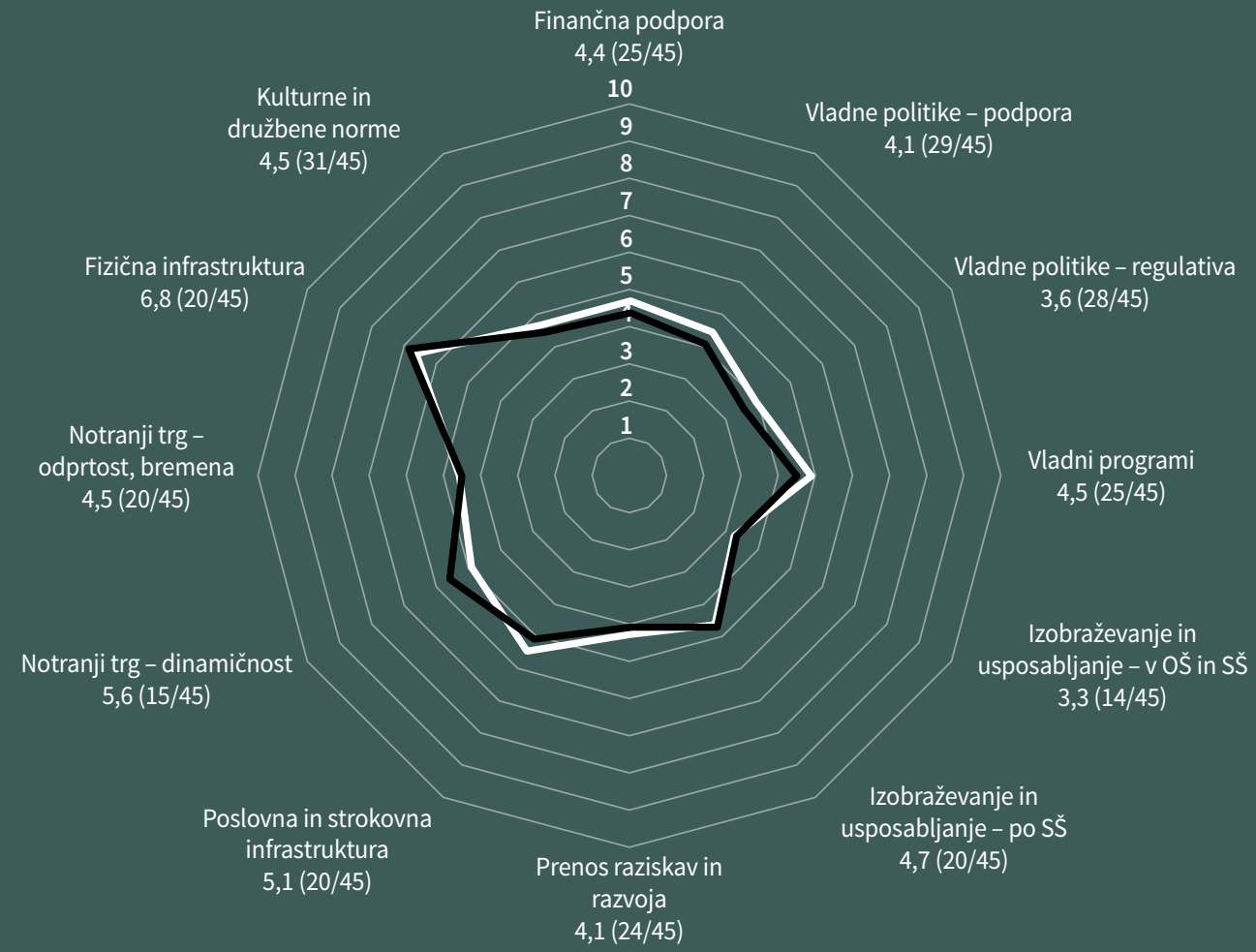




\section{GEM-ova preglednica značilnosti podjetništva v Sloveniji}

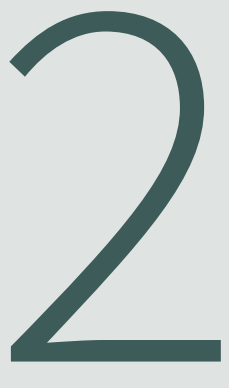

$\checkmark$ tabelaričnem prikazu $v$ tem poglavju podajamo posnetek stanja različnih vidikov podjetniške aktivnosti v Sloveniji v letu 2020 primerjalno z letom 2019. Kjer je mogoče, podajamo tudi mesto Slovenije med proučevanimi državami (rang), čeprav države, vključene v raziskavo GEM, niso v vseh letih iste. Podjetniško aktivnostv letu 2020 je zaznamovala pandemija covida-19. V času anketiranja odraslega prebivalstva v Sloveniji je država preživljala tako imenovani prvi val pred poletjem 2020, ko se je obetalo izboljšanje epidemiološke situacije. Veliko število držav, ki so sodelovale v raziskavi GEM, se je v procesu zbiranja podatkov soočilo z velikimi težavami pri izvedbi anketiranja in dostopnosti anketirancev, tako da so nekatere države zaključile z zbiranjem podatkovšele jeseni 2020, krepko v drugem valu epidemije. To pomeni, da lahko rezultati rangiranja držav po vrednostih posameznih kazalnikov odražajo tudi različno stanje podjetniškega ekosistema posamezne države glede na njeno epidemiološko stanje, to pa vpliva tako na poslovanje ustaljenih podjetij kot tudi na nastajanje novih podjetij ter na raven podjetniškega optimizma in s tem povezanih podjetniških namer.

Na sliki 2.1 prikazujemo podjetniške namere med odraslim prebivalstvom v Sloveniji v letu 2020, ki so se oblikovale v okolju, ki ga je pandemija močno zaznamovala. Več kot polovica prebivalcev je tako v povprečju menila, da ima pandemija vsaj majhen vpliv na podjetniške namere ljudi (51,40 \%), da je ta vpliv velik, pa je menila več kot petina anketiranih (20,59\%). Domnevamo lahko, da je to tudi eden izmed razlogov, zaradi katerih so se podjetniške namere ljudi v Sloveniji v povprečju zmanjšale. V letu 2020 jih je 13,27 \% menilo, da bodo v prihodnjih treh letih ustanovili svoje podjetje, v letu 2019 pa je bilo takih 16,59\%. Med tistimi odraslimi, ki še niso vključeni v nobeno obliko podjetniške aktivnosti, je tistih, ki nameravajo v prihodnjih treh letih ustanoviti svoje podjetje, še nekoliko manj, in sicer $11,95 \%$. V naslednjih poglavjih opisujemo vpliv pandemije covida-19 na podjetniško aktivnost v Sloveniji in v sodelujočih državah GEM še z različnih drugih vidikov. 
Slika 2.1: Podjetniške namere odraslega prebivalstva Slovenije ter zaznani vpliv pandemije covida-19 na podjetniške namere

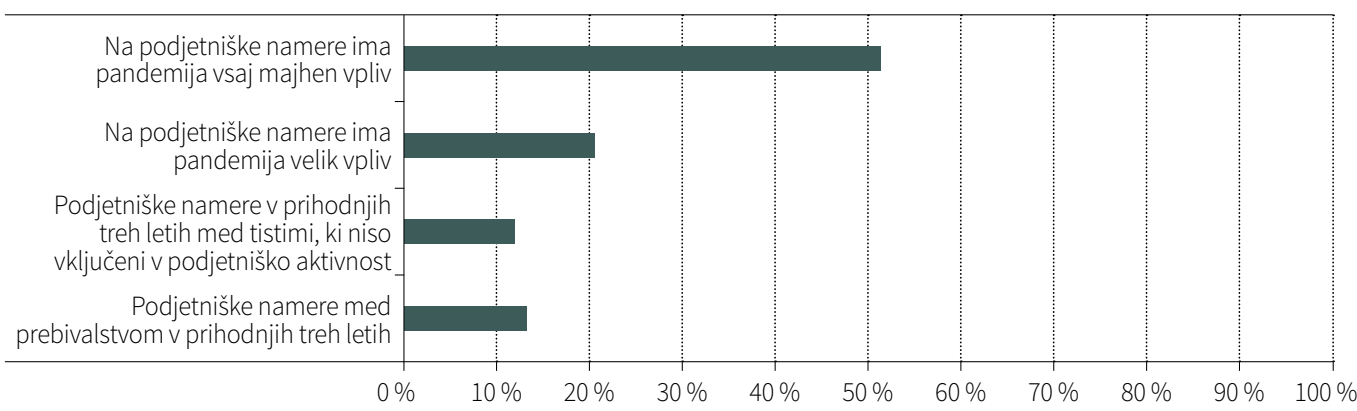

Odstotek odraslega prebivalstva v starosti od 18 do 64 let

GEM Slovenija 2020, APS

Podjetništvoje proces, ki sezačne pri posamezniku, zato GEM v prvi vrsti obravnava posameznike in ocenjuje njihov odnos in dojemanje podjetništva ter njihovo zaznano vključevanje v ustanavljanje in/ali lastništvo in vodenje podjetja. To je pomembno, saj stališča, dejavnosti in ambicije ljudi močno vplivajo na podjetniški proces in njegovo dinamiko. GEM spremlja posameznike v vseh fazah procesa, tudi tiste z ambicijami in nameni po podjetniškem udejstvovanju, med katerimi so nekateri že naredili prve korake za začetek delovanja njihovega podjema, pa tudi tiste, ki so svoja podjetja popeljali med ustaljena, uveljavljena podjetja. V podjetniško aktivni populaciji zajema GEM tudi tiste zaposlene, ki novi podjem začenjajo v okviru svoje redne zaposlitve. Sestavni del podjetniškega procesa je tudi prenehanje podjetniške aktivnosti, bodisi da je to načrtovano ali pa se zgodi zaradi zunanjih vplivov.

V tabeli 2.1 zbirno prikazujemo vrednosti kazalnikov za različne vidike podjetniške aktivnosti v Sloveniji leta 2020 primerjalno z letom poprej in za posamezne proučevane skupine: prebivalstvo v starosti od 18 do 64 let, nastajajoči podjetniki, novi podjetniki, posamezniki v zgodnjih fazah podjetništva (nastajajoči in novi podjetniki), nepodjetniki ter ustaljeni podjetniki. 
Tabela 2.1: GEM-ova preglednica značilnosti podjetništva v Sloveniji, GEM Slovenija 2020, APS

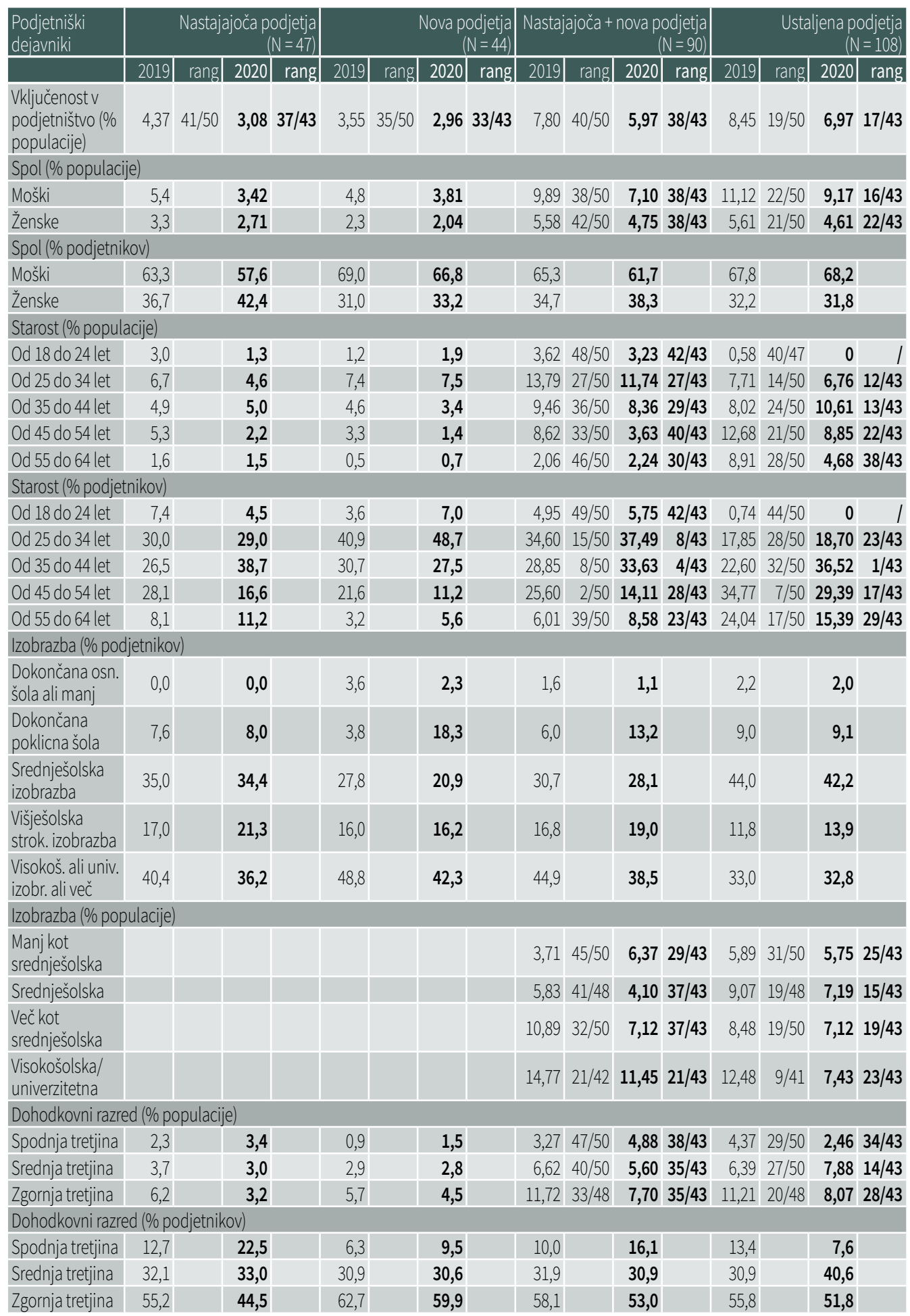




\begin{tabular}{|c|c|c|c|c|c|c|c|c|c|c|c|c|c|c|c|c|}
\hline \multirow[b]{2}{*}{ Podjetniški dejavniki } & \multicolumn{4}{|c|}{ Nastajajoča podjetja } & \multicolumn{4}{|c|}{ Nova podjetja } & \multicolumn{4}{|c|}{$\begin{array}{r}\text { Nastajajoča }+ \text { nova } \\
\text { podjetja }\end{array}$} & \multicolumn{4}{|c|}{ Ustaljena podjetja } \\
\hline & 2019 & rang & 2020 & rang & 2019 & rang & 2020 & rang & 2019 & rang & 2020 & rang & 2019 & rang & 2020 & rang \\
\hline $\begin{array}{l}\text { Ustvariti razliko v } \\
\text { svetu }\end{array}$ & 53,46 & $20 / 50$ & 53,90 & $13 / 43$ & 41,90 & $30 / 50$ & 36,44 & $25 / 43$ & 48,19 & $23 / 50$ & 44,60 & $19 / 43$ & 38,75 & $23 / 50$ & 52,74 & $11 /$ \\
\hline $\begin{array}{l}\text { Ustvariti premoženje } \\
\text { oziroma večji dohodek }\end{array}$ & 50,99 & $27 / 50$ & 42,45 & $34 / 43$ & 44,15 & $36 / 50$ & 38,33 & $38 / 43$ & 47,05 & $35 / 50$ & 39,71 & $38 / 43$ & 30,83 & $42 / 50$ & 33,41 & $35 / 43$ \\
\hline $\begin{array}{l}\text { Nadaljevati družinsko } \\
\text { podjetje/tradicijo }\end{array}$ & 26,37 & $34 / 50$ & 22,24 & $27 / 43$ & 18,41 & $44 / 50$ & 22,76 & $33 / 43$ & 23,17 & $39 / 50$ & 21,60 & $29 / 43$ & 33,83 & $35 / 50$ & 47,72 & $7 / 43$ \\
\hline $\begin{array}{l}\text { Preživeti, saj so službe } \\
\text { redke }\end{array}$ & 61,51 & $30 / 50$ & 70,17 & $21 / 43$ & 58,07 & $31 / 50$ & 74,94 & $16 / 43$ & 60,12 & $30 / 50$ & 72,19 & $20 / 43$ & 71,01 & $27 / 50$ & 77,56 & $14 / 43$ \\
\hline
\end{tabular}

\begin{tabular}{|l|c|c|c|r|r|r|r|r|}
\hline \multirow{2}{*}{ Nagnjenost k rasti (\% podjetnikov) } & \multicolumn{4}{|c|}{ Nastajajoča + nova podjetja } & \multicolumn{4}{c|}{ Ustaljena podjetja } \\
\cline { 2 - 10 } & 2019 & rang & 2020 & rang & 2019 & rang & 2020 & rang \\
\hline $\begin{array}{l}\text { Zaposlovanje - porast za najmanj 10 delovnih } \\
\text { mest in hkrati za najmanj 50\% v petih letih }\end{array}$ & 14,78 & $37 / 50$ & $\mathbf{1 6 , 7 9}$ & $\mathbf{2 4 / 4 3}$ & 3,89 & $32 / 50$ & $\mathbf{2 , 7 6}$ & $\mathbf{3 8 / 4 3}$ \\
\hline $\begin{array}{l}\text { Izvoz - več kot 50 \% prihodka je ustvarjenega } \\
\text { zunaj države }\end{array}$ & 1,18 & $16 / 50$ & $\mathbf{0 , 8 7}$ & $\mathbf{1 6 / 4 3}$ & 0,76 & $13 / 50$ & $\mathbf{1 , 0 1}$ & $\mathbf{3 / 4 3}$ \\
\hline
\end{tabular}

\begin{tabular}{|c|c|c|c|c|c|c|c|c|c|c|c|c|}
\hline \multirow[b]{2}{*}{ Podjetniški dejavniki* } & \multicolumn{2}{|c|}{$\begin{array}{r}\text { Nastajajoči } \\
\text { podjetniki }\end{array}$} & \multicolumn{2}{|c|}{$\begin{array}{r}\text { Novi } \\
\text { podjetniki }\end{array}$} & \multicolumn{2}{|c|}{$\begin{array}{r}\text { Ustaljeni } \\
\text { podjetniki }\end{array}$} & \multicolumn{4}{|c|}{$\begin{array}{r}\% \text { prebivalstva v starosti } \\
\text { od } 18 \text { do } 64 \text { let }\end{array}$} & \multicolumn{2}{|c|}{ Nepodjetniki } \\
\hline & 2019 & 2020 & 2019 & 2020 & 2019 & 2020 & 2019 & rang & 2020 & rang & 2019 & 2020 \\
\hline Razpoznavanje poslovnih priložnosti & 57,7 & 61,65 & 60,3 & 45,28 & 51,0 & 35,39 & 47,59 & $31 / 50$ & 42,03 & $29 / 43$ & 46,4 & 41,73 \\
\hline Podjetniške namere v prihodnjih treh letih & & 50,81 & & 12,28 & & 13,58 & 16,59 & $35 / 50$ & 13,27 & $32 / 43$ & 15,0 & 11,94 \\
\hline $\begin{array}{l}\text { Podjetniške namere v prihodnjih treh letih } \\
\text { tistih, ki niso vključeni v podjetništvo }\end{array}$ & & & & & & & & & 11,95 & $30 / 43$ & & \\
\hline \multicolumn{13}{|c|}{ Podjetniška zmogljivost - dojemanje kulturne podpore } \\
\hline Egalitarizem & 84,9 & 73,24 & 74,1 & 79,56 & 74,5 & 72,34 & 81,15 & $4 / 49$ & 81,21 & $3 / 43$ & 82,0 & 82,19 \\
\hline Poklicna izbira & 63,0 & 66,37 & 50,6 & 63,24 & 62,2 & 64,28 & 63,45 & $32 / 50$ & 68,67 & $20 / 43$ & 64,0 & 69,38 \\
\hline Spoštovanje podjetniškega poklica & 83,3 & 92,86 & 86,3 & 91,30 & 65,0 & 75,44 & 84,04 & $12 / 50$ & 85,06 & $9 / 43$ & 85,8 & 85,39 \\
\hline Odnos medijev & 75,7 & 83,20 & 82,8 & 76,66 & 75,6 & 78,56 & 82,51 & $4 / 50$ & 81,30 & $6 / 43$ & 83,3 & 81,54 \\
\hline \multicolumn{13}{|l|}{ Podjetniška zmogljivost - samozaupanje* } \\
\hline Znanje in veščine & 95,4 & 98,12 & 98,1 & 67,51 & 86,8 & 90,61 & 57,46 & $28 / 50$ & 59,40 & $23 / 43$ & 50,5 & 54,13 \\
\hline Strah pred neuspehom & 34,0 & 28,36 & 23,3 & 32,05 & 29,7 & 33,52 & 43,71 & $26 / 50$ & 48,22 & $15 / 43$ & 46,2 & 50,68 \\
\hline $\begin{array}{l}\text { Strah pred neuspehom med tistimi, ki } \\
\text { razpoznavajo poslovne priložnosti }\end{array}$ & & & & & & & & & 43,83 & $18 / 43$ & & \\
\hline
\end{tabular}

*Prikazan je odstotek tistih, ki so odgovorili z da, v celoti vseh, ki so na vprašanje odgovoriliz da ali ne.

V nadaljnjih poglavjih te monografije vse te vidike podjetniške aktivnosti tudi podrobneje analiziramo. 


\section{Podjetniška zmogljivost odraslega prebivalstva in zaznavanje odnosa do podjetništva v družbi}

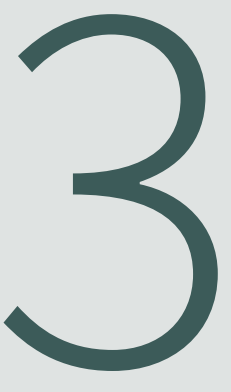

\section{Ključna spoznanja}

- V Sloveniji je v letu 2020 v povprečju nekaj manj odstotkov ljudi kot v predhodnem letu zaznavalo obetavne poslovne priložnosti v svojem okolju, 42,03\%, kar je dobrih $5 \%$ manj kot leto poprej. Še vedno pa to pomeni, da se je zaznavanje poslovnih priložnosti v zadnjih petih letih v Sloveniji v povprečju podvojilo (20,5 \% v letu 2015). Hkrati jih v povprečju več kot polovica $(62,03 \%)$ meni, da je enostavno ustanoviti svoje podjetje.

- Delež odraslega prebivalstva, ki meni, da ima potrebno znanje, izkušnje in sposobnosti za podjetništvo, je v povprečju 59,40 \%, kar je še nekoliko več kot leta poprej in je tudi nad povprečjem evropskih držav, ki je v letu 2020 znašalo $52,64 \%$.

- V Sloveniji je bil v letu 2020 strah pred neuspehom med ljudmi prisoten v povprečju v nekoliko večji meri (48,22 \%) kot v letu 2019 (43,71\%).

- V Sloveniji namerava v povprečju slabih $12 \%$ ljudi, ki še niso vključeni v nobeno obliko podjetniške aktivnosti, stopiti na podjetniško pot v naslednjih treh letih. To uvršča Slovenijo nekoliko nad evropsko povprečje, ki znaša 10,65 \%.

- V Sloveniji je ponovno porasel delež ljudi, ki menijo, da je podjetništvo dobra izbira kariere; ta delež znaša 68,67 \% in uvršča Slovenijo na šesto mesto v evropskem merilu.

- Slovenija se uvršča v vrh evropskih držav po deležu ljudi, ki menijo, da so uspešni podjetniki v slovenski družbi spoštovani (85,06 \%), kar pomeni, da slovenska družba spoštuje in priznava zahtevnost podjetniškega poklica in ga nagrajuje z visoko stopnjo družbenega spoštovanja.

- V Sloveniji je bila tudi v letu 2020 zaznana visoka stopnja podpore podjetništvu v medijih v povprečju $81,30 \%$ ljudi meni, da je v medijih v Sloveniji pogosto mogoče zaslediti zgodbe o uspešnih novih podjetnikih, kar uvršča Slovenijo tudi v letu 2020 v sam vrh lestvice sodelujočih evropskih držav. 
Na oblikovanje podjetniških namer in vključevanje posameznikov v podjetništvo vplivajo po eni strani posameznikove lastnosti in njegove zaznave lastnih sposobnosti in podjetniških kompetenc, po drugi strani pa tudi posameznikove zaznave okolja, v katerem namerava svoj podjem izvesti. Odločitev za podjetništvo kot osebna odločitev posameznika je tako povezana s tistim specifičnim okoljem in stopnjo razvoja podjetniškega ekosistema, ko želi posameznik svojo podjetniško namero udejanjiti ali pa jo je že začel udejanjati. Raziskave kažejo, da so med dejavniki, ki vplivajo na podjetniško odločitev nastajajočih podjetnikov, podjetniška izobrazba, družinsko ozadje (družinsko podjetništvo), pozitivno zaznavanje podjetniškega ekosistema in z njim povezano razpoznavanje poslovnih priložnosti, oblikovane podjetniške namere ter različni vidiki samozaupanja v zadostne podjetniške kompetence (Nguyen, 2020).

Podjetniške namere so pomemben predhodnik dejanske podjetniške aktivnosti. Pri tem imajo podjetniške priložnosti osrednje mesto. Raziskave kažejo, da podjetniške priložnosti pomembno spodbujajo rojevanje podjetniških namer (Ramawati et al., 2020).

Vokviru raziskave GEM tako v APS identificiramo zaznave ljudi o tem, ali obstajajo dobre priložnosti za začetek novega podjetja v lokalnem okolju. Pomemben dejavnik pri odločitvi, ali naj začnejo s podjetniško potjo ali ne, in pri uspehu ter dolgi življenjski dobi začetega podjema je tudi to, ali in v kakšnem obsegu se posamezniki vidijo kot potencialni podjetniki. Da bi to ocenili, analiziramo, ali se anketiranci strinjajo, da imajo osebno znanje, spretnosti in izkušnje za začetek novega podjetja in ali bi jih od ustanovitve novega podjetja oziroma podjema odvrnil strah, da to ne bi uspelo.

Ugotovitve raziskav kažejo tudi na pomen družbenih vrednot in celotnega podjetniškega ekosistema (Nguyen, 2020) pri vključevanju ljudi v podjetništvo. Kulturne in družbene norme v nekaterih gospodarstvih pomembno spodbujajo podjetniško aktivnost, v drugih gospodarstvih pa delujejo zavirajoče, na primer z morebitnim družbenim obsojanjem podjetniškega neuspeha. Ker so posamezniki torej del širšega kulturnega in družbenega okolja, ki vpliva na njihove podjetniške namere in nato na podjetniške odločitve in jih sooblikuje, v okviru raziskave GEM proučujemo tudi zaznavanje družbenih vrednot o podjetništvu.

V tabeli 1 v prilogi P3 so za vse sodelujoče države GEM v letu 2020 prikazani kazalniki, ki se nanašajo na zgoraj opredeljene vidike samozaznavanja podjetniške zmogljivosti ljudi in zaznavanja družbenih vrednot o podjetništvu. 


\subsection{Samozaznavanje in dojemanje podjetništva z vidika posameznika}

V tabeli 3.1 prikazujemo nekatere vidike samozaznavanja in dojemanja podjetništva v Sloveniji v letu 2020 primerjalno z izbranimi skupinami držav, ki sodelujejo v GEM.

Tabela 3.1: Elementi podjetniške zmogljivosti, GEM Slovenija 2020, APS

\begin{tabular}{|l|r|r|r|r|}
\hline & \multicolumn{2}{|c|}{$\begin{array}{r}\text { Slovenija } \\
\text { Podjetniška zmogljivost - samozaznavanje in dojemanje podjetništva z vidika posameznika }\end{array}$} \\
\hline Zaznavanje poslovnih priložnosti & $42,03 \%$ & $50,51 \%$ & $46,67 \%$ & $39,52 \%$ \\
\hline $\begin{array}{l}\text { Zaznana enostavnost ustanovitve lastnega } \\
\text { podjetja }\end{array}$ & $62,03 \%$ & $54,20 \%$ & $55,46 \%$ & $53,76 \%$ \\
\hline $\begin{array}{l}\text { Zaznano znanje, izkušnje in spodobnosti za } \\
\text { podjetništvo }\end{array}$ & $59,40 \%$ & $61,02 \%$ & $57,57 \%$ & $52,64 \%$ \\
\hline $\begin{array}{l}\text { Zaznavanje strahu pred neuspehom med } \\
\text { tistimi, ki zaznavajo poslovne priložnosti }\end{array}$ & $43,83 \%$ & $41,04 \%$ & $43,24 \%$ & $42,13 \%$ \\
\hline $\begin{array}{l}\text { Podjetniške namere med tistimi, ki niso } \\
\text { vključeni v podjetniško aktivnost }\end{array}$ & $11,95 \%$ & $27,30 \%$ & $20,66 \%$ & $10,65 \%$ \\
\hline
\end{tabular}

Slika 3.1. Elementi podjetniške zmogljivosti, Slovenija in povprečje evropskih držav
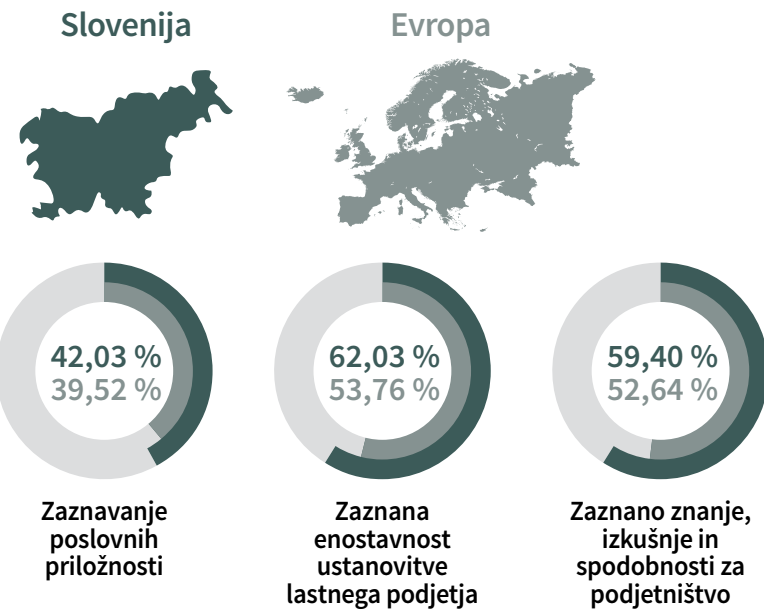

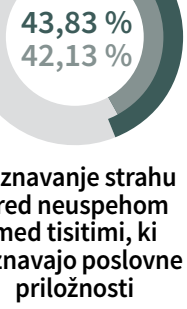

$43,83 \%$

$11,95 \%$ $10,65 \%$

Podjetniške namere med tistimi, ki niso vključeni v podjetniško aktivnost

V Sloveniji je v letu 2020 nekaj manj odstotkov ljudi kot v predhodnem letu zaznavalo obetavne poslovne priložnosti v svojem okolju 42,03 \%, kar je dobrih $5 \%$ manj kot leto poprej. Še vedno pa to pomeni, da se je zaznavanje poslovnih priložnosti v zadnjih petih letih v Sloveniji v povprečju podvojilo (20,5 \% v letu 2015). Kot prikazujemo na sliki 3.2, se Slovenija na lestvici 18 sodelujočih 
evropskih držav v raziskavi GEM po tem kazalniku v letu 2020 uvršča na sredino in nad letošnje evropsko povprečje, ki znaša 39,52 \%. Čeprav skupina sodelujočih evropskih držav ni povsem enaka kot v predhodnem letu, pa ugotavljamo, da se je evropsko povprečje zmanjšalo za dobrih 10 odstotnih točk (povprečje evropskih držav v 2019 je bilo 50,17 \%).

\section{Slika 3.2: Zaznavanje poslovnih priložnosti (v evropskih državah GEM)}

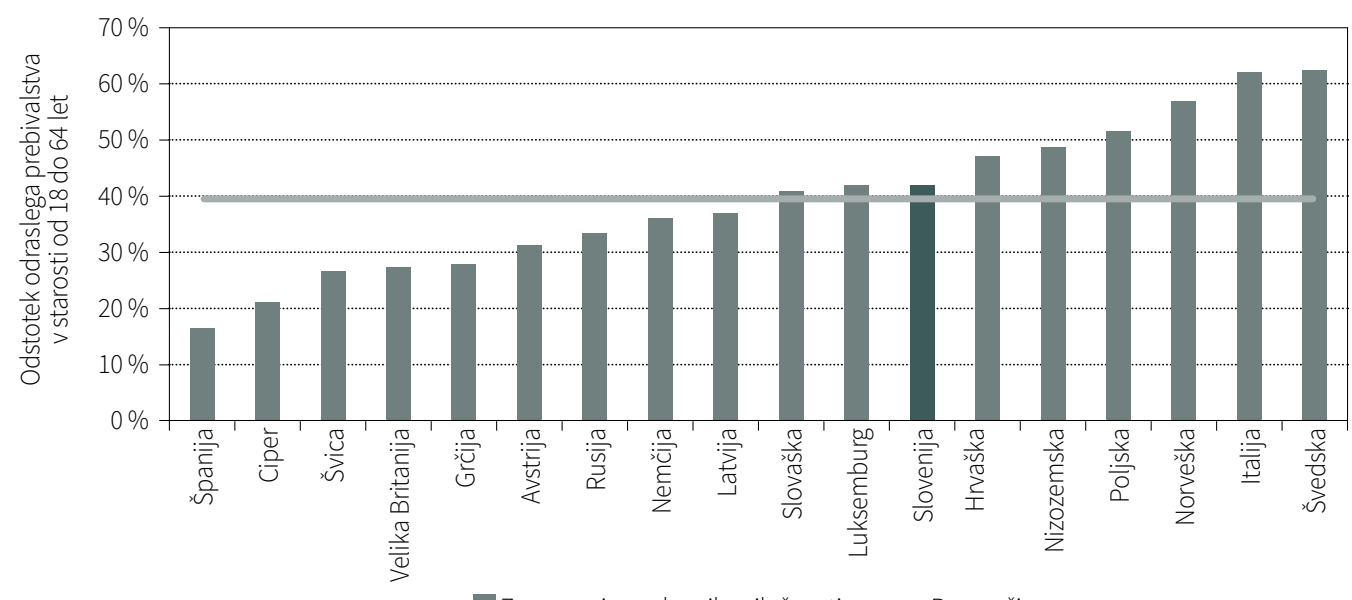

GEM Slovenija 2020, APS

V evropskem kontekstu je določen vidik podjetniškega ekosistema mogoče oceniti tudi preko zaznav ljudi o tem, kako enostavno je ustanoviti podjetje. Kot ugotavlja raziskava GEM (Bosma et al., 2020), obstaja povezava med dojemanjem priložnosti in zaznano enostavnostjo ustanovitve podjetja. To lahko potrdimo tudi za evropske države, saj za leto 2020 za evropske države velja visoka stopnja pozitivne povezanosti med obema značilnostma (korelacijski koeficient znaša 0,584, p<0,01). Povezanost med obema značilnostma prikazujemo na sliki 3.3. Koordinatni sistem je razdeljen na štiri dele glede na vrednost mediane (mediana za odstotek ljudi, ki zaznavajo poslovne priložnosti, je 40,91 \%, mediana za odstotek ljudi, ki menijo, da je enostavno ustanoviti podjetje, pa 55,54\%). Slovenija se uvršča $\vee$ zgornjo polovico držav po obeh značilnostih - v Sloveniji velja, da manj kot polovica prebivalstva v svojem okolju zaznava dobre poslovne priložnosti za ustanovitev podjetja (42,03 \%) in več kot polovica (62,03 \%) jih meni, da je enostavno ustanoviti svoje podjetje. Najvišje stopnje pri zaznavanju enostavnosti pri ustanovitvi podjetja in hkrati najvišje stopnje zaznavanja poslovnih priložnosti so na Švedskem, v Italiji, na Norveškem in na Nizozemskem, najnižje pa v Španiji. V nekaterih državah ljudje sicer v večji meri zaznavajo enostavnost ustanovitve podjetja kot v Sloveniji, zaznavanje poslovnih priložnosti pa je kljub temu majhno, na primer v Veliki Britaniji. Na drugi strani pa je razpoznavanje poslovnih priložnosti v nekaterih okoljih veliko, čeprav je zaznana enostavnost ustanovitve novega podjema relativno majhna, na primer na Slovaškem ali na Hrvaškem, kar pomeni, da je poslovnih priložnosti v okolju sicerveliko, pri njihovem udejanjanju pa je relativno veliko ovir, ki jih mora posameznik, ki se podaja $\checkmark$ podjetništvo, premagati. Pri tem ne gre samo za ovire, ki izhajajo iz družbenega konteksta in podjetniškega ekosistema, ampak v enaki meri tudi za ovire, ki izhajajo iz samega posameznika. 
Slika 3.3: Zaznavanje poslovnih priložnosti in zaznana enostavnost ustanoviti podjetje (v evropskih državah GEM)

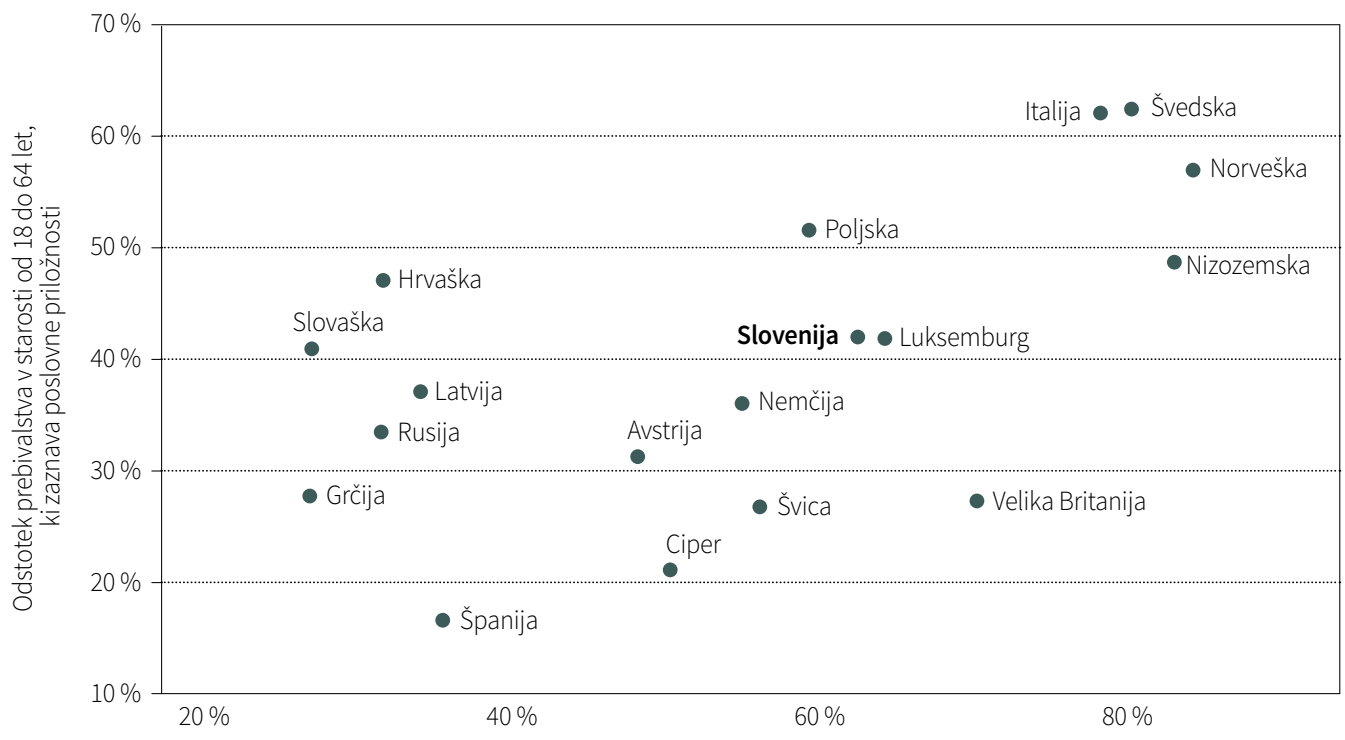

Odstotek prebivalstva v starosti od 18 do 64 let, ki meni, da je enostavno ustanoviti podjetje

GEM Slovenija 2020, APS

Dovzetnostza zaznavanje priložnosti v okolju in njihovo identificiranje kot obetavnih za podjetniško aktivnost sta lahko odvisna od posameznikovega samozaznavanja lastnih podjetniških kompetenc, ki so seveda povezane tudi z njegovimi prepričanji o tem, kakšne kompetence podjetnik potrebuje. Takšen razmislek je zagotovo povezan s tem, ali posameznik meni, da ima potrebno znanje, izkušnje in sposobnosti za podjetništvo. Na sliki 3.4 prikazujemo delež odraslega prebivalstva, ki meni, da ima potrebno znanje, izkušnje in sposobnosti za podjetništvo, po tej značilnosti pa se je prebivalstvo Slovenije v evropskem merilu vedno uvrščalo visoko. Tako je bilo tudi v letu 2020, ko ocenjujemo, da je ta odstotek enak 59,40 \%, kar je nekoliko več kot leta poprej in je tudi nad povprečjem evropskih držav, ki je v letu 2020 znašalo 52,64%. Na najvišja mesta na lestvici so se med evropskimi državami povzpele Hrvaška, Italija in Poljska, vse tri z več kot 60 \% prebivalstva, ki meni, da poseduje te podjetniške zmogljivosti. Slovenija se na evropski lestvici tako umešča na četrto mesto. 
Slika 3.4: Zaznano podjetniško znanje, izkušnje in sposobnosti (v evropskih državah GEM)

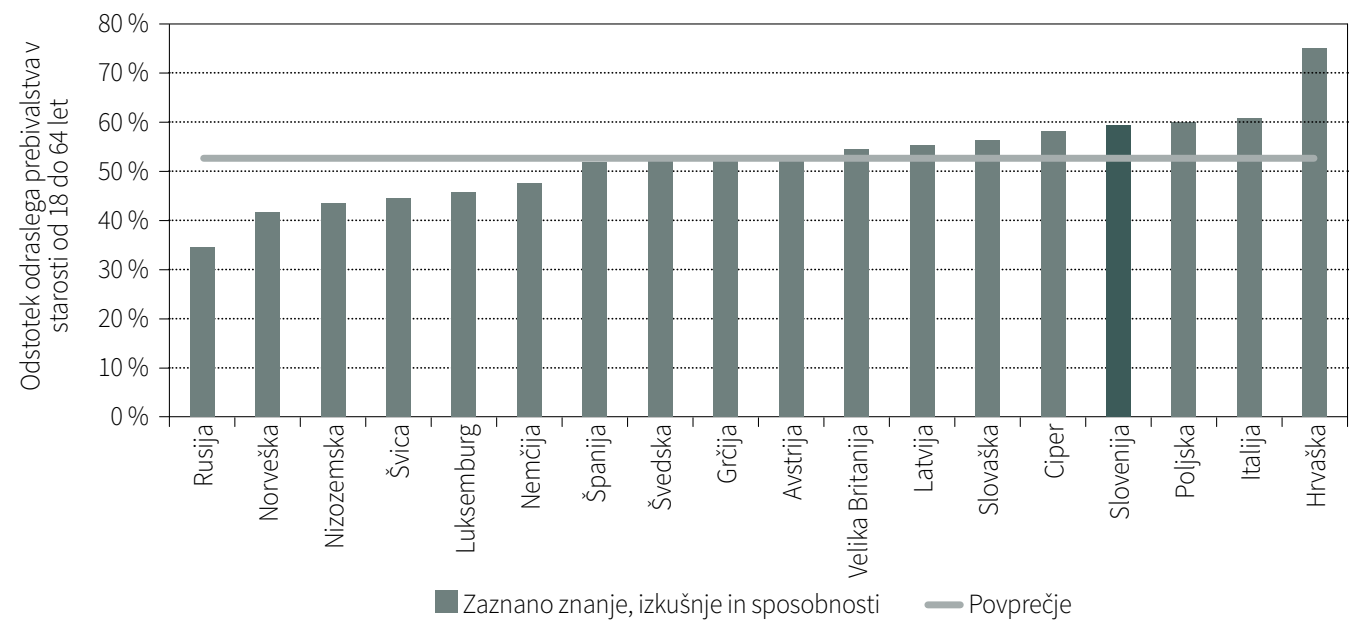

GEM Slovenija 2020,APS

Raziskave kažejo, da so namere vključevanja v podjetništvo močno negativno povezane z zaznanim strahom pred neuspehom (Vodă et al., 2020), rezultati pa tudi kažejo, da je strah pred neuspehom v povprečju manjši v okoljih z družinsko tradicijo podjetništva in tam, kjer je razvito podjetniško mreženje. V okoljih, kjer je strah pred neuspehom močno izražen, lahko hromi tako samo zaznavanje kot tudi izkoriščanje poslovnih priložnosti. Zavedamo se, da je strah pred neuspehom sicer sestavni del podjetniške izkušnje (Cacciotti et al., 2020), vendar pa je njegov vpliv v zgodnjih fazah podjetniške aktivnosti lahko pomembnejši kot takrat, ko obstaja kot sestavni del podjetniške prakse.

Na sliki 3.5 lahko vidimo, da je razkorak med razpoznavanjem poslovnih priložnosti in strahom pred neuspehom v nekaterih državah velik, največji v Španiji, kjer je delež prebivalstva, ki zaznava poslovne priložnosti, najmanjši med sodelujočimi evropskimi državami, hkrati pa je strah pred neuspehom med ljudmi močno zasidran. V Sloveniji je sicer razlika med obema deležema relativno majhna, a vendar je strah pred neuspehom prisoten $v$ večji meri $(48,22 \%$ ljudi) kot zaznavanje obetavnih poslovnih priložnosti (42,03\%). Med evropskimi državami je sicer le pet takšnih, v katerih delež prebivalstva, ki zaznava poslovne priložnosti, presega delež tistih, ki jih strah pred neuspehom odvrača od ustanovitve lastnega podjetja, to so Švedska, Italija, Norveška, Nizozemska in Poljska. 
Slika 3.5: Strah pred neuspehom ter zaznavanje poslovnih priložnosti (v evropskih državah GEM)

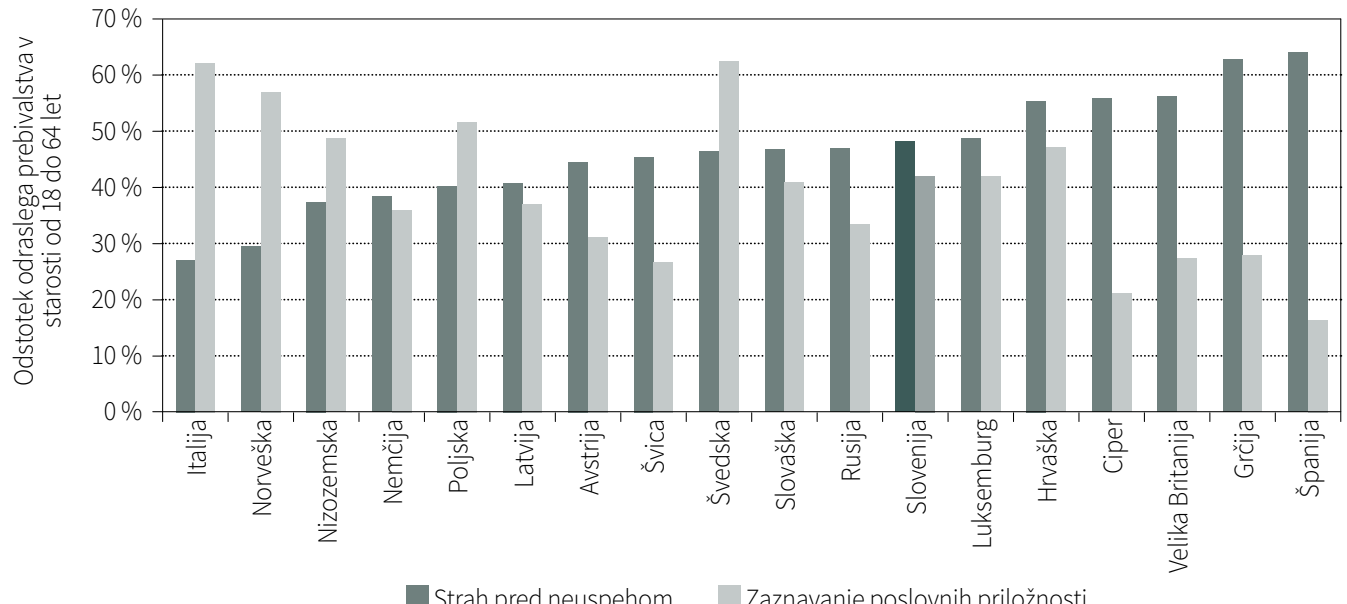

GEM Slovenija 2020, APS

Raziskovanje podjetniških namer se povezuje s področjem socialne psihologije, ki podjetniške namere analizira v povezavi s prihodnjim podjetniškim vedenjem. Tovrstne raziskave temeljijo na Ajzenovi teoriji načrtovanega vedenja, $v$ njih pa proučujejo tudi raznovrstne zunanje dejavnike, ki vplivajo na oblikovanje podjetniških namer in prihodnje podjetniško vedenje (Gieure et al., 2020). Raziskave kažejo, da so oblikovane podjetniške namere predhodnik dejanske odločitve posameznika, da se vključi v podjetniško aktivnost (Ramawati et al., 2020), kljub temu da mnoge podjetniške namere ostanejo neuresničene.

Kot smo že grafično pokazali v 2. poglavju, proučujemo v okviru raziskave GEM podjetniške namere z več različnih vidikov, v letu 2020 pa smo jih tudi dodatno osvetlili še z vidika vpliva pandemije. Osrednja mera podjetniških namer je v okviru GEM APS delež ljudi, ki so pritrdilno odgovorili na vprašanje, ali nameravajo $v$ prihodnjih treh letih začeti nov posel. V Sloveniji so v obdobju 2017-2019 podjetniške namere ljudi v povprečju ostajale na približno enaki ravni: v letu 2017 je bilo odraslih posameznikov, ki razmišljajo o tem, da bi v prihodnjih treh letih ustanovili podjetje, 16,7 \%, v letu 2018 16,30 \%, v letu 2019 pa 16,6 \%. V letu 2020 je ta delež upadel na 13,2 \% odraslega prebivalstva.

Prebivalci Slovenije v povprečju v manjši meri kot prebivalci drugih evropskih držav ocenjujejo, da ima pandemija covida-19 velik vpliv na podjetniške namere ljudi, kar prikazujemo na sliki 3.6. V Sloveniji smo anketiranje prebivalstva izvedli v času prvega vala pandemije, nekatere druge države pa so prav zaradi pandemije anketiranje izvedle šele jeseni, kar pomeni, da bi bil v jesenskem, drugem valu negativen vpliv pandemije v Sloveniji morda tudi močneje izražen. 
Slika 3.6: Zaznavanje velikega vpliva pandemije na podjetniške namere - evropske države GEM

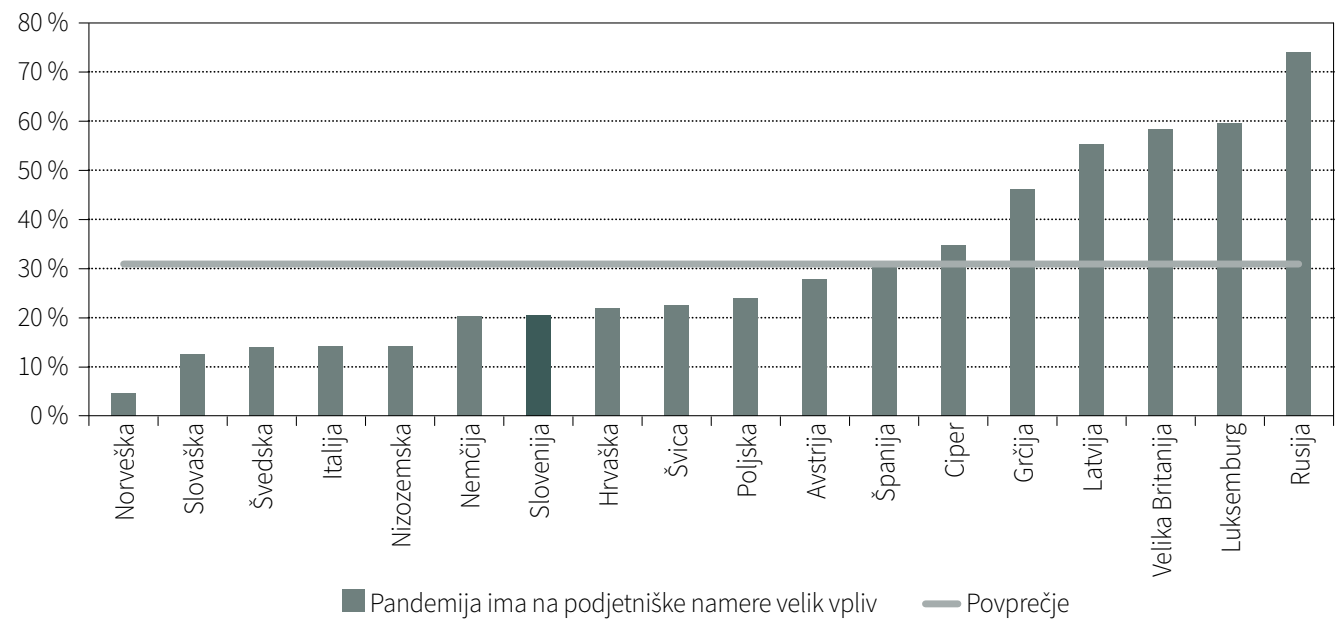

GEM Slovenija 2020,APS

Da ima pandemija vsaj majhen vpliv na podjetniške namere ljudi, pa misli v povprečju 59,1\% odraslega prebivalstva v Evropi (netehtano povprečje), v Sloveniji pa nekaj več kot 50 \% (slika 3.7). $\checkmark$ obeh primerih je na vrhu lestvice Rusija, kjer celo več kot $90 \%$ prebivalstva v povprečju meni, da ima pandemija vsaj majhen vpliv na podjetniške namere, več kot $70 \%$ pa, da je ta vpliv velik. V obeh primerih Rusiji na lestvici sledijo Latvija, Velika Britanija in Luksemburg. Najmanjši zaznani vpliv pandemije izražajo na Norveškem.

Slika 3.7: Zaznavanje vsaj majhnega vpliva pandemije na podjetniške namere - evropske države GEM

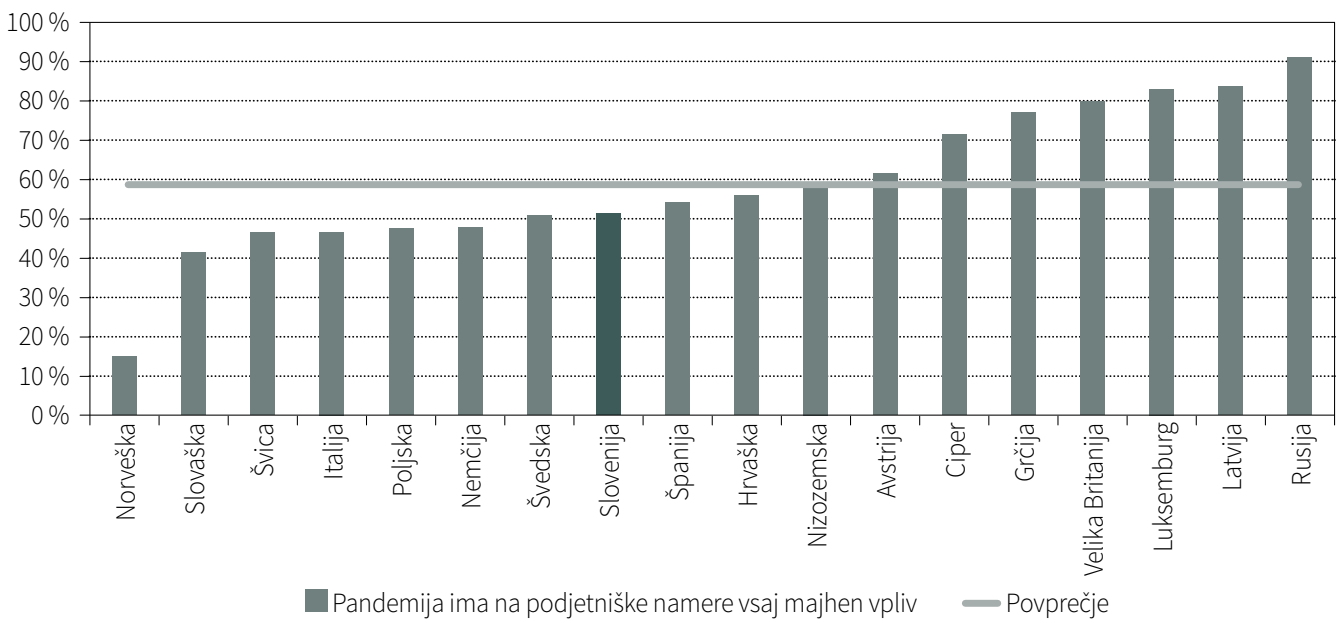

GEM Slovenija 2020, APS

V okviru raziskave GEM pridobimo tudi informacijo o tem, kolikšen delež ljudi, ki se sicer še ne ukvarjajo s podjetništvom, poroča o podjetniških namerah. V Sloveniji namerava slabih 12 \% ljudi, ki še niso vključeni v nobeno obliko podjetniške aktivnosti, stopiti na podjetniško pot v naslednjih 
treh letih. To uvršča Slovenijo malo nad evropsko povprečje, ki znaša 10,65 \%, na 6. mesto, kot prikazujemo na sliki 3.8. Na samem vrhu so sicer Hrvaška (24,27 \%), Ciper (20,5 \%) in Latvija (17,2 \%). Na drugem koncu evropske lestvice, med gospodarstvi, kjer je delež prebivalstva z izraženimi podjetniškimi namerami najmanjši, najdemo Italijo (4,51 \%), Avstrijo (4,05 \%) in Poljsko (4,74 \%). Za posamezne države so značilni nasprotujoči si vzorci: medtem ko so Italija, Norveška in tudi Poljska na repu evropske lestvice glede na podjetniške namere, pa prebivalstvo $\vee$ teh državah izkazuje zelo visoko stopnjo zaznavanja podjetniških priložnosti in tudi zaznane enostavnosti ustanovitve podjetja (slika 3.3), kar kaže na to, da so dejavniki, ki vodijo do izoblikovanih podjetniških namer, raznoliki in večplastni in jih je mogoče iskati tudi v širšem kulturnem in družbenem okolju, ki ga opisujemo v naslednji točki.

Slika 3.8: Podjetniške namere med tistimi, ki niso vključeni v nobeno podjetniško aktivnost (vevropskih državah GEM)

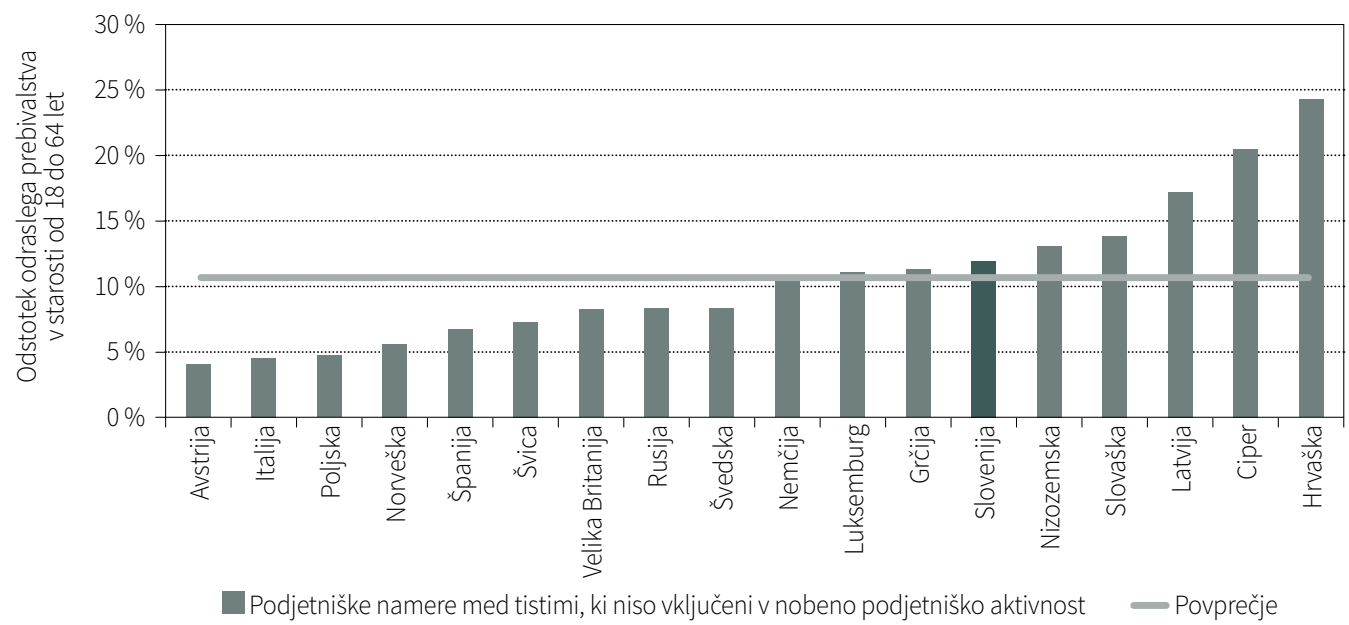

GEM Slovenija 2020, APS

Zaključimo lahko, da je Slovenija po večini elementov podjetniške zmogljivosti povprečna evropska država (večinoma se uvršča nekoliko nad povprečje sodelujočih evropskih držav). Videti dobre priložnosti je ključni prvi korak na podjetniški poti, ki vpliva na podjetniške namere in na kasnejšo vključitev v podjetništvo. Delež ljudi, ki vidijo poslovne priložnosti v svojem okolju, se je v Sloveniji v zadnjih petih letih podvojil, kar zagotovo kaže na krepitev podjetniških zmogljivosti prebivalstva. Res pa je tudi, da se naša država uvršča nad evropsko povprečje tudi glede na razširjeni strah pred podjetniškim neuspehom, vendar pa tudi precej nad evropsko povprečje glede na samozaznane podjetniške kompetence pri ljudeh. Samozavest in zaupanje v sposobnost za uspeh sta zagotovo pozitivna pokazatelja pripravljenosti stopiti na podjetniško pot.

\subsection{Zaznavanje družbenih vrednot o podjetništvu}

V okviru APS proučujemo tudi to, kako ljudje zaznavajo spoštovanje in zaželenost podjetniškega poklica $v$ družbi, pa tudi medijsko podporo podjetništvu. Nastajanje in spreminjanje kulturne in družbene podpore podjetništvu je dolgotrajen proces, v katerem sodeluje veliko različnih deležnikov. Vladni programi in inštitucije z oblikovanjem ukrepov ekonomske politike, ki prispevajo 
h kreiranju v rast usmerjene podjetniške aktivnosti, pozitivno pripomorejo k ugledu podjetništva $\checkmark$ družbi, kar zopet prispeva k oblikovanju pozitivnih družbenih vrednot o podjetništvu ter vpliva na razvoj podjetniškega potenciala $\vee$ družbi (Bosma et al., 2020). Raziskave potrjujejo, da so z nastankom in uspešnostjo različnih oblik podjetniške aktivnosti povezane kulturne in družbene norme oziroma zaznavanje tega, kakšne so prevladujoče kulturne in družbene norme (Huđek et al., 2021).

$\checkmark$ tabeli 3.2 prikazujemo primerjavo Slovenije z izbranimi skupinami držav glede na zaznavanje družbenih vrednot o podjetništvu. V primerjavi z evropskim povprečjem izkazuje odraslo prebivalstvo $v$ Sloveniji veliko zaznano družbeno podporo podjetništvu.

Tabela 3.2: Elementi zaznavanja družbenih vrednot o podjetništvu v družbi, GEM Slovenija 2020, APS

\begin{tabular}{|c|c|c|c|c|}
\hline & Slovenija & GEM & $\begin{array}{r}\text { Visokodohodkovna } \\
\text { gospodarstva }\end{array}$ & $\begin{array}{r}\text { Evropske } \\
\text { države }\end{array}$ \\
\hline \multicolumn{5}{|l|}{ Zaznavanje družbenih vrednot o podjetništvu } \\
\hline Podjetništvo kot karierna pot & $68,67 \%$ & $68,50 \%$ & $64,56 \%$ & $60,80 \%$ \\
\hline Spoštovanje uspešnih podjetnikov v družbi & $85,06 \%$ & $76,73 \%$ & $73,26 \%$ & $69,83 \%$ \\
\hline Medijska podpora podjetništvu & $81,30 \%$ & $69,14 \%$ & $67,48 \%$ & $60,89 \%$ \\
\hline
\end{tabular}

Tako kot v letu 2019 je tudi v letu 2020 veljalo, da je v povprečju v evropskih državah skoraj 70 \% odraslega prebivalstva verjelo, da so uspešni podjetniki v družbi dobro sprejeti, da so spoštovani in uživajo velik ugled. Hkrati pa jih je v povprečju za skoraj 10 odstotnih točk manj menilo, da je podjetništvo ustrezna oziroma zaželena poklicna pot. V povprečju je nekaj več kot 60 \% odraslih prebivalcev tudi menilo, da je uspešno podjetništvo deležno znatne medijske pozornosti. Slovenija se, podobno kot v preteklih letih, po vseh elementih uvršča visoko nad evropsko povprečje.

Slika 3.9: Zaznavanje družbenih vrednot o podjetništvu

\section{Zaznavanje podjetništva kot privlačne karierne izbire}

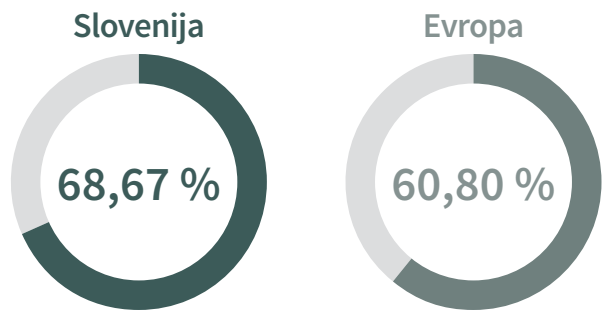

NAJBOLJ POZITIVNE ZAZNAVE: spoštovanje podjetnikov: Saudova Arabija 95,11\% podjetništvo kot karierna pot: Gvatemala $94,26 \%$ medijska podpora: Saudova Arabija 92,93\% NAJBOLJ NEGATIVNE ZAZNAVE: spoštovanje podjetnikov: Hrvaška 53,47 \% podjetništvo kot karierna pot: Avstrija 44,52 \% medijska podpora: Poljska 41,02 \%

V evropskem merilu najmanj pozitivne zaznave o naklonjenosti vrednot kulturnega in družbenega okolja podjetništvu izkazujejo ljudje v Avstriji, kjer jih manj kot polovica (44,52\%) meni, da je podjetništvo zaželena karierna pot, na Hrvaškem, kjer jih 53,47 \% meni, da so uspešni podjetniki v družbi spoštovani, in na Poljskem, kjer samo 41,02 \% ljudi meni, da je v družbi prisotna medijska 
podpora uspešnim podjetniškim zgodbam (hkrati se Hrvaška in Poljska uvrščata visoko nad evropsko povprečje po deležu ljudi, ki visoko ocenjujejo svoje podjetniške kompetence). Zagotovo so podjetniški ekosistemi v narodnih gospodarstvih različni, pa tudi udeležba ustaljenih velikih podjetij v ustvarjanju BDP na prebivalca je različna, na zaznave ljudi o samostojni podjetniški poti pa lahko vpliva tudi stopnja razvitosti notranjega podjetništva.

Kot prikazujemo na sliki 3.10, je v Sloveniji ponovno porasel delež ljudi, ki menijo, da je podjetništvo dobra izbira kariere - na 68,67 \% (63,5 \% v letu 2019). V evropskem merilu se pet držav (med njimi Slovenija) uvršča nad evropsko povprečje, z najvišjim deležem ljudi na Cipru (76,65 \%), v Rusiji (75,30 \%) in v Veliki Britaniji (69,63 \%). Kot je že bilo omenjeno, so na repu lestvice Avstrija ter Švica in Slovaška, kjer manj kot polovica ljudi meni, da je podjetništvo zaželena izbira kariere.

Slika 3.10: Odstotek ljudi, ki menijo, da je podjetništvo primerna izbira karierne poti (v evropskih državah GEM)

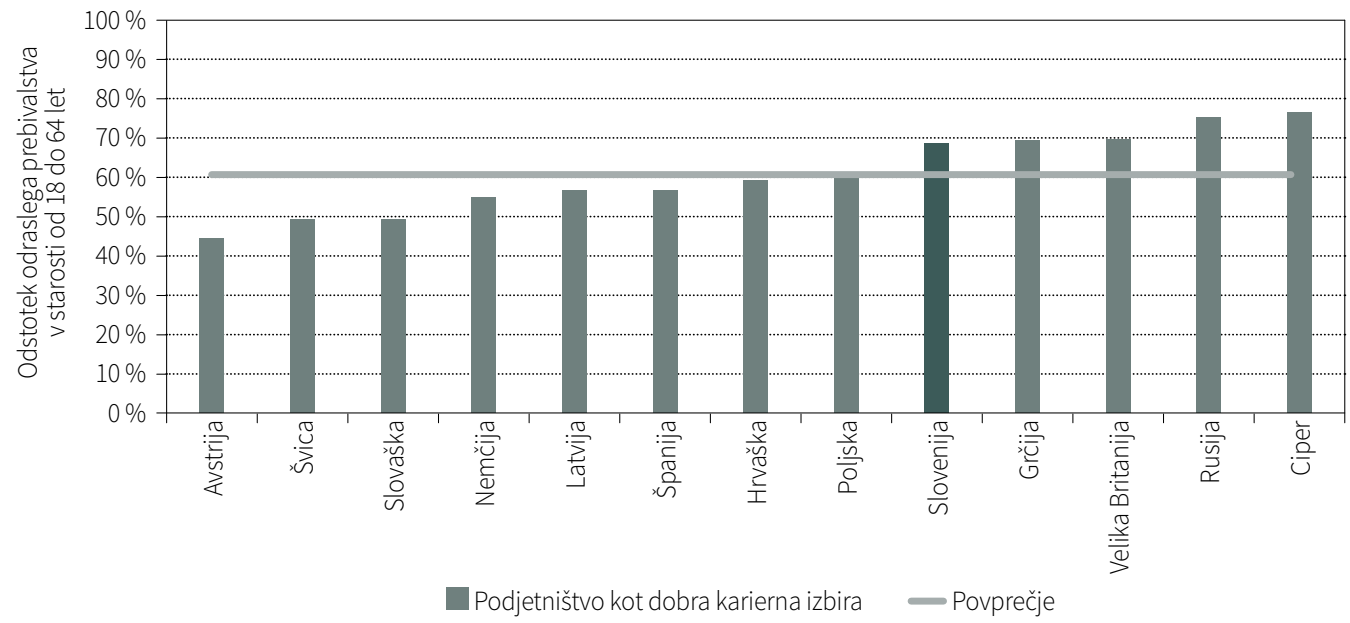

GEM Slovenija 2020, APS

Zaznave o zaželenosti podjetniške karierne poti v posamezni državi so lahko povezane z zaznano težavnostjo oziroma zahtevnostjo podjetniškega poklica, kar se lahko odraža tudi v zaznavah o tem, kako družba spoštuje uspešne podjetnike. Kot prikazujemo na sliki 3.11, se Slovenija po tem kazalniku uvršča v vrh evropskih držav, saj 85,06 \% ljudi meni, da so uspešni podjetniki v slovenski družbi spoštovani, kar pomeni, da slovenska družba spoštuje in priznava zahtevnost podjetniškega poklica in ga nagrajuje z visoko stopnjo družbenega spoštovanja. Na lestvici sledita Nemčija z 81,82 \% in Avstrija z 79,76 \%. Na drugi strani lestvice najdemo Hrvaško (53,47 \%), Poljsko $(60,14 \%)$ in Španijo $(61,14 \%)$. 
Slika 3.11: Odstotekljudi, kimenijo, da so uspešnipodjetnikivdružbispoštovani (vevropskih državah GEM)

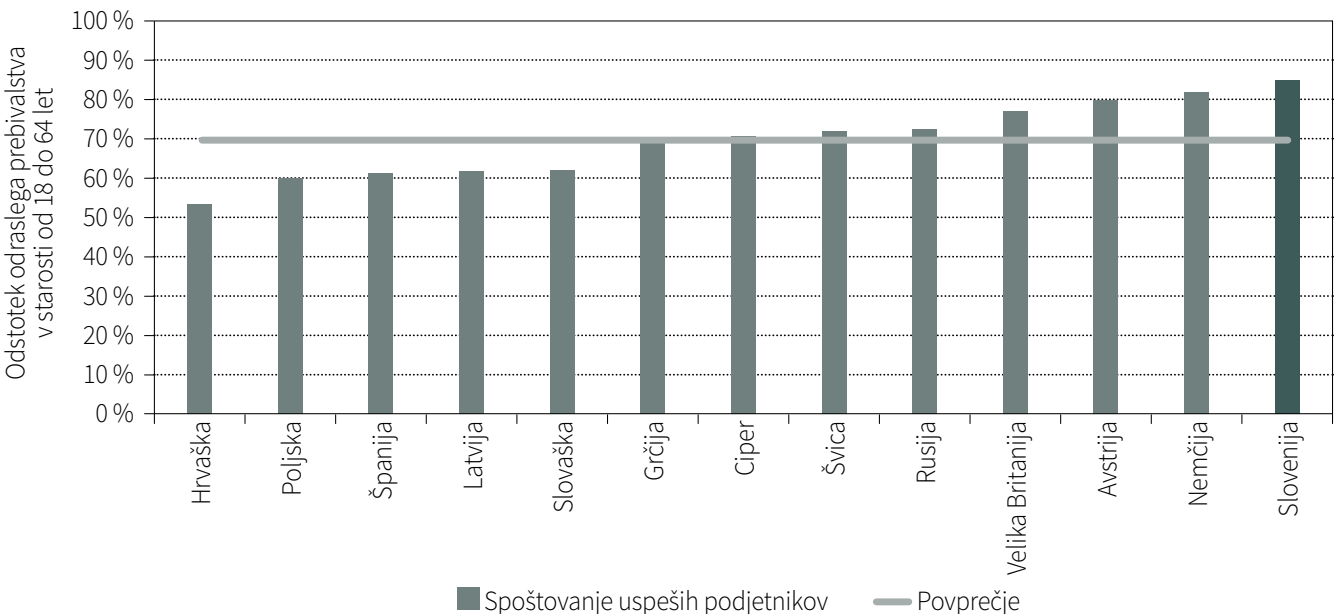

GEM Slovenija 2020,APS

Slika 3.12: Odstotek ljudi, ki zaznavajo medijsko podporo podjetništvu vdružbi (vevropskih državah GEM)

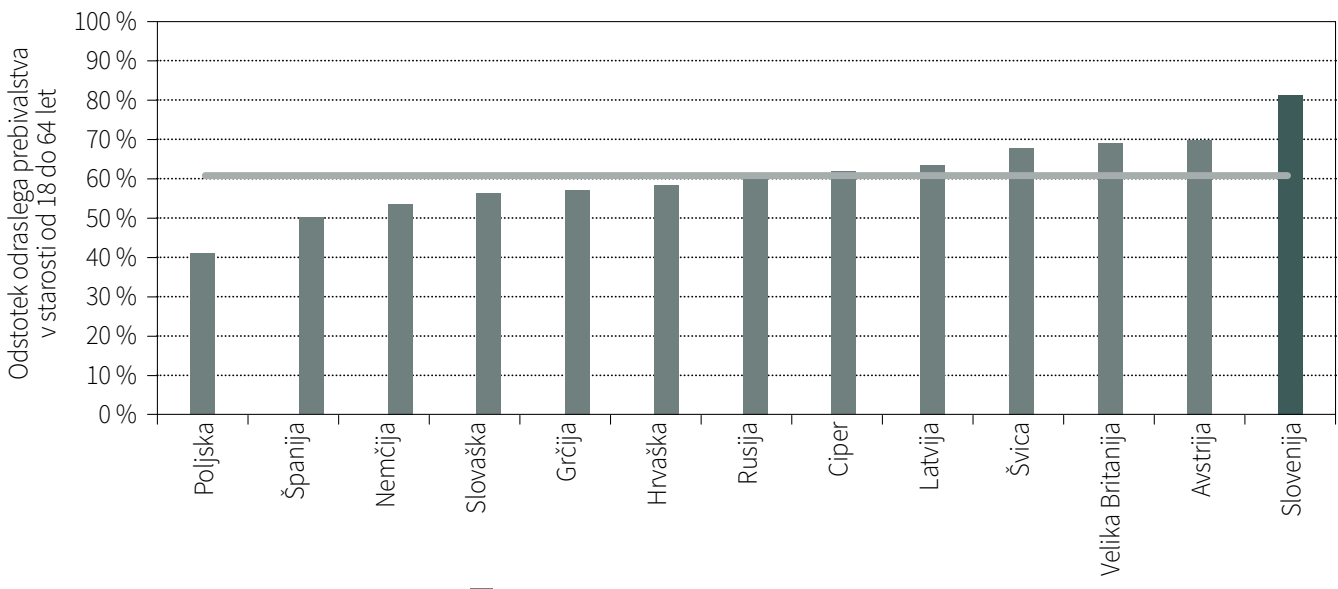

GEM Slovenija 2020, APS

V Sloveniji je bila tudi v letu 2020 zaznana velika podpora podjetništvu v medijih. Potem ko je v letu 2019 v povprečju 82,51 \% ljudi menilo, da je v medijih v Sloveniji pogosto mogoče zaslediti zgodbe o uspešnih novih podjetnikih, je bil v letu 2020 ta odstotek 81,30 \%. Tako je Slovenija tudi v letu 2020 v samem vrhu lestvice sodelujočih evropskih držav, sledita ji Avstrija $(70,03 \%)$ in Velika Britanija (69,21 \%). Na spodnji strani lestvice, z najnižjo zaznano medijsko podporo podjetništvu, so Poljska (41,02\%), Španija (50,21\%) in Nemčija (53,66\%). Zaznano medijsko podporo podjetništvu $v$ evropskih državah GEM prikazujemo na sliki 3.12. 
Ena izmed raziskav na temelju podatkov GEM je pokazala, da mediji vplivajo na družbo na veliko različnih načinov, medijska podpora pa je eden od pomembnih podpornih mehanizmov pri spreminjanju kulturnih in družbenih norm v smeri sprejemanja in podpore podjetništvu $v$ družbi (Bosma et al., 2020). Tudi druge raziskave na tem področju potrjujejo, da je interakcija med kulturnimi in družbenimi normami ter ravnijo podjetništva zapletena in večplastna. Zagotovo ima pri tem pomembno vlogo stopnja gospodarskega razvoja, ki sooblikuje vpliv kulturnih in družbenih norm na podjetništvo. Tako na primer vemo, da je v povprečju pozitivna podjetniška kultura $\vee$ družbi $v$ večji meri prisotna $v$ državah z visokim dohodkom kot $v$ državah z nizkim dohodkom, različni družbeni in kulturni vzorci pa $v$ državah z visokim dohodkom vplivajo na raven podjetništva drugače kot v državah z nizkim dohodkom (Achim et al., 2021). To raznolikost potrjujejo tudi rezultati letošnje raziskave GEM, ki kažejo na raven podjetniških zmogljivosti in nekaterih vidikov učinkovitosti podjetniškega ekosistema v družbi. 



\section{Podjetniška aktivnost odraslega prebivalstva}

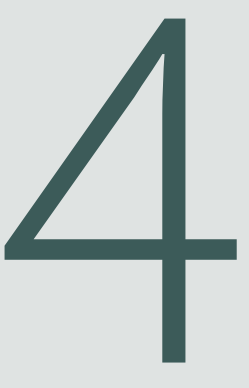

\section{Ključne ugotovitve}

- V letu 2020 smo v Sloveniji zaznali upad celotne zgodnje podjetniške aktivnosti (indeks TEA), saj je s 7,8\% v letu 2019 upadla na $6 \%$. Podoben upad je zaznati tudi v evropskih državah, na globalni ravni pa je zgodnja podjetniška aktivnost narasla.

- V vseh fazah celotnega podjetniškega procesa je bil v letu 2020 delež tistih, ki so bili vključeni v podjetniško aktivnost, manjši v primerjavi z letom prej, kar bi lahko pripisali spremenjenim pogojem v poslovnem okolju v zadnjem letu.

- Kot največkrat naveden motiv za podjetništvo so podjetniki v Sloveniji navedli preživetje, saj so primerne zaposlitve redke (72,2\%). Temu sledijo želje podjetnikov po ustvarjanju sprememb v svetu $(44,6 \%)$ in ustvarjanje premoženja $(39,7 \%)$, šele na zadnjem mestu je nadaljevanje družinskega posla ali tradicije (21,6 \%).

- V Sloveniji je v času krize zaradi covida-19 $32 \%$ zgodnjih podjetnikov zaznalo nove poslovne priložnosti, kar je toliko kot v povprečju v evropskih državah. Najmanj slovenskih nastajajočih podjetnikov med evropskimi državami pa je v tem času tudi zaznalo težave pri razvoju podjetja in prehodu med nove podjetnike.

- Delež podjetnikov, ki so izstopili iz podjetniškega procesa, je v Sloveniji majhen v primerjavi z deležem v evropskih državah. Med razlogi prevladujejo prodaja, izkoriščanje druge priložnosti, upokojitev ali drugi osebni razlogi (65,2 \%), sledijo finančni razlogi (13,4\%), davčne in vladne politike ali birokracija (9,3\%). Krizo zaradi covida-19 je kot razlog za izstop navedlo 12,1 \% podjetnikov, kar je bistveno manj kot v evropskih državah (20,1 \%). 


\subsection{Faze in učinkovitost podjetniškega procesa}

Novoustanovljena podjetja imajo ključno vlogo v gospodarstvih, toda kriza zaradi covida-19 zmanjšuje njihovo ustanavljanje, ogroža njihovo preživetje in omejuje njihovo rast. V zadnjih mesecih se ustanavlja vse manj novih podjetij, zmanjševanje števila novih podjetij pa ima pomembne posledice za gospodarske rezultate, zlasti zaposlovanje (OECD, 2020). Oblikovalci politike se spoprijemajo s kratkoročnimi izzivi, kako podpirati kratkoročno likvidnost podjetij in razpoložljivost finančnih sredstev, hkrati pa tudi pomembno spodbujati sposobnost startup podjetij, da izkoristijo nove poslovne priložnosti. Politike, ki zmanjšujejo podjetniške ovire ter spodbujajo novoustanovljena podjetja in podjetniški potencial, bi lahko pripomogle k hitrejšemu okrevanju in dolgoročnemu ohranjanju stopnje zaposlenosti.

Podjetniški proces je vznemirljiv, a tvegan tudi v okolju, ki je stabilno in predvidljivo. Zadnje leto se v poslovnem okolju pojavljajo izrazito hitre in nepredvidljive spremembe in veliko ljudi se na takšne situacije odziva z izogibanjem tveganju. Kriza zaradi covida-19 je veliki večini podjetnikov porušila načrte, spremenila prednostne naloge in obstoječe mreže in načine dela, vendar zagonska podjetja še naprej igrajo ključno vlogo v gospodarstvih. Nekatera inovativna mlada podjetja so se hitro in prilagodljivo odzvala na pandemijo in so ključnega pomena pri prehodu na digitalne oblike dela, izobraževanje in druge storitve, hkrati pa so ponudila inovacije pri obstoječih izdelkih in storitvah. OECD v aktualni analizi krize zaradi covida-19 (OECD, 2020) analizira izzive, s katerimi se soočajo novoustanovljena podjetja, in priložnosti, ki se lahko pojavijo v tem času. Ugotavljajo, da kriza zmanjšuje ustanavljanje novih podjetij, izziva njihovo preživetje in omejuje njihovo rast. Manjkajoča generacija novih podjetij bo imela pomembne posledice za gospodarske rezultate, zlasti zaposlovanje, ki jih je mogoče omiliti s podporo obstoječim novoustanovljenim podjetjem in pri ustanavljanju novih podjetij. Oblikovalci politike se morajo spoprijeti s kratkoročnimi izzivi, hkrati pa morajo tudi spodbujati sposobnost zagonskih podjetij, da izkoristijo nove poslovne priložnosti, zmanjšati ovire za podjetništvo, zagotoviti prave spodbude in povečati podjetniški potencial.

Podjetniški okvir smo v prejšnjem poglavju analizirali z vidika odnosa družbe do pojava podjetništva in podjetniške zmogljivosti posameznikov. V tem poglavju se osredotočamo na podjetniški proces in posameznike, ki v njem zaznavajo in izkoriščajo poslovne priložnosti. Uporabljamo model, prikazan na sliki 4.1, razdeljen v več karakterističnih faz (Bosma et al., 2012). V tem procesu zaporedne faze predstavljajo najprej potencialni podjetniki (ang. potential entrepreneurs), ki jim sledijo nastajajoči podjetniki (ang. nascent entrepreneurs) in nato novi podjetniki (ang. new entrepreneurs). Nastajajoči in novi podjetniki skupaj tvorijo celotno zgodnjo podjetniško aktivnost, eno izmed osnovnih mer raziskave GEM. Naslednjo fazo sestavljajo ustaljeni podjetniki (ang. established entrepreneurs), zadnjo fazo pa predstavlja izstop podjetnika iz posla (ang. exiting the business).

Posameznikov, ki prepoznavajo poslovne priložnosti, sprejemajo tveganje in menijo, da imajo dovolj znanja in podjetniških sposobnosti, da uresničijo podjetniški podjem (potencialnih podjetnikov), je bilo v Sloveniji v letu 2020 13,3 \% (16,6 \% v 2019). Ti posamezniki dejansko še niso začeli z aktivnostmi ustanavljanja podjema. Sem spadajo šele nastajajoči podjetniki. Teh je bilo v letu 2020 3,1 \% (4,4 \% v 2019), vključeni pa so v nastajanje podjetja, ki je mlajše kot tri mesece. Novih podjetnikov v naslednji fazi je bilo 3,0 \% (3,6 \% v 2019), to pa so podjetniki, 
Slika 4.1: Izbrani kazalniki podjetniškega procesa v Sloveniji

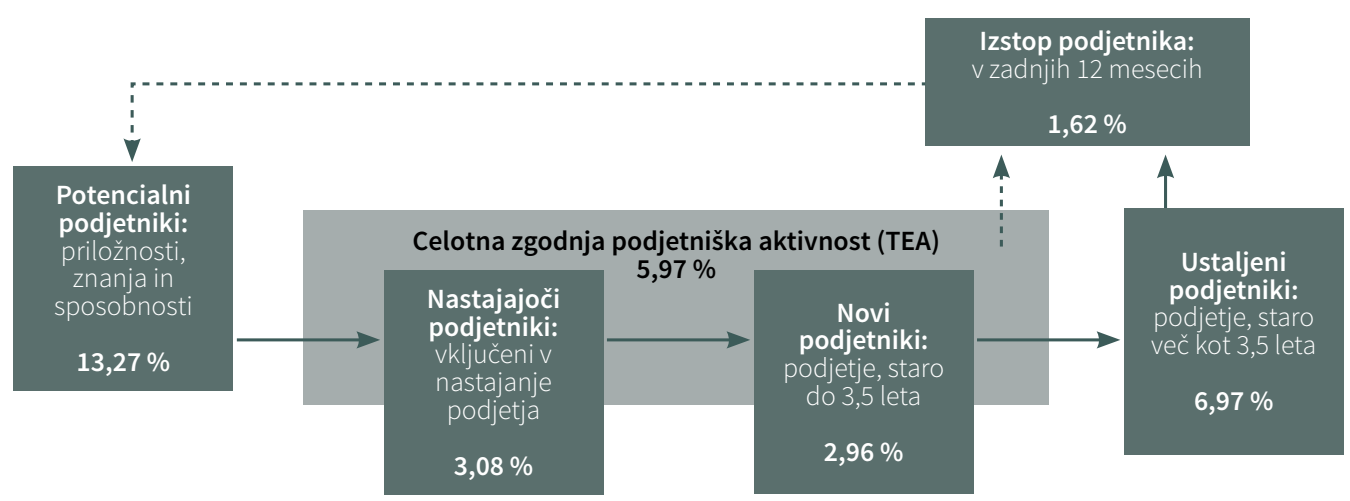

GEM Slovenija 2020, APS

ki imajo podjetje in izplačujejo plače več kot tri mesece, vendar ne več kot tri leta in pol. Celotno zgodnjo podjetniško aktivnost, ki jo merimo z indeksom TEA (ang. total early-stage entrepreneurial acitivity), skupaj sestavljajo nastajajoči in novi podjetniki, ki jih je bilo v letu 2020 6,0\% (7,8\% v 2019). Nekaj podjetnikov je takih, ki hkrati razvijajo tako nastajajoče kot nove podjeme, zato se indeks TEA nekoliko razlikuje od seštevka nastajajočih in novih podjetnikov. Ustaljeni podjetniki v naslednji fazi so posamezniki, ki imajo podjetje, staro več kot tri leta in pol. V letu 2020 jih je bilo v Sloveniji 7,0 \% (8,5\% v 2019). Njihov posel je bolj stabilen, z razvitimi proizvodi in razmeroma stalnimi odjemalci. $V$ podjetniškem procesu $v$ zadnjo fazo sodijo podjetniki, ki so $v$ zadnjih 12 mesecih izstopili iz podjetništva. $\vee$ letu 2020 jih je bilo v Sloveniji 1,6 \% (1,9\% v 2019).

Analiza podatkov v celotnem podjetniškem procesu tako kaže, da je podjetniška aktivnost v primerjavi s preteklim letom upadla. Če upoštevamo, da se podjetniški proces zmeraj odvija $\checkmark$ danem okolju in da je odvisen od razmer v njem, potem je upad aktivnosti pričakovan. Kriza zaradi covida-19 je namreč močno spremenila trenutne razmere $\vee$ gospodarstvu, ki posameznikov zagotovo ne spodbujajo in motivirajo za podjetniško pot. Ker že od pomladi 2020 v Sloveniji traja epidemija, ki je povzročila omejevanje dejavnosti v velikem delu gospodarstva na eni strani in zmanjševanje potrošnje na drugi, je razumljivo, da se to odraža tudi v zmanjšanem zaznavanju poslovnih priložnosti in odločanju za začetek podjetništva. Ob tem se ukrepi, ki so namenjeni zmanjševanju negativnih učinkov krize na gospodarstvo, osredotočajo predvsem na ustaljena podjetja. Za nove podjetnike pa ostajajo na voljo podobni ukrepi za spodbujanje startup podjetij kot že pred covidom-19. Osredotočenost na pomoč obstoječim podjetjem je najverjetneje tudi razlog, da je v zadnjem letu s podjetništvom prenehalo manj podjetnikov.

Proučevanje podjetniške aktivnosti kot procesa pomeni, da je dinamika med posameznimi fazami zmeraj prisotna, kar lahko prikažemo s tako imenovanim podjetniškim vodom (ang. entrepreneurial pipeline), ki je za leti 2019 in 2020 v Sloveniji prikazan na sliki 4.2. 
Slika 4.2: Puščanje podjetniškega voda v Sloveniji

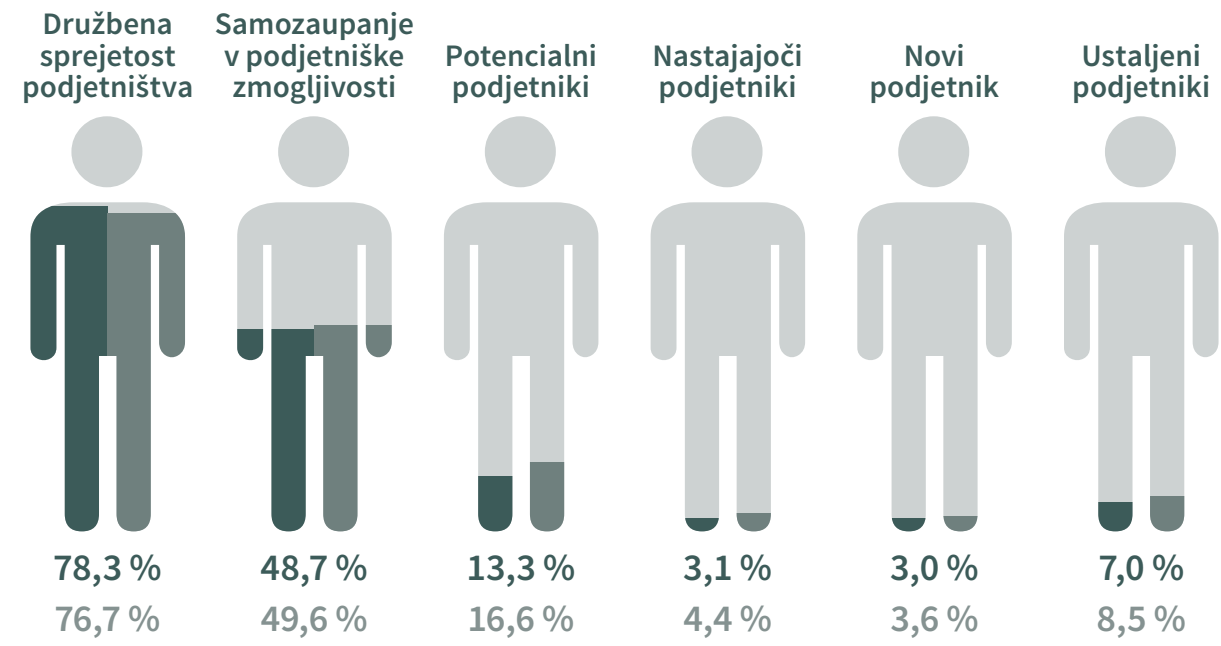

\section{9}

$76,7 \%$

GEM Slovenija 2020, APS

Tako lahko nazorneje in v širšem kontekstu kot z opisom podjetniškega procesa prikažemo celoten spekter podjetniških aktivnosti, v katere so zajeti posamezniki, ki so vključeni v posamezne faze podjetniškega procesa. Posamezniki v predhodni fazi so namreč vir tistih, ki potencialno preidejo $\checkmark$ naslednjo fazo $v$ procesu podjetniškega voda:

- Družbena sprejetost podjetništva vključuje najširši kontekst in prikazuje delež posameznikov, ki izkazujejo namere za podjetništvo, zaznavajo poslovne priložnosti in odločitve o podjetniški karieri. Mera družbene sprejetosti podjetništva predstavlja aritmetično sredino treh elementov, in sicer 1) posameznikov, ki dojemajo podjetništvo kot družbeno zaželeno poklicno izbiro, 2) posameznikov, ki menijo, da so uspešni podjetniki v družbi spoštovani in imajo visok družbeni status, in 3) posameznikov, ki zaznavajo, da je v medijih mogoče pogosto zaslediti zgodbe o uspešnih podjetnikih. Pozitiven odnos do podjetništva je v letu 2020 izražalo 78,3 \% prebivalcev v Sloveniji, kar je nekoliko več kot leto poprej (76,7 \%).

- Samozaupanje v podjetniške zmogljivosti predstavlja osebna prepričanja posameznikov o zmožnostih za podjetništvo, pomeni pa delež posameznikov, ki 1) menijo, da imajo potrebne sposobnosti, znanje in izkušnje za podjetništvo, 2) zaznavajo poslovne priložnosti v okolju in 3) jih strah pred neuspehom ne bi odvrnil od podjetniške poti. Ljudje tudi vse bolj izražajo prepričanja v podjetniške sposobnosti in takih je bilo v letu 2020 48,7 \%.

Vse preostale faze v podjetniškem procesu z vidika podjetniškega voda (potencialne, nastajajoče, nove in ustaljene podjetnike) obravnavamo v nadaljevanju poglavja. Vendar pa podjetniški vod jasno prikazuje, da v Sloveniji izgubljamo podjetniški potencial pri prehodih iz začetnih faz v naslednje. V letu 2020 je ta upad še izrazitejši kot leto prej. Čeprav podatki kažejo, da je v letu 2020 več posameznikov v družbi sprejemalo podjetništvo kot zaželeno v primerjavi z letom 2019, se jih je dejansko v naslednjih fazah za podjetniško pot odločilo manj.

Proučevanje podjetniškega procesa v Sloveniji z vidika mednarodnih primerjav omogoča tabela 4.1, v kateri je prikazana podjetniška aktivnost v posameznih fazah in po posameznih skupinah držav. Šele postavitev podjetniškega procesa v mednarodni kontekst poda dejansko primerjavo na globalni ravni. 
Tabela 4.1: Pregled podjetniške aktivnosti med odraslim prebivalstvom po posameznih fazah in po skupinah držav, GEM Slovenija 2020, APS

\begin{tabular}{|c|c|c|c|c|}
\hline Faze podjetniške aktivnosti & Slovenija & GEM & $\begin{array}{r}\text { Visokodohodkovne } \\
\text { države }\end{array}$ & $\begin{array}{r}\text { Evropske } \\
\text { države }\end{array}$ \\
\hline Nastajajoči podjetniki & $3,08 \%$ & $8,55 \%$ & $8,08 \%$ & $5,03 \%$ \\
\hline Novi podjetniki & $2,96 \%$ & $6,24 \%$ & $4,94 \%$ & $3,24 \%$ \\
\hline Celotna zgodnja podjetniška aktivnost & $5,97 \%$ & $14,47 \%$ & $12,75 \%$ & $8,14 \%$ \\
\hline Ustaljeni podjetniki & $6,97 \%$ & $7,54 \%$ & $6,80 \%$ & $6,90 \%$ \\
\hline Prenehanje poslovanja & $1,62 \%$ & $6,60 \%$ & $5,22 \%$ & $2,85 \%$ \\
\hline
\end{tabular}

Z vidika mednarodne primerjave ugotavljamo, da Slovenija za primerjanimi skupinami držav (visokodohodkovne države, evropske države in vse države GEM) zaostaja v celotni podjetniški aktivnosti tako med nastajajočimi kot med novimi podjetniki. Te razlike so največje v primerjavi z vsemi državami GEM, zmanjšujejo pa se pri primerjavi z evropskimi oziroma visokodohodkovnimi državami, vendar so zaostanki še zmeraj veliki. Primerljive rezultate z drugimi skupinami držav izkazujemo pri ustaljenih podjetnikih, precej boljše rezultate pa pri primerjavi prenehanja poslovanja, iz česar lahko sklepamo, da so podporne politike za podjetništvo potrebne predvsem v začetnih fazah procesa.

\subsection{Zgodnja podjetniška aktivnost}

Celotno zgodnjo podjetniško aktivnost v okviru raziskave GEM proučujemo v najširšem smislu. Sestavljajo jo posamezniki, ki so začeli ustanavljati podjetje, vendar podjetje plač ne izplačuje več kot tri leta in pol. Celotna zgodnja podjetniška aktivnost predstavlja eno izmed osrednjih mer raziskave GEM, merimo jo z indeksom TEA, ki ga sestavljajo nastajajoči in novi podjetniki. Začetne aktivnosti nastajajočih podjetnikov so velikokrat odvisne od okolja, v katerem tak posameznik deluje, od njegove motivacije in podpore ter tudi od širših okvirnih pogojev za podjetništvo v neki državi (na primer Lombardi et al., 2020; Caputo et al., 2020). Nastajajoče podjetnike opredeljujemo kot posameznike, ki so začeli ustanavljati podjetje, vendar to podjetje plač ne izplačuje več kot tri mesece. V Sloveniji jih je bilo v preteklem letu 3,08\%, kar je več kot odstotno točko manj kot leta 2019 (4,37\%). Podobno velja tudi za nove podjetnike, ki predstavljajo naslednjo fazo, gre pa za posameznike, ki izplačujejo plače več kot tri mesece in manj kot tri leta in pol. V Sloveniji jih je bilo v preteklem letu 2,96 \%, leto poprej pa 3,6\%. Ponovno nam boljše informacije ponuja primerjava z drugimi državami. Medtem ko v evropskih državah zaznavamo upad tako nastajajočih kot novih podjetnikov v letu 2020 glede na leto 2019, pa se na globalni ravni kaže povečanje deleža obojih. Spremembe so lahko posledica spremenjenih pogojev za podjetništvo v zadnjem letu zaradi covida-19. $\vee$ evropskih državah namreč $v$ teh fazah zaznavamo upad podjetniške aktivnosti, $v$ manj razvitih in revnejših državah pa zaznavamo porast. Pojav je večplasten in ima več razlogov. Na eni strani je v manj razvitih državah več podjetništva iz nuje, manj socialne varnosti, ko ljudje nimajo drugih možnosti za zaposlitev. V razvitejših državah je možnosti za zaposlitev več, hkrati pa so hitre spremembe v okolju v zadnjem letu posameznike v teh državah odvračale od podjetništva zaradi tveganja. Ti rezultati se odražajo tudi v rezultatih celotne podjetniške aktivnosti, ki je za evropske države v letu 2020 prikazana na sliki 4.3. V povprečju je indeks TEA v evropskih državah znašal 8,1 \%. Med njimi dosegajo najvišje stopnje zgodnje podjetniške aktivnosti Latvija (15,6 \%), Slovaška (13,9 \%) in Hrvaška (12,7 \%), najnižje pa Italija (1,9 \%), Poljska (3,1 \%) in Nemčija (4,8 \%). 
Razlike med posameznimi evropskimi državami so zelo velike, glede na leto 2019 so se absolutne razlike med državama z najvišjo in najnižjo stopnjo celo povečale (Italija 2,8 \% in Latvija 15,4% v letu 2019).

V Sloveniji je sicer glede na leto 2019 indeks TEA upadel s 7,8 \% na 6,0 \%, vendar smo v evropskem merilu šele na 14. mestu med 18 državami. Torej šele relativna primerjava pokaže, da smo se glede na indeks TEA uvrstili v zadnjo tretjino evropskih držav.

Slika 4.3: Celotna zgodnja podjetniška aktivnost (v evropskih državah GEM)

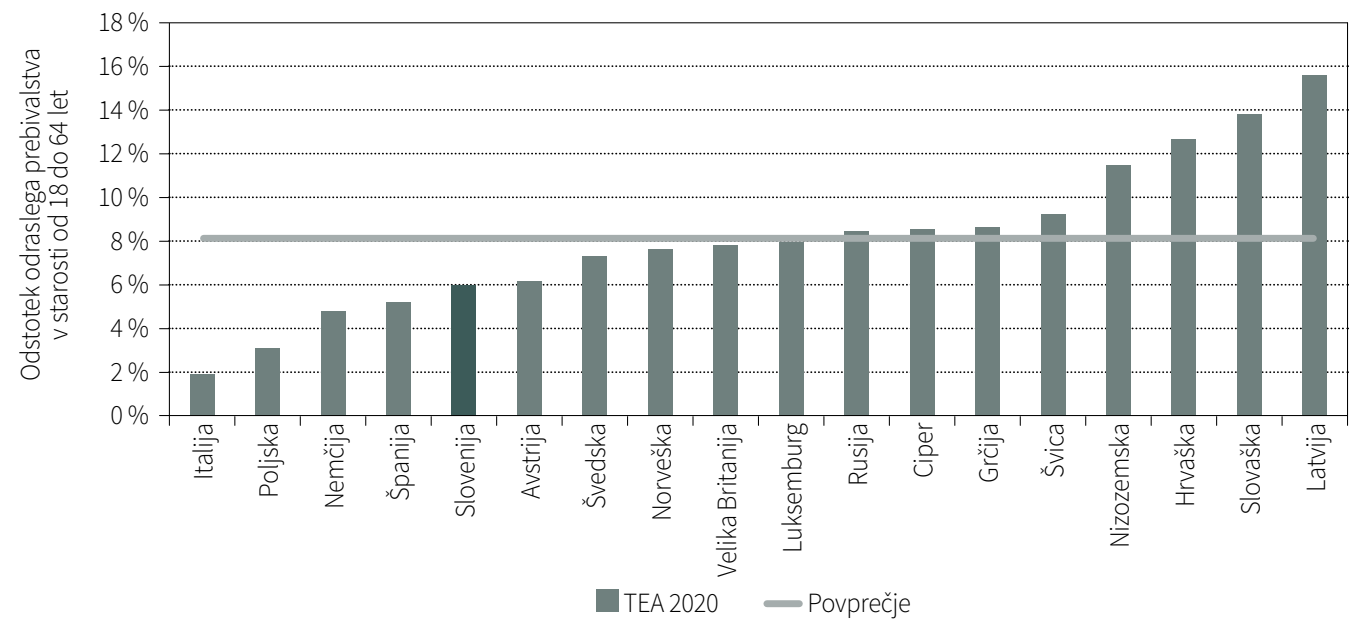

GEM Slovenija 2020, APS

Spremembe indeksa TEA v zadnjih 10 letih v Sloveniji kažejo na izrazita nihanja (slika 4.4). Če smo v letu 2011 dosegli najnižji TEA, le 3,7 \%, pa smo po ponovnem porastu zgodnje podjetniške aktivnosti leta 2019 (7,8\%) v letu 2020 zaznali upad (6,0\%). To je najverjetneje posledica krize zaradi covida-19, ki se je začela v začetku leta 2020. Kljub temu, da podporno okolje za podjetništvo (med njimi so ključni Ministrstvo za gospodarski razvoj in tehnologijo, SPIRIT Slovenija in Slovenski podjetniški sklad) z ukrepi spodbujanja mladih, zagonskih in inovativnih podjetij s kombinacijo finančnih in nefinančnih podpor (SPS, 2021) podpira del inovativnih podjetij, pa velik del podjetij, ki ne spadajo $v$ to skupino, ni deležen posebnih spodbud. Ta podjetja so bila izpostavljena spremenjenim razmeram na trgu, ki v zadnjem letu za ustanavljanje novih podjetij niso bile preveč spodbudne. 
Slika 4.4: Celotna zgodnja podjetniška aktivnost v Sloveniji v letih od 2010 do 2020

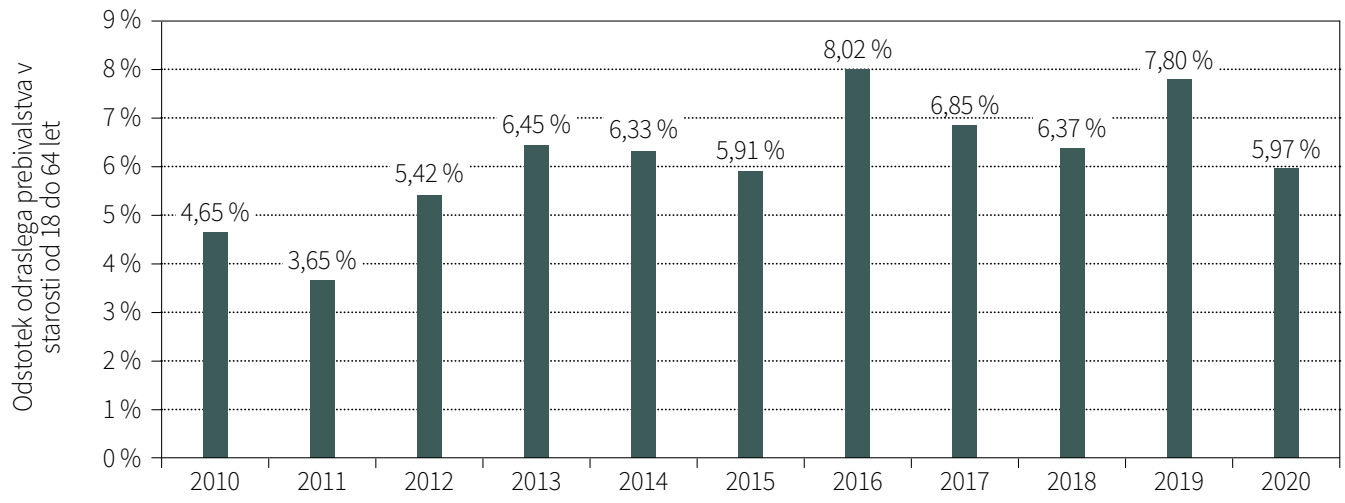

GEM Slovenija 2020, APS

Primerjava celotne zgodnje podjetniške aktivnosti povprečno $v$ državah GEM, v evropskih državah in v Sloveniji (slika 4.5) pokaže, da se v razvitejših državah manj posameznikov odloči za podjetništvo. $\vee$ teh državah je namreč na voljo dovolj drugih oblik pridobivanja dohodka, kot je na primer zaposlovanje $\vee$ večjih podjetjih, ki nadomešča podjetniško aktivnost. $\vee$ manj razvitih državah ali državah z nižjimi dohodki je na voljo manj zaposlitev, zato so se posamezniki primorani podati v podjetništvo, četudi to ni njihova prva motivacija ali izbira. V vseh državah GEM je 2,4-krat več zgodnje podjetniške aktivnosti kot v Sloveniji, v evropskih državah pa 1,3-krat več.

Slika 4.5: Indeks TEA v izbranih skupinah držav

\section{Zgodnja podjetniška aktivnost}

Slovenija

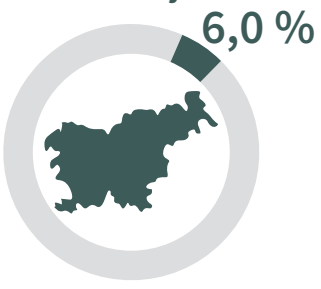

Evropa

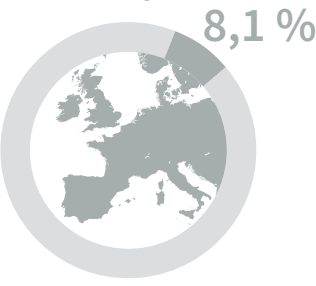

Države GEM

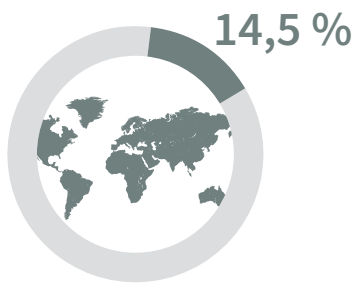

GEM Slovenija 2020, APS

V podjetniškem procesu pri prehodu v naslednje faze delež vključenosti v podjetniško aktivnost praviloma upada. Ta upad je še posebej smotrno proučevati v začetnih fazah procesa. $V$ tabeli 4.2 je prikazano razmerje med nastajajočimi in novimi podjetniki v Sloveniji; to razmerje merimo z indeksom smrtnosti. Takšno imenovanje si je prislužil, ker predstavlja razmerje med deležem posameznikov, ki so začeli s podjetniškimi aktivnostmi, vendar so jih že takoj na začetku, v fazi nastajanja, tudi opustili, in novimi podjetniki. Podjetniki, ki so povsem na začetku razvoja svojih poslovnih idej in jih želijo spremeniti $v$ donosen posel, potrebujejo posebno podporo okolja, saj so v teh fazah najranljivejši in jih zato idejo veliko tudi opusti. Običajno je delež nastajajočih podjetnikov večji od deleža novih, saj del podjetnikov ne realizira svojih podjemov in jih posledično ne pripelje v naslednjo fazo. Prav to nakazuje razmerje med nastajajočimi in novimi podjetniki, ki je 
za Slovenijo v letu 2020 zelo dobro, saj znaša 1,04, kar pomeni, da od 104 nastajajočih podjetnikov razvoj podjema opustijo samo 4 podjetniki (leta 2016 je bilo razmerje celo 1,64).

Tabela 4.2: Razmerje med nastajajočimi in novimi podjetniki ter indeks smrtnosti v Sloveniji v letih od 2011 do 2020, GEM Slovenija 2020, APS

\begin{tabular}{|l|r|r|r|}
\hline Leto & Nastajajoči podjetniki & Novi podjetniki & Indeks smrtnosti \\
\hline 2011 & 1,91 & 1,75 & 1,09 \\
\hline 2012 & 2,95 & 2,53 & 1,17 \\
\hline 2013 & 3,58 & 2,87 & 1,25 \\
\hline 2014 & 3,78 & 2,66 & 1,42 \\
\hline 2015 & 3,22 & 2,79 & 1,15 \\
\hline 2016 & 5,06 & 3,08 & 1,64 \\
\hline 2017 & 4,02 & 2,96 & 1,36 \\
\hline 2018 & 2,84 & 3,64 & 0,78 \\
\hline 2019 & 4,37 & 3,55 & 1,23 \\
\hline 2020 & 3,08 & 2,96 & 1,04 \\
\hline
\end{tabular}

Ta majhen upad pri prehodu iz faze nastajajočih v fazo novih podjetnikov je mogoče dopolniti tudi z ugotovitvami, da so se nastajajoči podjetniki v Sloveniji v najmanjšem deležu med evropskimi državami strinjali, da je kriza zaradi covida-19 vplivala na zamude pri nadaljnjem razvijanju podjetja in prehodu med nove podjetnike. Čeprav se je kar $45 \%$ vprašanih s tem povsem ali delno strinjalo, pa je povprečje v Evropi bistveno višje in znaša 61 \% (slika 4.6). Sklepamo lahko, da so k velikemu prehodu prispevali tudi ukrepi podpornega okolja, namenjeni zagonskim podjetjem (SPS, 2021), ki so bili na voljo tako v letu 2020 kot tudi v letu 2021.

Slika 4.6: Nastajajoči podjetniki s težavami pri prehodu med nove podjetnike zaradi krize zaradi covida-19 (v evropskih državah GEM)

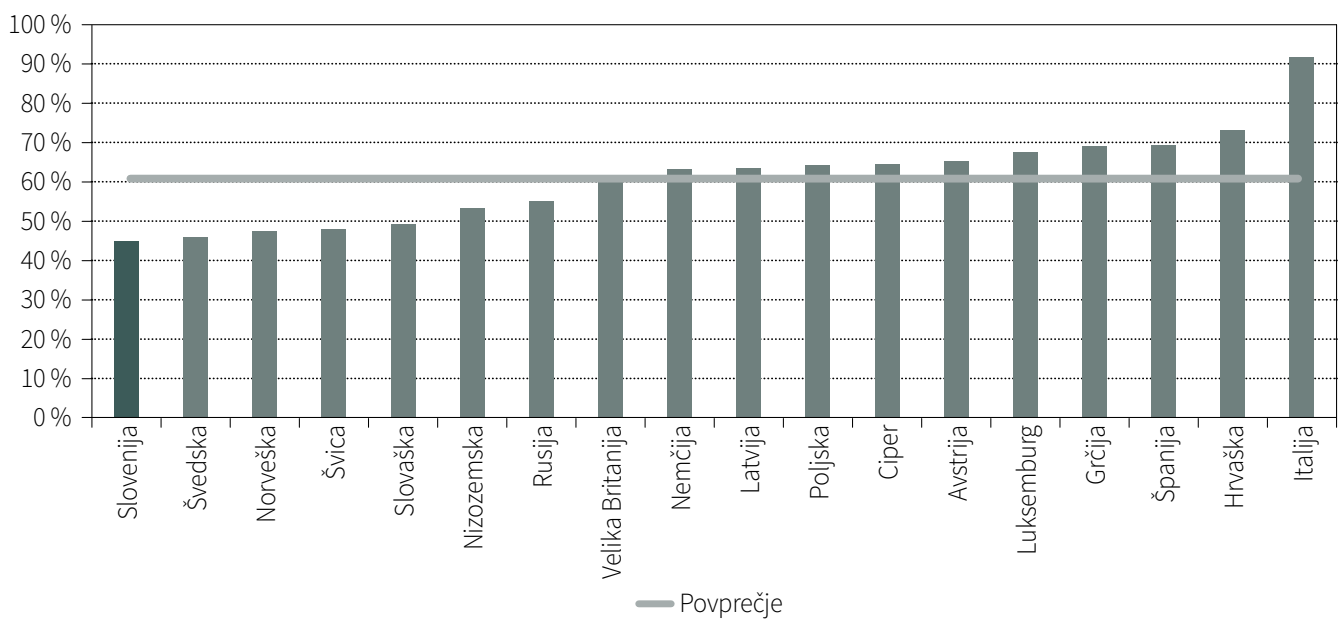




\subsection{Motivacija za podjetništvo}

Na odločitve v življenju posameznika vplivajo njegove osebnostne lastnosti in prioritete, ki vplivajo tudi na odločanje v zgodnjih fazah podjetniškega procesa (Santos et al., 2021). Osebni motivi podjetnikov in vrsta poslovne priložnosti sta tista ključna dejavnika, ki vplivata tako na odločanje za podjetništvo kot na sam proces. Raznolikost motivov, ki jih proučujemo v okviru raziskave GEM, smo združili v štiri skupine, in sicer:

- želja po ustvarjanju spremembe v svetu,

- želja po ustvarjanju premoženja oziroma večjega dohodka,

- želja po nadaljevanju družinskega podjetja oziroma tradicije,

- potreba po preživetju, ker so službe redke.

$\checkmark$ tabeli 4.3 so prikazani motivi zgodnjih podjetnikov $v$ evropskih državah GEM, ki so na petstopenjski lestvici izražali strinjanje s posameznimi razlogi za podjetništvo, pri čemer je lahko vsak izbral več motivov. Prvi motiv, želja po ustvarjanju spremembe v svetu, kaže na altruistične motive posameznikov, ki se za podjetništvo odločijo predvsem z željo po prispevanju k doseganju trajnostnih ciljev, kot so družbene ali okoljske spremembe. V evropskih državah je več kot polovica zgodnjih podjetnikov ta motiv navedla v Veliki Britaniji (57,6 \%) in Luksemburgu (51,1 \%). Najmanj zgodnjih podjetnikov pa je željo po ustvarjanju sprememb v svetu navedlo na Poljskem (22 \%), v Rusiji (24,2 \%) in Italiji (26,6\%). V Sloveniji je bilo takih podjetnikov 44,6\%, kar je malo manj kot leto prej $(48,2 \%)$.

Drugi motiv, ustvarjanje premoženja oziroma povečevanje dohodka, je v dveh evropskih državah, v Italiji (95,3\%) in na Cipru (85,2\%), izredno pogost razlog za podjetništvo. Na tretjem mestu je Rusija, kjer pa je ta motiv navedlo le 68,7 \% zgodnjih podjetnikov. Najmanj posameznikov je ustvarjanje premoženja in prihodka navedlo na Norveškem (30,1\%), v Švici (32,5\%), Avstriji $(33,4 \%)$ in Španiji $(34,9 \%)$. V Sloveniji je zgodnjih podjetnikov s tem ciljem 39,7 \%, kar je precej manj kot leto prej (47,1\%).

Tretji motiv, nadaljevanje družinskega podjetja oziroma tradicije, se nanaša predvsem na podjetnike, ki so prevzemniki družinskih podjetij. Teh je v evropskih državah najmanj med vsemi štirimi proučevanimi skupinami motivov. To tradicijo jih sicer daleč največ nadaljuje $\vee$ Nemčiji (62\%), sledi ji Grčija (35,7\%). Manj kot petina zgodnjih podjetnikov v Evropi nadaljuje družinsko tradicijo na Norveškem (11,8\%), v Rusiji (16,5\%), Luksemburgu (16,6\%) in Španiji (17,4\%). V Sloveniji ta motiv navaja 21,6 \% zgodnjih podjetnikov.

Četrti motiv odločanja za podjetništvo, preživetje, ker so službe redke, je motiv, ki se najbolj med vsemi nanaša na podjetništvo iz nuje. Tudi pri tem motivu so razlike med posameznimi državami velike, čeprav je pogostejši v manj razvitih državah, kjer ni ustreznih zaposlitev in so se ljudje primorani podati v podjetništvo. Največkrat so ta motiv izrazili zgodnji podjetniki v Italiji (82,2 \%), na Cipru (77,4 \%) in na Slovaškem (73,8 \%). Najmanj jih je ta motiv navedlo na Norveškem $(23,1 \%)$ in Švedskem (28,9 \%). V Sloveniji je ta motiv za podjetništvo precej pogost, saj ga je navedlo 72,2% zgodnjih podjetnikov, kar je precej več kot leto poprej (60,1\%). Vendar pa tega motiva v razvitih državah ne moremo enačiti s splošnim pomanjkanjem služb ali odsotnostjo velikih podjetij, ki zagotavljajo delovna mesta, ampak predvsem s strukturnim neskladjem med povpraševanjem po delovnih mestih in njihovo ponudbo. 
Tabela 4.3: Motivi nastajajočih in novih podjetnikov (vevropskih državah GEM), GEM Slovenija 2020, APS

\begin{tabular}{|c|c|c|c|c|}
\hline $\begin{array}{l}\text { Evropske } \\
\text { države }\end{array}$ & $\begin{array}{r}\text { TEA - ustvariti } \\
\text { spremembo v } \\
\text { svetu* }\end{array}$ & $\begin{array}{r}\text { TEA - ustvariti } \\
\text { premoženje oziroma } \\
\text { večji dohodek }\end{array}$ & $\begin{array}{r}\text { TEA - nadaljevati } \\
\text { družinsko podjetje/ } \\
\text { tradicijo* }\end{array}$ & $\begin{array}{l}\text { TEA - preživeti, saj } \\
\text { so službe redke }\end{array}$ \\
\hline Avstrija & 38,97 & 33,37 & 21,07 & 49,27 \\
\hline Ciper & 37,48 & 85,21 & 21,31 & 77,43 \\
\hline Grčija & 26,86 & 45,80 & 35,74 & 68,97 \\
\hline Hrvaška & 38,95 & 46,95 & 28,70 & 69,44 \\
\hline Italija & 26,63 & 95,33 & 26,46 & 82,21 \\
\hline Latvija & 39,77 & 41,81 & 27,53 & 73,58 \\
\hline Luksemburg & 51,07 & 40,29 & 16,63 & 44,29 \\
\hline Nemčija & 39,82 & 52,21 & 62,02 & 45,13 \\
\hline Nizozemska & 46,59 & 40,91 & 24,56 & 47,80 \\
\hline Norveška & 36,66 & 30,13 & 11,83 & 23,14 \\
\hline Poljska & 21,97 & 52,82 & 20,37 & 62,04 \\
\hline Rusija & 24,21 & 68,65 & 16,53 & 71,38 \\
\hline Slovaška & 33,61 & 38,33 & 32,36 & 73,78 \\
\hline Slovenija & 44,60 & 39,71 & 21,60 & 72,19 \\
\hline Španija & 32,30 & 34,86 & 17,36 & 72,27 \\
\hline Švedska & 41,50 & 42,75 & 24,20 & 28,87 \\
\hline Švica & 42,52 & 32,48 & 20,13 & 52,02 \\
\hline Velika Britanija & 57,61 & 59,40 & 20,65 & 54,41 \\
\hline
\end{tabular}

Opomba: *Delež tistih, ki se strinjajo ali močno strinjajo s trditvijo v celotni zgodnji podjetniški aktivnosti (\% TEA).

Pregled posameznih motivov v izbranih skupinah držav je prikazan v tabeli 4.4. Želja po ustvarjanju spremembe v svetu postavlja Slovenijo s 44,6 \% zgodnjih podjetnikov, ki sledijo temu motivu, na 4. mesto med 18 evropskimi državami, na 13. mesto med 31 visokodohodkovnimi državami in na 19. mesto med 43 državami v svetu. Drugi motiv, ustvariti si premoženje ali povečati prihodke, čemur v Sloveniji sledi 39,7\% zgodnjih podjetnikov, postavlja Slovenijo na 13. mesto med evropskimi državami, na 26. mesto med visokodohodkovnimi državami in na 38. mesto v svetovnem merilu. Tretji motiv, nadaljevanje družinske tradicije, v Sloveniji izpostavlja najmanj zgodnjih podjetnikov, le 21,6\%. To Slovenijo postavlja na 9. mesto v Evropi, na 21. mesto med visokodohodkovnimi državami in na 38. mesto v svetu. Zadnji motiv za podjetništvo, preživetje, ker so službe redke, v Sloveniji izpostavlja 72,2 \% zgodnjih podjetnikov, kar nas postavlja na 6. mesto v Evropi, na 13. mesto med visokodohodkovnimi državami in na 20. mesto v svetovnem merilu.

Ugotavljamo, da so pri pogostosti posameznih motivov med državami ogromne razlike, kar je razvidno tudi iz tabele 4.4. Medtem ko v Indiji želi s podjetništvom ustvariti spremembe v svetu kar 80,7 \% zgodnjih podjetnikov, je v Kazahstanu takih le 0,4\%. V Indiji tudi skoraj $75 \%$ zgodnjih podjetnikov želi nadaljevati družinsko tradicijo, v Južni Koreji pa je takih le $5 \%$. Velike razlike se izkazujejo tudi pri želji po ustvarjanju premoženja. Največ takih podjetnikov je v Italiji, kar 95,3%, na Norveškem pa le 30,1\%. 
Tabela 4.4: Ključne značilnosti motivov za podjetništvo v celotni zgodnji podjetniški aktivnosti, GEM Slovenija 2020, APS

\begin{tabular}{|c|c|c|c|c|}
\hline & $\begin{array}{r}\text { TEA - ustvariti } \\
\text { spremembo v }^{v} \\
\text { svetu }^{*}\end{array}$ & $\begin{array}{r}\text { TEA - ustvariti } \\
\text { premoženje oziroma } \\
\text { večji dohodek }\end{array}$ & $\begin{array}{r}\text { TEA - nadaljevati } \\
\text { družinsko } \\
\text { podjetje/tradicijo* }\end{array}$ & $\begin{array}{r}\text { TEA - preživeti, } \\
\text { saj so službe } \\
\text { redke }^{\star}\end{array}$ \\
\hline Slovenija & $44,60 \%$ & $39,71 \%$ & $21,60 \%$ & $72,19 \%$ \\
\hline Najvišja vrednost & $\begin{array}{r}\text { Indija } \\
80,70 \%\end{array}$ & $\begin{array}{r}\text { Italija } \\
95,33 \%\end{array}$ & $\begin{array}{r}\text { Indija } \\
74,69 \%\end{array}$ & $\begin{array}{r}\text { Gvatemala } \\
91,05 \%\end{array}$ \\
\hline Najnižja vrednost & $\begin{array}{r}\text { Kazahstan } \\
0,37 \%\end{array}$ & $\begin{array}{r}\text { Norveška } \\
30,13 \%\end{array}$ & $\begin{array}{r}\text { Južna Koreja } \\
5,01 \%\end{array}$ & $\begin{array}{r}\text { Norveška } \\
23,14 \%\end{array}$ \\
\hline $\begin{array}{l}\text { Rang Slovenije med } \\
\text { vsemi državami GEM }\end{array}$ & $19 / 43$ & $38 / 43$ & $29 / 43$ & $20 / 43$ \\
\hline $\begin{array}{l}\text { Rang Slovenije med } \\
\text { visokodohodkovnimi } \\
\text { državami GEM }\end{array}$ & $13 / 31$ & $26 / 31$ & $21 / 31$ & $13 / 31$ \\
\hline $\begin{array}{l}\text { Rang Slovenije med } \\
\text { evropskimi državami } \\
\text { GEM }\end{array}$ & $4 / 18$ & $13 / 18$ & $9 / 18$ & $6 / 18$ \\
\hline
\end{tabular}

Opomba: *Deležt tistih, ki se strinjajo ali močno strinjajo strditvijo, v celotni zgodnji podjetniški aktivnosti (\% TEA).

Kriza zaradi covida-19 je povzročila velike spremembe $\vee$ podjetništvu, vendar niso zmeraj negativne. Čeprav je za nekatera podjetja pomenila težave v poslovanju, pa je za marsikaterega podjetnika pomenila tudi pojavljanje novih poslovnih priložnosti. Na sliki 4.7 je prikazan delež zgodnjih podjetnikov, ki so v času krize zaradi covida-19 v preteklem letu zaznali nove priložnosti. V Sloveniji je bil delež takih zgodnjih podjetnikov 32 \%, tolikšen kot v povprečju evropskih držav.

Slika 4.7: Zgodnji podjetniki, ki so v krizi zaradi covida-19 zaznali nove priložnosti (v evropskih državah GEM)

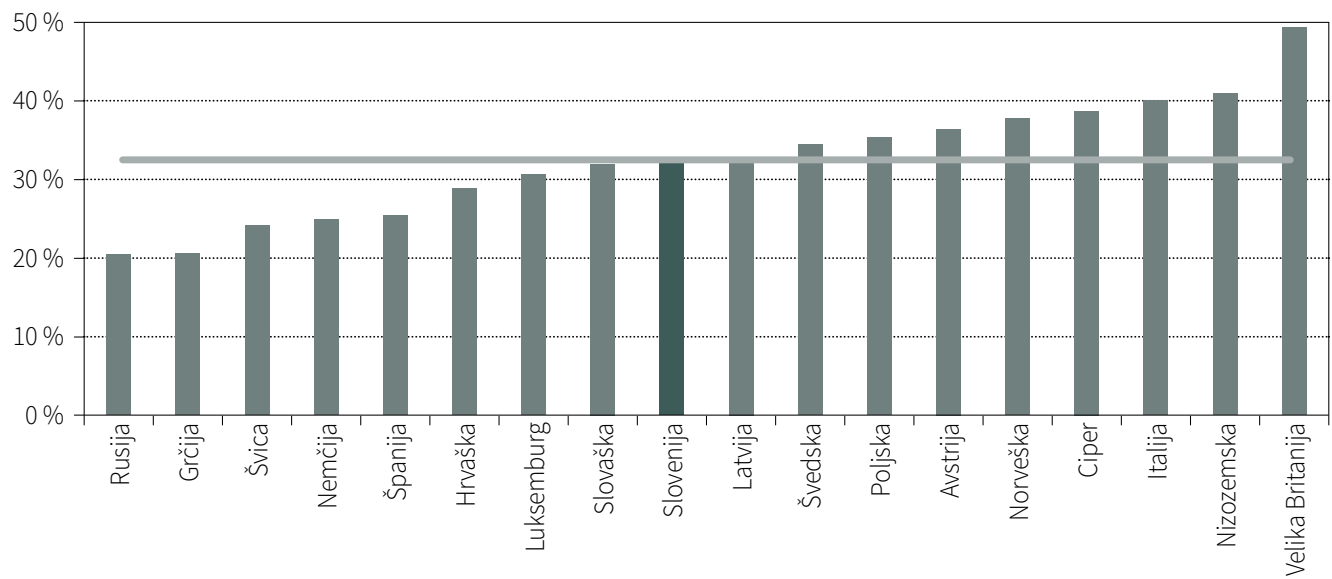


Primerjava posameznih motivov za podjetništvo med slovenskimi zgodnjimi podjetniki in povprečjem evropskih držav je prikazana na sliki 4.8. Zgodnji podjetniki v Sloveniji več kot v povprečju $\checkmark$ Evropi sledijo motivoma ustvarjanja razlike v svetu in preživetja, ker so službe redke. Ustvarjanju premoženja sledijo podjetniki v povprečju v Evropi enako kot v Sloveniji. V Sloveniji pa jih kar za 10 odstotnih točk manj sledi razvoju družinske tradicije v primerjavi z zgodnjimi podjetniki v Evropi.

Slika 4.8: Motivacija za podjetništvo v Sloveniji in povprečju evropskih držav
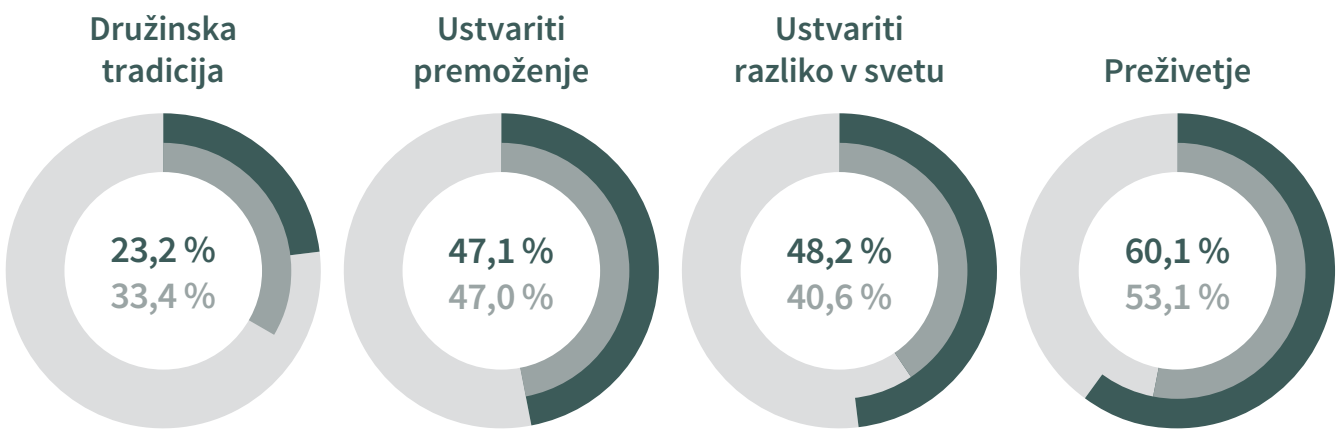

Slovenija Evropa

GEM Slovenija 2020, APS

\subsection{Ustaljeni podjetniki}

Ustaljeni podjetniki so tisti, ki imajo podjetje več kot tri leta in pol, sledijo pa novim podjetnikom z vidika proučevanja podjetniškega procesa. Čeprav je v populaciji podjetij veliko tudi takih, ki so ustaljena, stara, je podjetniški proces dinamičen, kar pomeni, da se nenehno dogaja, da podjetja tudi prenehajo poslovati. V populaciji podjetij je tudi majhen delež zelo starih podjetij (Renko, 2013; Thiele, Fellnhofer, 2015). Kljub temu, da imajo ustaljeni podjetniki več izkušenj z vodenjem podjetja, da imajo razvite proizvode in trg ter blagovne znamke, pa dinamika na trgu še zmeraj ustvarja potrebe po nenehnem spreminjanju poslovanja, inoviranju ne le proizvodov, ampak tudi procesov, tehnologije in celotnega poslovnega modela (Coetzer et al., 2017). Vztrajnost ustaljenih podjetnikov se kaže z njihovim nenehnim vzdrževanjem pozitivne podjetniške motivacije in nenehnim aktivnim angažiranjem $v$ obstoječem podjetju kljub nekaterim alternativam (na primer zaposlitvi, novi poslovni priložnosti). Zato je prav vztrajnost element, ki je za ustaljene podjetnike ključnega pomena pri iskanju in izkoriščanju poslovnih priložnosti v okviru obstoječega podjetja (Caliendo et al., 2020). Čeprav del ustaljenih podjetij preneha poslovati, je njihova dinamika bistveno manjša v primerjavi z začetnimi fazami podjetniškega procesa (OECD, 2017a). Ob tem je treba upoštevati tudi značilnosti nacionalnega gospodarstva in podjetniškega ekosistema, ki vpliva na prisotnost ustaljenih podjetij. Tako je na primer v nizkodohodkovnih državah GEM povprečno 12,4 \% ustaljenih podjetnikov, v visokodohodkovnih pa v povprečju 6,8\%. V evropskih državah je to povprečje 6,9 \%, za vse sodelujoče države pa je prikazano na sliki 4.9. Največ ustaljenih podjetnikov je v Grčiji (14,6 \%), na Poljskem (12,2\%) in v Latviji (11,1\%). Najmanj jih je v Italiji (2,2\%), Luksemburgu (3,6\%) in na Norveškem (4,1\%). Razlike med posameznimi državami v Evropi so precej velike, k čemur je morda prispevala tudi kriza zaradi covida-19, saj so se tako z vidika prizadetosti posameznih gospodarstev kot z vidika razlik v podpori podjetij države nanjo različno odzvale. 
Slika 4.9: Odstotek ustaljenih podjetnikov med odraslim prebivalstvom (v evropskih državah GEM)

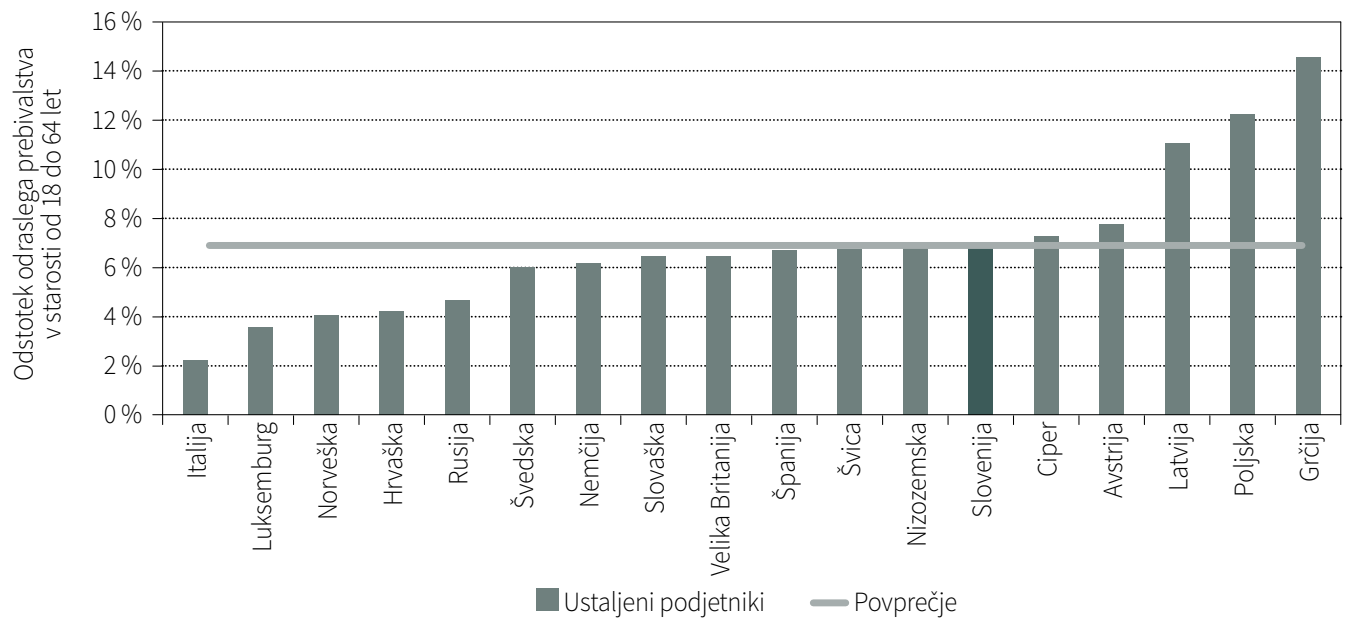

GEM Slovenija 2020, APS

Primerjava zgodnje podjetniške aktivnosti in ustaljenih podjetnikov kaže, da je v devetih državah sveta raven celotne zgodnje podjetniške aktivnosti (indeks TEA) več kot trikrat višja od stopnje ustaljenih podjetnikov. To vključuje štiri države na Bližnjem vzhodu in v Afriki (Egipt, Južna Afrika, Oman in Katar) in pet v Latinski Ameriki in na Karibih (Mehika, Portoriko, Kolumbija, Panama in Čile). Na drugi strani ima 12 držav ravni celotne zgodnje podjetniške aktivnosti nižje od ravni ustaljenih podjetnikov (Italija, Poljska, Španija, Severna Makedonija, Slovenija, Grčija, Švica, Nizozemska, Madagaskar, Pakistan, Japonska in Tajvan).

Primerjava ustaljenih podjetnikov v izbranih skupinah držav, ki so prikazane na sliki 4.10, kaže, da so razlike med posameznimi skupinami minimalne in precej manjše, kot smo jih zaznavali v preteklih letih. V vseh državah GEM je bilo v letu 2020 med odraslim prebivalstvom 7,5 \% ustaljenih podjetnikov (leta 2019 pa kar 12,3 \%), v evropskih državah pa jih je bilo 6,9 \% (7,8 \% v letu 2019). VSloveniji smo tudi v letu 2020 imeli delež ustaljenih podjetnikov nad evropskim povprečjem (7\%), vendar manj kot leto poprej (8,5 \%). Čeprav ti podjetniki predstavljajo stabilnejši del gospodarstva, saj spadajo med zrelejša podjetja, pa smo v letu 2020 zaznali njihov upad, ki je bil največji prav na globalni ravni.

Slika 4.10: Ustaljeni podjetniki v izbranih skupinah držav

\section{Ustaljeni podjetniki}

Slovenija

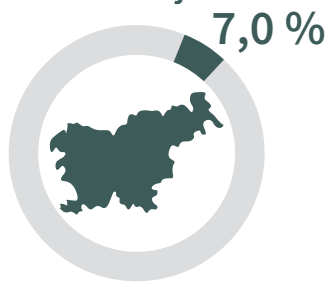

Evropa

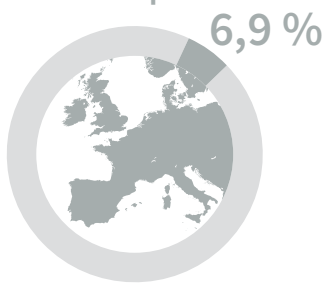

Države GEM

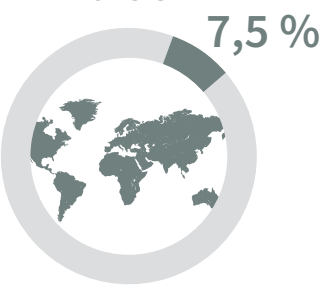


Časovna analiza ustaljenih podjetnikov v Sloveniji kaže, da njihov delež niha, vendar se je v zadnjih petih letih ustalil na slabih $7 \%$ z izjemo leta 2019. V letih od 2010 do 2015 je bil ta delež v povprečju manjši za približno $2 \%$.

V Sloveniji ravni ustaljenih podjetnikov precej nihajo v času, kar je prikazano na sliki 4.11. V letu 2019 je bil njihov delež največji v zadnjem desetletju in se je od leta 2018 povečal s 6,8 \% na 8,5 \%. Tak rezultat je verjetno tudi posledica ugodnih gospodarskih razmer, ki so v letu 2019 izkazovale pozitivno sliko (UMAR, 2019). Najmanjši delež ustaljenih podjetnikov je bil $\vee$ preteklih letih (najmanjši, 4,2 \%, v letu 2015), ko tudi gospodarske razmere niso bile tako ugodne, kot so v zadnjih letih. Kot ugotavlja UMAR (Tavčar, 2021), so sedanja kriza in posledično sprejeti zajezitveni ukrepi prepovedi oziroma oteženega delovanja vrste gospodarskih dejavnosti bistveno bolj prizadeli storitveni sektor in samostojne podjetnike (tržne storitvene dejavnosti - najbolj gostinstvo, druge raznovrstne poslovne dejavnosti ter kulturne, razvedrilne in rekreacijske dejavnosti), vendar se zaradi trajanja ukrepov negativni učinki na poslovanje trenutno še ne kažejo.

Slika 4.11: Ustaljeni podjetniki kot odstotek odraslega prebivalstva v Sloveniji v letih od 2010 do 2020

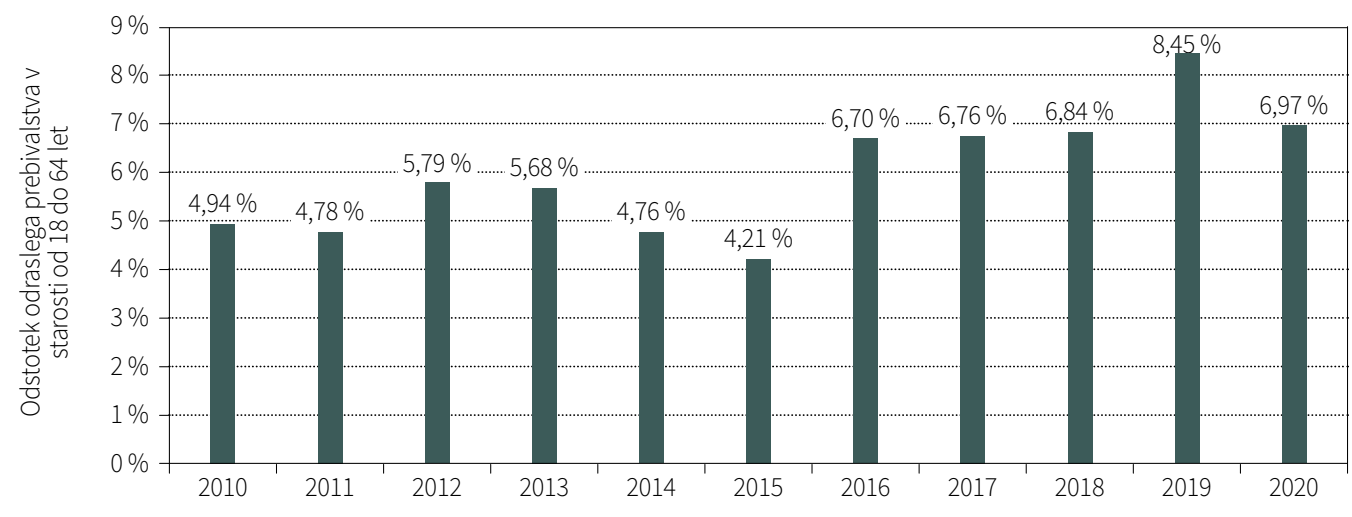

\subsection{Podjetniška aktivnost zaposlenih}

Eden izmed pomembnih vidikov podjetništva je tudi podjetništvo $\vee$ obstoječih, ustaljenih podjetjih, ki so velikokrat osredotočena na rutinski način dela in na zadovoljevanje obstoječih odjemalcev z razvitimi proizvodi na trenutnih trgih. Toda takšen način dela zaradi dinamike $v$ okolju podjetja hitro postane nesprejemljiv (Alam et al., 2020). Takrat se pojavijo potrebe po ustreznih spremembah v poslovanju podjetja, ki zahtevajo inovativnost na različnih področjih, od proizvodnega do organizacijskega in tehnološkega, vendar so za implementiranje vseh sprememb potrebni posamezniki, ki jih vodijo. To so notranji podjetniki (McMullen, Dimov, 2013). V okviru raziskave GEM merimo podjetniško aktivnost zaposlenih že od leta 2011. Notranji podjetniki so tisti zaposleni, ki podjetniške aktivnosti v okviru obstoječih podjetij razvijajo, vodijo in implementirajo. Podjetniška aktivnost zaposlenih v raziskavi GEM vključuje široko in ozko opredelitev. Široka opredelitev pomeni vključenost zaposlenih v podjetniško aktivnost in vodilno vlogo v preteklih treh letih, ozka pa trenutno vključenost zaposlenih $v$ podjetniško aktivnost in vodilno vlogo (Bosma et al., 2012). Podjetniška aktivnost zaposlenih je razdeljena na dve fazi, na fazo razvoja 
idej ter fazo priprave in izkoriščanja izdelka ali storitve. Praviloma je več podjetniške aktivnosti zaposlenih v razvitejših gospodarstvih, saj je v njih na voljo dovolj velikih, ustaljenih podjetij, ki omogočajo delovanje notranjih podjetnikov. Ti posamezniki so za podjetje redek in dragocen resurs, saj morajo imeti posebne lastnosti - so inovativni, proaktivno delujejo in prevzemajo tveganja (Chakrabarty, 2020), hkrati pa so tudi zaposleni, ki imajo med drugim pravico do varne zaposlitve in posebnih nagrad v okviru svojega notranjepodjetniškega angažiranja. V evropskih državah (slika 4.12) je sicer prisotnost notranjih podjetnikov med posameznimi državami zelo različna: najmanj jih najdemo v Rusiji (0,4\%), Italiji (0,7\%) in Španiji (0,8\%), največ pa v Nemčiji (6,4\%), na Hrvaškem (6,4 \%) in Švedskem (6,2\%).

Slika 4.12: Podjetniška aktivnost zaposlenih kot odstotek odrasle populacije (v evropskih državah GEM)

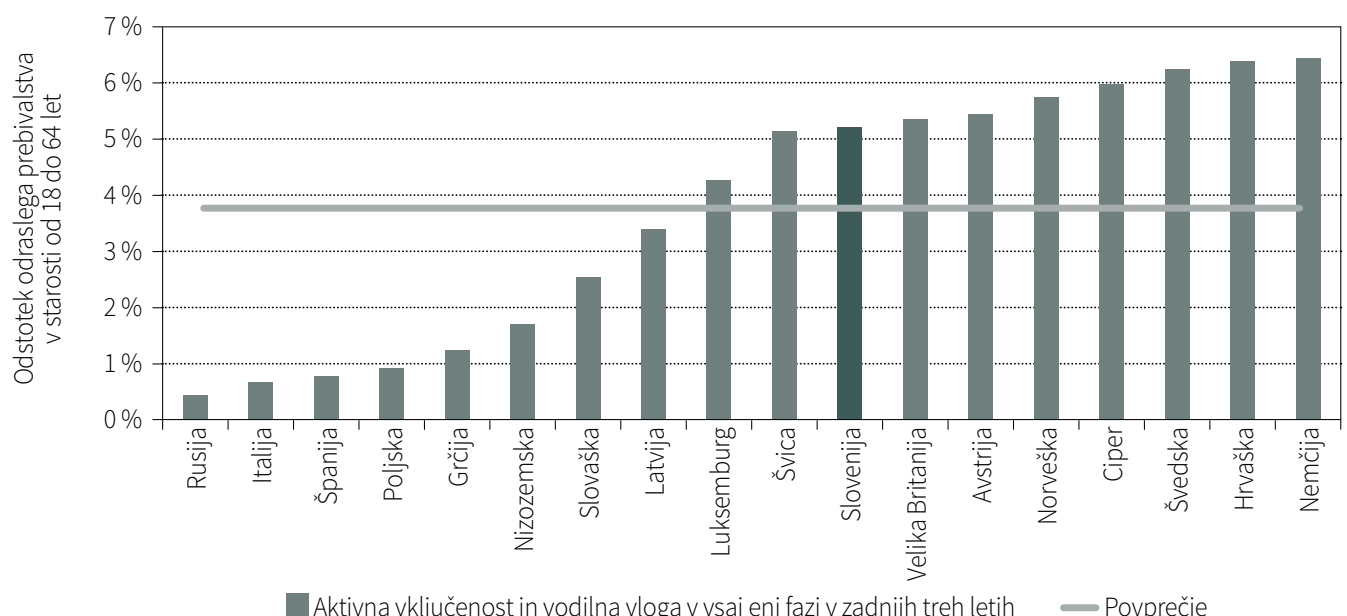

GEM Slovenija 2020, APS

Slovenija že tradicionalno izkazuje nadpovprečne stopnje podjetniške aktivnosti zaposlenih, v letu 2020 jih je bilo med odraslim prebivalstvom 5,2 \% (povprečje evropskih držav je 3,8 \%). V tabeli 4.5 so prikazani podrobnejši podatki o podjetniški aktivnosti zaposlenih z vidika širše in ožje opredelitve ter vlog, ki jo ti posamezniki prevzemajo. V letu 2020 se je delež podjetnih zaposlenih v Sloveniji zmanjšal v primerjavi z letom 2019, vendar smo še zmeraj nad povprečjem evropskih držav. 
Tabela 4.5: Podjetniška aktivnost zaposlenih v Sloveniji v letih od 2011 do 2020, GEM Slovenija 2020, APS

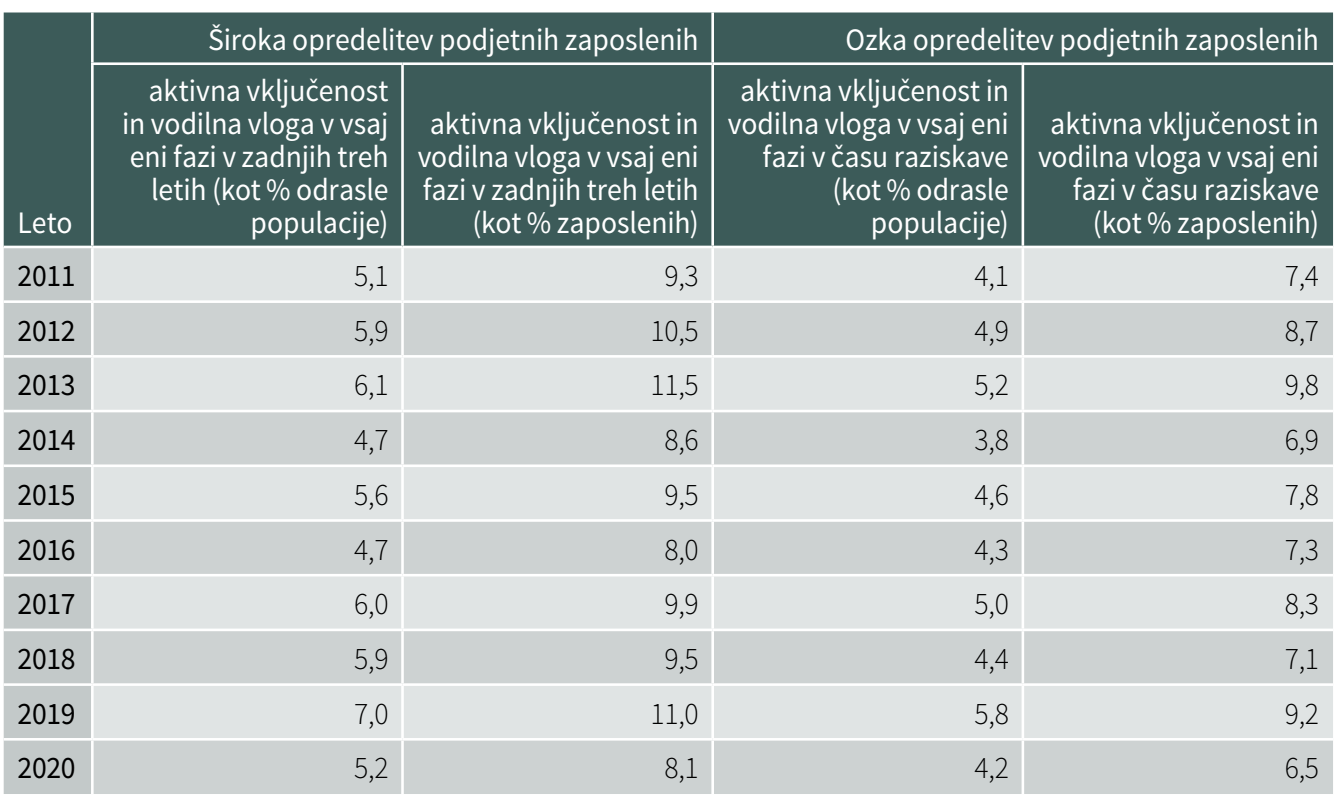

Šele drugo leto zapored pa v okviru raziskave GEM proučujemo tudi tako imenovano sponzorirano zgodnjo podjetniško aktivnost. Merimo jo z vprašanjem: »Ali ste trenutno sami ali skupaj z drugimi lastnik podjetja, ki ga pomagate upravljati za vašega delodajalca v okviru vaše redne zaposlitve?« Z odgovorom analiziramo nastajajoče, nove in uveljavljene lastnike podjetij - menedžerje, katerih posel je samostojen ali neodvisen od večjega podjetja, in tiste, katerih poslovanje se sponzorira s skupnim lastništvom delodajalca posameznika (sponzorirani TEA). Na globalni ravni je delež sponzoriranega TEA zelo različen, za evropske države pa je prikazan na sliki 4.13. V evropskih državah je sponzorirane zgodnje podjetniške aktivnosti v povprečju 2,3 \%, kar je manj v primerjavi z letom poprej (2,9 \%). Največ je najdemo na Hrvaškem (7,1 \%) in Nizozemskem (5,2 \%), najmanj pa na Norveškem (0,5\%) in Poljskem (0,8\%). Slovenija je po kazalniku zgodnje podjetniške aktivnosti $(1,0 \%)$ na nezavidljivem 15. mestu, takoj za Poljsko. 
Slika 4.13: Sponzorirana zgodnja podjetniška aktivnost kot odstotek odrasle populacije (v evropskih državah GEM)

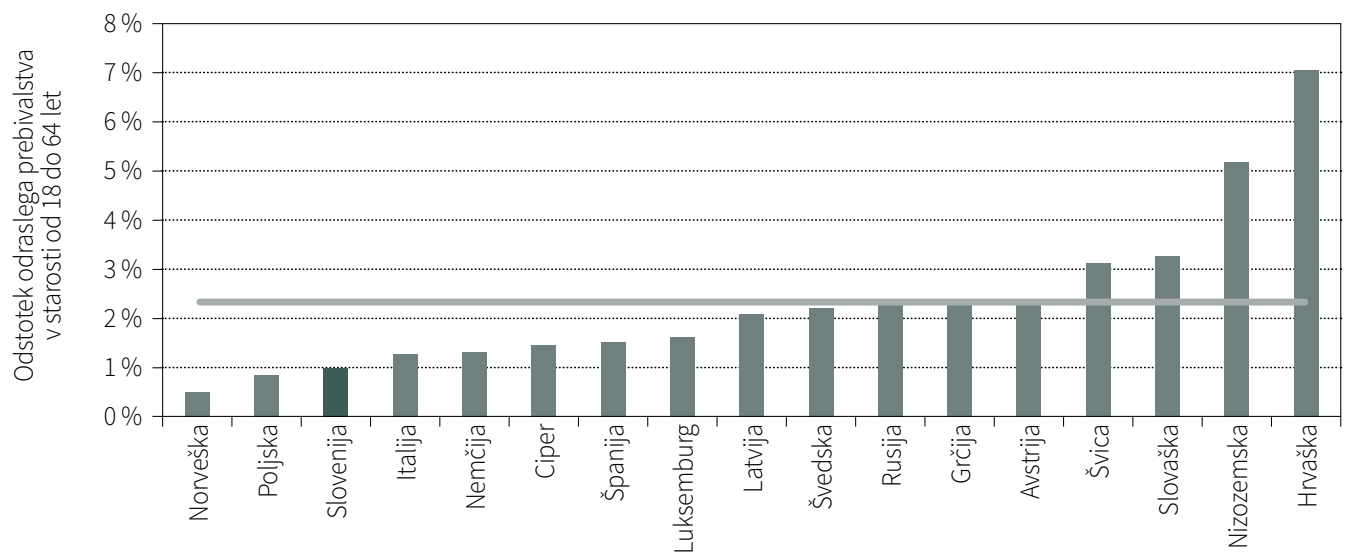

Sponzorirani TEA $\longrightarrow$ Povprečje

\subsection{Izstop podjetnikov}

Vsak podjetnik ima določen motiv za izstop iz podjetništva, neko žetveno strategijo, kaj želi s podjetjem po določenem času narediti. Izstop podjetnika je zaključna faza $v$ podjetniškem procesu. Izstop podjetnika ne pomeni, da je podjetje propadlo, ampak gre lahko za njegovo zavestno odločitev, da izstopi iz podjetja (Pinkovetskaia et al., 2020). Tudi vidikov izstopa je veliko, med njimi so na primer izstop s trga, izstop zaradi nasledstva, prodaja (DeTienne et al., 2015). V okviru raziskave GEM proučujemo, koliko podjetnikov med odraslim prebivalstvom je v zadnjih 12 mesecih izstopilo iz podjetniške aktivnosti, ob tem pa tudi, ali se po izstopu podjetnika posel nadaljuje ali ne.

Največ izstopov podjetnikov je bilo med evropskimi državami na Slovaškem (5,8\%), Nizozemskem (5,1 \%) in Hrvaškem (4,5\%) (slika 4.14), najmanj izstopov pa beležijo Italija (0,5%), Španija (1,3 \%) in Švica (1,5\%). Delež izstopov se v povprečju glede na preteklo leto ni povečal. Slovenija beleži 1,6 \% izstopov, kar je malo manj kot leto poprej (1,9\%). Kljub krizi zaradi covida-19, ko se je že v letu 2020 velik del podjetij srečal z omejitvami dejavnosti in zmanjšanim povpraševanjem, pa so številni ciljno usmerjeni intervencijski ukrepi države, finančna stabilnost in dobri poslovni rezultati vseh poslovnih subjektov pred krizo najbrž razlog, da kazalniki plačilne sposobnosti slovenskih poslovnih subjektov za leto 2020 ne prikazujejo njene razsežnosti (Tavčar, 2021). Veliko ukrepov, kot so zakonski moratoriji, finančna sredstva države in omogočen dodaten čas podjetjem za okrevanje, deloma še vedno velja, vendar pa UMAR ugotavlja (Tavčar, 2021), da lahko v naslednjih letih pride do večjega poslabšanja insolventnosti. Dodajajo tudi, da bi lahko sedanja kriza imela v prihodnosti globlje negativne posledice na poslovne rezultate gospodarskih subjektov, kot kažejo trenutno razpoložljivi podatki za leto 2020. Prav aktivni ukrepi pa so najverjetneje tudi razlog, da je poslovanje kljub krizi opustilo manj podjetnikov. 
Slika 4.14: Izstop podjetnika $v$ zadnjih 12 mesecih z nadaljevanjem in brez nadaljevanja posla ( $\mathrm{V}$ evropskih državah GEM)

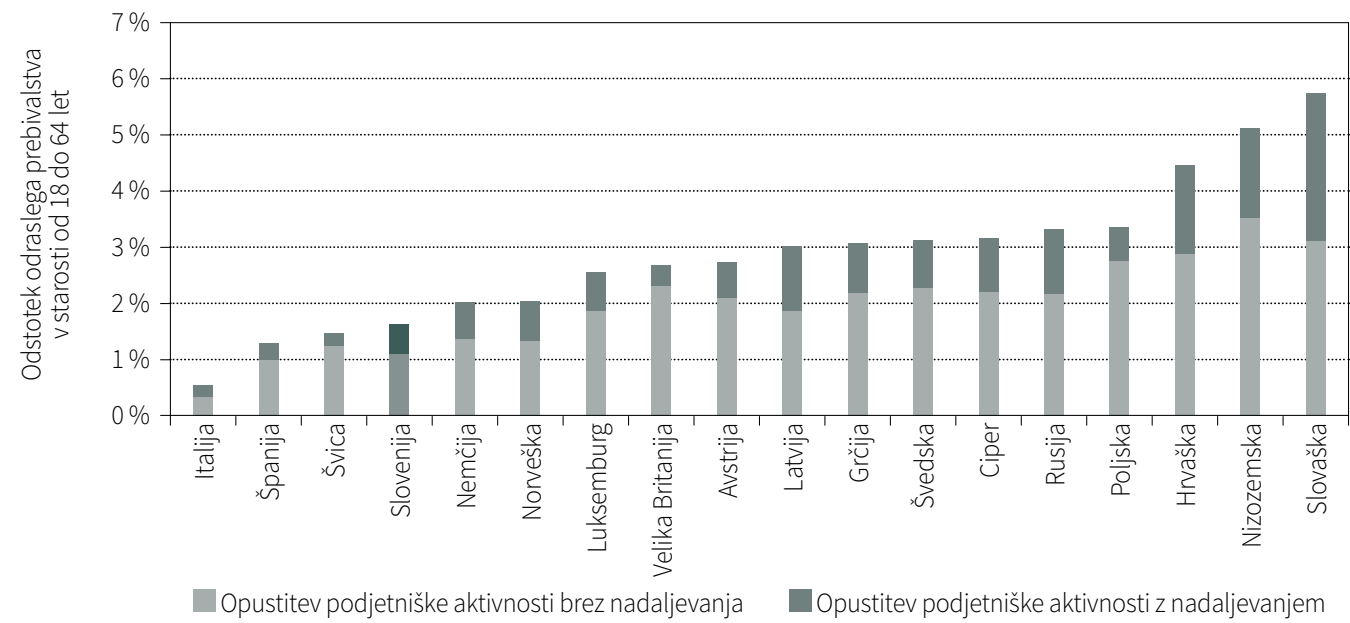

GEM Slovenija 2020, APS

Ob tem v raziskavi GEM proučujemo tudi, koliko podjetij je po izstopu podjetnika nadaljevalo poslovanje in koliko jih je povsem prenehalo. $V$ povprečju je bilo $v$ evropskih državah brez nadaljevanja poslovanja $2 \%$ izstopov, z nadaljevanjem pa približno tretjina, le 0,9 \%. V Sloveniji je bilo izstopov podjetnikov iz podjetniškega procesa brez nadaljevanja posla 1,1 \%, z nadaljevanjem pa 0,5\%. Razmerje se je glede na preteklo leto izboljšalo, pa tudi celoten delež izstopov je bil manjši kot leto poprej. Glede na to, da je kljub izstopu podjetnika pomembno ohranjati uspešna podjetja, da naprej poslujejo, ostaja v Sloveniji izziv, kako to razmerje izboljšati. Odločitev podjetnika o izstopu in zaprtju podjetja je namreč velikokrat povezana z njegovimi osebnimi preferencami. Podjetja pogosto tudi ne želi predati nikomur drugemu, saj ga je sam razvijal velik del svoje kariere. Pomemben vidik te problematike predstavlja slabo razvit trg transferja podjetij v Sloveniji, še zlasti če ne gre za medgeneracijski transfer, ampak za transfer prodaje podjetja nekomu tretjemu. Podrobnejši vpogled v dogajanje na tem področju nam podaja tudi vpogled v posamezne razloge za izstop podjetnikov.

$\checkmark$ raziskavi GEM proučujemo deset skupin razlogov, ki so za Slovenijo in izbrane skupine držav prikazani v tabeli 4.6. V letu 2020 je bila dodana nova skupina razlogov, pandemija covida-19. Ta razlog je bil v povprečju v svetu pričakovano najpogostejši razlog za izstop iz podjetja (27\%), naslednji so bili nedobičkonosno poslovanje podjetja (23\%) in podjetnikovi osebni razlogi (12\%).

V Sloveniji so prevladujoči razlogi za izstop že tradicionalno drugačni od povprečja v svetu. Tako pri nas prevladujejo razlogi drugega dela ali poslovne priložnosti $(22,8 \%)$, osebni razlogi $(22,5 \%)$ in upokojitev (15,3\%). Pandemija covida-19 je v Sloveniji šele na četrtem mestu in je razlog za 12,1 \% izstopov. V skladu s prejšnjimi podatki o velikem deležu opustitev poslovanja brez naslednika je tudi rezultat, da nihče med respondenti v Sloveniji kot razlog ni navedel priložnosti prodati podjetje. To kaže na zelo majhno dinamiko prodaje in nakupov (transferjev poslovanja) podjetij v gospodarstvu. 
Tabela 4.6: Razlogi za izstop podjetnika po skupinah držav, GEM Slovenija 2020, APS

\begin{tabular}{|c|c|c|c|c|}
\hline & Slovenija & GEM & $\begin{array}{r}\text { Visokodohodkovne } \\
\text { države }\end{array}$ & $\begin{array}{r}\text { Evropske } \\
\text { države }\end{array}$ \\
\hline Podjetje ni bilo dobičkonosno & $4,63 \%$ & $23,03 \%$ & $20,56 \%$ & $20,20 \%$ \\
\hline Drugo delo ali poslovna priložnost & $22,79 \%$ & $8,00 \%$ & $9,50 \%$ & $12,24 \%$ \\
\hline Vladne/davčne politike, birokracija & $9,26 \%$ & $3,24 \%$ & $3,81 \%$ & $5,21 \%$ \\
\hline Osebni razlogi & $22,53 \%$ & $12,01 \%$ & $13,27 \%$ & $13,57 \%$ \\
\hline Finančni razlogi & $0,00 \%$ & $9,84 \%$ & $8,78 \%$ & $8,24 \%$ \\
\hline Upokojitev & $15,29 \%$ & $3,42 \%$ & $4,51 \%$ & $6,64 \%$ \\
\hline Opustitev je bila planirana vnaprej & $4,63 \%$ & $2,92 \%$ & $3,21 \%$ & $3,76 \%$ \\
\hline Priložnost prodati podjetje & $0,00 \%$ & $4,14 \%$ & $4,65 \%$ & $5,19 \%$ \\
\hline Neki nepričakovani dogodek & $8,76 \%$ & $6,37 \%$ & $4,55 \%$ & $4,86 \%$ \\
\hline Pandemija covida-19 & $12,11 \%$ & $27,02 \%$ & $27,17 \%$ & $20,08 \%$ \\
\hline
\end{tabular}

Vse razloge, ki jih proučujemo, smo združili v štiri skupine razlogov (slika 4.15). Prva skupina razlogov za izstop, ki jo sestavljajo prodaja podjetja, izkoriščanje druge priložnosti, upokojitev ali osebni razlogi podjetnika, v Sloveniji predstavlja 65 \% vseh izstopov. Te razloge bi lahko imenovali tudi osebni razlogi podjetnika, saj se nanašajo na osebne, notranje, intimne odločitve podjetnika o izstopu. Druga skupina razlogov, ki bi jo lahko imenovali finančni razlogi in jo sestavljajo nedobičkonosnost poslovanja, finančni razlogi ali drugi nepričakovani dogodki, predstavlja 13,4 \% vseh izstopov v Sloveniji. Ti razlogi se nanašajo na neuspešnost poslovanja podjetja, ki vodi $\checkmark$ njegovo zaprtje ali propad. Tretjo skupino sestavljajo vladne in davčne politike ter birokracija in predstavljajo 9,3\% vseh razlogov za izstop podjetnikov. To je skupina zunanjih razlogov, ki izvirajo iz okolja podjetja in na katere ima podjetje tudi najmanj vpliva. Zadnjo skupino razlogov za izstop predstavlja pandemija covida-19, ki pa, kot rečeno, v Sloveniji v primerjavi s svetom ni ključni razlog za izstop podjetnika iz podjetja, verjetno tudi zaradi obsežne podpore, ki jo v času krize izvaja Vlada RS, in sicer v obliki obsežnega niza protikoronskih zakonov s finančnimi ukrepi za blažitev posledic pandemije (Vlada RS, 2021). V njih je, recimo, vrsta ukrepov namenjenih financiranju stroškov poslovanja podjetja in podjetnika, ki lahko preprečujejo odločitev podjetnika o izstopu ali pa izstop prestavljajo v prihodnost.

Slika 4.15: Glavne skupine razlogov za prenehanje poslovanja v Sloveniji

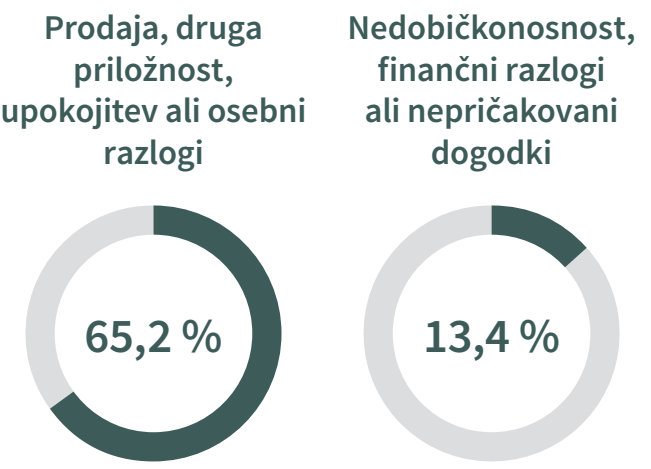

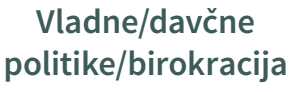

Pandemija
covida-19

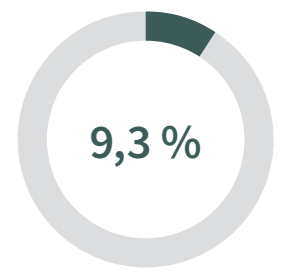

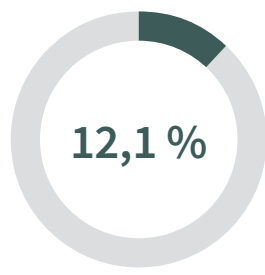





\section{Demografske značilnosti slovenskega podjetništva}

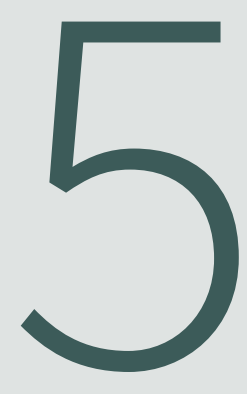

\section{Ključna spoznanja}

- V letu pandemije je bila v Sloveniji zgodaj podjetniško najbolj aktivna starostna skupina mladih v starosti od 25 do 34 let. Obenem se je v tej starostni skupini znatno zmanjšal delež žensk.

- Znatno je upadla zgodnja podjetniška aktivnost starostne skupine od 45 do 54 let (s 25,6 \% na $14,11 \%)$. Razlog za tako izrazit upad gre pripisati po eni strani višjim oportunitetnim stroškom zaradi splošne negotovosti, po drugi strani pa težnji po izkoriščanju varnega zavetja v obstoječih zaposlitvah in pomoči državnih intervencij v času krize.

- Najpogostejši motiv za ustanavljanje podjetij je bil pri obeh spolih preživetveni motiv, ki je najizraziteje prisoten pri najmlajših zgodnjih podjetnikih. S starostjo podjetnikov narašča težnja po ustvarjanju premoženja oziroma povečevanju dohodka, želja po spreminjanju sveta pa se manjša.

- Zgodnja podjetniška aktivnost žensk se v Sloveniji povečuje že tretje leto zapovrstjo. V letih od 2018 do 2020 se je povečala za skoraj 10 odstotnih točk, na 38,3\%, in tako prvič v opazovanem obdobju presegla evropsko povprečje (38,1\%).

- Preseneča podatek, da so v pandemskem letu ženske v kar dveh starostnih skupinah presegle raven zgodnje podjetniške aktivnosti moških, in sicer v najmlajši in najstarejši starostni skupini, kjer je vrzel med spoloma v relativnem smislu tudi največja. 
V letu 2020 smo bili na trgu dela priča precejšnjim preobratom zaradi upočasnitve ali zaustavitve večine gospodarskih dejavnosti, namen česar je bila zajezitev širjenja covida-19. Močno se je povečalo število prijavljenih brezposelnih, zmanjšalo povpraševanje po delavcih in zaposlovanje brezposelnih (ZRSZ, 2020a), obenem sta upadli tudi zgodnja in ustaljena podjetniška aktivnost (zgodnja s 7,8 \% na 5,97 \%, ustaljena z 8,45 \% na 6,97 \%). Poleti je bilo zaznati nekoliko pozitivnejše kazalce, povezane s trgom dela (razpisana prosta delovna mesta), zadnji podatki pa kažejo, da se je v primerjavi z decembrom 2019 brezposelnost povečala za kar 15,9\% (ZRSZ, 2020b). Jesenski ukrepi za zajezitev širjenja covida-19 imajo močan vpliv na gospodarska gibanja in prinašajo precejšnjo trenutno negotovost, kar se seveda odraža tudi na podjetniški aktivnosti prebivalstva. UMAR-jeva ocena padca gospodarske aktivnosti za leto 2020 je znašala 6,7 \% (UMAR, 2020a). Za leto 2021 se napoveduje 5,1-odstotna gospodarska rast, za leto 2022 pa 3,2-odstotna rast. Posledično lahko pričakujemo tudi porast podjetniške aktivnosti, saj bo to verjetno ključni del gospodarskega okrevanja v obdobju po pandemiji. Da bi oblikovalci politike v tem zahtevnem obdobju lahko sprejemali ustrezne odločitve, potrebujejo verodostojne podatke (Ionescu-Somers in Tarnawa, 2020). Dejstvo namreč je, da se različne demografske skupine prebivalstva soočajo z raznolikimi izzivi in situacijami, saj pandemija ni prizadela vseh v enaki meri. Ključen izziv predstavljajo starejši, manj izobraženi, mladi in ženske. Zato v nadaljevanju prikazujemo zgodnjo in ustaljeno podjetniško aktivnost po starostnih skupinah in spolu, za natančnejši vpogled pa predstavljamo še izobrazbeno in dohodkovno strukturo nastajajočih, novih in ustaljenih podjetnikov. Posledice covida-19 ter demografske spremembe (staranje in krčenje delovne sile, povečana mobilnost) in tehnološki razvoj (robotizacija, avtomatizacija, digitalizacija z uporabo umetne inteligence) bodo bistveno spremenili trg dela (ZRSZ, 2020c) in s tem tudi priložnosti za podjetniško angažiranost v naslednjih letih.

\subsection{Starost}

Dosedanje teoretične in empirične raziskave kažejo, da se pripravljenost in namen za ustanovitev podjetja s starostjo zmanjšujeta (Van Praag in Van Ophem, 1995) zaradi naraščajočih oportunitetnih stroškov (Lévesque in Minniti, 2006). Obenem se priložnost za ustanovitev podjetja s starostjo povečuje zaradi akumuliranega fizičnega, družbenega in človeškega kapitala (Lee in Vouchilas, 2016). Gre torej za nasprotujoča si fenomena, katerih posledica je nelinearni starostni trend podjetništva, ki dosega vrh med 35. in 44. letom (Parker, 2009).

V Sloveniji sta najpogostejši starostni obdobji za ustanavljanje podjetij obdobji od 25. do 34. ter od 35. do 44. leta. To je dolgo obdobje dvajsetih let, ki za večino ljudi predstavlja čas od začetka do sredine kariere. Do sredine karierne poti so si posamezniki nabrali izkušnje in vire ali sposobnost pridobivanja virov ter so imeli čas za izgradnjo mrež in verodostojnosti (slika 5.1). Po drugi strani pa tisti v zgodnjih kariernih letih najverjetneje nimajo večjih finančnih obveznosti, na primer z otroki ali hipotekami, in je to razlog, da se laže odločajo za podjetniško udejstvovanje. V tem starostnem obdobju običajno še niso vstopili v visokozaslužno fazo svoje kariere, zaradi katere bi se težko uprli stabilnim in dobro plačanim delovnim mestom. Obenem si tudi še niso nabrali življenjskih izkušenj, zaradi katerih bi bili lahko bolj previdni in zato manj naklonjeni tveganim podjetniškim izzivom (Kelley et al., 2020).

Prav zaradi naštetih značilnosti v Sloveniji vse bolj podpiramo mlade podjetnike, čeravno bo nadaljnja analiza pokazala, da obenem precej zaostajamo po deležu zgodnje podjetniške aktivnosti med najmlajšimi (od 18. do 24. leta). Starejše starostne skupine (od 45 do 55 let in od 55 do 64 let) pogosteje vodijo ustaljena podjetja (slika 5.1). Prelomna točka se pojavlja v starostnem razponu od 35 do 44 let, ko začne strmo upadati zgodnja podjetniška aktivnost, ustaljene podjetniške aktivnosti pa beležimo v starejših starostnih skupinah precej več. 
Slika 5.1: Podjetniška aktivnost v Sloveniji glede na starost

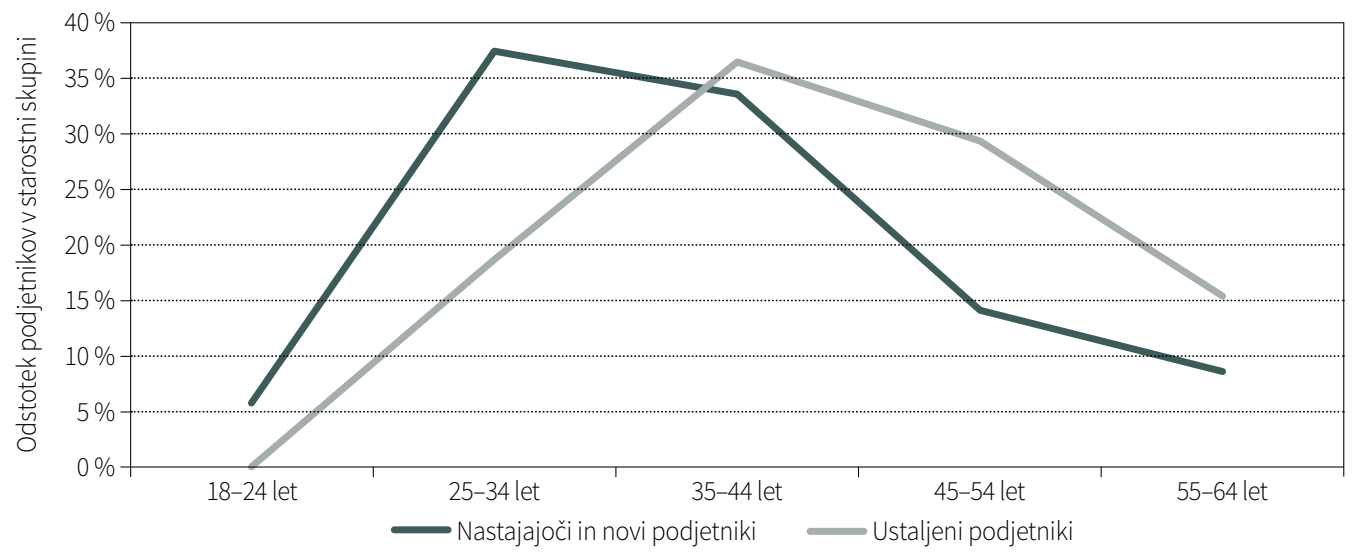

GEM Slovenija 2020, APS

V tabeli 5.1 prikazujemo zgodnjo podjetniško aktivnost po starostnih skupinah za Slovenijo in proučevane skupine držav (države GEM, visokodohodkovna gospodarstva in evropske države). Struktura po starostnih razredih razkriva precejšen zaostanek najmlajše starostne skupine, mladostnikov v starosti od 18 do 24 let, ki so v poprečju skoraj trikrat manj zgodaj podjetniško aktivni v primerjavi z vrstniki iz proučevanih skupin držav. Razlog gre najverjetneje pripisati množični vključenosti mladih v srednješolsko in terciarno izobraževanje v Sloveniji. Kot že rečeno, je zgodaj podjetniško najaktivnejša starostna skupina mladih $\vee$ starosti od 25 do 34 let. $\vee$ tej starostni skupini je v letu krize zaradi covida-19 Slovenija kar precej nad povprečjem proučevanih držav (od 7,24 \% nad povprečjem evropskih držav do 5,39 \% nad povprečjem vseh proučevanih GEM držav). Porast zgodnje podjetniške aktivnosti te skupine mladih bi lahko pripisali njihovi ustreznejši pripravljenosti za izkoriščanje podjetniških priložnosti, povezanih z delom na daljavo, in ustreznejšo digitalno pripravljenostjo, ki je v času epidemije postala ključna konkurenčna prednost. Obdobje krize je namreč v povezavi z obstoječimi megatrendi znatno spremenilo osnovne predpostavke delovanja trgov in družb ter posledično zahteva radikalno (digitalno in trajnostno) preobrazbo v podjetniškem sektorju (UMAR, 2020b).

Medtem ko v primerjavi s preteklimi leti ni opaznih razlik v starostni strukturi nastajajočih in novih podjetnikov $\vee$ proučevanih skupinah držav, za Slovenijo v letu epidemije ugotavljamo znaten upad zgodnje podjetniške aktivnosti v starostni skupini od 45 do 54 let (s 25,6 \% na 14,11\%). Vse preostale starostne skupine v Sloveniji posledično izkazujejo v letu 2020 relativen porast zgodnje podjetniške aktivnosti. Razlog za tako izrazit upad zgodnje podjetniške aktivnosti v skupini, ki je sicer potencialno zelo obetavna, saj gre za posameznike v zrelem obdobju kariere, ki posedujejo ustrezna znanja in veščine, z leti pa so si že ustvarili potrebne mreže povezav za potencialno uspešno samostojno podjetniško pot, gre pripisati po eni strani višjim oportunitetnim stroškom zaradi splošne negotovosti, po drugi strani pa težnji po izkoriščanju varnega zavetja v obstoječih zaposlitvah ter pomoči državnih intervencij v času krize. 
Tabela 5.1: Odstotek nastajajočih in novih podjetnikov po starostnih razredih in skupinah držav, GEM Slovenija 2020, APS

\begin{tabular}{|c|c|c|c|c|}
\hline \multirow[b]{2}{*}{ Starost podjetnikov } & \multicolumn{4}{|c|}{ Odstotek nastajajočih in novih podjetnikov } \\
\hline & Slovenija & GEM & $\begin{array}{r}\text { visokodohodkovna } \\
\text { gospodarstva }\end{array}$ & evropske države \\
\hline 18-24 let & 5,75 & 17,33 & 15,12 & 14,61 \\
\hline 25-34 let & 37,49 & 32,10 & 30,95 & 30,25 \\
\hline 35-44 let & 33,63 & 24,37 & 25,24 & 24,90 \\
\hline 45-54 let & 14,11 & 16,62 & 18,19 & 19,42 \\
\hline 55-64 let & 8,58 & 9,58 & 10,49 & 10,83 \\
\hline
\end{tabular}

*Izračunana so netehtana povprečja.

Prikaz ustaljene podjetniške aktivnosti kaže nekoliko drugačno sliko (tabela 5.2). V Sloveniji se je $\checkmark$ letu pandemije kot najaktivnejša izkazala starostna skupina od 34 do 44 let (njihov delež se je povečal z 22,6 \% v letu 2019 na 36,52 \% v letu 2020). Obe najstarejši starostni skupini sta v primerjavi z letom prej izkazali relativen padec. Leto pandemije je pred podjetnike postavilo zahtevo po čim hitrejši digitalni preobrazbi (Bain, 2020) in nujnem strateškem premisleku o ključnih kompetencah, (re)pozicioniranju na trgu ter uvajanju novih poslovnih modelov (Roland Berger, 2020 v UMAR 2020b), vključno z agilnejšo organizacijo. Ustaljeni slovenski podjetniki v srednjih letih so, kot kaže, najbolje obvladovali te izzive.

Tabela 5.2: Odstotek ustaljenih podjetnikov po starostnih razredih in skupinah držav, GEM Slovenija 2020, APS

\begin{tabular}{|c|c|c|c|c|}
\hline \multirow[b]{2}{*}{$\begin{array}{l}\text { Starost } \\
\text { podjetnikov }\end{array}$} & \multicolumn{4}{|c|}{ Odstotek ustaljenih podjetnikov ${ }^{\star}$} \\
\hline & Slovenija & GEM & $\begin{array}{r}\text { visokodohodkovna } \\
\text { gospodarstva }\end{array}$ & evropske države \\
\hline 18-24 let & 0,00 & 5,88 & 4,67 & 3,70 \\
\hline 25-34 let & 18,70 & 19,25 & 16,78 & 13,94 \\
\hline 35-44 let & 36,52 & 25,91 & 25,03 & 24,22 \\
\hline 45-54 let & 29,39 & 26,92 & 28,52 & 30,92 \\
\hline 55-64 let & 15,39 & 22,30 & 25,31 & 27,63 \\
\hline
\end{tabular}

*Izračunana so netehtana povprečja.

V vseh preostalih treh proučevanih skupinah držav so v letu pandemije največji porast ustaljene podjetniške aktivnosti izkazovali najstarejši ustaljeni podjetniki. Podatek nakazuje na višjo preživetveno moč izkušenih ustaljenih podjetnikov. Ti se ob pojavu pandemije z izrednimi razmerami večinoma niso srečevali prvič v svoji karieri, pač pa so lahko s pridom izkoristili svoje akumulirano znanje, kredibilnost in izkušnje iz preteklih zaostrenih poslovnih situacij.

Motivacija za podjetniško udejstvovanje je kompleksen fenomen. Raziskave kažejo, da je pripravljenost ljudi, da se lotijo izkoriščanja podjetniških priložnosti, odvisna od številnih dejavnikov: njihovih oportunitetnih stroškov (Amit et al., 1995), zalog finančnega kapitala (Evans in Leighton, 1989), povezav z vlagatelji (Aldrich in Zimmer, 1986) in poklicnih izkušenj 
(Cooper et al., 1989). Prav zaradi raznolikosti dejavnikov, ki vplivajo na ustanovitev podjetja, se motivacija za podjetništvo razlikuje tudi med starostnimi skupinami zgodaj podjetniško aktivnih posameznikov. Štiri motive, kot jih proučuje raziskava GEM (ustvariti spremembo v svetu, nadaljevati družinsko podjetje, ustvariti premoženje oziroma višji dohodek in preživeti, saj so službe redke), prikazujemo na sliki 5.2.

Slika 5.2: Zgodnja podjetniška aktivnost po motivih in starostnih razredih

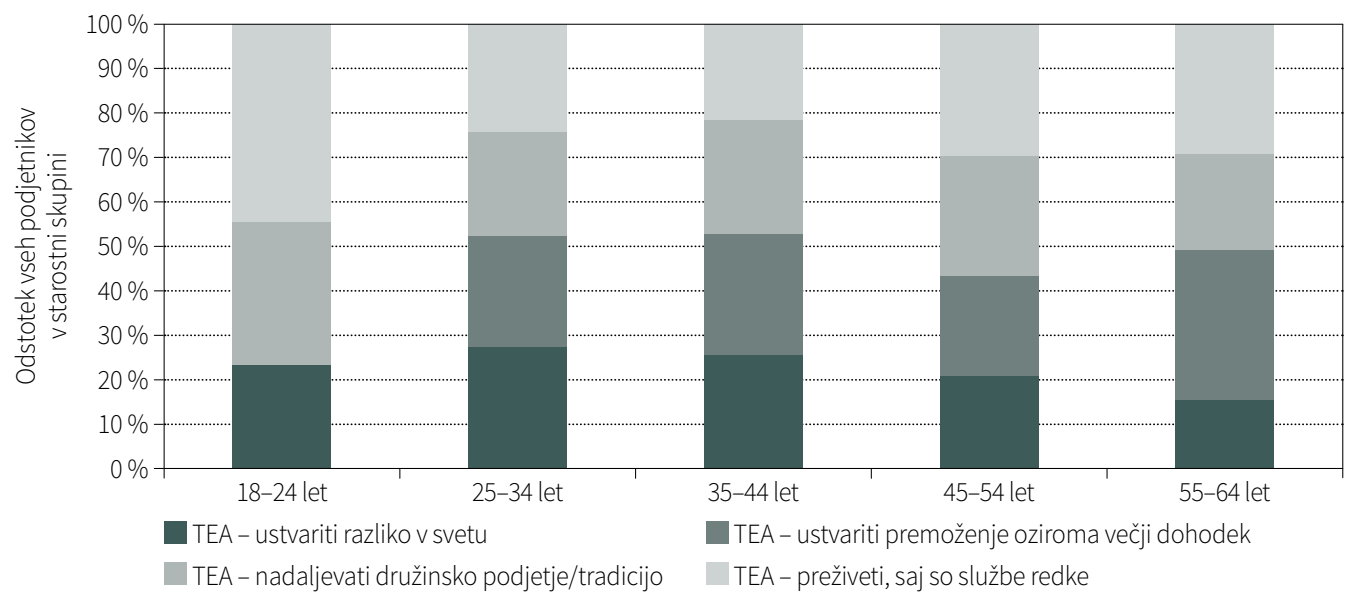

GEM Slovenija 2020, APS

Razlogi za ustanovitev podjetja kažejo na precejšnjo raznolikost motivov med starostnimi skupinami. Preživetveni motiv je najizraziteje prisoten pri najmlajših zgodnjih podjetnikih. To lahko odraža težave pri iskanju primerne službe za tiste z manj izkušnjami. V tej starostni skupini tudi, zanimivo, ne najdemo motiva ustvarjanja premoženja kot enega izmed razlogov za ustanavljanje podjetja. Motiv podjetništva iz nuje se med tistimi v sredini kariere zmanjšujejo, v starostnih skupinah od 45 let naprej pa povečuje, kar verjetno odraža izgubo službe in v družbi prisotno starostno pristranskost. Nadaljevanje družinske tradicije postaja pomembnejše $\vee$ starejših starostnih skupinah, zlasti v starosti od 45 do 54 let. Zgodnje podjetnike v srednjih letih približno uravnoteženo spodbujajo k podjetniškemu udejstvovanje vsi štirje proučevani motivi, čeravno s starostjo narašča težnja po ustvarjanju premoženja oziroma povečevanju dohodka, želja po spreminjanju sveta pa upada.

\subsection{Podjetništvo in mladi}

Brezposelnost mladih je v zadnjih letih znatno upadla. Konec decembra 2019 je bilo registriranih 15.169 brezposelnih mladih, kar je kar 43,7 \% manj kot konec leta 2015 (ZRSZ, 2020d). Epidemija pa je znova poslabšala razmere na trgu dela, še zlasti med mladimi, pri katerih se je stopnja delovne aktivnosti zmanjšala še bistveno bolj kot v starejših starostnih skupinah. Razlog gre iskati v večji razširjenosti začasnih zaposlitev med mladimi v primerjavi z drugimi starostnimi skupinami, kar je vplivalo na njihovo nadpovprečno prizadetost v obdobju začetka epidemije. Dejstvo namreč je, da začasne zaposlitve omogočajo najhitrejši odziv na spremembe $v$ povpraševanju, ki jih delodajalci v primeru zaposlitev za določen čas ne podaljšajo ali pa 
jih - kot v primeru študentskega dela - ob zmanjšanju gospodarske aktivnosti uporabljajo v bistveno manjšem obsegu. V Sloveniji k velikemu deležu mladih z začasno zaposlitvijo prispeva tudi študentsko delo, ki je zelo fleksibilna oblika zaposlovanja mladih. Obseg študentskega dela je bil v Sloveniji v drugem četrtletju 2020 za polovico manjši kot v enakem obdobju 2019 (Kajzer, 2020), zato so bili mnogi mladi prisiljeni razmišljati o alternativnih zaposlitvenih možnostih zgodnja podjetniška aktivnost je ena od njih. Na sliki 5.3 je vidno, da je znašal delež mladih v skupni brezposelnosti konec leta $202021 \%$, kar je največ v zadnjih štirih letih.

\section{Slika 5.3: Število in delež mladih v registrirani brezposelnosti}

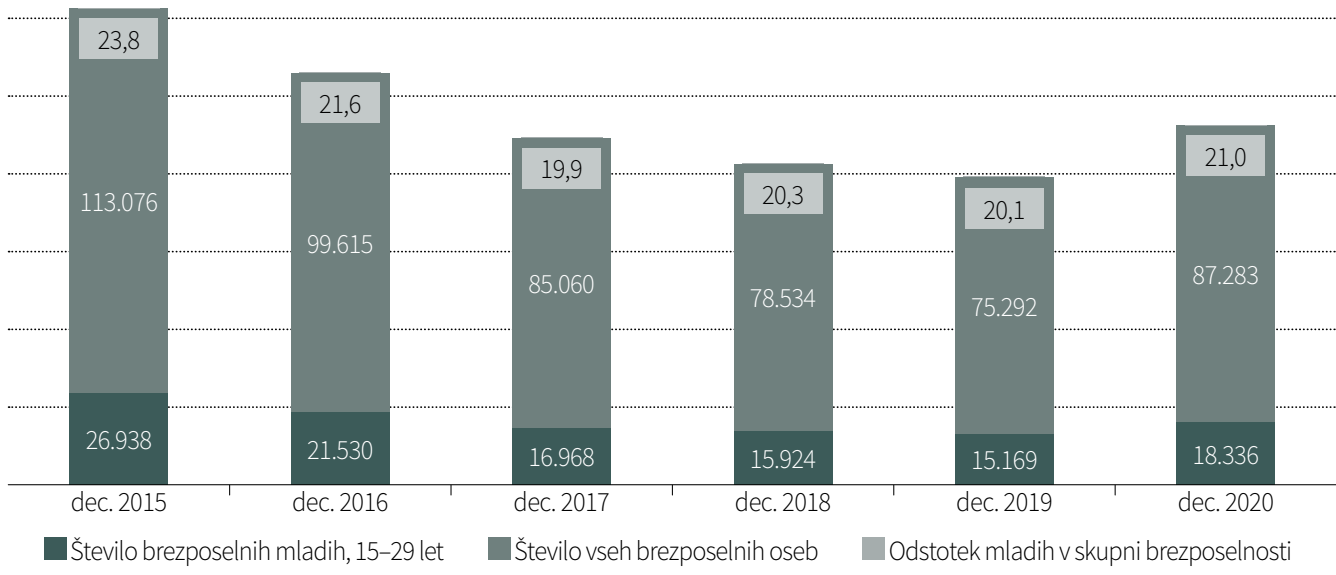

Vir: ZRSZ, 2021

$\checkmark$ nadaljevanju obravnavamo mlade kot posameznike, mlajše od 34 let. Tako pravzaprav $\checkmark$ analizi združujemo obe najmlajši starostni skupini, kot ju proučuje GEM. Na sliki 5.4 je prikazan odstotek zgodnje in ustaljene podjetniške aktivnosti mladih v Sloveniji primerjalno s preostalimi proučevanimi skupinami držav. Če smo uvodoma ugotavljali, da so slovenski zgodnji podjetniki v starosti od 25 do 34 let v letu 2020 izkazovali precej večjo podjetniško angažiranost $\vee$ primerjavi s preostalimi proučevanimi skupinami držav, združitev obeh najmlajših starostnih skupin kaže skupen zaostanek, ki ga je treba pripisati zlasti izredno majhnemu deležu novih podjetij, kijih ustanavlja najmlajša starostna skupina v Sloveniji. Razlog gre najverjetneje iskati v dolžini njihovega izobraževanja. Po podatkih SURS-a se približno 60 \% diplomantov iz leta 2019 do oktobra 2020 še ni pojavila med delovno aktivnimi ljudmi; skoraj $42 \%$ teh je naslednje leto nadaljevalo študij. Med diplomanti iz leta 2018 pa je bilo takih kljub daljšemu obdobju od diplomiranja še približno $48 \%$; skoraj 50 \% teh je naslednje leto nadaljevalo študij (Brnot in Čuk, 2020). Uspešnost mladih pri prvem vključevanju na trg dela oziroma pri iskanju zaposlitve po zaključku šolanja je izrednega pomena za nadaljnji razvoj karierne poti. Z vidika družbe je hitro vključevanje na trg dela pomembno predvsem zato, da se ne izgubi potencial znanja in da se povrne investicija, ki jo država vloži v izobraževanje posameznika, še posebej če je to izobraževanje dolgotrajno (terciarna izobrazba). Daljši čas izobraževanja pomeni več sredstev, ki jih država nameni za izobraževanje posameznika, zato 
je toliko večja izguba potenciala mladih, če se po končanem šolanju v doglednem času ne zaposlijo svoji izobrazbi primerno (ZRSZ, 2020c). Po podatkih SURS-a je do konca oktobra 2020 imelo zaposlitev s polnim delovnim časom kar 90 \% aktivnih diplomantov iz leta 2019. Manj spodbuden je podatek, da jih je več kot 60 \% imelo sklenjeno pogodbo o zaposlitvi za določen čas (Brnot in Čuk, 2020).

Slika 5.4: Odstotek nastajajočih in novih ter ustaljenih podjetnikov, mlajših od 34 let

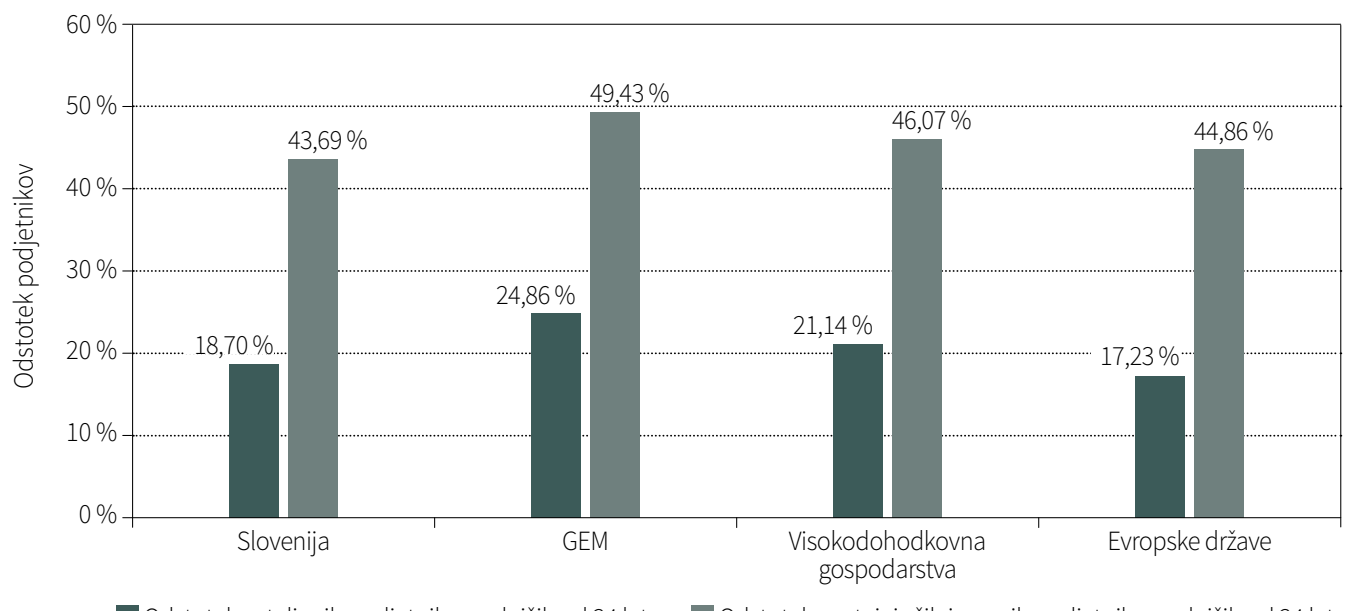

GEM Slovenija 2020, APS

Vpliv epidemije na spreminjanje podjetniške aktivnosti skozi faze življenjskega cikla podjetja je razviden tudi s slike 5.5, na kateri je prikazana petletna dinamika podjetniške aktivnosti mladih. Delež zgodnjih mladih podjetnikov v celotni odrasli populaciji je upadel s 17,4 \% v letu 2019 na 15 \% v letu 2020 zlasti zaradi izrazitega padca deleža nastajajočih podjetnikov. Gre torej za ravno nasproten trend, kot smo mu bili priča leto poprej. Spomnimo: nastajajoči podjetniki začenjajo nov podjem, vendar še niso prešli med lastnike novih podjetij, gre torej za posameznike, ki so začeli ustanavljati podjetje, vendar še ne izplačujejo plač dlje kot tri mesece. Epidemija je torej v veliki meri ustavila podjetniške namere mladih, čemur zagotovo botrujeta padec povpraševanja in velika negotovost v pandemskem letu 2020. Zanimivo je opaziti rahel porast novih mladih podjetnikov v primerjavi z letom 2019 (z 8,3 \% letu 2019 na 9,4\% v letu 2020) in padec ustaljenih podjetnikov med mladimi, kar nakazuje na težavne razmere, ki so jim bila v letu krize izpostavljena številna podjetja, še zlasti tista iz bolj prizadetih dejavnosti, kot so gostinstvo, turizem, promet, trgovina in predelovalne dejavnosti (ZRSZ, 2020a).

Izobrazbena raven zgodnjih podjetnikov v primerjanih starostnih skupinah (od 18 do 34 let in od 35 do 64 let) kaže, da so bili lansko leto mladi nastajajoči in novi podjetniki v povprečju nekoliko višje izobraženi v primerjavi s proučevano skupino odraslih v starosti od 35 do 64 let (slika 5.6). Tudi rezultat deleža samozaposlenih s terciarno izobrazbo je bil v Sloveniji leta 2019 precej nad evropskim povprečjem (49,5 \% v primerjavi s 36,1 \% v EU) (OECD/EU, 2020), kar kaže, da se mladi 
Slovenci pogosto podajajo v podjetništvo visoko izobraženi. Delež samozaposlenih mladih (starih od 20 do 29 let) s terciarno izobrazbo se je v EU med letoma 2002 in 2019 izjemno povečal (s 16,1 \% na 36,1\%). Države članice EU, v katerih je imel največji delež samozaposlenih mladih terciarno izobrazbo, so bile leta 2019 Luksemburg (63,6 \%), Irska (58,8\%), Ciper (57,6 \%), Belgija (56,8 \%), Francija (56,7 \%) in Avstrija (52,0 \%) (OECD/EU, 2019).

Slika 5.5: Podjetniška aktivnost nastajajočih, novih in ustaljenih podjetnikov, mlajših od 34 let

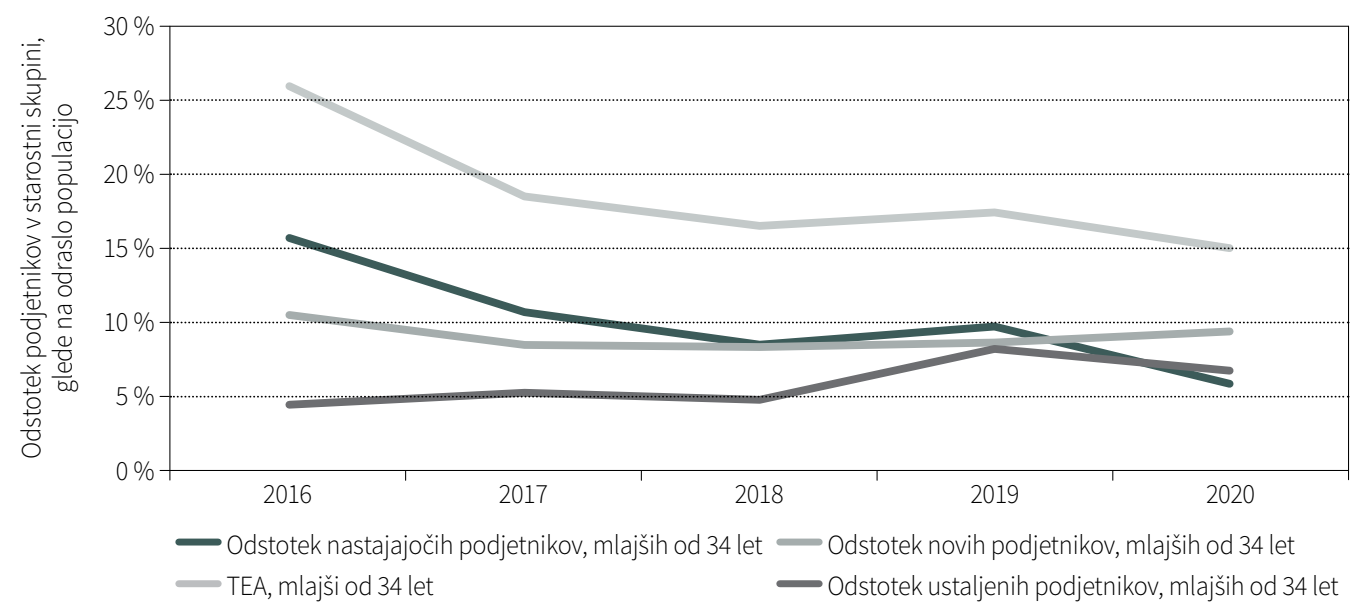

GEM Slovenija 2020, APS

V EU samozaposleni mladi najpogosteje delajo kot strokovnjaki (na primer poslovni in administrativni strokovnjaki, strokovnjaki za IKT), storitveni delavci (na primer storitve osebne nege, trgovine) in $\vee$ osnovnih poklicih (na primer čistilci, pomočniki za pripravo hrane). Na splošno samozaposleni mladi v EU delujejo v manj kapitalsko intenzivnih sektorjih z majhnimi ovirami za vstop na trg. Prav razvoj digitalne ekonomije je povzročil razmah tako imenovanih I-profesionalcev; to so samozaposleni brez zaposlenih, ki se ukvarjajo s kreativno, intelektualno in storitveno usmerjeno industrijo $\mathrm{v}$ visokokvalificiranih poklicih in so praviloma tudi visoko izobraženi (Tominc et al., 2019).

Slika 5.6: Izobrazbena raven nastajajočih in novih podjetnikov po starostnih skupinah od 18 do 34 let in od 35 do 64 let

18-34 let

$41,03 \%$

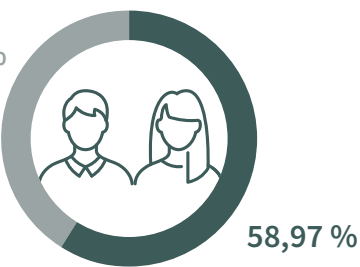

35-64 let

$43,40 \%$

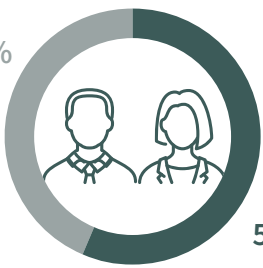

Več kot srednješolska izobrazba

Manj kot srednješolska izobrazba 


\section{$5.3 \mathrm{Spol}$}

Glede na gospodarski in družbeni pomen ženskega podjetništva je razumevanje prispevkov in izzivov, s katerimi se spopadajo ženske, ključnega pomena za splošno poznavanje podjetništva $\checkmark$ nacionalnem gospodarstvu. Čeravno mnogi menijo, da imajo podjetnice in podjetniki enake možnosti, stališča, pristope in dostop do financiranja, $v$ resnici obstajajo razlike, ki so pomembne. Prav boljše razumevanje razlik, ki nastajajo med spoloma v zgodnjih fazah podjetniške aktivnosti, lahko prispeva k boljšemu vpogledu v izobraževanje, politiko in prakso. V nadaljevanju podajamo pregled udeležbe žensk v podjetništvu.

Obstoj vrzeli med spoloma v podjetniški aktivnosti izhaja iz razlik med moškimi in ženskami, ki jo spremlja tudi indeks globalne spolnevrzeli (WEF, 2020). Ta je leta 2020 na svetovni ravni v povprečju znašal 31,4 \%, v Sloveniji pa 25,7 \%, kar uvršča Slovenijo na 36. mesto med 153 proučevanimi državami. Podobno sliko pokaže tudi indeks neenakosti spolov, ki ga meri Razvojni program Združenih narodov in po katerem se Slovenija uvršča na 12. mesto (UNDP, 2019), medtem ko je bila leta 2014 celo prva na svetu. Vrzel med spoloma se odraža tudi v podjetniški aktivnosti moških in žensk v proučevanih državah GEM. V letu 2020 so imeli najvišjo raven participacije žensk v podjetniški aktivnosti Togo (54,37\%), Oman (54,03 \%) in Indonezija (52,25\%), najnižjo pa Italija (23,90 \%) in Egipt (24,54\%). Slovenija se je uvrstila na 30. mesto med 43 proučevanimi državami GEM.

$\checkmark$ nadaljevanju prikazujemo petletni pregled participacije podjetnic v zgodnji (tabela 5.3) in ustaljeni (tabela 5.4) podjetniški aktivnosti primerjalno s proučevanimi skupinami držav (države GEM, visokodohodkovna gospodarstva in evropske države). Zgodnja podjetniška aktivnost žensk se v Sloveniji povečuje že tretje leto zapovrstjo. Od leta 2018 do leta 2020 se je povečala za skoraj 10 odstotnih točk, na 38,3\%, in tako prvič v opazovanem obdobju presegla evropsko povprečje (38,1\%). Ta rezultat je zagotovo presenetljiv, saj kaže, da je padec ekonomske aktivnosti v času pandemije, ki je na trgu dela izraziteje prizadela ženske, posledično prispevala k intenzivnejšemu ustanavljanju podjetij s strani žensk. Podatki o deležu zgodnje podjetniške aktivnosti žensk in moških so za 43 držav GEM prikazani v prilogi 3, v tabeli 3.

Tabela 5.3: Odstotek nastajajočih in novih podjetnic med vsemi podjetniki v obdobju 2016-2020, GEM Slovenija 2020, APS

\begin{tabular}{|l|r|r|r|r|}
\hline $\begin{array}{l}\text { Odstotek } \\
\text { podjetnic }\end{array}$ & Slovenija & GEM & $\begin{array}{r}\text { Visokodohodkovna } \\
\text { gospodarstva }\end{array}$ & Evropske države \\
\hline 2016 & 30,6 & 39,5 & 36,9 & 37,3 \\
\hline 2017 & 30,5 & 40,6 & 37,7 & 38,0 \\
\hline 2018 & 28,9 & 39,9 & 39,2 & 36,7 \\
\hline 2019 & 34,7 & 40,7 & 40,7 & 39,1 \\
\hline 2020 & 38,3 & 41,2 & 40,9 & 38,1 \\
\hline
\end{tabular}

*Izračunana so netehtana povprečja.

Primerjava Slovenije z evropskimi državami GEM (slika 5.7) glede zgodnje podjetniške aktivnosti med spoloma kaže, da se je v letu 2020 Slovenija uvrstila na 9. mesto med 18 proučevanimi državami - lahko bi rekli v zlato sredino - in tako znatno izboljšala svoj položaj na evropski 
lestvici v primerjavi z letom 2019 (ko je zasedla 18. mesto med 21 evropskimi državami). Največjo participacijo žensk v zgodnji podjetniški aktivnosti sta izkazovali Švica $(47,21 \%)$ in Nemčija (46,51 \%), najmanjšo pa Italija (23,97\%) in Luksemburg (31,26 \%).

Slika 5.7: Zgodnja podjetniška aktivnost moških in žensk (v evropskih državah GEM)

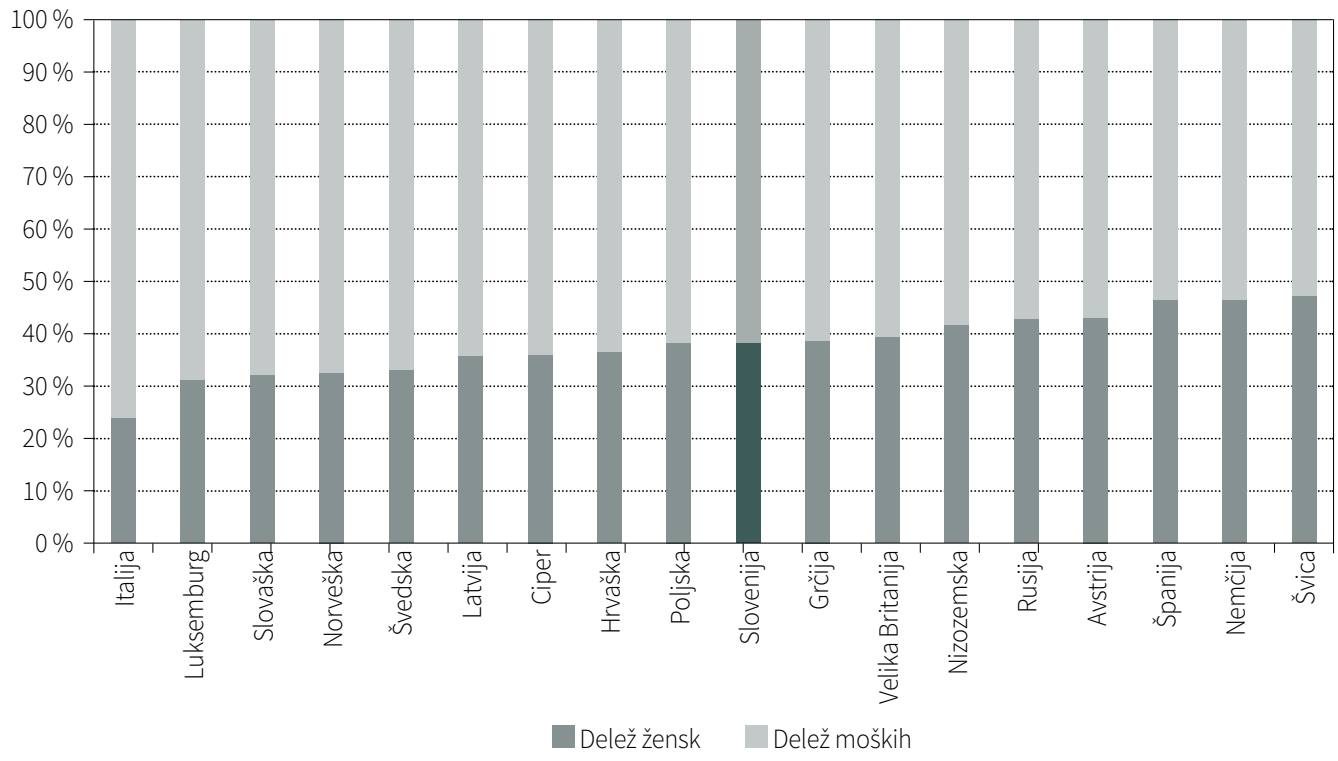

GEM Sloveija 2020,APS

Za ilustracijo prikazujemo $v$ nadaljevanju še primerjalno razmerje med spoloma v zgodnji in ustaljeni podjetniški aktivnosti. Povečanje deleža žensk v zgodnji podjetniški aktivnosti ima za posledico ugodnejše primerjalno razmerje med spoloma. Na vsakih 10 podjetnikov je v Sloveniji 6,21 nastajajoče in nove podjetnice. Povprečje evropskih držav je le nekoliko slabše: na vsakih 10 podjetnikov v Evropi je 6,16 podjetnice (slika 5.8). Manj ugodno je razmerje med slovenskimi ustaljenimi podjetniki, saj je na vsakih 10 ustaljenih podjetnikov le 4,66 podjetnice. Evropsko razmerje med ustaljenimi podjetniki je precej boljše, in sicer je na vsakih 10 podjetnikov 5,10 podjetnice. Največ zgodnje podjetniške aktivnosti žensk v celotni populaciji je med evropskimi državami, enako kot v letu 2019, izkazala Latvija (11,2 \%). 
Slika 5.8: Razmerje v zgodnji in ustaljeni podjetniški aktivnosti med spoloma

\section{Zgodnja podjetniška aktivnost}

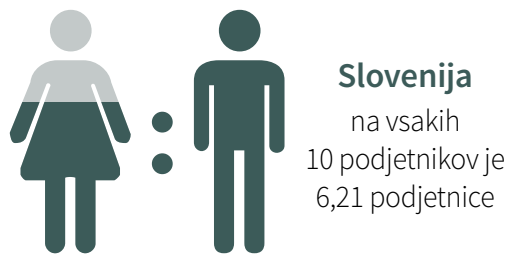

6,21
10

\section{Ustaljena podjetniška aktivnost}

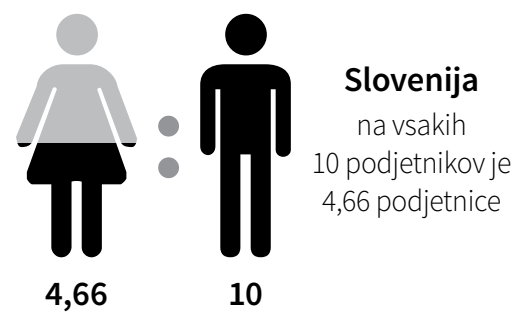

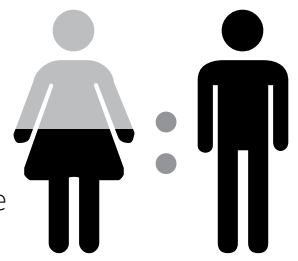

5,10

10

GEM Slovenija 2020, APS

V tabeli 5.4 prikazujemo še odstotek ustaljenih podjetnic med vsemi podjetniki v opazovanem petletnem obdobju. Ustaljena podjetniška aktivnost žensk je tudi v letu 2020 za 2 do 3 odstotne točke zaostajala za povprečjem proučevanih skupin držav. Da je zastopanost ustaljenih podjetnic v celotni populaciji precej neugodno, smo prikazali že na sliki 5.8. Ta podatek je skladen tudi z ugotovitvami raziskave Svetovnega gospodarskega foruma, po katerih so v Sloveniji ženske večinske lastnice le v 13,3\% slovenskih podjetij (WEF, 2020). V letu pandemije so se kot uspešnejša izkazala zlasti podjetja z višjo stopnjo digitalne zrelosti. Podatki raziskave PwC (2018 v UMAR, 2020b) kažejo, da naj bi bile glede na tehnično ogroženost po spolu na srednji rok do konca tega desetletja bolj prizadete ženske, na dolgi rok pa z 49-odstotno ogroženostjo bolj moški (glede na 35-odstotno pri ženskah), kar nakazuje, da lahko v prihodnje zaradi višje stopnje izobraženosti žensk in nižje ravni tehnološke ogroženosti, ki izhaja iz profila dejavnosti, v katerih so aktivne, pričakujemo porast ustaljene podjetniške aktivnosti žensk.

Tabela 5.4: Odstotek ustaljenih podjetnic med vsemi podjetniki v obdobju 2016-2020, GEM Slovenija 2020, APS

\begin{tabular}{|l|r|r|r|r|}
\hline $\begin{array}{l}\text { Odstotek } \\
\text { podjetnic }\end{array}$ & Slovenija & GEM & $\begin{array}{r}\text { Visokodohodkovna } \\
\text { gospodarstva }\end{array}$ & Evropske države \\
\hline $\mathbf{2 0 1 6}$ & 26,1 & 35,2 & 33,3 & 33,5 \\
\hline 2017 & 29,6 & 35,8 & 32,2 & 33,6 \\
\hline 2018 & 33,3 & 36,2 & 35,6 & 36,0 \\
\hline 2019 & 32,2 & 34,6 & 34,3 & 33,9 \\
\hline $\mathbf{2 0 2 0}$ & 31,8 & 34,8 & 34,3 & 33,8 \\
\hline
\end{tabular}


Pregled zgodnje podjetniške aktivnosti glede na starost in spol (slika 5.9) kaže, da je bila pri obeh spolih v letu 2020 najaktivnejša starostna skupina od 25 do 34 let, čeravno so mlade podjetnice izkazovale le pol tolikšno aktivnost kot mladi moški (15,43 \% proti 7,58 \%). Najpogosteje navajani razlogi za ustanavljanje podjetij s strani žensk so želja po neodvisnosti, uresničevanje svoje poslovne strasti in nezadovoljstvo z delovnim položajem v podjetju. Hkrati ženske pogosteje kot moški iščejo prožnost, samostojnost in možnost za nadziranje lastnega urnika, kar jim omogoča doseganje boljšega ravnovesja med delom in družinskimi obveznostmi. Končno bi lahko kot katalizator podjetniške aktivnosti v starostni skupini mladih navedli tudi razpoložljivost/ dostopnost finančnih virov in podporo usposabljanju, ki so na voljo prek subjektov inovativnega okolja in drugih programov. Vrzel med spoloma se z leti zmanjšuje. V pandemskem letu preseneča podatek, da so ženske $v$ kar dveh starostnih skupinah presegle raven zgodnje podjetniške aktivnosti moških, in sicer v najmlajši in najstarejši starostni skupini, kjer je sicer vrzel med spoloma $\checkmark$ relativnem smislu tudi največja.

\section{Slika 5.9: Podjetniška aktivnost v Sloveniji glede na starost in spol}

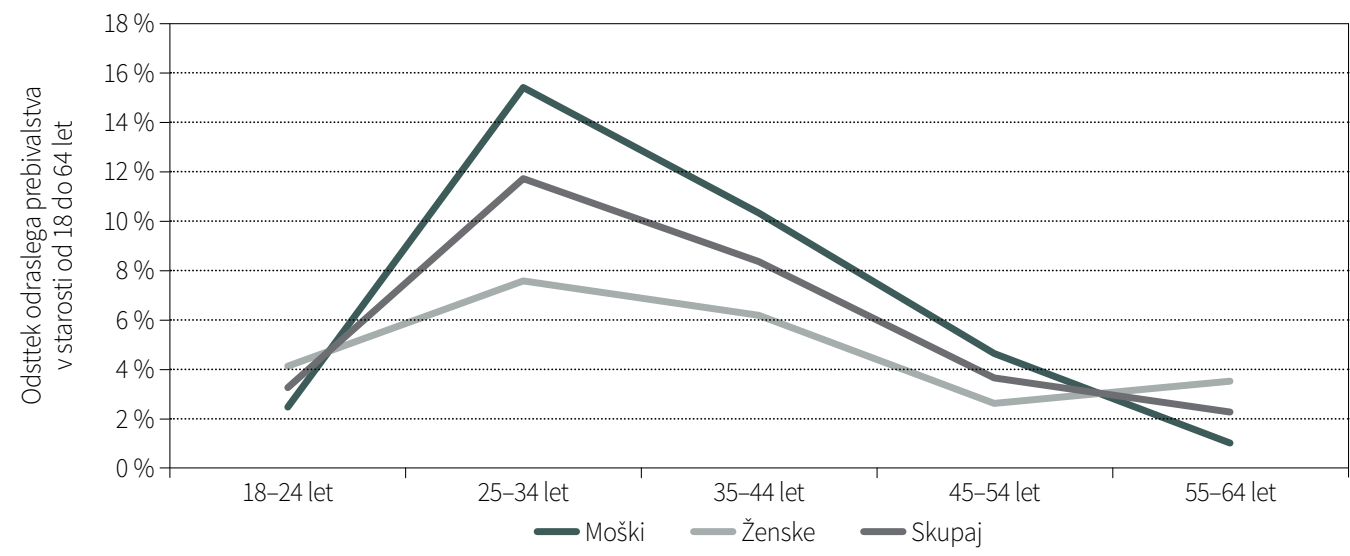

GEM Slovenija 2020, APS

Podjetja, ki jih vodijo ženske, se v marsičem razlikujejo od tistih, ki jih vodijo moški. Nekatere raziskave kažejo, da so ženske manj nagnjene k rasti svojih podjetij (Delmar in Holmquist, 2004). Spet druge, novejše raziskave pa dvomijo o tem dolgoletnem prepričanju. Raziskava Saridakisa in soavtorjev (2014) dokazuje, da na namere žensk po rasti enako verjetno kot na namere moških vplivajo ekonomski vidiki (stanje gospodarstva, dostop do financiranja) in socialni dejavniki (zakonski dejavniki in obveznosti, povezane z družino). Drugi ključni dejavnik pri razlagi razlik med spoloma je socialni in institucionalni kontekst. Paradoksalno je, da je enakost spolov na nacionalni ravni negativno povezana z izbiro samozaposlitve žensk v primerjavi z moškimi (Klyver et al., 2013), kar kaže na to, da lahko politike enakosti spolov na trgu dela prispevajo k temu, da se ženske pogosteje zaposlujejo kot samozaposlujejo (Nielsen et al., 2010).

Dodaten vpogled $v$ kakovost zgodnje podjetniške aktivnosti nam daje primerjava motivov (slika 5.10), zaradi katerih ženske in moški ustanavljajo podjetja. V letu epidemije je bil najpogosteje izražen motiv potrebe po preživetju, kar velja za oba spola in tako za Slovenijo kot za povprečje Evrope. Ženske manj pogosto kot moški prevzemajo družinska podjetja. Medtem ko je po 
pogostosti pri slovenskih moških na drugem mestu želja po ustvarjanju sprememb v svetu, je drugi najpogosteje izražen motiv slovenskih podjetnic želja po ustvarjanju premoženja oziroma dvigu dohodka. Ta motiv je v povprečju bolj izražen tudi pri moških v proučevanih evropskih državah. Sklenemo lahko, da je v bil v letu pandemije najpogostejši motiv za ustanavljanje podjetij pri obeh spolih motiv nujnosti oziroma podajanje v podjetništvo zaradi potrebe po preživetju.

\section{Slika 5.10: Zgodnja podjetniška aktivnost po motivih in spolu}

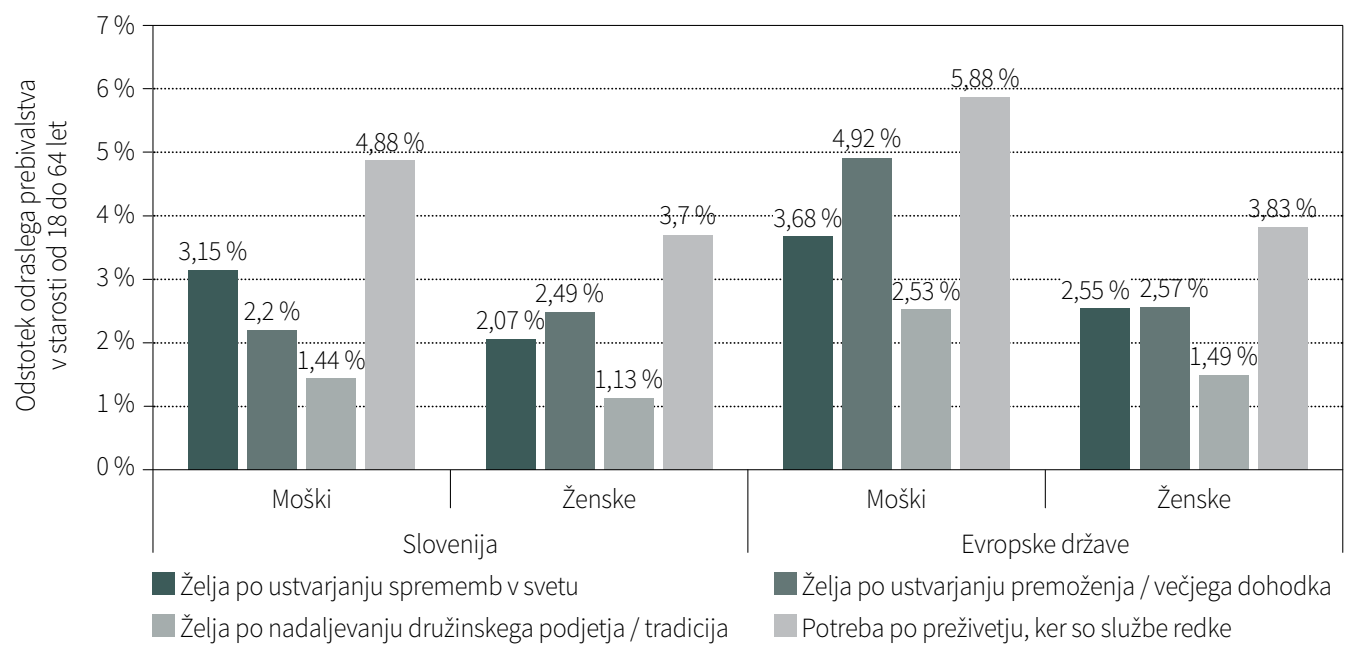

GEM Slovenija 2020, APS

\subsection{Izobrazba}

Podjetniško izobraževanje na ravni posameznika krepi poklicne ambicije, vodi kvečji zaposljivosti, izboljšuje podjetniške veščine in podjetniški odnos ter privede do vedenjskih sprememb v smislu več podjetniških namer (Curth et al., 2015). Na drugi strani na ravni institucij velja, da univerze, ki izvajajo podjetniško izobraževanje, razvijejo močnejšo podjetniško kulturo, predavatelji postanejo bolj angažirani, ob navedenem pa se okrepi tudi sodelovanje zunanjih deležnikov z univerzo (lokalna skupnost, lokalno gospodarstvo, politika ipd.). Avtorji gredo še dlje in navajajo, da ima podjetniško izobraževanje vpliv na celotno družbo, saj predstavlja tisti element, ki lahko pomaga zaščititi posameznika pred socialno izključenostjo.

Že več let ugotavljamo, da se izobrazbena struktura prebivalcev Slovenije ob veliki vključenosti mladih v srednješolsko in terciarno izobraževanje ter prehajanju mladih v višje starostne skupine (demografski učinek) že vrsto let izboljšuje. Spretnosti odraslih pa še naprej ostajajo slabše (UMAR, 2020b) in posledično tudi njihova usposobljenost za podjetniško udejstvovanje. Dejstvo je, da podjetniško izobraževanje ni namenjeno zgolj ustanavljanju ambicioznih podjetij, pač pa bi večina mladih, ki bi šli skozi izobraževanje za podjetnost in podjetništvo, lahko uporabila pridobljena znanja in spretnosti v številnih poklicih in organizacijah ter dvignila raven znanja in inovacij v podjetjih. To je razlog, zaradi katerega bi izobraževanje za podjetnost in podjetništvo moralo biti na voljo vsem študentom v visokošolskem izobraževanju (Rae et al. 2011). 
Slika 5.11: Izobrazba nastajajočih, novih in ustaljenih podjetnikov in nepodjetnikov

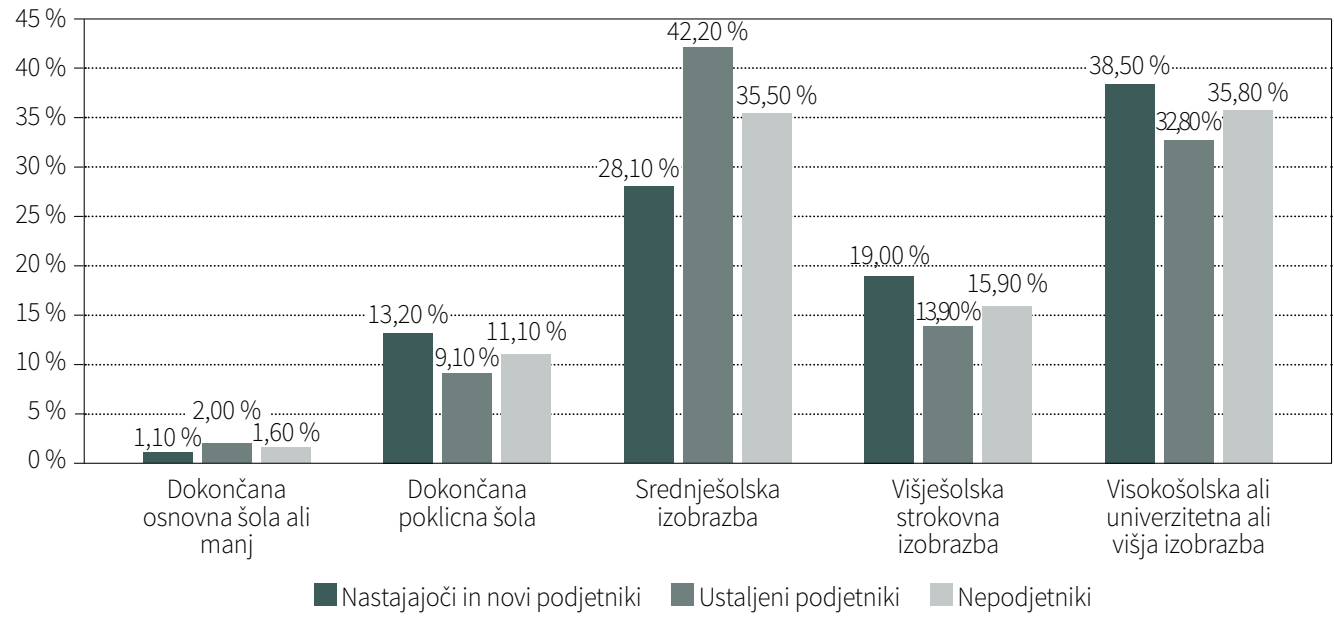

GEM Slovenija 2020,APS

Na sliki 5.11 prikazujemo izobrazbeno strukturo zgodnjih in ustaljenih podjetnikov in nepodjetnikov za leto 2020. Med nastajajočimi in novimi podjetniki je bilo največ takšnih z visokošolsko, univerzitetno ali višjo izobrazbo (38,5\%). Ustaljeni podjetniki imajo prevladujočo srednješolsko izobrazbo (42,2\%), med nepodjetniki pa izkazujeta skoraj enak delež srednješolska (35,5\%) in visokošolska, univerzitetna ali višja izobrazba (35,8\%). Večkrat omenjena potreba po digitalnih veščinah, ki so zagotovo prispevale k izrabi poslovnih priložnosti v letu pandemije, kaže na potrebo po prilagajanju razvoja znanj in spretnosti v prihodnjih letih. Prav zato je na področju visokega šolstva prioriteta povečati število vpisnih mest na študijskih programih, pomembnih za digitalno preobrazbo, in krepiti povezovanje med visokim šolstvom in podjetji. Na področju vseživljenjskega učenja pa mora država spodbuditi vključenost odraslih v vseživljenjsko učenje, razvijati programe prekvalifikacij in spodbujati vključevanje vanje, da bi se izboljšala digitalna pismenost odraslih (UMAR, 2020b).

\subsection{Dohodek}

Neenakost najpogosteje merimo z dohodkovno neenakostjo. Dohodek večinoma merimo z razpoložljivimi viri dohodkov gospodinjstva: plača, kapital, viri gospodinjstva, progresivni davki in transferji (Bonesmo Fredriksen, 2012). Razloge za povečevanje dohodkovne neenakosti pripisujemo spremembam $v$ tehnologiji (večanje produktivnosti bolj izobraženih oseb in s tem njihovih plač), selitvi proizvodnje v države z nižjimi stroški dela (nižanje plač manj izobraženih) in zmanjšanju moči sindikatov (Eurofound, 2017). Drugi razlog izhaja iz razpršenosti ur dela (posledica zaposlitev za krajši čas in za določen čas), kar lahko povežemo s fleksibilizacijo dela in nestandardnimi oblikami dela (Rihter in Leskošek, 2020). Raziskava GEM spremlja zgodnjo in ustaljeno podjetniško aktivnost z vidika razpoložljivosti dohodka $v$ treh dohodkovnih razredih (spodnja, srednja in zgornja tretjina). Primerjava dohodkovnih ravni za skupine nastajajočih, novih in ustaljenih podjetnikov za leto 2019 in 2020 je prikazana na sliki 5.12. 
Slika 5.12: Dohodkovni razredi v celotnem podjetniškem procesu

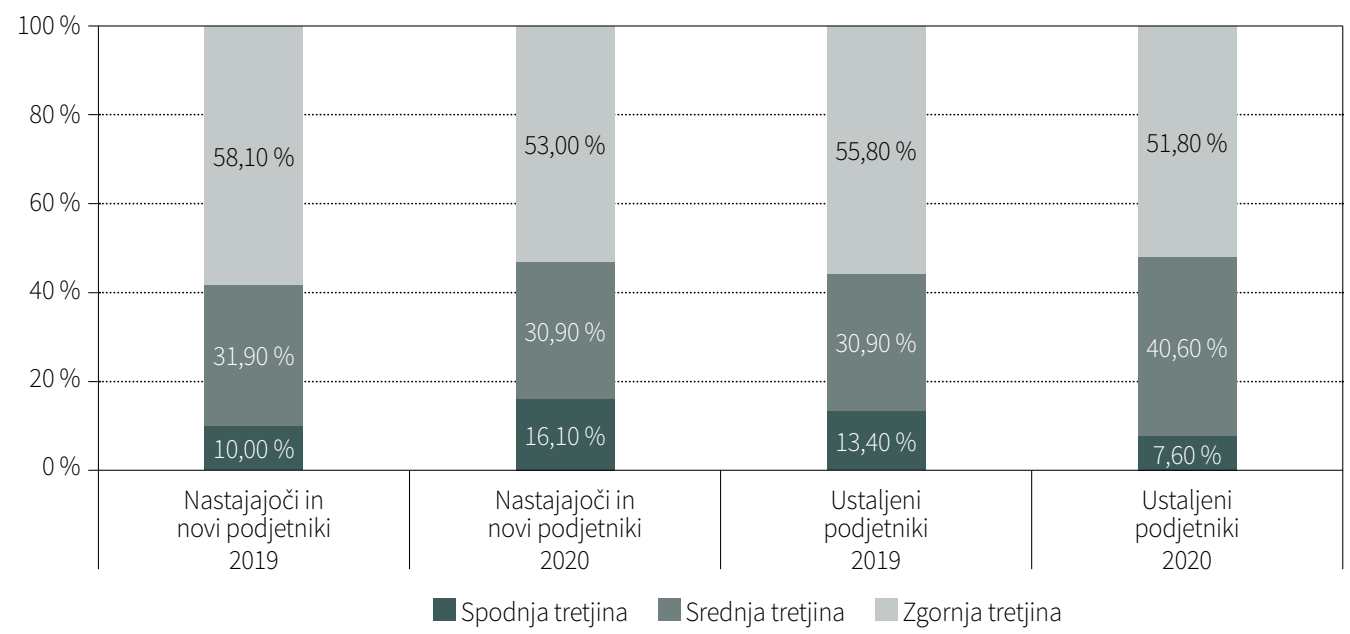

GEM Slovenija 2020, APS

Med nastajajočimi in novimi podjetniki se jeza več kot 6 odstotnih točk povečal deležustanoviteljev podjetij z najnižje dohodkovne ravni. Podatek je skladen z najpogosteje ugotovljenim motivom za zgodnjo podjetniško aktivnost med Slovenci, ki je bil v letu 2020 pretežno preživetveni motiv, in tudi z odgovori slovenskih podjetnikov, ki so v 44,7 \% primerih v letu krize zaradi covida-19 navajali padec družinskih dohodkov. Med ustaljenimi podjetniki se je v največji meri povečal delež tistih s srednje dohodkovne ravni (s 30,9\% v letu 2019 na 40,6 \% v letu 2020). K tej spremembi je po eni strani prispeval padec gospodarske aktivnosti in zaslužka med najbogatejšimi, na drugi strani pa slabša izraba potenciala obetavnih priložnosti med najrevnejšimi ustaljenimi podjetniki, ki so v manjši meri izkoristili krizne razmere v svoj prid. Pandemsko leto je še dodatno izpostavilo potrebo po digitalni preobrazbi, ki bo imela znaten vpliv - na primer preko ustvarjenih dohodkov - tudi na podjetnike. Negativen pritisk naj bi bil pri tem večji pri tistih z nižjimi dohodki (OECD, 2017b), kar naj bi ustvarjalo dodaten pritisk na družbeno kohezijo oziroma na povečano družbeno polarizacijo (UMAR, 2020b). 



\section{Podjetniške aspiracije}

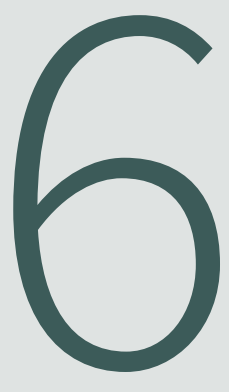

\section{Ključna spoznanja}

- V letu 2020 smo v okviru raziskave GEM izmerili, da je bilo v Sloveniji zelo ambicioznih nastajajočih in novih podjetnikov $17 \%$, kar je povečanje za dve odstotni točki glede na predhodno leto. Ta rezultat kljub izraziti rastiv zadnjih dveh letih še vedno negativno odstopa od ambicioznosti podjetnikov v skupini držav z visokodohodkovnim gospodarstvom, smo se pa že postavili ob bok skupini evropskih držav.

- V Sloveniji so se pričakovanja o zagotavljanju več kot petih delovnih mest v zadnjem letu povečala za okrog 7 odstotnih točk, v drugih skupinah držav pa so ostala enaka ali pa so se zmanjšala. Ta rezultat mogoče malo preseneča glede na nastop krize zaradi covida-19 v letu 2020, vendar je pri tem treba upoštevati, da se podatki za Slovenijo nanašajo na prvi val epidemije, večina drugih držav pa je anketiranje izvedla nekoliko kasneje v letu.

- V Sloveniji imamo velik delež podjetij, ki niso zaposlovalci in tudi ne načrtujejo postati dejanski zaposlovalci. Medtem ko v Sloveniji ustvarja ali načrtuje ustvariti delovna mesta 4,95 \% podjetnikov, je ta delež v državah GEM 11,50 \%, v državah z visokodohodkovnim gospodarstvom 9,98 \% in v evropskih državah 5,79 \%. To verjetno pojasnjuje tudi zaznano večje število zaprtih podjetij v času pandemije v letu 2020, saj je podjetja z nič zaposlenimi bistveno laže zapreti kot podjetja z zaposlenimi. 


\subsection{Ambicioznost podjetnikov}

V družbi se vse bolj krepi zavedanje o pomenu inovativnih podjetij in ambicioznih podjetnikov, ki jih ustvarjajo in vodijo. Inovativna in hitro rastoča podjetja, usmerjena v mednarodni prostor, namreč ustvarjajo nadpovprečno dodatno vrednost in največ novih delovnih mest (Autio in Acs, 2010; Bowen in De Clercq, 2008; Wennekers et al., 2010; Estrin, Korosteleva in Mickiewicz, 2014). Kot navaja Fuentelsaz s sodelavci (2020), pa lahko ta potencialna nova delovna mesta neposredno povežemo z ekonomsko rastjo in razvojem (Autio in Acs, 2010), ki nadalje dviguje družbeno zavedanje o pomenu hitro rastočih inovativnih podjetij in jih vse bolj postavlja kot prioriteto $\mathrm{v}$ ekonomski politiki držav.

Ker sta ustanavljanje in še posebej uspešna rast takšnih podjetij zelo zahtevna in povezana z velikimi tveganji, so taka podjetja žal zelo redka. Vsi načrti podjetnikov za rast se ne realizirajo vedno tako, kot je želeno, saj podjetnikom ne uspe zagotoviti vseh ustreznih virov, ne dobijo pozitivnega odziva na trgu ali pa naletijo na druge ovire $\vee$ poslovnem okolju, $v$ katerem delujejo (Carlsson-Wall et al., 2012). V Veliki Britaniji je na primer v populaciji preživelih novih podjetij delež hitro rastočih podjetij, ki zaposlujejo 10 in več ljudi, znašal skromnih 6,4%, pri čemer so ta podjetja ustvarila kar $64 \%$ vseh novih delovnih mest (Bravo-Biosca et al., 2013).

Namere podjetnika po rasti podjetja so rezultat njegove zavestne in načrtovane aktivnosti, kar so že pred časom potrdile številne empirične študije, ki kažejo na povezavo med ravnijo podjetniških ambicij podjetnikov in rastjo njihovih podjetij (Kolvereid in Bullvag, 1996; Baum, Locke in Kirkpatrick, 1998; Baum, Locke in Smith, 2001; Wiklund in Shepherd, 2003; Delmar in Wiklund, 2008). Za trajnostni uspeh in rast podjetja je namreč pomembno, da je podjetje že v zgodnjih fazah usmerjeno v mednarodno okolje, pri čemer razvija in trži mednarodno konkurenčne izdelke ali storitve in išče kupce v mednarodnem okolju, podjetnik pa ima ambiciozne načrte in pričakovanja o obsegu poslovanja in zaposlovanja (Zieba, 2017).

Se pa z rastjo podjetja raven aspiracij podjetnikov znižuje, saj so bile izmerjene aspiracije po rasti nastajajočih podjetnikov v raziskavi Bagerja in Schotta (2004) značilno večje od aspiracij po rasti že uveljavljenih podjetnikov. Raziskovalci še iščejo prave razloge, pri čemer vidijo potencialna pojasnila v naravni selekciji podjetnikov, saj trg najprej izloči tiste z največjimi aspiracijami po rasti, ki morajo za svoj uspeh pritegniti večjo količino resursov in tudi bolj specifične, kar je težje in bolj tvegano (Zieba, 2017).

$\checkmark$ raziskavi GEM želimo meriti in bolje razumeti raven aspiracij podjetnikov po rasti $\vee$ zgodnji podjetniški aktivnosti in jih primerjati z drugimi poslovnimi okolji ter na ta način iskati vire in vzvode izboljšav. Raven aspiracij podjetnikov po rasti merimo s pomočjo njihovih subjektivnih ocen o tem, koliko dodatnih delovnih mest bo njihovo podjetje zagotovilo v naslednjih petih letih. S svojimi raziskovalnimi rezultati želimo pomagati oblikovalcem vladnih politik in ukrepov, ki spodbujajo te namere oziroma olajšujejo njihovo udejanjanje v praksi.

$\vee$ tabeli 6.1 so prikazani deleži najambicioznejših podjetnikov $\vee$ Sloveniji in $\vee$ proučevanih skupinah držav. Ambicioznost slovenskih nastajajočih in novih podjetnikov negativno odstopa od pričakovanj kolegov iz preostalih skupin držav. Podjetniki iz skupine držav z visokodohodkovnim gospodarstvom izkazujejo precej višjo stopnjo ambicioznosti, saj je znotraj TEA dobrih $21 \%$ takšnih, ki pričakujejo, da bo njihovo podjetje ustvarilo 10 ali več delovnih mest v petih letih od zagona podjetja (v Sloveniji je ta delež leta 2020 znašal slabih 17 \%, leta 2019 pa slabih 15 \%). 
Tabela 6.1: Ambicioznost podjetnikov po skupinah držav, GEM Slovenija 2020, APS
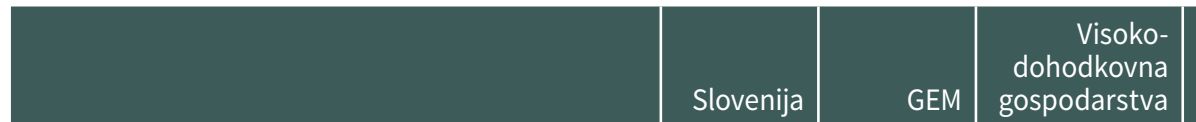

Evropske

Delež podjetnikov v TEA, ki pričakujejo, da bo njihovo podjetje ustvarilo 10 ali več delovnih mest v petih letih od zagona podjetja*

$16,79 \%$

$19,89 \%$

$21,33 \%$

$16,14 \%$

Delež podjetnikov v celotni populaciji, ki pričakujejo, da bodo ustvarili 19 ali več delovnih mest v petih letih od zagona podjetja*

$0,60 \% \quad 1,93 \%$

$2,03 \%$

$0,87 \%$

*Aliv petih letih od tega trenutka, če podjetje že posluje, pri čemer se dodatno zahteva, da znaša rast števila delovnih mest vsaj $50 \%$.

**Aliv petih letih od tega trenutka, če podjetje že posluje.

Še večje relativne razlike med Slovenijo in proučevanimi skupinami držav po ambicioznosti podjetnikov zasledimo pri še bolj ambiciozno zastavljenem cilju, da bi ustvarili 19 ali več novih delovnih mest $v$ petih letih. Če je $v$ Sloveniji 0,60\% anketirancev na ravni celotne populacije prepričanih, da lahko v petih letih ustvarijo 19 ali več delovnih mest, je ta delež v državah GEM in visokodohodkovnih gospodarstvih več kot trikrat večji. V primerjavi s skupino evropskih držav (0,87\%) je zaostanek precej manjši.

Dobrih $25 \%$ evropskih nastajajočih in novih podjetnikov pričakuje, da bodo čez pet let ustvarili več kot pet delovnih mest (glej sliko 6.1), pri čemer je bil v Sloveniji ta delež s 30 \% nekoliko večji. S tem rezultatom se je Slovenija uvrstila v srednje ambiciozno skupino evropskih držav, vključenih $\checkmark$ raziskavo GEM. Največji delež ambicioznih podjetnikov med evropskimi državami so leta 2020 izkazovali Rusija (50\%), Ciper (45\%), Luksemburg (38\%), Norveška in Latvija (32\%). Najmanj ambicioznosti glede števila zaposlenih čez pet let pa so v skupini evropskih držav izražali nastajajoči in novi podjetniki v Avstriji (3 \%), Švici (12 \%), Španiji (14 \%), na Nizozemskem (15\%) in v Grčiji (17 \%).

Slika 6.1: Pričakovanja podjetnikov, da $v$ petih letih ustvarijo več kot pet delovnih mest, $v$ TEA (v evropskih državah GEM)

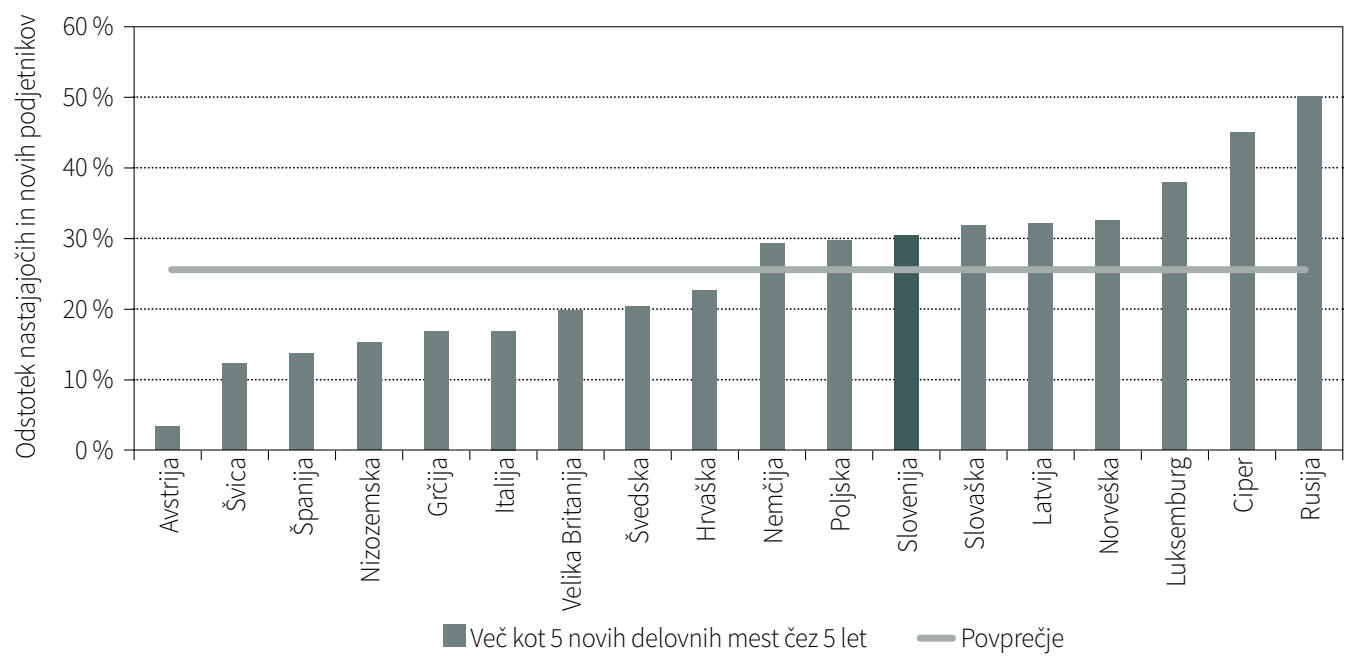


V Sloveniji lahko v zadnjih letih zaznavamo postopno izboljševanje ambicioznosti podjetnikov, ki se je v zadnjem letu ponovno okrepila za 7 odstotnih točk. Sicer je delež ambicioznih podjetnikov leta 2019 znašal 23 \%, leta 2018 19 \%, leta 201722 \%, leta 201633 \%, leta 201524 \%, leta $201429 \%$ in leta $201335 \%$.

Če Slovenijo primerjamo s posameznimi skupinami držav, kar prikazujemo na sliki 6.2, so se razlike $\checkmark$ pričakovanjih podjetnikov po več kot petih delovnih mestih $v$ njihovem podjetju čez pet let $v$ zadnjem letu močno zmanjšale. Po eni strani so se v Sloveniji pričakovanja povečala za okrog 7 odstotnih točk, v drugih skupinah držav pa so ostala enaka (v državah GEM 32 \%) oziroma so se zmanjšala (v skupini držav z visokodohodkovnim gospodarstvom s 34 \% leta 2019 na 32 \% leta 2020 in v evropskih državah s $30 \%$ na $26 \%$ ). Ta rezultat mogoče malo preseneča glede na nastop krize zaradi covida-19 v letu 2020, je pa pri tem treba upoštevati, da se podatki za Slovenijo nanašajo na prvi val epidemije, večina drugih držav pa je anketiranje izvedla nekoliko kasneje v letu. Predvidevamo, da bi bila slika ob anketiranju po nadaljevanju pandemije jeseni drugačna.

Slika 6.2: Načrti podjetnikov o zaposlovanju po skupinah držav

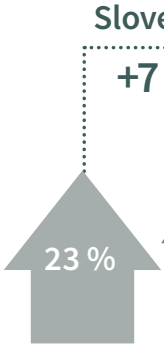

2019

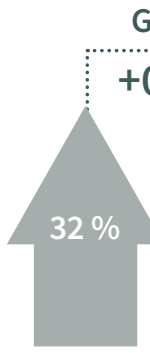

2019
GEM

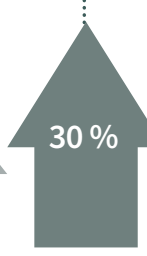

2020
$+0 \%$

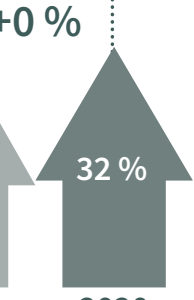

2020
Visokodohodkovna gospodarstva

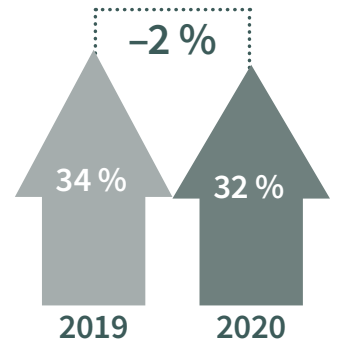

Evropske države

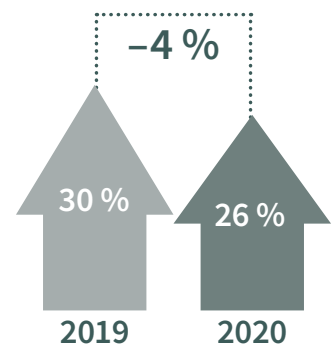

GEM Slovenija 2020, APS

Večje razlike lahko zaznamo tudi na ravni vseh anketirancev (od 18 do 64 let), vključenih $\vee$ TEA (glej tabelo 6.2). V Sloveniji je leta 2020 4,95\% (5,77\% v letu 2019) oseb poročalo, da že ustvarjajo delovna mesta oziroma jih bodo vsaj $\vee$ naslednjih petih letih od zagona podjetja (ali v petih letih od tega trenutka, če podjetje že posluje) in bodo tako postali »podjetje zaposlovalec«. Tudi pri tej spremenljivki je delež slovenskih podjetnikov manjši v primerjavi z deležem v drugih skupinah držav (države GEM 11,50 \%, visokodohodkovna gospodarstva 9,98 \% in evropske države 5,79 \%), kar tudi pomeni, da je v Sloveniji večji delež podjetnikov takšnih, da niso zaposlovalci in tudi ne načrtujejo postati dejanski zaposlovalci. To mogoče pojasnjuje tudi zaznano večje število zaprtih podjetij včasu pandemije letu 2020, saj je podjetje z nič zaposlenimi bistveno laže zapreti kot podjetje z zaposlenimi. 
Tabela 6.2: Načrti podjetnikov o zaposlovanju po skupinah držav, GEM Slovenija 2020, APS

\begin{tabular}{|c|c|c|c|c|}
\hline & Slovenija & GEM & $\begin{array}{r}\text { Visokodohodkovna } \\
\text { gospodarstva }\end{array}$ & $\begin{array}{r}\text { Evropske } \\
\text { države }\end{array}$ \\
\hline $\begin{array}{l}\text { Delež podjetnikov v TEA, ki pričakujejo, da } \\
\text { bo v njihovem podjetju čez pet let več kot pet } \\
\text { delovnih mest }\end{array}$ & $30,41 \%$ & $31,52 \%$ & $32,34 \%$ & $25,55 \%$ \\
\hline $\begin{array}{l}\text { Delež podjetnikov v celotni populaciji, ki že } \\
\text { ustvarjajo delovna mesta oziroma jih bodo vsaj } \\
\text { v naslednjih petih letih od zagona podjetja }\end{array}$ & $4,95 \%$ & $11,50 \%$ & $9,98 \%$ & $5,79 \%$ \\
\hline
\end{tabular}

Na sliki 6.3 so prikazana pričakovanja odraslega prebivalstva v evropskih državah, vključenih v raziskavo GEM, glede dejstva, ali s svojo poslovno dejavnostjo že ustvarjajo delovna mesta oziroma ali pričakujejo, da bodo v naslednjih petih letih ustvarili vsaj eno delovno mesto. Delež takšnih odraslih prebivalcev je v Sloveniji leta 2020 znašal 4,95 \%, s čimer smo se uvrstili pod povprečje evropskih držav, vključenih v raziskavo GEM. Največji delež odraslih prebivalcev, ki že ustvarjajo delovna mesta ali verjamejo, da jih bodo ustvarjali v naslednjih petih letih, je v Latviji (11,75\%), na Slovaškem (9,39 \%), Hrvaškem (8,3\%) in na Cipru (8,09\%), najmanjši delež pa v Italiji (1,17 \%).

Slika 6.3: Podjetniki, ki že zaposlujejo oziroma to načrtujejo, v celotni populaciji (v evropskih državah GEM)

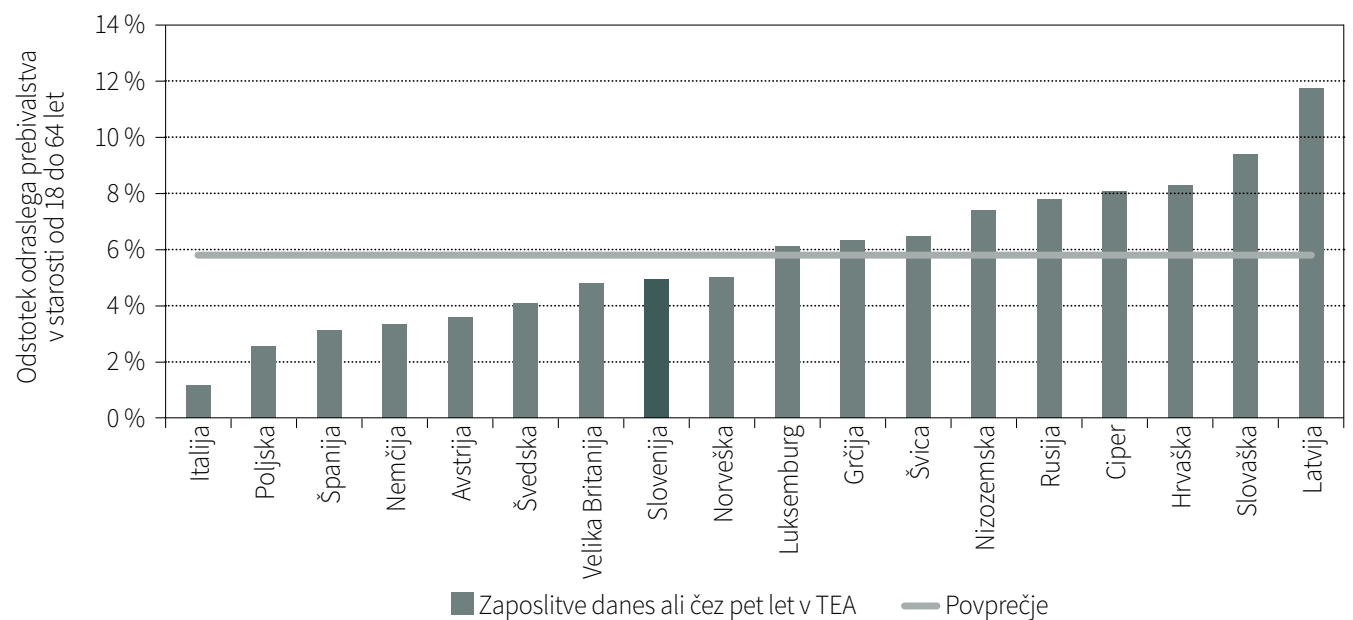

\subsection{Usmerjenost v mednarodni prostor}

Podjetniške rasti praviloma ni mogoče dosegati na majhnem lokalnem ali nacionalnem tržišču. Za podjetje, locirano v Sloveniji, je zato skorajda nujno, da je usmerjeno v mednarodni prostor, to pa je povezano, kot navaja Estrin s sodelavci (2014), s številnimi tveganji, vendar istočasno ustvarja tudi dodatni potencial za rast. 
V raziskavi GEM smo tudi v letu 2020 uporabili raziskovalna vprašanja, ki smo jih redefinirali leta 2019 in s katerimi proučujemo stopnjo mednarodnosti poslovanja podjetij ter stopnjo njihove inovativnosti in konkurenčnosti. Vprašanja so namenjena raziskovanju razpona delovanja nastajajočih in novih podjetij, in sicer v naslednjih elementih:

- razpon ciljnega trga, ki ga definira geografski izvor kupcev, namreč, ali prihajajo iz lokalnega, nacionalnega ali globalnega okolja,

- razpon novosti novih izdelkov in storitev, in sicer, ali so novi za kupce na lokalni, nacionalni ali globalni ravni,

- razpon novosti tehnologij in procesov podjetja, in sicer, ali so novi na lokalni, nacionalni ali globalni ravni.

Če Slovenijo primerjamo s posameznimi skupinami držav, in sicer glede na to, ali podjetja svoje izdelke in storitve tržijo le v lokalnem ali tudi v nacionalnem ali celo mednarodnem okolju, so slovenska nastajajoča in nova podjetja nadpovprečno osredotočena na kupce $\vee$ globalnem okolju. Kot je prikazano na sliki 6.4, slaba polovica slovenskih podjetnikov poroča, da imajo kupce tudi na globalni ravni (46\% podjetij), pri čemer je v drugih skupinah držav ta delež precej manjši: v državah GEM 23 \%, v skupini visokodohodkovnih gospodarstev 29 \% in v evropskih državah 33 \%.

Ti rezultati ne presenečajo, saj so slovenski podjetniki že tradicionalno zelo mednarodno usmerjeni, kar kažejo tudi rezultati predhodnih raziskav. K temu jih sili majhnost slovenskega trga, ki je še posebej omejujoča na zelo nišnih trgih. Določena inovacijsko gnana slovenska podjetja tako na slovenskem trgu sploh ne ustvarjajo omembe vrednega obsega poslovanja, ampak so skoraj v celoti usmerjena na mednarodne trge.

Slika 6.4: Geografski izvor kupcev podjetij po skupinah držav

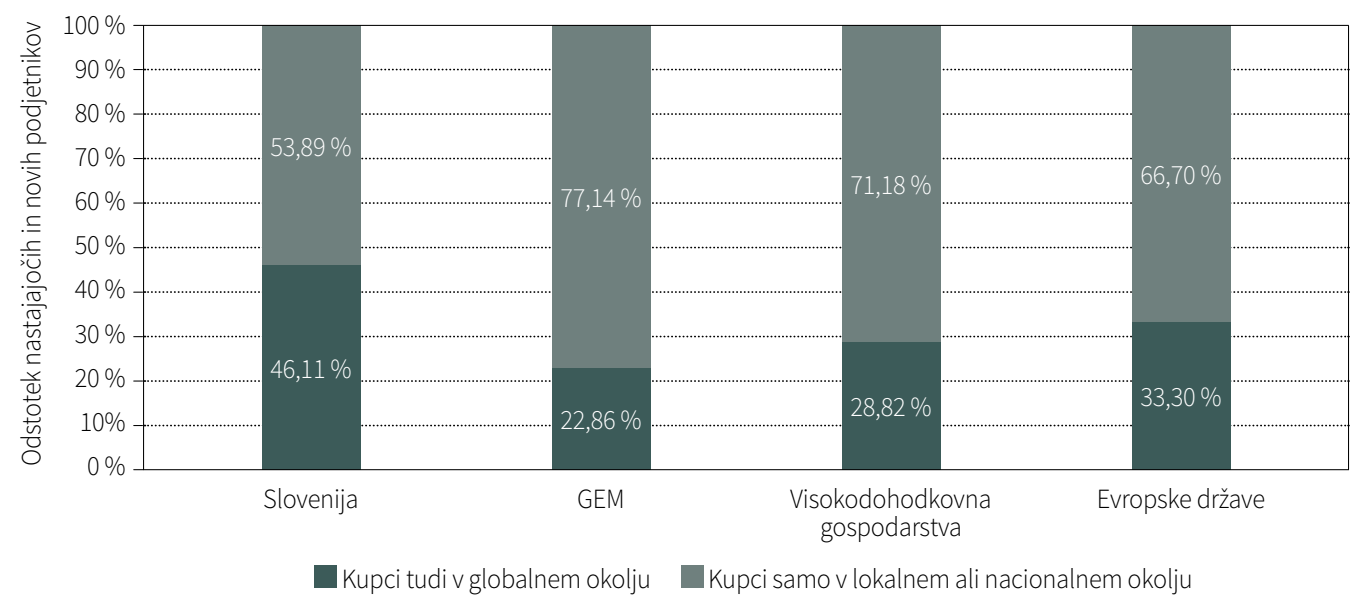

GEM Slovenija 2020, APS

Delež nastajajočih in novih podjetij v Sloveniji, ki imajo kupce $\vee$ globalnih okoljih, torej izven lokalnih in nacionalnih okvirov, je v letu 2020 znašal $46 \%$ (glej sliko 6.5). S tem se je Slovenija v evropskem merilu uvrstila daleč nad povprečje držav, vključenih v raziskavo GEM. O večjem deležu poročajo le podjetniki iz Luksemburga (59\%). Velik delež imajo še ciprska (45\%), grška (42\%) in latvijska podjetja (41\%), o najmanjšem deležu globalnih kupcev pa poročajo podjetniki s Poljske (2 \%), iz Italije (10 \%), Španije (23\%), Rusije (24 \%) in z Norveške (25\%). 
Slika 6.5: Delež kupcev podjetja iz globalnega okolja, v TEA (v evropskih državah GEM)

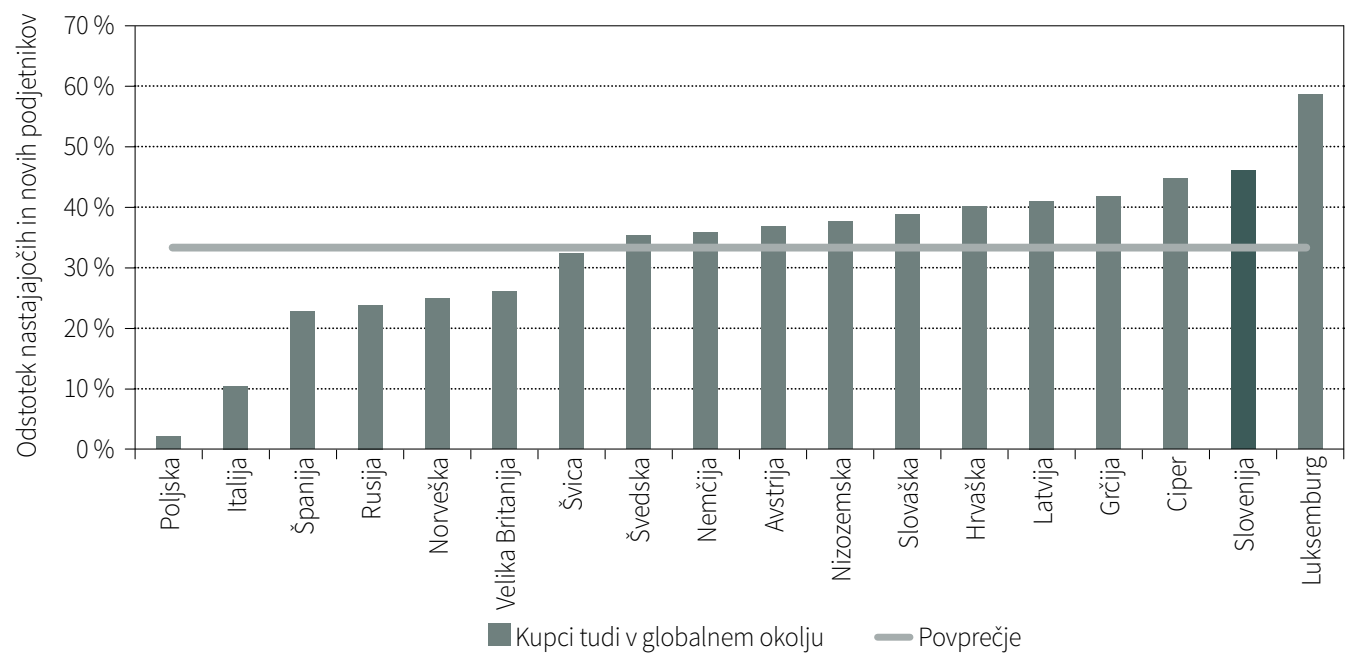

GEM Slovenija 2020, APS

Intenzivnost internacionalizacije v Sloveniji je izrazita, saj je delež nastajajočih in novih podjetij, ki menijo, da je več kot 25 \% kupcev njihovih izdelkov ali storitev iz tujine, večji kot v posameznih skupinah držav, vključenih v raziskavo GEM. Kot je prikazano na sliki 6.6, je bilo takšnih podjetij v letu 2020 v Sloveniji 21 \%, kar je več kot v posameznih skupinah držav (države GEM 10 \%, države iz skupine visokodohodkovnih gospodarstev $13 \%$, evropske države $16 \%$ ).

Slika 6.6: Intenzivnost internacionalizacije nastajajočih in novih podjetnikov po skupinah držav

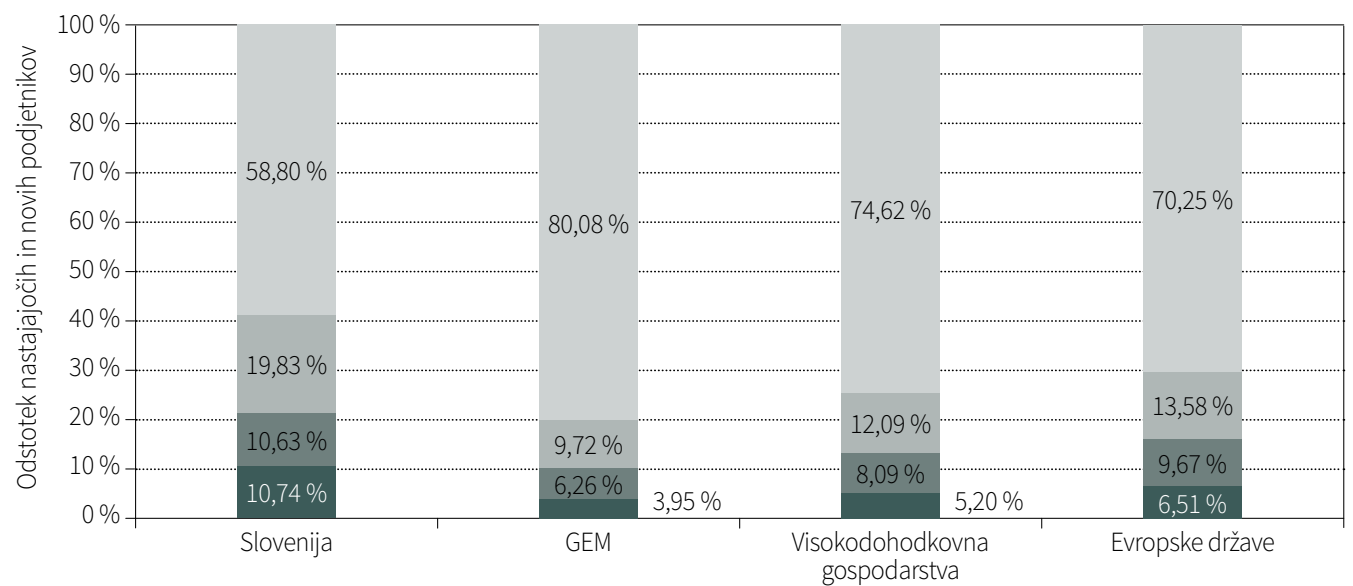

75-100\% prihodkov zunaj države

1-25\% prihodkov zunaj države
25-75\% prihodkov zunaj države

Nobenih prihodkov zunaj države 
Kot je prikazano na sliki 6.7, so bile v letu 2020 najvišje stopnje internacionalizacije v evropskih državah (več kot $25 \%$ kupcev $v$ tujini) med nastajajočimi in novimi podjetniki izmerjene $v$ Luksemburgu (30 \%), na Cipru (30 \%) in na Hrvaškem (25\%), najnižje stopnje internacionalizacije pa na Poljskem (1\%), v Italiji (5\%) in Španiji (6\%).

Slika 6.7: Intenzivnost internacionalizacije nastajajočih in novih podjetnikov (v evropskih državah GEM), GEM Slovenija 2020, APS

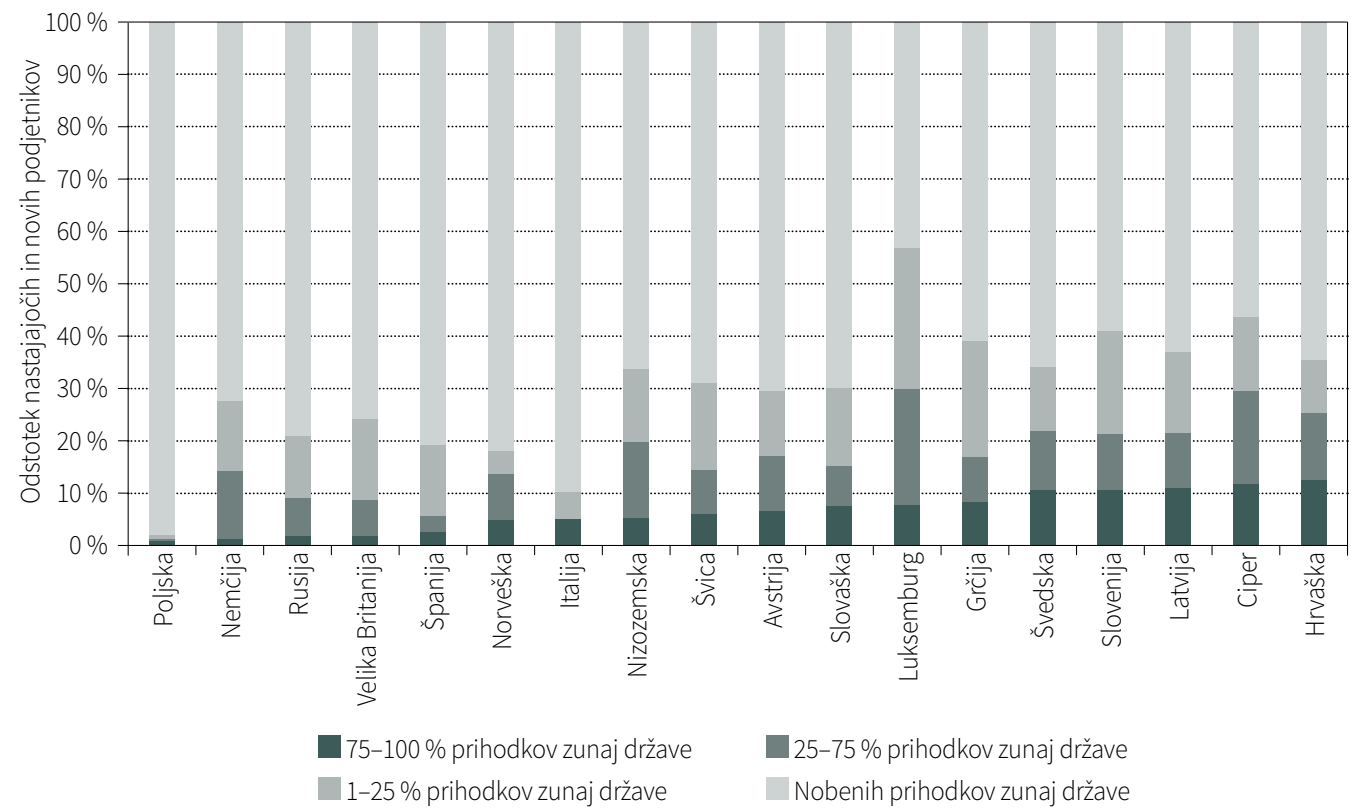

\subsection{Inovacijska naravnanost zgodnjih podjetnikov}

Kot navajata Aulet in Murray (2013), so tako imenovana inovacijsko gnana podjetja s potencialom za rast ključni vir ustvarjanja kakovostnih delovnih mest z visoko dodano vrednostjo. Vodijo jih ambiciozni podjetniki, ki so nadpovprečno samozavestni in premorejo višjo stopnjo podjetniške osredotočenosti za uspešno premagovanje izzivov. Ti podjetniki se tudi hitreje učijo in prilagajajo, pri čemer razvoj podjetja temelji na procesu hitrega učenja na osnovi številnejših poskusov in napak.

O inovacijah lahko govorimo, ko podjetja na trg uspešno uvedejo nov izdelek ali storitev, izboljšajo organizacijo dela oziroma proizvodni proces z uvedbo novih tehnologij ali pa uveljavijo nov, inovativen poslovni model. Zahtevnejše oblike inovacij so praviloma rezultat procesa ciljnih vlaganj $\checkmark$ raziskave in razvoj ter $v$ komercializacijo izumov ali drugih rešitev, razvitih $v$ procesu inoviranja. Podrobnejši pregled literature o obravnavani tematiki sta sicer že pred časom pripravila Carre in Thurik (2006). 
Podjetnikova inovacijska naravnanost igra pomembno vlogo pri določanju stopnje inovacijske moči podjetja, ki je prav tako odvisna od vpetosti podjetja v medpodjetniške in raziskovalne mreže, razvojnega sodelovanja s kupci in dobavitelji, pa tudi od inoviranju naklonjenega poslovnega okolja. Proučujemo razpon novosti novih izdelkov in storitev podjetij ter razpon novosti njihovih uporabljenih tehnologij in procesov, s čimer želimo meriti in proučevati inovacijsko moč podjetij. Pri tem razlikujemo, ali so te novosti nove le na lokalni ravni ali pa tudi na nacionalni ali celo na globalni ravni. Za mnenje o tem povprašamo podjetnike, saj ti najboljevedo, ali njihovi (potencialni) kupci že poznajo izdelek ali storitev, sorodna tistima, ki ju trži nastajajoče ali novo podjetje, in sicer, ali to drži na lokalni, nacionalni ali globalni ravni.

Slika 6.8: Delež podjetnikov, ki dosegajo vsaj nacionalni oziroma vsaj globalni razpon, in sicer hkrati z vidika trga in novih izdelkov, storitev ali procesov, v celotni populaciji po skupinah držav

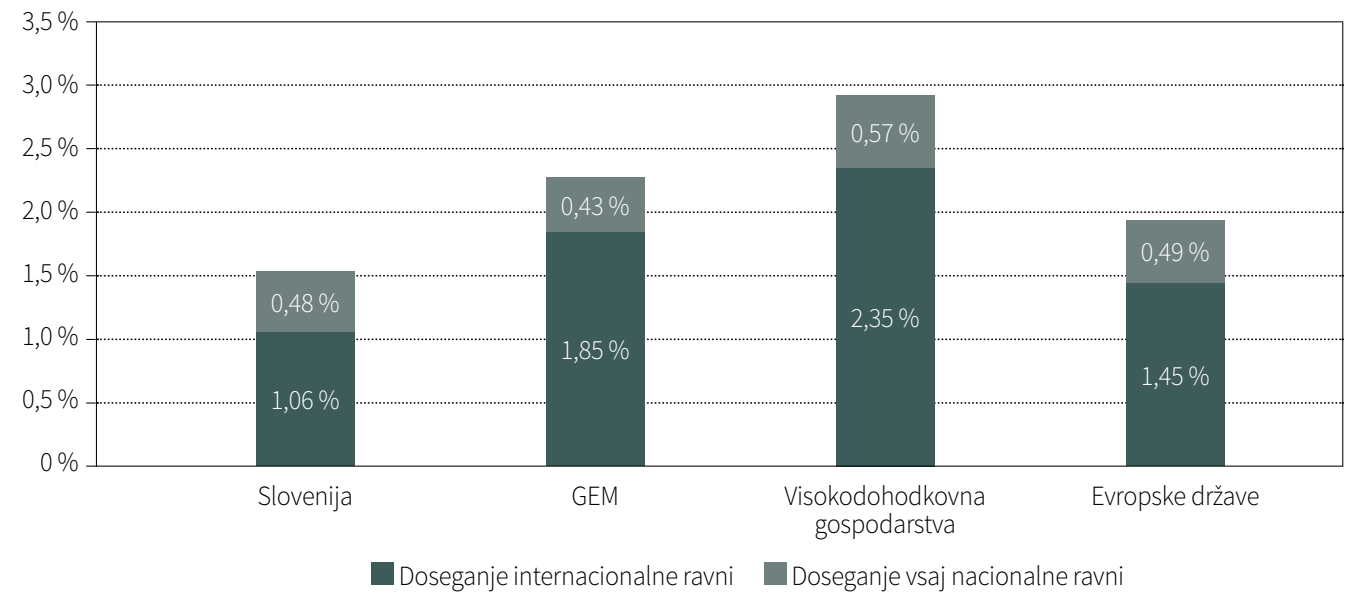

GEM Slovenija 2020, APS

Na sliki 6.8 je prikazan razpon poslovanja podjetij, vezan na doseganje vsaj nacionalnega ali vsaj internacionalnega trga, ob hkratnem doseganju kriterija, da so njihovi proizvodi, storitve ali procesi novi na nacionalni oziroma internacionalni ravni. Delež posameznikov med odraslimi prebivalci Slovenije, katerih podjetja dosegajo vsaj nacionalno raven trga in hkrati so tudi njihovi izdelki, storitve ali procesi novost na vsaj nacionalnem trgu, je znašal 1,06\%, kar je delež, zelo primerljiv z deležem v posameznih skupinah držav. Na sliki 6.9 pa je prikazana primerjava z drugimi evropskimi državami, vključenimi v raziskavo GEM, kjer se Slovenija uvršča pod povprečje evropskih držav. Največji delež posameznikov med odraslimi prebivalci, katerih podjetja dosegajo nacionalno raven po obeh kriterijih, je na Slovaškem (2,91 \%), najmanjši pa na Poljskem (0,42 \%) in v Španiji $(0,44 \%)$. 
Slika 6.9: Delež podjetnikov, ki dosegajo vsaj nacionalno raven, in sicer hkrati z vidika trga in novih izdelkov, storitev ali procesov, v celotni populaciji (v evropskih državah GEM)

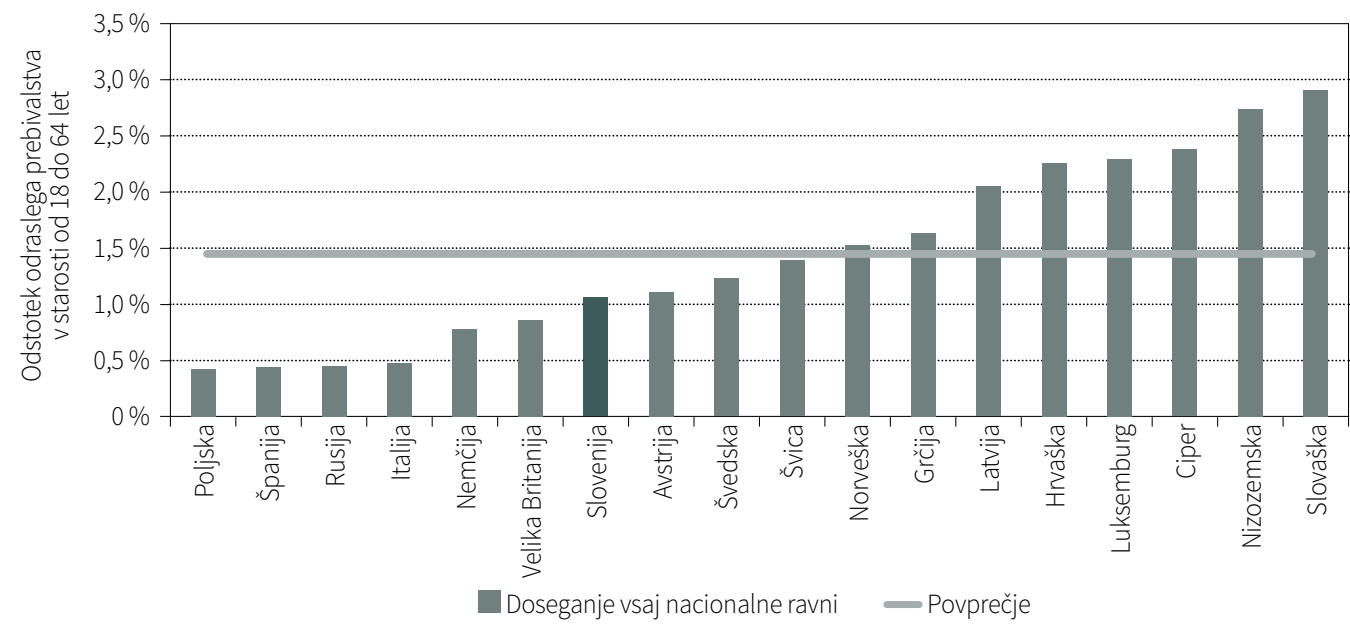

GEM Slovenija 2020, APS

Na sliki 6.10 je prikazan delež podjetnikov kot delež odraslega prebivalstva v evropskih državah, vključenih v raziskavo GEM, ki s svojimi proizvodi dosegajo vsaj internacionalni trg, hkrati pa so njihovi izdelki, storitve in procesi novi vsaj na internacionalni ravni. Ta delež je leta 2020 za Slovenijo znašal 0,48 \%, s čimer se Slovenija uvršča v povprečje evropskih držav, vključenih $\checkmark$ raziskavo GEM. Največji delež posameznikov med odraslimi prebivalci, katerih podjetja dosegajo internacionalno raven po obeh kriterijih, je na Slovaškem (1,21\%), najmanjši pa na Poljskem (0,01\%) in v Italiji (0,02\%).

Slika 6.10: Delež podjetnikov, ki dosegajo vsaj globalno raven, in sicer hkrati z vidika trga in novih izdelkov, storitev ali procesov, v celotni populaciji (v evropskih državah GEM)

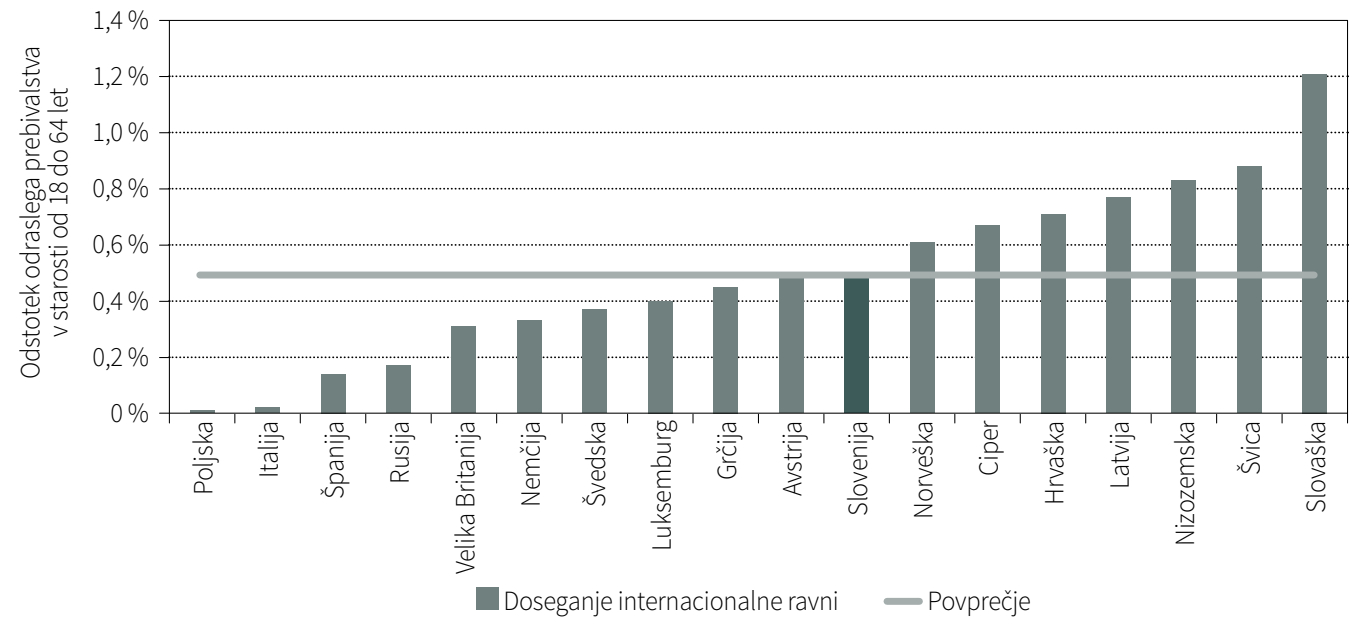


Na sliki 6.11 je prikazan delež podjetnikov kot delež odraslega prebivalstva v evropskih državah, vključenih v raziskavo GEM, ki s svojimi proizvodi dosegajo skupaj vsaj nacionalni ali vsaj internacionalni trg, hkrati pa so njihovi izdelki, storitve ali procesi novi vsaj na nacionalni ali na internacionalni ravni. Ta delež je leta 2020 za Slovenijo znašal 1,54 \%, s čimer se naša država uvršča v spodnjo polovico evropskih držav, vključenih v raziskavo GEM. Največji delež posameznikov med odraslimi prebivalci, katerih podjetja dosegajo ali nacionalno ali internacionalno raven po obeh kriterijih, je na Slovaškem (4,12 \%) in na Nizozemskem (3,57 \%), najmanjši pa na Poljskem (0,43 \%) in v Španiji (0,58 \%).

Slika 6.11: Deležpodjetnikov, ki dosegajo vsaj nacionalno ali vsaj globalno raven, in sicer hkrati zvidika trga in novih izdelkov, storitev ali procesov, v celotni populaciji (v evropskih državah GEM)

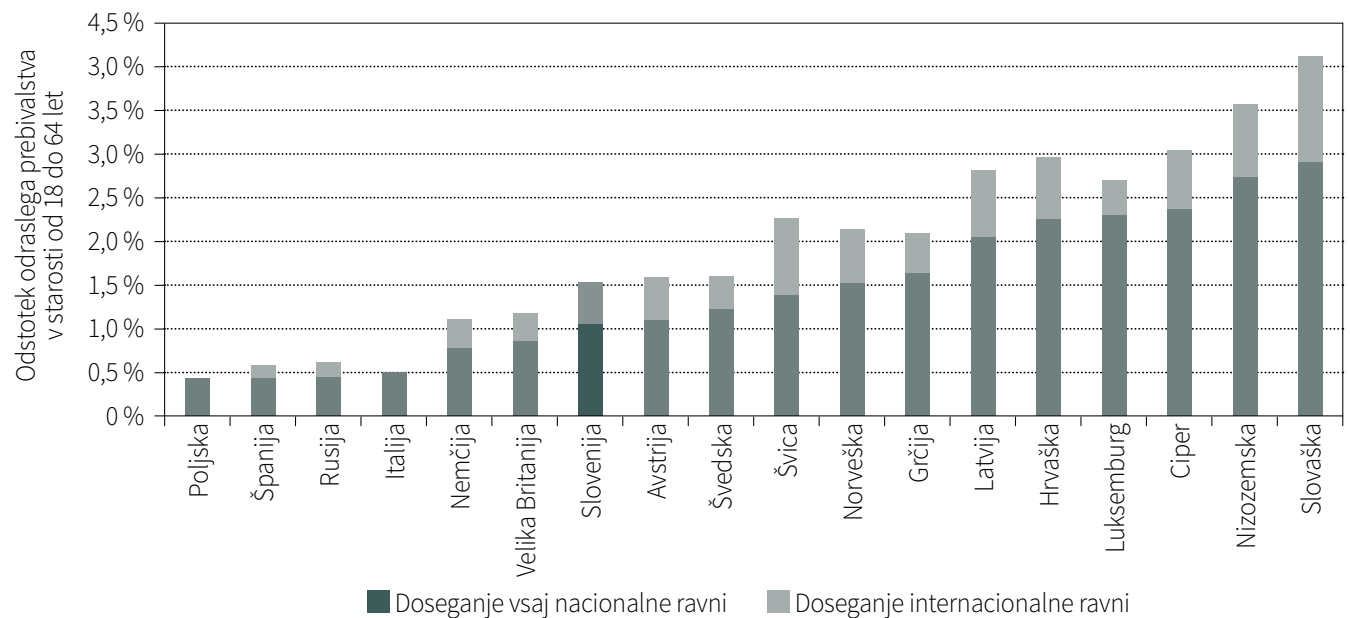

GEM Slovenija 2020, APS

Podatki o mednarodni vpetosti slovenskih podjetnikov in predvsem inovacijsko gnanih podjetij so dokaj spodbudni. Ključno je, da država nadaljuje s procesi izboljšav poslovnega okolja in podpore najambicioznejšim podjetnikom, da bi ohranili in še okrepili dejavnosti podjetij v Sloveniji. To je še posebej pomembno $v$ teh časih, ko je poslovno okolje dodobra razburkala negotovost zaradi pandemije. Treba se je tudi zavedati, da podjetja rastejo kot rezultat zavestne in načrtovane aktivnosti podjetnika, za kar mora podjetnik zagotoviti ustrezne in zadostne vire, prav tako pa mu morajo biti pri tem naklonjeni ugodni okvirni pogoji poslovnega okolja, v katerem deluje.

Podjetjem moramo zato omogočiti podporo pri rasti in na področju inovativnosti, da bi tako čim bolj omilili negativne posledice vplivov poslovnega okolja. Zavedati se je tudi treba, da se krepi konkurenca med državami, ki se vse bolj zavedajo pomena talentov in inovacijsko gnanih podjetij ter aktivno vabijo podjetja v svoja okolja. Podjetja pa so zaradi narave dela in poslovanja tudi vedno bolj fleksibilna glede lokacije svojih aktivnosti, ki jih lahko deloma ali v celoti preselijo tudi $\checkmark$ druga poslovna okolja in na ta način zmanjšajo prispevek $k$ ustvarjanju kakovostnih delovnih mest v Sloveniji. Za našo državo je ključnega pomena, da podjetniki inovacijsko gnanih podjetij dejavnosti ohranjajo v Sloveniji.

Nadgrajeno in bolj konkurenčno poslovno okolje bo okrepilo pozitivne elemente, povezane z ambicioznimi podjetniki, ki delujejo v svojem domačem okolju in v podjetjih angažirajo talentirane posameznike, prav tako pa so tudi najboljši promotorji slovenskega znanja in tehnologij. Pri tem bi veljalo močno okrepiti povezave med raziskovalno sfero in podjetji in tako dejansko sprostiti velik 
neizkoriščen potencial ter bistveno okrepiti raziskovalno-razvojne aktivnosti podjetij, kar bo lahko vodilo k dodatni krepitvi proizvodnih in drugih poslovnih kapacitet v Sloveniji.

Prav tako je pomembno poudariti in se zavedati, da rast podjetja podjetniku ne prinaša samo prednosti oziroma koristi, ampak tudi številne izzive in slabosti ter predvsem tveganja. Če tega ne znamo ceniti in pravilno vrednotiti ter predvsem pravilno razumeti, tvegamo, da se podjetniški potenciali posameznikov ne bodo izrazili v želeni smeri. Tudi podjetniki so samo ljudje, ki tehtajo prednosti in slabosti, kar se lahko dogaja na zavedni ali nezavedni ravni in lahko pretehta tudi v smeri, ki podjetnike odvrnejo od zasledovanja zelo ambicioznih načrtov. Ker je delež ambicioznih in nadpovprečno sposobnih in motiviranih podjetnikov zelo omejen, se mora država še naprej osredotočati na razvoj ukrepov in programov, namenjenih inovacijsko gnanim podjetjem (tako startupom kot scaleupom oziroma visokotehnološkim gazelam).

Kot navaja Lafuente s sodelavci (2020), države vse več sredstev usmerjajo v spodbujanje nastajanja novih podjetij in zaposlovanja, pri čemer je pomembno, da so podjetja deležna podpore tudi v nadaljnjih fazah razvoja, ko se soočajo z izzivi rasti. Ob umanjkanju mehanizmov podpore za rast in razvoj podjetij se lahko namreč zgodi, da z rastjo naletijo na prevelike ovire in izzive v poslovnem okolju, s katerimi se ne morejo uspešno soočiti, in predčasno zaključijo s poslovanjem. Prav tako je pomembno, da je država intenzivno podprla podjetja, prizadeta zaradi pandemije.

Raziskava GEM in rezultati drugih podjetniških raziskav so lahko državi in ključnim odločevalcem v njej v veliko podporo. Boljše poznavanje značilnosti podjetij in podjetnikov ter zmožnost njihove segmentacije so zelo pomembni, saj izvajalcem razvojnih vladnih politik omogočajo še bolj ciljno usmerjeno sprejemanje ukrepov ter posledično doseganje njihove večje učinkovitosti. Pri tem imamo v mislih na primer izvajanje vladnega programa Slovenija dežela startup podjetij, ki je že odpravil številne identificirane ovire v poslovnem okolju, nekatere pa bo še treba odpraviti in zagotoviti mednarodno konkurenčno poslovno okolje. Kot navaja Morales-Alonso s sodelavci (2020), je zelo pomembno, da se izvajalci vladnih politik zavedajo, da lahko pospešijo inovacije in podjetništvo tako, da izboljšajo dostope do znanja in tehnologij za vse prebivalce, da zmanjšajo obseg korupcije, da izboljšajo dostope do virov financiranja in zmanjšajo birokratske ovire.

Veseli nas, da se v zadnjih letih v Sloveniji počasi, a vztrajno krepi zavedanje o pomenu inovacijsko gnanih podjetij, ki jih ustanavljajo in vodijo ambiciozni podjetniki. Deloma so k temu prispevali uspehi in merljivi učinki podjetij, deloma različne študije, kot je tudi raziskava GEM. Večje zavedanje izvajalcev vladnih politik je privedlo tudi do povečanega vlaganja energije in naporov, usmerjenih v podporo podjetjem pri zagotavljanju različnih virov, pa tudi v ustvarjanje ugodnejših okvirnih pogojev za poslovanje podjetij. S tem se krepijo pogoji za aktivacijo razpoložljivega podjetniškega talenta in privabljanje novega talenta. Pri tem moramo prisluhniti ugotovitvam Puente in sodelavcev (2017), ki ugotavljajo, da višje stopnje izobrazbe prispevajo k večji verjetnosti, da imajo ljudje tudi večje aspiracije po rasti, kar je tudi sicer v skladu s številnimi drugimi študijami. Zato je še toliko bolj pomembno, da se $v$ Sloveniji potrudimo reformirati inovacijski sistem in bolje povezati javne raziskovalne organizacije in podjetja. S tem bi se lahko nadejali močnejšega pospeška inovacijske dejavnosti novih in obstoječih podjetij, kar bi zelo pozitivno prispevalo $h$ komercializaciji novih znanj in tehnologij ter k ustvarjanju kakovostnih delovnih mest in krepitvi družbene blaginje. 


\section{Družinsko podjetništvo}

\section{Ključna spoznanja:}

- Med nastajajočimi in novimi podjetji v Sloveniji je $85 \%$ vseh podjetij družinskih, med njimi pa prevladujejo tista, pri katerih družina sodeluje $v$ vodenju, ne pa tudi v lastništvu podjetja - takih je 66,9\% vseh novonastajajočih podjetij.

- V $\quad$ 26,9 \% družinskih podjetij v Sloveniji sodelujejo družinski člani tako v lastništvu kot tudi v vodenju nastajajočih in novih podjetij.

- VSlovenijije večina ustaljenih podjetij družinskih (96,4\%), najpogostejša oblika družinskega podjetništva, ki zajema skoraj tri četrtine vseh ustaljenih podjetij, pa je tista, pri kateri družinski člani sodelujejo v vodenju, ne pa tudi v lastništvu podjetja.

- Manj kot četrtina ustaljenih podjetij vključuje družinske člane tako v vodenje kot tudi v solastništvo podjetja.

- Delež visoko inovativnih podjetij je v vseh geografskih regijah sveta za nedružinska podjetja večji kot za družinska. Razlika v korist nedružinskih podjetij v primerjavi z družinskimi je največja v evropskih državah.

- Slovenija se med družinskimi in nedružinskimi podjetji po kazalniku inovativnosti uvršča nad povprečje evropskih držav, a pod povprečje razvitih držav Severne Amerike in Azije, pa tudi pod povprečje držav GEM.

- Povezava med kazalnikom inovativnosti in bruto nacionalnim dohodkom na prebivalca kaže na to, da podjetniki v gospodarstvih z višjo stopnjo razvoja zaznavajo manj možnosti za uvedbo novih in inovativnih gospodarskih dejavnosti in težje izkazujejo inovativnost in novosti. 


\subsection{Družinska podjetja v raziskavi GEM}

Čeprav se opredelitve družinskih podjetij razlikujejo glede na značilnosti vpetosti družine v podjetje (lastništvo in vodenje, generacija družine), pa tudi glede na značilnosti gospodarskih sistemov, ni dvoma, da veliko prispevajo k zaposlovanju in gospodarski rasti (Astrachan in Shanker, 2003). $\checkmark$ enem od poročil o družinskih podjetjih (KMU Forschung Austria, 2008) je navedenih skupaj 90 različnih opredelitev družinskega podjetja po Evropi. Vsem je skupno sodelovanje družine v lastništvu in/ali vodenju podjetja, vendar stopnja družinske vpletenosti ni enaka za vsa družinska podjetja (Westhead in Cowling, 1998; Sharma, 2004; Herero, 2017). Družinska dinamika se sčasoma spreminja, na primer od družinskih podjetij prve generacije (ustanovna generacija) do bolj zrelih podjetij druge in nadaljnjih generacij, pri čemer se družinska podjetja pri tem soočajo še z nasledstvenimi težavami (Ljubotina in Vadnjal, 2017).

V letu 2018 je raziskovanje družinskega podjetništva predstavljalo posebno tematiko v okviru raziskave GEM, v kateri je sodelovalo 48 držav, med njimi tudi Slovenija.

Družina je lahko v podjetniško aktivnost vključena s solastništvom in/ali vodenjem. Kot je prikazano na sliki 7.1, obstajajo tri oblike, ki jih v GEM označujemo kot družinsko podjetništvo: 1) družinski člani so lahko solastniki in vodijo podjetja, 2) družinski člani so lahko solastniki podjetja, a jih ne vodijo, ali 3) družinski člani niso solastniki podjetja, ampak so vključeni v njegovo vodenje. Vsaka od teh treh oblik predstavlja močno vključenost družine in jih skupaj obravnavamo kot oblike družinskega podjetništva (Kelley et al., 2020).

Slika 7.1: Oblike družinskega podjetništva v GEM, GEM Family Business 2018, APS

\begin{tabular}{|l|r|r|} 
& $\begin{array}{r}\text { Družinski člani } \\
\text { niso solastniki podjetja }\end{array}$ & $\begin{array}{r}\text { Družinski člani } \\
\text { so solastniki podjetja }\end{array}$ \\
\hline Družinski člani sodelujejo v vodenju & Družinsko podjetje & Družinsko podjetje \\
\hline Družinski člani ne sodelujejo v vodenju & Nedružinsko podjetje & Družinsko podjetje \\
\hline
\end{tabular}

Pri pregledu zgodnje podjetniške aktivnosti lahko ugotovimo, da v Vzhodni in Južni Aziji v bistvu celotna zgodnja podjetniška aktivnost vključuje (širšo) družino. Na Japonskem, Tajvanu in Kitajskem je delež družinskega podjetništva najmanjši - nekaj več kot 40 \% celotne zgodnje podjetniške aktivnosti. V Evropi in Severni Ameriki se vključenost družine v zgodnji podjetniški aktivnosti giblje med 54 \% v Turčiji do 90 \% na Poljskem.

Najpogostejša oblika družinskega podjetništva v zgodnji podjetniški aktivnosti je vodenje brez solastništva. Velik delež te oblike družinskega podjetništva, približno 85 \% ali več celotne zgodnje podjetniške aktivnosti družinskega podjetništva, prevladuje v štirih gospodarstvih iz različnih regij: Madagaskar, Panama, Indonezija in Poljska. Na drugi strani pa Kitajska poroča le o 12-odstotnem vodenju brez solastništva. Naslednja najpogostejša oblika družinskega podjetja je solastništvo z vodenjem. Ta oblika označuje več kot tretjino družinskih podjetnikov v Kolumbiji, Urugvaju in Združenih arabskih emiratih, vendar manj kot $5 \%$ vse zgodnje podjetniške aktivnosti družinskega podjetništva v Republiki Koreji. Tako obliko družinskega podjetništva, da bi bili podjetniki, ki so Člani družine, tudi solastniki, vendar ne bi sodelovali tudi v vodenju družinskega podjetja, pa srečamo le redko. V številnih gospodarstvih (Tajska, Portoriko, Bolgarija, Velika Britanija, Rusija, Ciper in Francija) te oblike ne prepoznavajo kot oblike družinskega podjetništva. Najvišjo stopnjo te oblike lahko opazimo v Argentini (18\%). 
Obseg družinskega podjetništva v zgodnji podjetniški aktivnosti po državah GEM je prikazan na sliki 7.2 .

Slika 7.2: Obseg družinskega podjetništva v zgodnji podjetniški aktivnosti

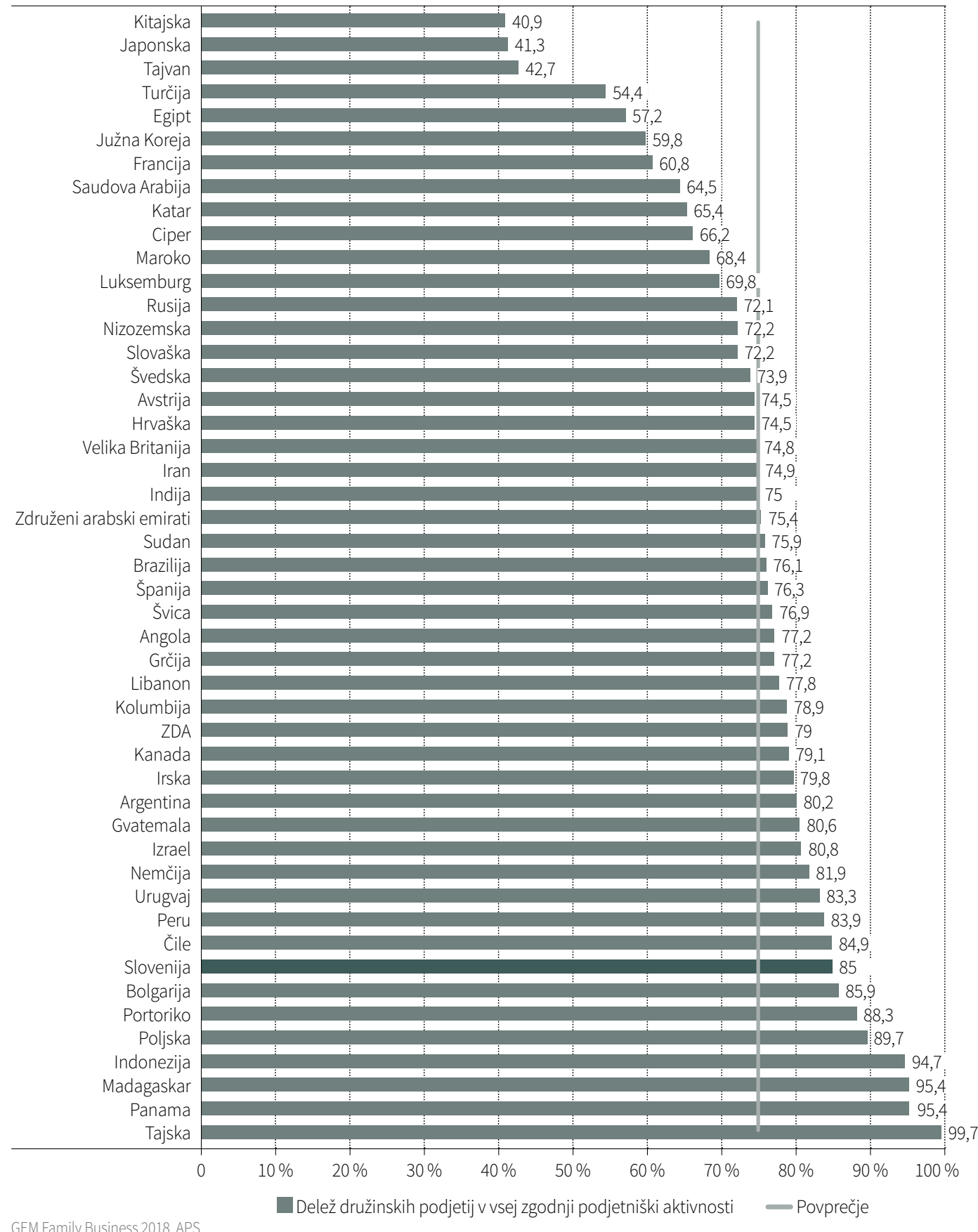


Med ustaljenimi podjetji lahko pri primerjavi zgodnje podjetniške aktivnosti opazimo podobnosti. Vsi uveljavljeni lastniki podjetij na Tajskem in 94 \% v Indoneziji so navedli, da v podjetniške aktivnosti vključujejo družino. Po drugi strani je to predstavljalo manjši delež ustaljenega podjetništva na Kitajskem (30\%). Države srednje Evrope (Slovenija, Slovaška, Poljska in Hrvaška) in Bolgarija poročajo, da je več kot 90 \% ustaljenih podjetij družinskih. Tudi v Latinski Ameriki je vključenost družine v ustaljenem podjetništvu sorazmerno velika, na primer v Argentini (92\%) ali v Panami (99 \%), kjer torej predstavlja skoraj celotno ustaljeno podjetništvo. Poleg že omenjene Kitajske je tudi na Bližnjem vzhodu in v Afriki opazen kontrast: na primer na Madagaskarju in v Libanonu je stopnja ustaljenega podjetništva med prebivalstvom 22-odstotna, vendar na Madagaskarju $97 \%$ vseh ustaljenih podjetnikov vključuje družino, v Libanonu pa je takih manj kot $70 \%$.

Glede oblike družinskega podjetništva v ustaljeni podjetniški aktivnosti velja, da blizu $40 \%$ ali več uveljavljene poslovne dejavnosti v vseh gospodarstvih GEM vključuje člane družine v vodenje, vendar ne tudi v lastništvo; izjema je Kitajska, kjer je ta delež le 9-odstoten. Oblika družinskega podjetništva, ki vključuje sodelovanje družine v vodenju in v lastništvu, predstavlja približno 30 \% ustaljenega podjetništva $v$ Luksemburgu, Združenih arabskih emiratih in Kanadi. V nasprotju s tem je v Južni Koreji, Indoneziji, Izraelu, Panami in na Madagaskarju le $4 \%$ ali manj te oblike med ustaljenimi podjetji. Tudi med ustaljenimi podjetniki je sodelovanje družine v lastništvu, a brez vodenja redko; tako na Tajskem, v Indoneziji, Panami, Peruju, Gvatemali, Izraelu, Libanonu, Sudanu in Ruski federaciji ni nobenega družinskega podjetja takšne oblike. Obseg družinskega podjetništva v ustaljeni podjetniški aktivnosti je prikazan na sliki 7.4.

Slika 7.3: Delež slovenskih družinskih podjetij v zgodnji in ustaljeni podjetniški aktivnosti

\section{Delež družinskih podjetij v zgodnji podjetniški aktivnosti}

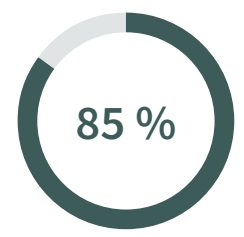

Delež družinskih podjetij v ustaljeni podjetniški aktivnosti

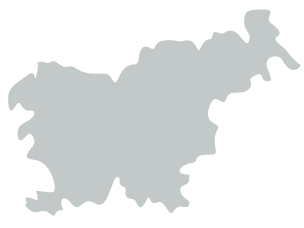

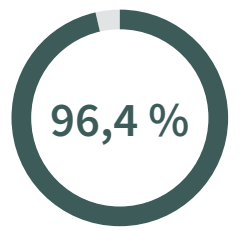


Slika 7.4: Obseg družinskega podjetništva v ustaljeni podjetniški aktivnosti

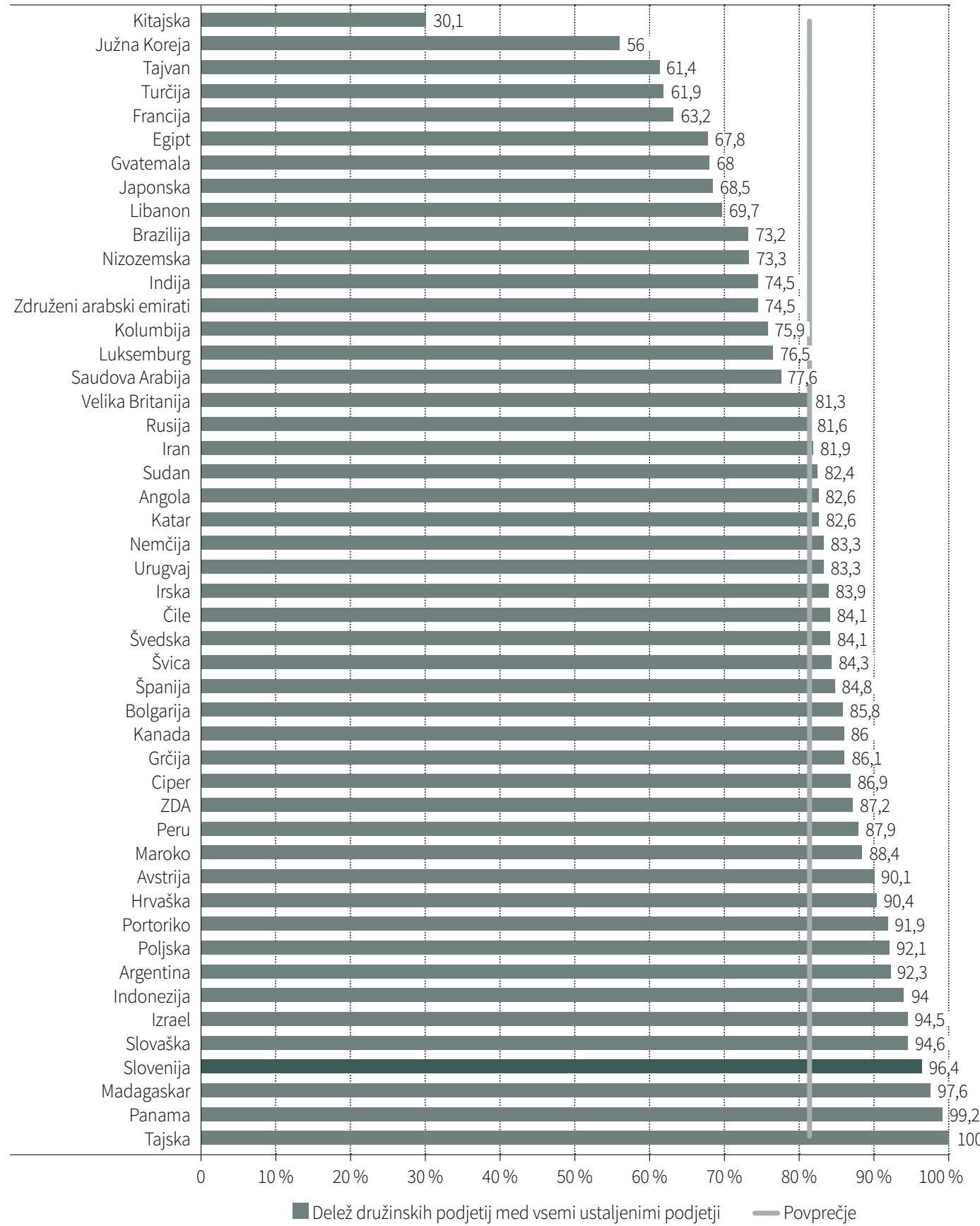


Slika 7.5: Oblike in obseg družinskega podjetništva v Sloveniji

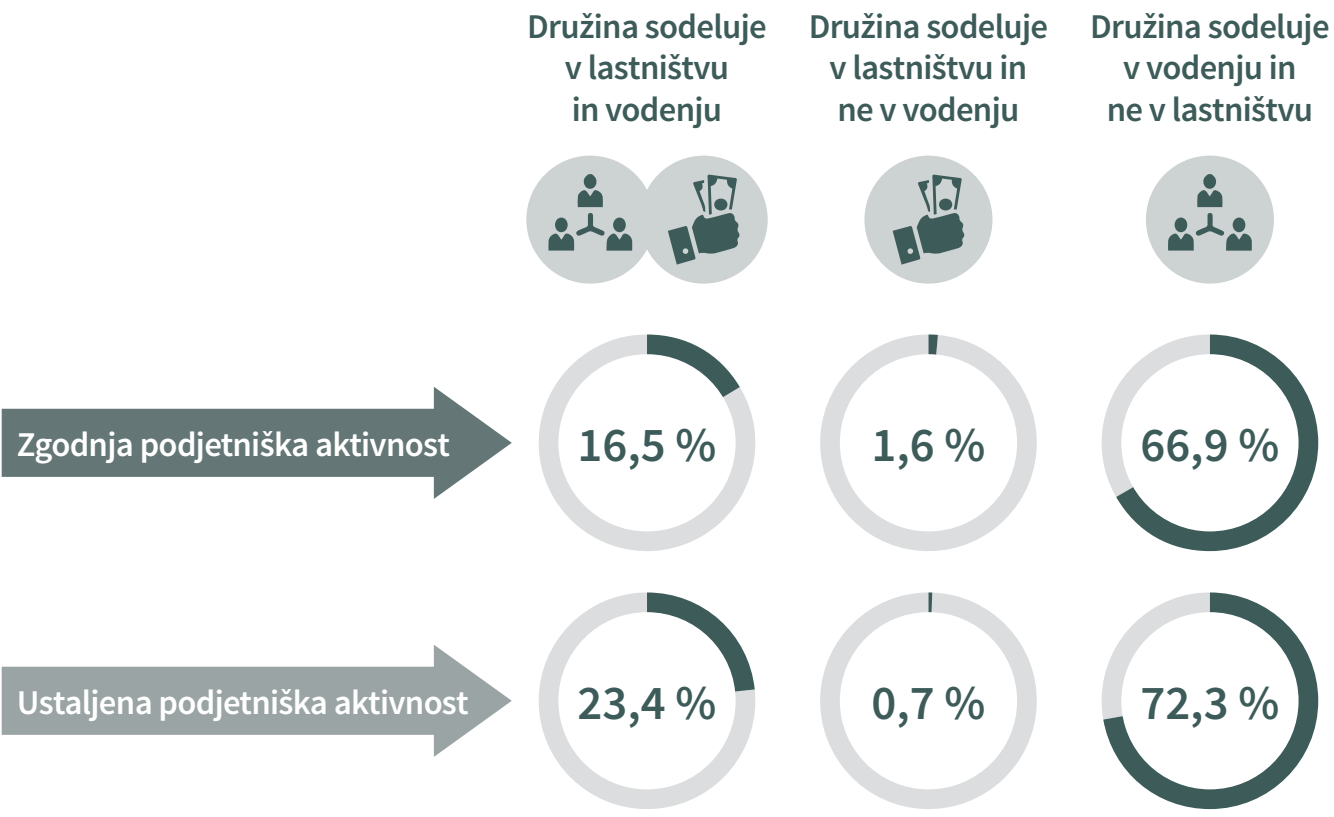

GEM Family Business 2018, APS

Na sliki 7.5 prikazujemo oblike in obseg družinskega podjetništva v Sloveniji. Podatki kažejo, da je $\checkmark$ Sloveniji večina ustaljenih podjetij družinskih, najpogostejša oblika družinskega podjetništva, ki zajema skoraj tri četrtine vseh ustaljenih podjetij, pa je tista, pri kateri družinski člani sodelujejo v vodenju, ne pa tudi pri lastništvu podjetja. Manj kot četrtina ustaljenih podjetij vključuje družinske člane tako v vodenje kot tudi v solastništvo podjetja.

Med nastajajočimi in novimi podjetji je prav tako velika večina družinskih, in sicer 85 \% vseh podjetij, tudi med njimi pa prevladujejo tista družinska podjetja, pri katerih družina sodeluje $v$ vodenju, ne pa tudi v lastništvu podjetja.

\subsection{Inovativnost družinskih podjetij}

$\checkmark$ raziskovanju inovativnosti družinskih podjetij (zgodnja podjetniška aktivnost) so bili kot družinski podjetniki oziroma podjetniki družinskih podjetij opredeljeni tisti, katerih podjetja so (ali se pričakuje, da bodo) v večinski lasti in jih večinoma vodi ena (širša) družina (in to ni enoosebno podjetje).

Z vidika konkurenčnosti nacionalnih gospodarstev inovativnost pomembno prispeva $h$ kakovostnemu podjetništvu. Toda inovativnosti ni mogoče enostavno opisati, še posebej, ker inovativnost zajema širok nabor različnih vidikov in zaznav. Podjetniška inovativnost je odvisna tako od posameznih dejavnikov kot od okolja, v katerem posameznik deluje (Širec in Močnik, 2016). V okviru GEM opazujemo inovativnost podjetij s tržnega vidika, s poudarkom na podjetnikovem dojemanju trga, s katerim se sooča; GEM podjetnike sprašuje o novosti uporabljene tehnologije (oziroma o namerah njene uporabe), novosti izdelka ali storitve za kupce ali potencialne kupce in 
o stopnji konkurence na trgu, na katerem deluje ali želi nanj vstopiti. Tisti z visoko stopnjo zaznane inovativnosti zato menijo, da se njihova podjetja bistveno razlikujejo od obstoječih organizacij na trgu in da njihova dejavnost temelji na novih postopkih ter predstavlja novo ponudbo izdelkov/ storitev. Podjetja z nizko stopnjo inovativnosti delujejo v stabilni populaciji, katere rutine, kompetence in ponudbe se od obstoječih organizacij razlikujejo le minimalno (če sploh). Na podlagi opisanih značilnosti se identificirajo inovativni in imitativni podjetniki (Koellinger, 2008).

Kar zadeva merilo inovativnosti, moramo poudariti, da je koncept, razvit v okviru GEM, poenostavljen in se precej razlikuje od koncepta, operacionaliziranega v smislu patentov, izdatkov za raziskave in razvoj itd. $\vee$ tem poglavju je torej inovativnost podjetniške aktivnosti opisana s tem, kako podjetniki dojemajo različne vidike uvajanja nove gospodarske dejavnosti (z vidika nove tehnologije, z vidika novosti izdelkov/storitev in z vidika zaznavanja konkurence). V okviru raziskovalnega okvira GEM podjetniki zato ocenjujejo svoje dojemanje treh inovativnih vidikov svojih podjetniških prizadevanj - dejansko (objektivno) stanje inovativnosti ni ugotovljeno. Zelo verjetno je, da je takrat, ko je gospodarstvo bolj razvito, stopnja zaznavanja novosti novih izdelkov in/ali storitev nižja. Zato je treba rezultate razlagati glede na razvoj obravnavanega gospodarstva (ali trga) (Tominc in Širec, 2020).

Kar zadeva geografsko porazdelitev, je mogoče opaziti jasen vzorec razlik med družinskimi in nedružinskimi podjetji, ki je v vseh preiskovanih svetovnih regijah precej skladen. Delež visoko inovativnih podjetij je $v$ vseh geografskih regijah sveta za nedružinska podjetja večji kot za družinska. Razlika v korist nedružinskih podjetij v primerjavi z družinskimi podjetji je največja $\vee$ evropskih državah, kjer delež visoko inovativnih nedružinskih podjetij presega delež družinskih podjetij za deset odstotnih točk; razlika je najmanjša v Južni in Vzhodni Aziji, kjer družinska podjetja zaostajajo za dve odstotni točki, medtem ko na Bližnjem vzhodu in v severni Afriki družinska podjetja glede na delež visoko inovativnih podjetij vodijo za odstotno točko v primerjavi z nedružinskimi podjetji.

Delež podjetij z nizko stopnjo inovativnosti je v družinskih podjetjih v vseh geografskih regijah večji kot pri nedružinskih. Tako pri družinskih kot pri nedružinskih podjetjih je stopnja dojemanja podjetnikov o uvajanju inovacij na trg najnižja v evropskih državah (med vsemi geografskimi regijami); $43 \%$ družinskih in 33\% nedružinskih podjetij je razvrščenih med nizko inovativna podjetja. Med nedružinskimi podjetji je največji delež visoko inovativnih podjetij $\vee$ Južni in Vzhodni Aziji (37\%) ter na Bližnjem vzhodu in v Severni Afriki (35\%), sledijo Srednja in Južna Amerika (29\%) in podsaharska Afrika (27\%), na koncu lestvice pa so evropske države (24\%). Isti vrstni red, zamenjata se le prvi dve mesti, je med družinskimi podjetji: največji delež visoko inovativnih podjetij je na Bližnjem vzhodu in v Severni Afriki (36 \%), v Južni in Vzhodni Aziji (35 \%), sledijo Srednja in Južna Amerika (26\%) in podsaharska Afrika (20\%), evropske države pa so spet na koncu lestvice (14\%). 
Tabela 7.1: Inovativnost družinskih in nedružinskih podjetij, GEM Family Business 2018, APS

\begin{tabular}{|c|c|c|c|c|c|c|c|}
\hline & & GEM & $\begin{array}{r}\text { Države } \\
\text { podsaharske } \\
\text { Afrike }\end{array}$ & $\begin{array}{r}\text { Bližnji } \\
\text { vzhod in } \\
\text { Severna } \\
\text { Afrika }\end{array}$ & $\begin{array}{r}\text { Južna in } \\
\text { Vzhodna } \\
\text { Azija }\end{array}$ & $\begin{array}{l}\text { Severna } \\
\text { in Južna } \\
\text { Amerika }\end{array}$ & $\begin{array}{r}\text { Evropske } \\
\text { države }\end{array}$ \\
\hline \multirow{4}{*}{$\begin{array}{l}\text { Družinska } \\
\text { podjetja }\end{array}$} & $\begin{array}{l}\text { Visoka } \\
\text { inovativnost }\end{array}$ & $23 \%$ & $20 \%$ & $36 \%$ & $35 \%$ & $26 \%$ & $14 \%$ \\
\hline & $\begin{array}{l}\text { Srednje visoka } \\
\text { inovativnost }\end{array}$ & $44 \%$ & $47 \%$ & $42 \%$ & $44 \%$ & $45 \%$ & $43 \%$ \\
\hline & $\begin{array}{l}\text { Nizka } \\
\text { inovativnost }\end{array}$ & $33 \%$ & $33 \%$ & $21 \%$ & $21 \%$ & $29 \%$ & $43 \%$ \\
\hline & Skupaj & $100 \%$ & $100 \%$ & $100 \%$ & $100 \%$ & $100 \%$ & $100 \%$ \\
\hline \multirow{4}{*}{$\begin{array}{l}\text { Nedružinska } \\
\text { podjetja }\end{array}$} & $\begin{array}{l}\text { Visoka } \\
\text { inovativnost }\end{array}$ & $30 \%$ & $27 \%$ & $35 \%$ & $37 \%$ & $29 \%$ & $24 \%$ \\
\hline & $\begin{array}{l}\text { Srednje visoka } \\
\text { inovativnost }\end{array}$ & $45 \%$ & $49 \%$ & $46 \%$ & $47 \%$ & $47 \%$ & $43 \%$ \\
\hline & $\begin{array}{l}\text { Nizka } \\
\text { inovativnost }\end{array}$ & $25 \%$ & $24 \%$ & $19 \%$ & $17 \%$ & $24 \%$ & $33 \%$ \\
\hline & Skupaj & $100 \%$ & $100 \%$ & $100 \%$ & $100 \%$ & $100 \%$ & $100 \%$ \\
\hline
\end{tabular}

Opisana razporeditev se odraža tudi v povprečnih vrednostih kazalnika inovativnosti, ki ga prikazujemo v tabeli 7.2. Na lestvici od 1 do 3 (razpon za kazalnik inovativnosti) ${ }^{1}$ je najvišja povprečna vrednost dosežena za nedružinska podjetja v državah Južne in Vzhodne Azije $(1,67)$, sledijo pa družinska in nedružinska podjetja na Bližnjem vzhodu in v Severni Afriki (po 1,65). Najnižje povprečne vrednosti kazalnikov najdemo $\vee$ skupini družinskih podjetij $\vee$ podsaharski Afriki $(1,46)$ in v družinskih podjetjih v evropskih državah $(1,37)$.

Tabela 7.2: Kazalnik inovativnosti v družinskih in nedružinskih podjetjih, GEM Family Business 2018, APS

\begin{tabular}{|c|c|c|c|c|c|c|c|c|}
\hline & & GEM & Slovenija & $\begin{array}{r}\text { Države } \\
\text { podsaharske } \\
\text { Afrike }\end{array}$ & $\begin{array}{r}\text { Bližnji } \\
\text { vzhod in } \\
\text { Severna } \\
\text { Afrika }\end{array}$ & $\begin{array}{r}\text { Južna in } \\
\text { Vzhodna } \\
\text { Azija }\end{array}$ & $\begin{array}{l}\text { Severna } \\
\text { in Južna } \\
\text { Amerika }\end{array}$ & $\begin{array}{r}\text { Evropske } \\
\text { države }\end{array}$ \\
\hline $\begin{array}{l}\text { Družinska } \\
\text { podjetja }\end{array}$ & $\begin{array}{l}\text { Povprečje } \\
\text { kazalnika } \\
\text { inovativnost }\end{array}$ & 1,49 & 1,442 & 1,46 & 1,65 & 1,63 & 1,53 & 1,37 \\
\hline $\begin{array}{l}\text { Nedružinska } \\
\text { podjetja }\end{array}$ & $\begin{array}{l}\text { Povprečje } \\
\text { kazalnika } \\
\text { inovativnost }\end{array}$ & 1,59 & 1,586 & 1,55 & 1,65 & 1,67 & 1,59 & 1,52 \\
\hline
\end{tabular}

\footnotetext{
1 Kazalnik je izračunan kot povprečna vrednost treh dimenzij: novost izdelka/storitve za kupce, konkurenčna podjetja in inovativnost tehnologij. Vsaka dimenzija ima tri možne stopnje.
} 
Slovenija se med družinskimi in nedružinskimi podjetji po kazalniku inovativnosti uvršča nad povprečje evropskih držav, a pod povprečja razvitih držav Severne Amerike in Azije, pa tudi pod povprečje držav GEM.

Podjetniška inovativnost je odvisna od okolja, v katerem posamezniki delujejo. Čeprav pretekle raziskave kažejo, da se podjetniki v visoko razvitih državah v povprečju pogosteje ukvarjajo z inovativnimi in ne zgolj imitativnimi dejavnostmi (Koellinger, 2008), se je dojemanje podjetnikov o uvajanju novih gospodarskih dejavnosti danes spremenilo. Povezava med kazalnikom inovativnosti in bruto nacionalnim dohodkom na prebivalca je namreč negativna in statistično značilna (čeprav je moč povezave šibka) tako za skupino družinskih kot tudi nedružinskih podjetij, kar lahko kaže na to, da podjetniki v gospodarstvih z višjo stopnjo razvoja zaznavajo manj priložnosti za uvedbo novih in inovativnih gospodarskih dejavnosti in težje izkazujejo inovativnost in novosti. Zaznavanje inovativnosti je subjektivno in odvisno od položaja opazovalca. Ko se pogled opazovalca nanaša na drugačno perspektivo, postanejo merila za to, kaj je inovativno v podjetniški gospodarski dejavnosti, drugačna (Koellinger, 2008).

Obstaja veliko raziskav o tem, da so značilnosti družbenoekonomskega sistema povezane z razširjenostjo inovativnega podjetništva (Hessels et al., 2008), ti vplivi pa so zelo raznoliki in se nanašajo na različne in večplastne značilnosti. Na primer: dimenzija socialne usmerjenosti države pozitivno in pomembno vpliva na inovativnost zgodnje podjetniške aktivnosti (Urbano et al., 2016); institucionalno okolje, ki spodbuja stabilnost, vodi do več imitacij, če pa institucionalno okolje spodbuja prožnost, spodbuja tudi več inovacij (Young et al., 2018). Prav tako se inovativno podjetništvo v povprečju povečuje, ko imajo posamezniki visoko stopnjo zaznavanja o urejenih institucionalnih pogojih v okolju, pogojih, ki zagotavljajo pravice intelektualne lastnine in predpise o svobodi poslovanja (Raza et al., 2018) itd.

Internacionalizacija (odstotek letnih prihodkov od prodaje strankam, ki živijo zunaj države) je pozitivno in statistično značilno povezana s stališči podjetnikov o njihovi inovativnosti; to lastnost lahko identificiramo v skupini družinskih in nedružinskih podjetij. Nagnjenost podjetnikov k izvozu in dojemanje inovativnosti sta torej pozitivno povezana (Munoz-Bullon et al., 2015).

Medtem ko je raven zaznane inovativnosti med družinskimi podjetji v povprečju nižja po vsem svetu, so nekatere značilnosti obeh skupin podobne: zaznana inovativnost v obeh skupinah družinskih in nedružinskih podjetij je pozitivno povezana s stopnjo zaznane internacionalizacije in hkrati negativno z ravnijo BDP na prebivalca.

Družinska in nedružinska podjetja se torej razlikujejo $v$ povprečni zaznani stopnji inovativnosti ali novosti svojih aktivnosti. To je tudi posledica različnih značilnosti, ki jih lahko pripišemo posameznikom, ki so jedro družinskega podjetja in lahko vplivajo na inovativnost gospodarske dejavnosti, ki jo družinsko podjetje ponuja trgu. Družinska podjetja so na primer manj nagnjena k tveganju v primerjavi z nedružinskimi podjetji; da bi se družinska podjetja izognila poslovnemu neuspehu ali izgubi nadzora, pogosto obravnavajo izogibanje velikim tveganjem kot ustrezen pristop (Hiebl, 2014), po drugi strani pa je inovativnost povezana z večjo stopnjo tveganja (Kraiczy et al., 2015). Prav tako se socialni kapital družinskih podjetij razlikuje od socialnega kapitala nedružinskih podjetij (Levie in Lerner, 2009), mreže in vezi v družinskih podjetjih so drugačne saj se z mreženjem zasebne sfere ( $z$ družino in prijatelji) zmanjšuje inovativnost; inovativnost se namreč v povprečju poveča z mreženjem v javni sferi (s strokovnjaki, na delovnem mestu itd.) (Schott in Sedaghat, 2014). Tako lahko ta dejstva deloma prispevajo k povprečno manjši inovativnosti družinskih podjetij v primerjavi z nedružinskimi. 



\section{Kakovost podjetniškega ekosistema}

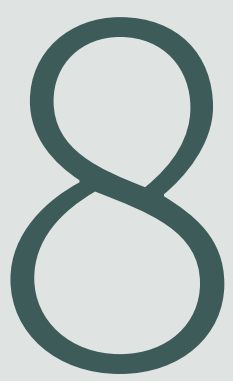

\section{Ključna spoznanja}

- Po vrednosti indeksa nacionalnega podjetniškega konteksta NECI, ki za Slovenijo znaša 4,6 (na lestvici od 0 do 10), smo tik pod evropskim in svetovnim povprečjem, nekoliko bolj pa zaostajamo, če se primerjamo s skupino najbolj razvitih, inovacijskih gospodarstev.

- Slovenski izvedenci najviše ocenjujejo dostop do razpoložljive fizične infrastrukture, dinamičnost notranjega trga ter kakovost poslovne in strokovne infrastrukture.

- Najniže v povprečju ostajajo ocenjeni izobraževanje in usposabljanje za podjetništvo na primarni in sekundarni ravni, vladne politike - tako v smislu regulative kot podpore ter prenos raziskav in razvoja.

- V primerjavi z letom poprej se je izboljšalo sedem okvirnih pogojev za podjetništvo, po oceni slovenskih izvedencev najbolj kulturne in družbene norme, kar je glede na prejšnja leta presenetljivo, izboljšale pa so se tudi ocene izobraževanja za podjetništvo na vseh ravneh.

- Najizrazitejše poslabšanje povprečne ocene v primerjavi z letom 2019 beležijo vladni programi za podjetništvo, predvsem zaradi števila vladnih programov za nova in rastoča podjetja.

- Mnenje izvedencev je, da se je podjetniški sektor v Sloveniji proaktivno odzval na zaprtje zaradi pandemije covida-19.

- Med zaviralnimi dejavniki za podjetništvo v Sloveniji se je največ odgovorov izvedencev ponovno nanašalo na regulativo vladnih politik, največ prednosti za spodbujanje podjetništva pa so prepoznali v zmogljivostih za podjetništvo. 
V okviru raziskave GEM ocenjujemo okolje za podjetja z opredelitvijo številnih podjetniških okvirnih pogojev, ki vplivajo na to, kako enostavno ali težko je ustanoviti novo podjetje in ga nato razviti v trajnostno uveljavljen posel. Okolje, v katerem živijo in delujejo podjetni posamezniki, namreč pomembno vpliva na njihovo odločitev, da ustanovijo podjetje ali razširijo že obstoječe poslovanje (Isenberg, 2010, 2011; Mason in Brown, 2014; Spigel, 2017; Stam in Spigel, 2018; Stam in van de Ven, 2019). Podjetniški ekosistem s tem predstavlja temeljno izhodišče za snovanje in izvajanje podjetniške politike $v$ mestih in regijah ali na ravni nacionalnega gospodarstva. Kot navajata Audretsch in Link (2012), skušajo oblikovalci politik prepoznati politične vzvode, s katerimi je mogoče spodbujati višjo raven podjetniške aktivnosti, ki se kaže v večji gospodarski rasti in ustvarjanju delovnih mest.

Ekosistem razumemo kot skupnost hierarhično neodvisnih, a hkrati soodvisnih heterogenih udeležencev, ki skupaj ustvarjajo rezultate ekosistema (Stam in Spigel, 2018). Pojem ekosistem sicer izhaja iz ekologije in se v poslovnih vedah nanaša na strukturo, kjer podjetja v različnih panogah delujejo kooperativno in konkurenčno, da bi zadovoljevali potrebe odjemalcev. Po Masonu in Brownu (2014) opredeljujemo podjetniški ekosistem kot »splet medsebojno povezanih podjetnikov (potencialnih in obstoječih), podjetniških podpornih organizacij (na primer skladov tveganega kapitala, poslovnih angelov, bank, podjetniških pospeševalnikov, univerzitetnih in podjetniških inkubatorjev ter tehnoloških parkov ...), javnih ustanov (na primer univerz, javnih raziskovalnih organizacij, javnih agencij in javnih skladov) in podjetniških procesov (kot je na primer stopnja nastajanja novih podjetij, število hitro rastočih podjetij, število serijskih podjetnikov, stopnja podjetniških ambicij ...), ki se formalno in neformalno povezujejo v nacionalnem podjetniškem okolju«. Udeleženci delujejo vsak v svoji specializirani vlogi, pa vendar so njihove vloge soodvisne $\checkmark$ smislu, da noben udeleženec ekosistema ne more ustvariti rezultata sam (Llewellyn in Autio, 2019). Seveda je podjetnik nedvomno osrednji akter v podjetniškem ekosistemu (Stam, 2015; Acs in drugi, 2017). Podjetniški ekosistemski pristop podjetništva namreč ne vidi le kot rezultat, temveč poudarja pomen podjetnikov kot osrednjih akterjev pri graditvi in ohranjanju zdravega sistema (Stam, 2015). Iz opredelitev in doslej razvitih modelov podjetniškega ekosistema pa je jasno, da morajo podjetnike ustrezno podpreti različni deležniki in zainteresirane strani, da bi se izboljševalo njihovo delovanje in ohranjala trajnost. Medsebojna interakcija in sinergija med javnimi in zasebnimi partnerji prispevata k postavitvi zdravih stebrov za razvoj podjetniške aktivnosti.

\subsection{Ocena okvirnih pogojev za podjetništvo}

V okviru raziskave GEM z anketiranjem odraslega prebivalstva (ang. adult population survey - APS) proučujemo in spremljamo stališča in dojemanje prebivalstva o podjetništvu in druge dejavnike, navedene $v$ 1. poglavju, podatke o kakovosti nacionalnih pogojev za podjetništvo pa pridobimo z anketiranjem nacionalnih izvedencev (ang. national expert survey - NES). To so podjetniki, managerji in drugi posamezniki iz gospodarstva, politike, državne uprave in akademske sfere, ki imajo izkušnje in znanje za delovanje na različnih področjih, povezanih s podjetništvom. Ta področja, ki oblikujejo kontekst, v katerem se odvija podjetniška aktivnost, v raziskavi imenujemo okvirni podjetniški pogoji in zajemajo podjetniške finance, vladne politike, vladne programe, izobraževanje za podjetništvo, prenos raziskav in razvoja, poslovno in strokovno infrastrukturo, dinamiko in odprtost notranjega trga, fizično infrastrukturo ter kulturne in družbene norme. Podrobneje jih predstavljamo v prilogi 2, na sliki 8.1 pa prikazujemo nekatere njihove ključne značilnosti v letu 2020. 
Slika 8.1: Ključne značilnosti po okvirnih pogojih za podjetništvo v letu 2020

1. Finančna podpora

2. Vladne politike - podpora

3. Vladne politike - regulativa

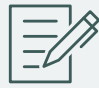

4. Vladni programi

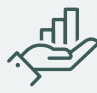

5. Podjetniško izobraževanje v OŠ in SŠ

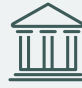

(€)
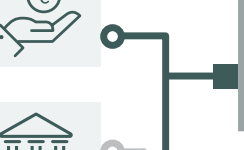

OKVIRNI PODJETNIŠKI POGOJI

so najmočnejši v visokodohodkovnih

gospodarstvih.
V SLOVENIJI SE JE V POVPREČJU IZBOLJŠALO $58 \%$ OKVIRNIH PODJETNIŠKIH POGOJEV V PRIMERJAVI S PRETEKLIM LETOM. NAJBOLJ:

- kulturne in družbene norme

- podjetniško izobraževanje

\section{PODJETNIŠKO IZOBRAŽEVANJE} VOŠ IN SŠ

ostaja najšibkejši indikator v vseh $\quad<4$

gospodarstvih, s povprečno oceno

3,31 v Sloveniji (na lestvici od 0 do 10).

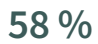

ถูกิก์

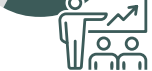

6. Podjetniško izobraževanje in usposabljanje po SŠ

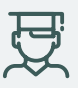

7. Prenos raziskav in razvoja

8. Poslovna in strokovna infrastruktura

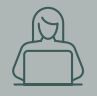

9. Notranji trg-dinamičnost
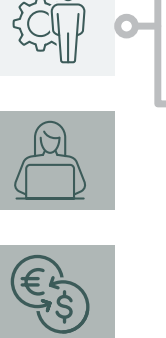

10. Notranji trg - odprtost, bremena

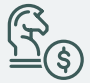

11. Fizična infrastruktura

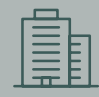

12. Kulturne in družbene norme

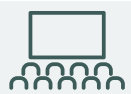

\section{NIZKE OCENE V SLOVENIJI \\ BELEŽIJO TUDI: \\ - vladne politike \\ - prenos R\&R}

\section{VLADNIM PROGRAMOM}

se je povprečna ocena $v$ primerjavi

z letom poprej najbolj poslabšala.
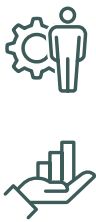

FIZIČNA INFRASTRUKTURA

ostaja najbolj pozitivna komponenta ekosistema, s s povprečno oceno 6,81 v Sloveniji.

POZITIVNO RANGIRANJE pa beležita tudi:

$>6$

- dinamičnost notranjega trga

- poslovna in strokovna infrastruktura

GEM Slovenija 2020, NES

Da bi ugotovili te značilnosti, so izvedenci po vseh okvirnih pogojih s pomočjo Likertove lestvice od 0 (zelo nezadovoljivo) do 10 (zelo zadovoljivo) ocenili širok nabor izjav. Tako zbrani podatki so harmonizirani in ustrezno uteženi, z analizo zanesljivosti in metodo glavnih komponent pa se pridobi večdimenzionalna mera - skupna povprečna ocena posameznega okvirnega pogoja za podjetništvo na nacionalni ravni. V vsaki državi se v skladu z metodologijo zberejo mnenja vsaj 
36 nacionalnih izvedencev, pri čemer je vzorec primerno utežen glede na devet okvirnih pogojev za podjetništvo, tip izvedenca, spol, sektor gospodarstva in geografsko porazdelitev. Anketiranje je v Sloveniji potekalo maja in junija 2020. Upoštevani so bili zadostno izpolnjeni vprašalniki (vsaj 75 \% podanih odgovorov). Tipična rotacija je bila tudi v letu 2020 vsaj $25 \%$ novih izvedencev, da bi zmanjšali pristranskost in zagotovili objektivnost. Z ocenjevanjem enakih trditev v vseh državah pa je zagotovljena tudi mednarodna primerljivost rezultatov. Dodatna metodološka pojasnila in informacije o podatkovnih podlagah je mogoče najti tudi v 1. poglavju te monografije, opis značilnosti vzorca slovenskih izvedencev sodelujočih v letu 2020 pa v prilogi 1.

Med vsemi ocenjenimi podjetniškimi okviri v Sloveniji ima, tako kot ževsa leta doslej, najvišjo oceno razpoložljiva fizična infrastruktura. Temu podjetniškemu pogoju s povprečnimi ocenami nad 5 ( 5 = niti res niti narobe; ocene nad 5 pomenijo pozitivno rangiranje, ocene pod 5 pa negativno) sledijo dinamičnost notranjega trga ter kakovost poslovne in strokovne infrastrukture, ki jo potrebujejo nova in rastoča podjetja (lastninske pravice, poslovna infrastruktura, računovodske, pravne in druge storitve). V primerjavi z letom 2019 se je izboljšalo kar sedem okvirnih pogojev za podjetništvo, po oceni izvedencev najbolj, presenetljivo, kulturne in družbene norme, za katere so bile sicer vrsto let zabeležene zelo nizke povprečne ocene, izrazito pod povprečjem skupine evropskih držav, sodelujočih v raziskavi GEM. Temu sledi postopno izboljšanje izobraževanja za podjetništvo na vseh ravneh, kar nekoliko kaže tudi na razmeroma dobro obvladovanje izzivov večmesečnega zaprtja izobraževalnih ustanov v času pandemije. Pri vseh teh ocenah pa moramo ves čas upoštevati, da se je anketiranje zaključilo konec junija, ko posledice pandemije še niso bile izražene v polni meri.

Podjetnik ali podjetniški tim je vselej $v$ tesni interakciji ne le z gospodarskim, temveč tudi s kulturnim in družbenim okoljem, ki vpliva na njegove/njihove podjetniške odločitve in jih sooblikuje. Ob tem, da izvedenci dobro ocenjujejo infrastrukturo za podjetništvo v Sloveniji, je mogoče zaslediti tudi postopno izboljšanje naklonjenosti podjetništvu in podjetniških vrednot, kar je rezultat podjetniškega izobraževanja, ozaveščanja javnosti o vlogi in pomenu podjetništva, promocije podjetniških zgodb v medijih, dobrih zgledov, primerov dobre prakse na tekmovanjih, natečajih, konferencah in drugih projektih, povezanih s podjetništvom. Že v 3. poglavju smo ugotovili, da ljudje v Sloveniji menijo, da je podjetništvo dobra izbira kariere, da slovenska družba spoštuje in priznava zahtevnost podjetniškega poklica in ga nagrajuje z visoko stopnjo družbenega spoštovanja ter da je v medijih mogoče zaznati visoko stopnjo podpore podjetništvu. Podrobnejšo analizo okvira kulturnih in družbenih norm predstavljamo v podpoglavju 8.1.4.

Najizrazitejše poslabšanje povprečne ocene v primerjavi z letom 2019 je zabeleženo pri vladnih programih za podjetništvo (s povprečno oceno 5,13 v letu 2019 in znižanjem na 4,47 v letu 2020). Okvirni pogoji za podjetništvo, ki so v Sloveniji najslabše ocenjeni, so sicer še naprej enaki kot že nekaj let zapored; to so izobraževanje za podjetništvo na primarni in sekundarni ravni, vladne politike in nezadosten obseg, $v$ katerem nacionalne raziskave in razvoj vodijo do novih poslovnih priložnosti in so na voljo MSP (obstoj in učinkovitost različnih mehanizmov za prenos raziskovalnih dosežkov in tehnologije z univerz in iz raziskovalnih centrov v podjetniško prakso). 
Slika 8.2: Povprečne ocene okvirnih pogojev za podjetništvo v Sloveniji primerjalno s povprečjem evropskih držav in vseh držav GEM

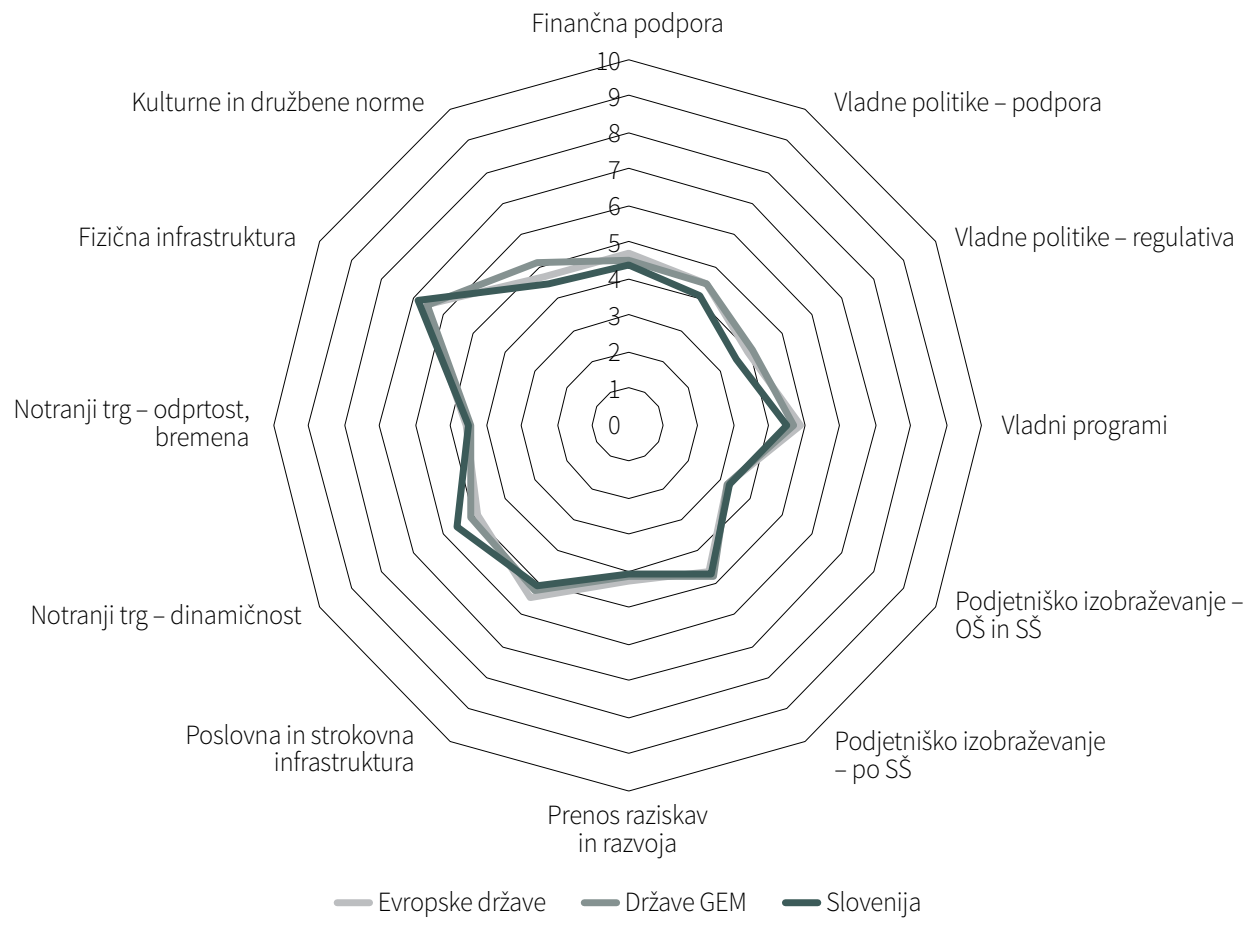

Tehtano povprečje, 0 = zelo nezadovoljivo, 10 = zelo zadovoljivo

\begin{tabular}{|l|r|r|r|r|r|r|}
\hline & $\begin{array}{r}\text { Finančna } \\
\text { podpora }\end{array}$ & $\begin{array}{r}\text { Vladne } \\
\text { politike- } \\
\text { podpora }\end{array}$ & $\begin{array}{r}\text { Vladne } \\
\text { politike- } \\
\text { regulativa }\end{array}$ & $\begin{array}{r}\text { Vladni } \\
\text { programi }\end{array}$ & $\begin{array}{r}\text { Podjetniško } \\
\text { izobraževanje - } \\
\text { OŠ in SŠ }\end{array}$ & $\begin{array}{r}\text { Podjetniško } \\
\text { izobraževanje - } \\
\text { po SŠ }\end{array}$ \\
\hline Slovenija & 4,41 & 4,08 & 3,56 & 4,47 & 3,31 & 4,73 \\
\hline $\begin{array}{l}\text { Povprečje } \\
\text { evropskih držav }\end{array}$ & 4,70 & 4,44 & 3,95 & 4,87 & 3,28 & 4,64 \\
\hline $\begin{array}{l}\text { Povprečje } \\
\text { držav GEM }\end{array}$ & 4,50 & 4,49 & 4,05 & 4,70 & 3,24 & 4,79 \\
\hline & $\begin{array}{r}\text { Prenos } \\
\text { raziskav in } \\
\text { razvoja }\end{array}$ & $\begin{array}{r}\text { Poslovna in } \\
\text { infrastruktura }\end{array}$ & Notranji trg- & $\begin{array}{r}\text { Notranji trg- } \\
\text { odprtost, } \\
\text { dremena }\end{array}$ & $\begin{array}{r}\text { Fizična } \\
\text { infrastruktura }\end{array}$ & $\begin{array}{r}\text { Kulturne in } \\
\text { družbene } \\
\text { norme }\end{array}$ \\
\hline Slovenija & 4,09 & 5,10 & 5,59 & 4,50 & 6,81 & 4,48 \\
\hline $\begin{array}{l}\text { Povprečje } \\
\text { evropskih držav }\end{array}$ & 4,27 & 5,46 & 4,88 & 4,55 & 6,60 & 4,67 \\
\hline $\begin{array}{l}\text { Povprečje } \\
\text { držav GEM }\end{array}$ & 4,13 & 5,24 & 5,12 & 4,40 & 6,52 & 5,15 \\
\hline
\end{tabular}

GEM Slovenija 2020, NES

Primerjava povprečnih ocen okvirnih pogojev za podjetništvo z evropskimi državami GEM in vsemi sodelujočimi državami (slika 8.2) kaže, da se Slovenija v letu 2020 nad povprečje Evrope uvršča pri štirih okvirnih pogojih, najizraziteje pri dinamičnosti notranjega trga in fizični infrastrukturi. 
Pri teh dveh okvirnih pogojih beležimo tudi višje povprečje ocene, kot to velja za skupino vseh sodelujočih držav GEM.

Najbolj pod povprečjem evropskih držav pa so slovenski izvedenci ocenili vladne programe, pri katerih je bil v primerjavi z letom 2019 zabeležen največji padec v povprečni oceni okvirnih pogojev za podjetništvo $v$ Sloveniji. Temu sledi kritična ocena vladne politike $\vee$ smislu regulative (davki in birokracija), pa tudi podpore. Pri teh okvirnih pogojih smo izraziteje tudi pod povprečjem ocen vseh sodelujočih držav GEM. Čeprav so ocene profesionalne in strokovne infrastrukture v Sloveniji pozitivno rangirane, pa primerjava z Evropo pokaže, da so tudi na tem področju še možne izboljšave, enako velja za podjetniške finance. Spodbudno pa je, da smo se v letu 2020 glede na povprečne ocene izvedencev evropskemu povprečju približali oziroma ga celo presegli pri podjetniškem izobraževanju, pa tudi, kot smo že omenili, pri kulturnih in družbenih normah, kar so bili vrsto let okvirni pogoji za podjetništvo, pri katerih smo za Evropo zaostajali.

\subsubsection{Vladne politike}

V sodobnih tržnih gospodarstvih vladne politike in pobude pomembno sooblikujejo pogoje, ki spodbujajo podjetniški potencial. V okviru raziskave GEM okvir vladnih politik delimo na del, ki se nanaša na podporo (prve tri trditve), in del, ki se nanaša na regulativo (zadnje štiri trditve), in je okvir, ki je z vidika izvedencev že vrsto let zapored ocenjen zelo kritično.

Slika 8.3: Ocene elementov vladnih politik v Sloveniji in evropskih državah (tehtano povprečje, 0 = zelo nezadovoljivo, 10 = zelo zadovoljivo)

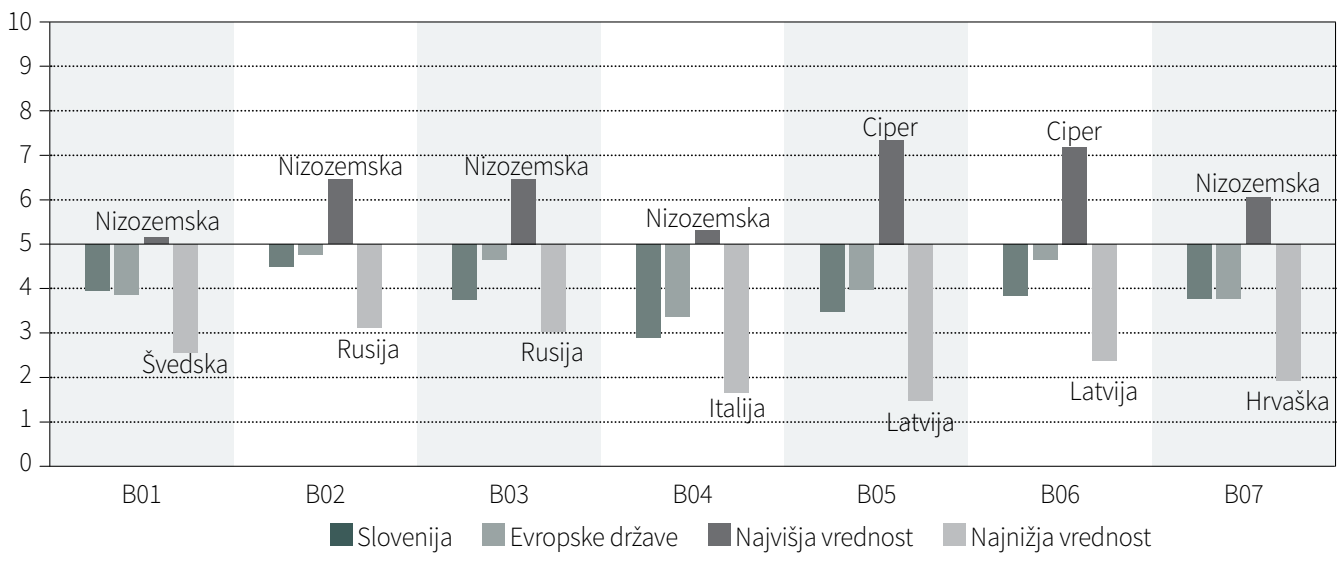

Legenda:

V Sloveniji ...

B01 državne politike (na primer javni razpisi, zakonodaja, regulativa, izdajanje dovoljenj, obdavčenje) dosledno favorizirajo nova podjetja.

B02 je podpora za nova in rastoča podjetja velika prioriteta politike na državni ravni.

B03 je podpora za nova in rastoča podjetja velika prioriteta politike v občinah in upravnih enotah.

B04 lahko nova podjetja dobijo večino potrebnih dovoljenj in koncesij v približno tednu dni.

B05 višina davkov NE predstavlja bremena za nova in rastoča podjetja.

B06 se davčna in druga vladna regulativa za nova in rastoča podjetja uporablja na predvidljiv in konsistenten način.

B07 spopadanje z državno birokracijo in regulativo ter pridobivanje potrebnih dovoljenj za poslovanje za nova in rastoča podjetja ni pretirano težavno. 
Rezultati kažejo (slika 8.3), da se nadaljuje trend negativnega rangiranja elementov vladnih politik tako v Sloveniji kot tudi na ravni evropskih držav (povprečne ocene pod 5). V letu 2020 so bili slovenski izvedenci ponovno najbolj kritični do hitrosti pridobivanja potrebnih dovoljenj in koncesij (povprečna ocena 2,88 na lestvici od 0 do 10). Najvišja povprečna ocena v tem okviru je bila zabeležena za trditev, da je podpora za nova in rastoča podjetja velika prioriteta politike na državni ravni (povprečna ocena 4,49), primerjava z Evropo pa nas kljub temu uvršča pod povprečje. Najizraziteje pod povprečjem evropskih držav se znajdemo pri podpori za nova in rastoča podjetja na ravni občin in upravnih enot, temu sledi (ne)predvidljivost in (ne)konsistentnost davčne in druge vladne regulative za nova in rastoča podjetja. Zraven evropskega povprečja pa se uvrščamo pri favoriziranju novih podjetij s strani državne politike (na primer javni razpisi, zakonodaja, regulativa, izdajanje dovoljenj, obdavčenje) ter pri spopadanju z državno birokracijo, regulativo in pri pridobivanju potrebnih dovoljenj za poslovanje novih in rastočih podjetij. Povprečna ocena tega okvira je sicer še vedno nizka in v Sloveniji znaša 3,78. Najboljšo prakso pri spopadanju z birokracijo in regulativo po mnenju izvedencev med evropskimi državami predstavlja Nizozemska, ki je država s pogosto najvišjimi povprečnimi ocenami posameznih elementov v sklopu vladnih politik za podjetništvo.

Izvedenci vsako leto v sklopu anketiranja navedejo tudi tri področja, ki podjetništvo po njihovem mnenju najbolj zavirajo, tri prednosti za podjetništvo in tri priporočila za njegovo izboljšanje. Med zaviralnimi dejavniki se je največ odgovorov izvedencev ponovno nanašalo na vladne politike, pri čemer so kot že nekaj let zapored kot največji zaviralni dejavnik za podjetništvo v Sloveniji izpostavili administrativne ovire. Ta dejavnik bi tudi po Poročilu o razvoju (UMAR, 2020c) lahko imel v prihodnje ob vse hitrejši dinamiki uvajanja novih proizvodov in storitev še večji negativni vpliv na investicijsko aktivnost podjetij kot pred leti. Izvajanje programa ukrepov za odpravo administrativnih ovir in priprave boljših predpisov se sicer zagotavlja s stalnim izvajanjem projekta STOP birokraciji, vendar kljub več kot desetletnemu sistematičnemu odpravljanju ovir po mnenju izvedencev očitno premalo učinkovito. Pomembnejši sprejeti ukrepi v zadnjih letih posegajo tudi na področje podjetništva, na primer test MSP, vzpostavitev Slovenske poslovne točke - sistem SPOT, izboljšanje dostopnosti finančnih virov za zagonska podjetja, svetovanje prek vavčerjev in podobno (UMAR, 2020c). V oceni napredka pri strukturnih reformah, preprečevanju in odpravljanju makroekonomskih neravnotežij ter rezultatov poglobljenih pregledov (Evropska komisija, 2020) je navedeno, da se regulativno breme v Sloveniji postopoma zmanjšuje, vendar je na nekaterih področjih še vedno razmeroma veliko. Podjetniki še vedno opozarjajo, da so pogoste nepredvidene spremembe zakonodaje v Sloveniji za poslovno okolje moteče. Poleg tega je upravno breme za MSP veliko in se zmanjšuje prepočasi. Nezadovoljstvu s preveč birokracije se tesno priključuje tudi nestimulativna davčna politika, še posebej za nastajajoča podjetja, in učinkovitost delovanja državnih inštitucij.

Okvir vladnih politik na področju regulative je že vsa leta ocenjen niže, kot to velja za vidik podpore. Vendar pa med državami članicami EU vladno podporo za podjetništvo više od slovenskih izvedencev $\vee$ povprečju ocenjujejo izvedenci v vseh sodelujočih evropskih državah razen na Hrvaškem, Švedskem in Slovaškem. 


\subsubsection{Vladni programi}

Skupna povprečna ocena vladnih programov za podjetništvo v Sloveniji se je glede na preteklo leto poslabšala predvsem na račun števila vladnih programov za nova in rastoča podjetja.

Slika 8.4: Ocene elementov vladnih programov v Sloveniji in evropskih državah (tehtano povprečje, 0 = zelo nezadovoljivo, 10 = zelo zadovoljivo)

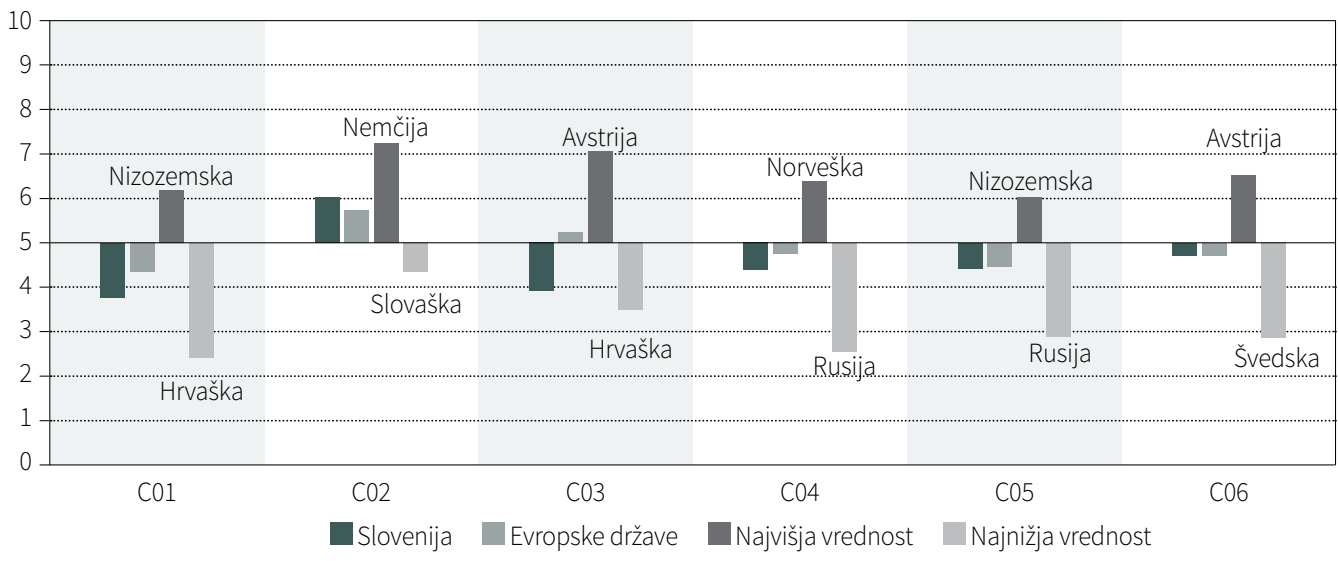

Legenda

VSloveniji...

C01 lahko nova in rastoča podjetja pridobijo različne vrste vladne podpore pri eni agenciji, na enem mestu.

C02 znanstveni parki in poslovni inkubatorji zagotavljajo učinkovito podporo za nova in rastoča podjetja.

C03 imamo primerno število vladnih programov za nova in rastoča podjetja.

C04 so ljudje, ki delajo za vladne institucije, strokovno usposobljeni in uspešni pri podpiranju novih in rastočih podjetij.

C05 lahko skorajda vsak, ki potrebuje pomoč od vladnih programov za nova in rastoča podjetja, najde, kar potrebuje.

C06 so vladni programi, ki podpirajo nova in rastoča podjetja, uspešni.

GEM Slovenija 2020, NES

S povprečno oceno 6,03 (na lestvici od 0 do 10) se izvedenci strinjajo, da v Sloveniji znanstveni parki in poslovni inkubatorji zagotavljajo učinkovito podporo za nova in rastoča podjetja, kar je višja ocena kot leto poprej in s katero se uvrščamo nad povprečje ocen izvedencev evropskih držav. Najvišje ocene so si v letu 2020 pri tej trditvi prislužile Nemčija, Nizozemska in Švica. Tik zraven Evrope smo pri oceni uspešnosti vladnih programov, ki podpirajo nova in rastoča podjetja, najbolj pod povprečjem evropskih držav pa pri oceni števila vladnih programov za nova in rastoča podjetja. Pri slednjem beležimo tudi največje poslabšanje povprečne ocene v primerjavi z letom poprej. Najvišjo oceno med evropskimi državami glede primernega števila vladnih programov za nova in rastoča podjetja je sicer zabeležila Avstrija.

Posledice pandemije covida-19 so vplivale na dogajanje po vsem svetu in s tem tudi na izvajanje nekaterih vladnih aktivnosti. Kratkoročno so bila absolutna prednostna naloga ukrepi za podporo delovanju zdravstvenega sistema, na gospodarskem področju pa ukrepi za blažitev posledic pandemije, ki bodo podprli podjetja in prebivalstvo pri premagovanju likvidnostnih težav zaradi izpada prihodkov in kar najbolj zagotovili ohranjanje delovnih mest in družbenih potencialov (UMAR, 2020c). V Spremembah programa dela in finančnega načrta za leti 2020 in 2021 agencija SPIRIT sicer navaja, da je $v$ teh dveh letih glavni poudarek na izvajanju obstoječih projektov in 
programov ter zagotavljanju nemotenega izvajanja novih projektov, pa tudi projektov SPOT in trajnostni poslovni modeli (SPIRIT, 2020).

Slovenski izvedenci med zaviralnimi dejavniki za podjetništvo $\vee$ okviru vladnih programov najpogosteje izpostavljajo nekonsistentnost podpornih ukrepov, razpršenost sredstev po različnih deležnikih podpornega okolja, netransparentnost in neusklajenost med deležniki. Spodbudno za podjetništvo v tem okviru pa so prepoznali učinkovito podporno mrežo na regionalni in lokalni ravni (mreža Subjektov inovativnega okolja (SIO), SPOT točke, delovanje Obrtne in Gospodarske zbornice, regionalnih razvojnih agencij) ter bottom-up iniciativ, kot je Iniciativa Start:up Slovenija kot aktivna povezovalka in promotorka javnih in zasebnih deležnikov slovenskega startup ekosistema.

\subsubsection{Poslovna in strokovna infrastruktura}

Poslovna in strokovna infrastruktura za podjetništvo je okvir, pri katerem so kar tri trditve od petih rangirane pozitivno (s povprečnimi ocenami nad 5), kar pomeni, da se izvedenci z njimi strinjajo. Te trditve so: da je v Sloveniji dovolj kooperantov, dobaviteljev in svetovalcev, ki podpirajo nova in rastoča podjetja, da nova in rastoča podjetja z lahkoto pridobijo dobre in strokovne pravne in računovodske storitve ter tudi dobre bančne storitve (transakcijski računi, plačilni promet s tujino, kreditne garancije in podobno). Podrobnejši vpogled in primerjava z evropskimi državami pa kljub temu kaže na precejšnje rezerve, saj so vsi elementi v tem okviru, kljub visokim ocenam, pod povprečjem evropskih držav.

Slika 8.5: Ocene elementov poslovne in strokovne infrastrukture v Sloveniji in evropskih državah (tehtano povprečje, 0 = zelo nezadovoljivo, 10 = zelo zadovoljivo)

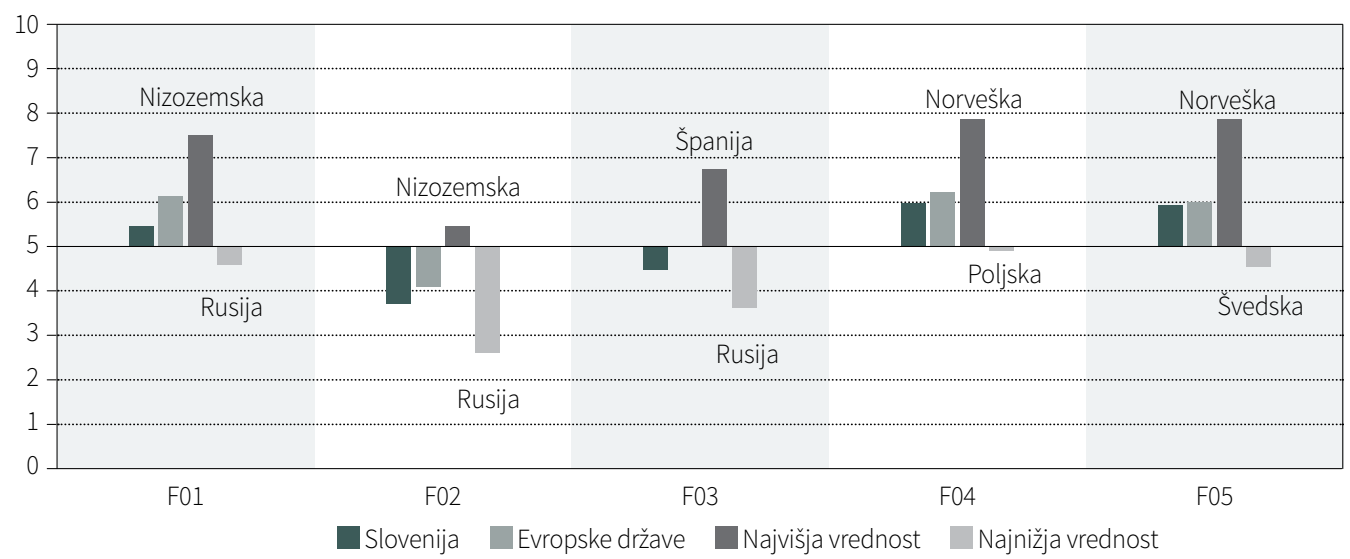

Legenda

vSloveniji ...

F01 je dovolj kooperantov, dobaviteljev in svetovalcev, ki podpirajo nova in rastoča podjetja.

F02 nova in rastoča podjetja zmorejo kriti stroške uporabe kooperantov, dobaviteljev in svetovalcev.

F03 nova in rastoča podjetja z lahkoto najdejo dobre kooperante, dobavitelje in svetovalce.

F04 nova in rastoča podjetja z lahkoto pridobijo dobre in strokovne pravne in računovodske storitve.

F05 nova in rastoča podjetja z lahkoto pridobijo dobre bančne storitve (transakcijski računi, plačilni promet s tujino, kreditne garancije in podobno). 
Po mnenju izvedencev v okviru poslovne in strokovne infrastrukture najbolj zaostajamo za Evropo ravno pri številu kooperantov, dobaviteljev in svetovalcev ter pri njihovi dostopnosti. V Sloveniji je praviloma teh dovolj, vendar pa podjetniki le s težavo najdejo kvalitetne. Najvišjo oceno med evropskimi državami ima pri tej trditvi Španija. Evropskemu povprečju se najbolj približamo pri pridobivanju bančnih storitev (transakcijski računi, plačilni promet s tujino, kreditne garancije in podobno).

Izvedenci med spodbudnimi dejavniki za podjetništvo v Sloveniji na tem področju najpogosteje izpostavljajo kvalitetno mentorsko podporo za startup podjetja, pa tudi digitalizacijo javnega sektorja. Slovenija je namreč sprejela ukrepe za zmanjšanje stroškov zagotavljanja skladnosti s predpisi, zlasti s spodbujanjem e-postopkov in e-storitev (Evropska komisija, 2020), vendar pa po oceni UMAR-ja digitalizirane javne storitve za podjetja še naprej ostajajo problematične (UMAR, 2020c).

\subsubsection{Kulturne in družbene norme}

V raziskavi GEM ugotavljamo, da $\vee$ Sloveniji raste delež ljudi, ki menijo, da je podjetništvo dobra izbira kariere, da se v vrh evropskih držav uvrščamo po deležu ljudi, ki menijo, da so uspešni podjetniki v slovenski družbi spoštovani in da je $v$ medijih pogosto mogoče zaslediti primere dobre podjetniške prakse. Kljub temu pa so slovenski izvedenci kulturne in družbene norme vsa leta ocenjevali zelo kritično. V letu 2020 je mogoče zaznati pozitiven premik skupne ocene tega okvirnega pogoja, na sliki 8.6 pa posamezne elemente tudi podrobneje razčlenjujemo.

Slika 8.6: Ocene elementov kulturnih in družbenih norm v Sloveniji in evropskih državah (tehtano povprečje, 0 = zelo nezadovoljivo, 10 = zelo zadovoljivo)

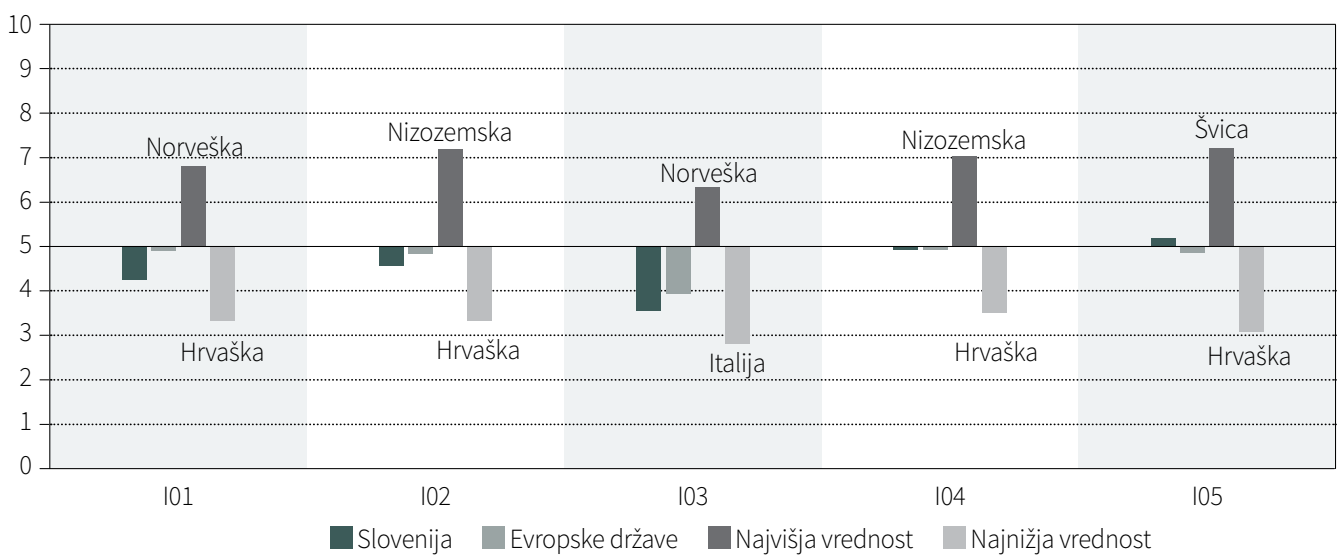

Legenda

V Sloveniji ...

101 nacionalna kultura močno podpira individualne uspehe, ki so bili doseženi z lastnimi napori.

102 nacionalna kultura poudarja neodvisnost, avtonomnost in osebno iniciativo.

I03 nacionalna kultura spodbuja podjetniško prevzemanje tveganja.

104 nacionalna kultura spodbuja ustvarjalnost in inovativnost.

105 nacionalna kultura poudarja odgovornost, ki jo ima posameznik (in ne skupnost) pri upravljanju svojega življenja. 
Slovenski izvedenci se najbolj strinjajo s trditvijo, da nacionalna kultura poudarja odgovornost, ki jo ima posameznik pri upravljanju svojega življenja (povprečna ocena 5,19 na lestvici od 0 do 10). Pri tej trditvi smo tudi nad evropskim povprečjem. V primerjavi z letom 2019 se nam je ocena $\vee$ tem okviru najbolj zvišala pri trditvi, da nacionalna kultura podpira individualne uspehe, ki so bili doseženi z lastnimi napori, čeprav smo primerjalno z evropskimi državami ravno pri tej trditvi še zmeraj najbolj pod povprečjem.

Kulturne in družbene norme so se torej v času krize zaradi covida-19 vendarle izkazale za bolj naklonjene podjetništvu kot pred njo, je pa na tem področju zagotovo še veliko izzivov in zaviralnih dejavnikov. Slovenski izvedenci jih vidijo v še vedno prepogosto slabšalnem odnosu do poslovnega uspeha, v enačenju podjetniške aktivnosti z akumuliranjem dobička in v tem, da ljudje ne zaznavajo vloge podjetnikov pri zagotavljanju novih delovnih mest in prispevku k razvoju ožje in širše skupnosti. Prav tako se tudi preveč stigmatizirajo podjetniki in podjetnice, ki so doživeli poslovne neuspehe. Po mnenju izvedencev je torej še vedno premalo ozaveščanja o pomenu podjetništva, sprejemanja drugačnosti in uspeha, kakor tudi razumevanja, da je podjetništvo tvegana dejavnost in da zato ne more uspeti prav vsak podjetniški poskus.

\subsection{Indeks nacionalnega podjetniškega konteksta (NECI)}

Raziskava GEM že od začetka opozarja na potrebo po spodbujanju podjetniških vrednot in podjetniškega izobraževanja. Rezultati se po dvajsetih letih skoraj niso spremenili in zelo malo držav se je dejansko zavezalo k izboljšanju tega stebra, ki ima v večini držav zelo nizke ocene in kar posledično vpliva tudi na nižjo povprečno oceno nacionalnega podjetniškega okolja. Brezposelnost mladih je $v$ mnogih državah izrazita, ker se veliko otrok in mladostnikov ni izobraževalo za podjetništvo in ni usvojilo miselnosti, da bi lahko sami ali v skupinah ustvarili lastno poklicno življenje, ki vodi k ustvarjanju delovnih mest tudi za druge. V razmerah, kot je sedanja pandemija covida-19, je podjetništvo mogoče ponovno videti kot del rešitve iz krize. Vendar bi bilo v izjemno zahtevnem tržnem okolju, ki ga zaradi zdravstvene krize pestijo številne omejitve, poleg podjetniškega usposabljanja treba okrepiti komponento ustvarjalnosti in inovativnosti ter obvladovanja novih tehnologij. $V$ državah, ki so se zavezale podjetniškemu izobraževanju in usposabljanju, bodo mladi razvili učinkovitejša orodja pri soočanju s trenutno gospodarsko krizo. Vsekakor pa je za razumevanje podjetniškega sektorja v vsaki posamezni državi potrebna najprej natančna analiza razmer in razvoja v okolju.

Indeks NECI (ang. national entrepreneurship context index) podaja oceno okolja za podjetništvo v nacionalnem gospodarstvu in ga v okviru raziskave GEM spremljamo od leta 2018. Lastnik novega poslovnega podjema v izredno podpornem okolju za podjetništvo bistveno hitreje in laže realizira aspiracije po rasti in popelje podjetje iz novega v ustaljeno. Indeks NECI daje oblikovalcem politik vpogled v to, kako takšno okolje spodbuditi.

Tudi tokrat je treba lestvice interpretirati ob upoštevanju njihovih prednosti in omejitev. Pomembno je vedeti, ali se kontekst izboljšuje ali slabša in kateri so najmočnejši in najšibkejši stebri oziroma okvirni podjetniški pogoji. Podatki so pomembni tudi zato, ker odražajo stanje podjetniškega okolja v času prvih omejitev in v prvem valu epidemije do poletja 2020.

Na lestvici NECI med 44 sodelujočimi državami $v$ tem delu raziskave prva tri mesta zasedajo Indonezija, Nizozemska in Tajvan. Slovenija si z oceno 4,6, kar je višja ocena kot leto poprej, deli 15. mesto skupaj s Kolumbijo in Latvijo. 
Slika 8.7: Indeks NECI 2020 po državah

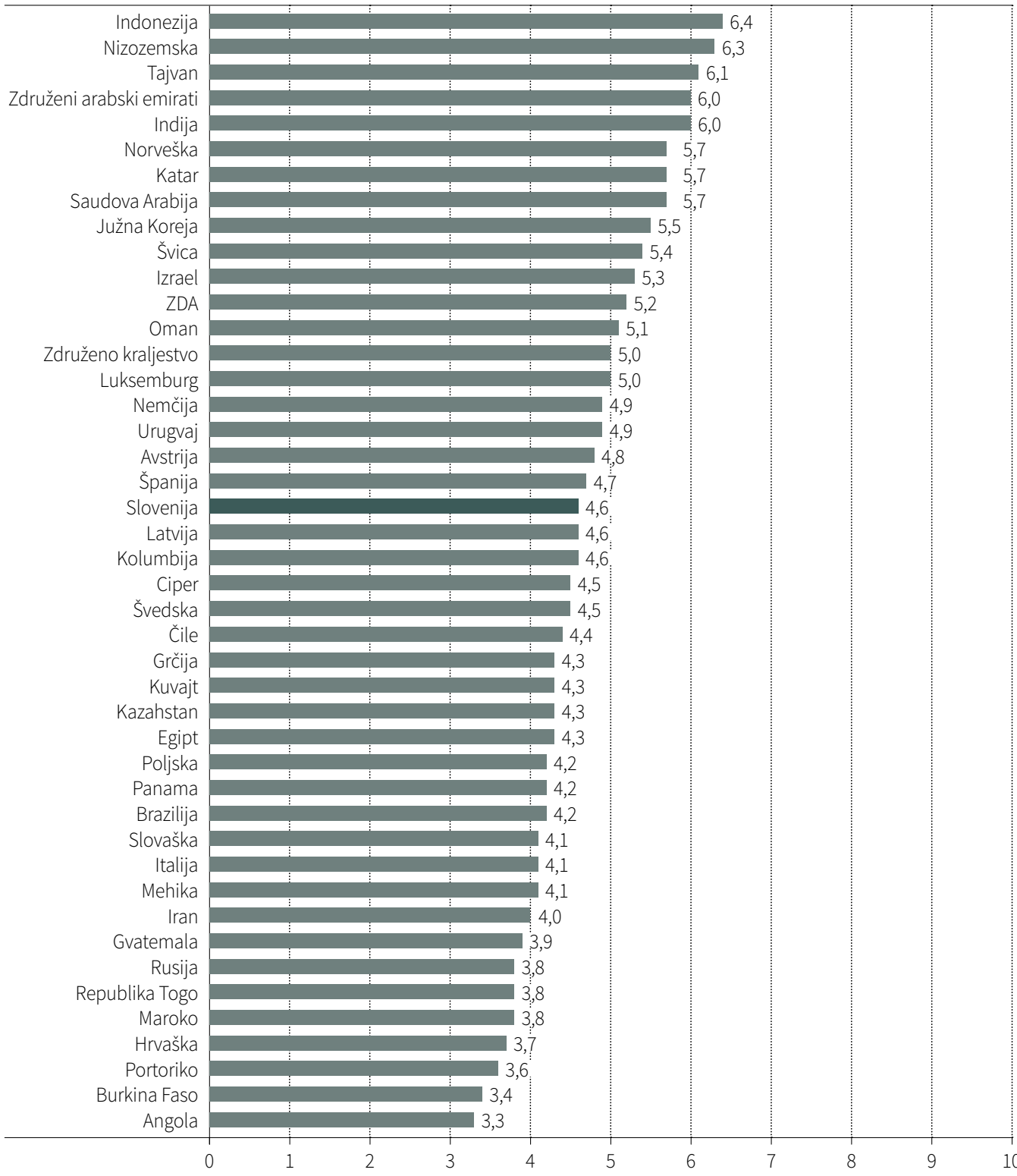

Evropske države so tako na vrhu kot tudi na repu lestvice, prav tako je na vseh treh stopnjah (v nizko-, srednje- in visokodohodkovnih gospodarstvih) mogoče najti države z visoko in nizko vrednostjo indeksa NECl. To je posledica zapletenosti in kompleksnosti podjetniškega fenomena in velikega števila spremenljivk, ki pogojujejo tak rezultat, na primer stopnja razvitosti držav, stopnja javne in zasebne zaposlenosti, kakovost podjetniške aktivnosti (iz nuje ali priložnosti), stanje podjetniških pogojev in podobno. Še zmeraj pa velja, da v povprečju višja vrednost indeksa $\mathrm{NECl}$ prevladuje $v$ visokodohodkovnih gospodarstvih. So pa sicer povprečne vrednosti indeksa NECI v letu 2020, splošno gledano, nizke. Rezultati tudi nakazujejo, da so evropski, ameriški in latinskoameriški podjetniki zaradi pandemije utrpeli občutno negativen vpliv, medtem ko so bili 


\section{Metodologija NECI}

Najmanj 36 nacionalnih izvedencev v vsaki državi, ki sodeluje v raziskavi GEM, kar zajema podjetnike in vse tiste, ki so na različnih področjih vključeni $v$ podjetništvo, je ocenilo vrsto komponent oziroma trditev $v$ vsakem od 12 okvirnih pogojev za podjetništvo na lestvici od 0 = zelo nezadovoljivo do 10 = zelo zadovoljivo. Na osnovi odgovorov vseh ekspertov iz vseh sodelujočih držav se z metodo glavnih komponent definira 12 uteženih konstruktov oziroma spremenljivk za 12 okvirjev. Enostavna aritmetična sredina tako dobljenih vrednosti novih spremenljivk za posamezno državo predstavlja vrednost NECI, kar omogoča rangiranje držav.

(Bosma et al., 2020)

azijski trgi na splošno manj prizadeti. Slednji so - kot rezultat globalizacije - postali pomemben dobavitelj osnovnih izdelkov in tehnologij v svet (GEM NES-NECI, 2021).

Slovenija je primerjalno z drugimi državami po vrednosti indeksa NECI tik pod evropskim in svetovnim povprečjem (povprečna vrednost NECI za Evropo je 4,7 in je enaka tudi za vse države, sodelujoče v raziskavi GEM). Nekoliko izraziteje pa zaostajamo, če se po vrednosti indeksa NECI primerjamo z visokodohodkovnimi gospodarstvi (povprečna ocena 4,9). Primerjava vrednosti NECl za leti 2019 in 2020 sicer kaže, da se okvirni pogoji za podjetništvo v večini držav niso bistveno spremenili, torej vpliv gospodarske krize zaradi pandemije še ni bil v celoti zajet. Kakšni bodo vplivi krize zaradi covida-19 na okvirne podjetniške pogoje, bo tako bolj jasno ob meritvah leta 2021.

Slika 8.8: Vrednosti indeksa NECI po skupinah držav

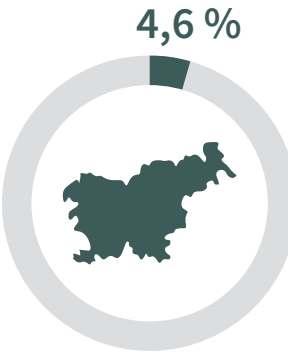

Slovenija

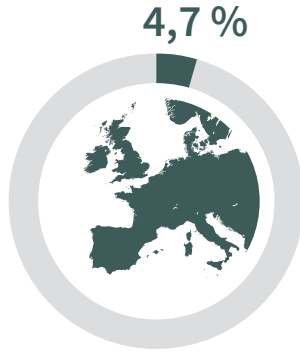

Evropa

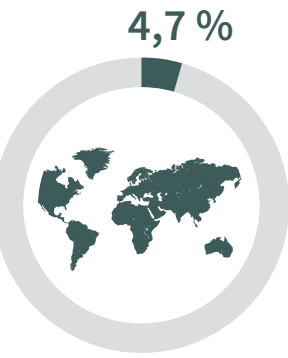

Države GEM

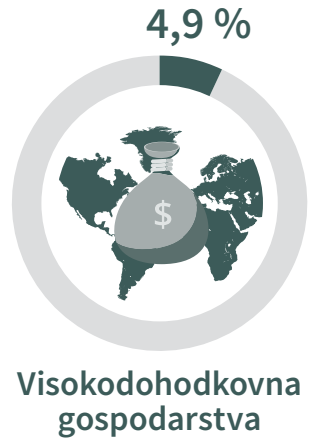

gospodarstva

GEM Slovenija 2020, NES

Rezultati tega dela raziskave GEM opozarjajo na pomen ugodnega nacionalnega konteksta za spodbujanje podjetništva po posameznih okvirnih pogojih, ki smo jih za Slovenijo podrobneje predstavili že v prejšnjih poglavjih. Vsaka posamezna država mora pri tem upoštevati, kolikšna stopnja podjetniške aktivnosti ustreza njeni gospodarski strukturi in da kakovost šteje več kot količina. Ključ do dobre diagnoze podjetniškega okolja je analiza stanja okvirnih pogojev v vsaki državi, prikaz povprečnega rezultata v smislu indeksa $\mathrm{NECl}$ in proučitev ocen elementov, ki sestavljajo posamezne okvirne pogoje za podjetništvo. Na ta način pridobimo relevantne informacije o vidikih, ki jih je v posameznem okviru mogoče izboljšati. 


\subsection{Zgodnji vpliv in učinek pandemije covida-19 za nova in rastoča podjetja}

Leto 2020 je bilo zaradi pandemije covida-19 izjemno leto po vsem svetu. Pandemija v kombinaciji s strogimi zdravstvenimi in zaščitnimi ukrepi pomeni velik negativen šok za gospodarsko aktivnost $\checkmark$ Sloveniji, v drugih evropskih državah in na globalni ravni. Začetek gospodarskega okrevanja pa bo ključno odvisen od hitrosti uvedbe, obsega in vsebine ukrepov ekonomskih politik v Sloveniji in drugih državah (UMAR, 2020d). Razmah epidemije v sosednji Italiji in širjenje koronavirusa SARS-Cov-2 v preostale evropske države sta v marcu 2020 zahtevala nujne in obsežne ukrepe za zaščito zdravja in ljudi v Sloveniji in v drugih evropskih državah. Obvladovanja situacije in dolgoročnega zmanjševanja škodljivih posledic za gospodarstvo in prebivalstvo se je slovenska vlada lotila s takojšnjimi interventnimi ukrepi, ki jih je mogoče implementirati v kratkem času, ter z oblikovanjem strateških ukrepov za pomoč prebivalstvu in gospodarstvu (GOV, 2021).

Ker je pandemija covida-19 sovpadala z začetkom zbiranja podatkov za nov cikel raziskave, smo v GEM-u razvili vrsto vprašanj, povezanih z vplivom pandemije na nova in rastoča podjetja. Nekaj vidikov in vplivov v povezavi s pandemijo covida-19 smo prikazali že v prejšnjih poglavjih te monografije, $v$ tem poglavju pa se osredotočamo predvsem na dva sklopa vprašanj, ki jih je v povezavi z učinki pandemije vključeval vprašalnik NES. Namen prvega sklopa je bil zajeti mnenje nacionalnih izvedencev o tem, kako se je podjetniški sektor odzval na zapiranje (tako imenovani lock-down) zaradi pandemije covida-19, namen drugega pa, da so izvedenci podali svoje mnenje o vladnih ukrepih za pomoč novim in rastočim podjetjem. Rezultati tako omogočajo zgodnji vpogled v spremembe, s katerimi se zaradi krize soočajo podjetniki.

Skupna povprečna ocena okvira, ki se nanaša na odziv podjetniškega sektorja na pandemijo, znaša 6,73 (na lestvici od 0 = zelo nezadovoljivo do 10 = zelo zadovoljivo), kar pomeni, da so se nova in rastoča podjetja $v$ Sloveniji, po mnenju nacionalnih izvedencev, proaktivno odzvala na zaprtje zaradi pandemije covida-19. Ocena nas uvršča v zgornjo polovico lestvice vseh sodelujočih držav GEM in nad povprečje Evrope. Povprečna ocena izvedencev iz evropskih držav v tem okviru znaša 6,46. Podrobnejši prikaz tega sklopa po posameznih vprašanjih prikazujemo na sliki 8.9.

Po mnenju nacionalnih izvedencev so se v Evropi številna nova in rastoča podjetja hitro prilagodila novim razmeram, ki so posledica pandemije (sprejela so nove načine poslovanja, spodbujala delo od doma, prilagodila svoje izdelke in storitve, odkrila nove poslovne priložnosti ipd.). V Sloveniji so izvedenci kar pet od šestih trditev tega sklopa ocenili s povprečnimi ocenami nad evropskim povprečjem. Trditvi, da zaradi pandemije covida-19 številna nova in rastoča podjetja odkrivajo mnogo novih priložnosti, pa so dodelili celo najvišjo povprečno oceno med vsemi evropskimi državami. Dejstvo je, da je kriza zaradi covida-19 nekaterim MSP-jem prinesla tudi nove priložnosti, čeprav so podjetniki pri tej trditvi nekoliko bolj zadržani. V sklopu anketiranja GEM APS namreč le 32,33\% zgodnjih podjetnikov meni, da je pandemija omogočila nove poslovne priložnosti, ki jih želijo v podjetju izkoristiti. S tem se Slovenija uvršča skoraj povsem na evropsko povprečje. Nekoliko pod povprečjem evropskih držav pa so slovenski izvedenci ocenili trditev, da se je v Sloveniji zaradi pandemije covida-19 povečalo sodelovanje med novimi, rastočimi in/ali uveljavljenimi podjetji. Trditev je, generalno gledano, ocenjena najniže, v Sloveniji s povprečno oceno 5,19 (na lestvici od 0 do 10). 
Slika 8.9: Ocene elementov reaktivacije in ponovne oživitve gospodarstva zaradi pandemije covida-19 v Sloveniji in evropskih državah (tehtano povprečje, 0 = zelo nezadovoljivo, $10=$ zelo zadovoljivo)

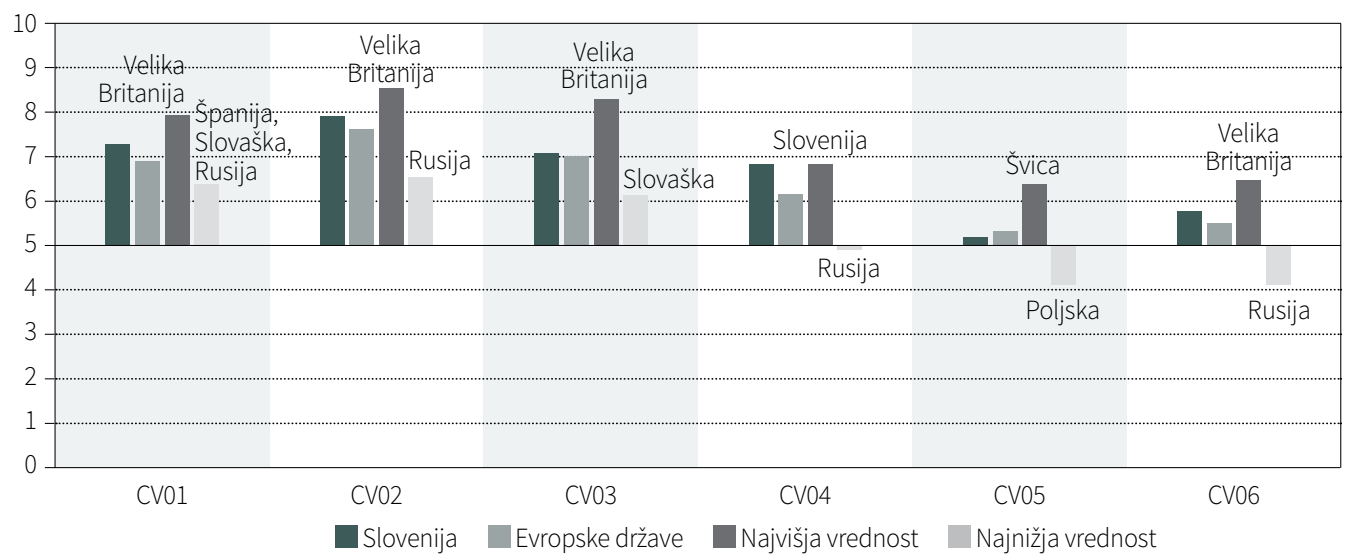

Legenda

VSloveniji ...

CV01 zaradi pandemije covida-19 številna nova in rastoča podjetja sprejemajo nove načine poslovanja.

CV02 zaradi pandemije covida-19 številna nova in rastoča podjetja spodbujajo delo od doma.

CV03 številna nova in rastoča podjetja spreminjajo svoje trenutne izdelke in storitve, da se prilagodijo pandemiji covida-19.

CV04 zaradi pandemije covida-19 številna nova in rastoča podjetja odkrivajo mnogo novih priložnosti.

CV05 zaradi pandemije covida-19 se je povečalo sodelovanje med novimi, rastočimi in/ali uveljavljenimi podjetji, kakor tudi znotraj njih. CV06 zaradi pandemije covida-19 številna nova in rastoča podjetja sodelujejo pri globalnih družbenih aktivnostih, izzivih in predlogih.

GEM Slovenija 2020, NES

Med izbruhom pandemije $\vee$ Sloveniji je največji upad $\vee$ poslovanju beležil storitveni sektor, predvsem turizem, pa tudi avtomobilska industrija, prevozništvo in industrijski sektor, skupaj z mediji in izobraževanjem (AmCham, Kearney, 2020). Na drugi strani pa se je povečala trgovina na drobno z osebno zaščitno opremo in izdelki za gospodinjstvo ter trgovina z izdelki in storitvami za prosti čas. Podjetja v omenjenih panogah so med izbruhom covida-19 beležila rast prodaje. Pozitiven učinek izbruha covida-19 je bilo mogoče zaznati tudi v IKT sektorju, saj so zasebne in javne ustanove za svoje zaposlene uvedle delo na daljavo. Po nekaterih raziskavah namerava več kot štiri petine podjetij pospešiti digitalizacijo notranjih procesov in ohraniti delo na daljavo, načrtujejo pa tudi robotizacijo procesov; večina teh podjetij prihaja iz storitvenega sektorja. Nekatera podjetja v Sloveniji povečujejo naložbe $v$ digitalizacijo, združitve in prevzeme ter razvijajo ukrepe prestrukturiranja poslovanja. Vedno večje število podjetij, zlasti v sektorju kemije in zdravstva, že razvija načrte prestrukturiranja svojih dejavnosti za obdobje po krizi. Skoraj polovica se pripravlja na notranje prestrukturiranje in tržne priložnosti ter pričakuje, da si bo država prizadevala za ohranitev enotnega evropskega trga (Economy snapshot - GEM COVID-19, 2020).

Kljub proaktivnemu odzivu podjetniškega sektorja pa so pri zgodnjih ukrepih vladnih politik za zajezitev posledic pandemije na področju gospodarstva zabeleženi slabši rezultati. Slovenski izvedenci so ta okvir ocenili s povprečno oceno 4,92 (na lestvici od 0 do 10), povprečje evropskih držav pa znaša 5,29. 
Večina izvedencev iz držav, sodelujočih v raziskavi GEM, ocenjuje zgodnji vladni odziv na pandemijo covida-19 kot nezadovoljiv ali nezadosten. V svetovnem merilu so vladni ukrepi najviše ocenjeni v Saudovi Arabiji, tesno pa ji sledijo Združeni arabski emirati in Nizozemska. Nizozemska je država, kjer podjetniška aktivnost tradicionalno uživa veliko podporo.

Slika 8.10: Ocene elementov vladnih ukrepov zaradi pandemije covida-19 v Sloveniji in evropskih državah (tehtano povprečje, 0 = zelo nezadovoljivo, 10 = zelo zadovoljivo)

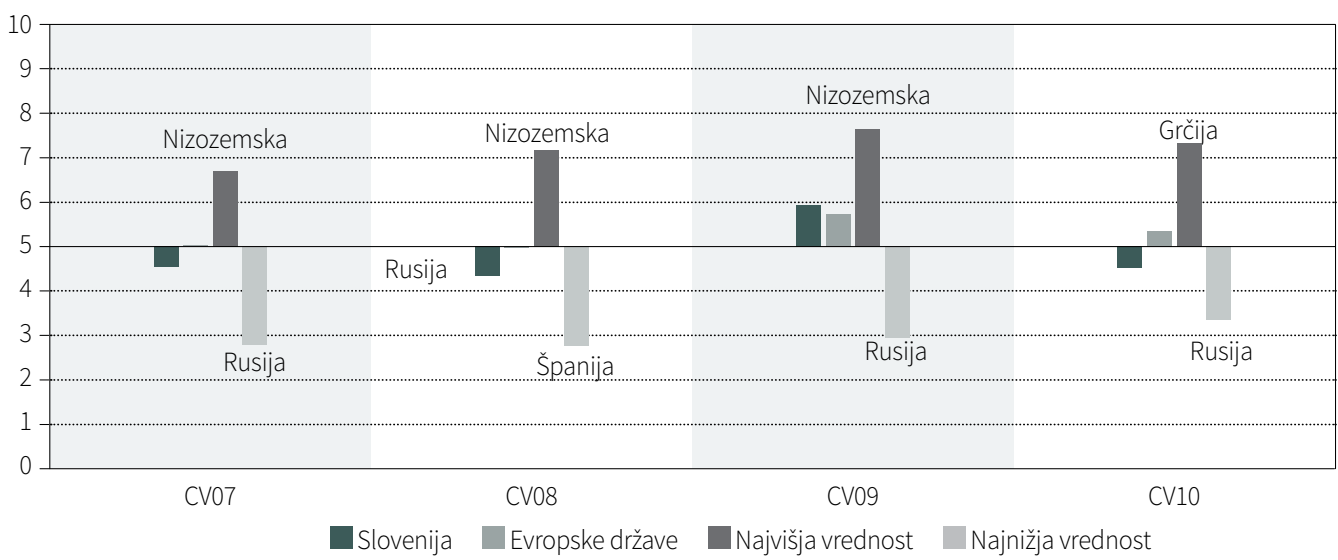

Legenda

VSloveniji...

CV07 je vlada sprejela učinkovite ukrepe za nova in rastoča podjetja, da se prilagodijo gospodarski realnosti, ki jo je povzročila pandemija covida-19.

CV08 je vlada sprejela učinkovite ukrepe, da bi preprečila zmanjšanje večjega števila novih in rastočih podjetij zaradi pandemije covida-19.

CV09 je vlada ukrepala, da bi med pandemijo covida-19 zaščitila delavce novih in rastočih podjetij in njihove stranke.

CV10 je zaradi pandemije covida-19 vlada znatno povečala digitalno ali spletno uveljavljanje predpisov za nova in rastoča podjetja.

GEM Slovenija 2020, NES

Slovenski izvedenci so se najbolj strinjali, da je vlada med pandemijo covida-19 zaščitila delavce novih in rastočih podjetij in njihove stranke (povprečna ocena 5,94 na lestvici od 0 do 10). Vse preostale trditve so negativno rangirane, s povprečnimi ocenami nižjimi od 5. Najmanj se slovenski izvedenci strinjajo s trditvijo, da je vlada sprejela učinkovite ukrepe, da bi preprečila zmanjševanje števila novih in rastočih podjetij zaradi pandemije covida-19, za evropskim povprečjem pa najbolj zaostajamo pri povečanju digitalnega ali spletnega uveljavljanja predpisov za nova in rastoča podjetja. Konec leta 2020 je Strateški svet za debirokratizacijo vladi predlagal nabor ukrepov na davčnem, gospodarskem in okoljskem področju, skaterimi se načrtuje poenostavitev poslovanja in v nekaterih primerih tudi znižanje davkov (GOV, 2020). Digitalizacija ostaja ključni steber okrevanja EU po pandemiji in je bistvenega pomena za spodbujanje novih oblik rasti in krepitev odpornosti EU. Evropska komisija je zato marca 2021 predstavila vizijo, cilje in možnosti za uspešno digitalno preobrazbo Evrope do leta 2030. Komisija predlaga digitalni kompas, s katerim bi se digitalne ambicije EU do leta 2030 prelile v konkretne ukrepe. Temelji na štirih glavnih točkah: 1) digitalno usposobljeno prebivalstvo in visoko kvalificirani strokovnjaki na digitalnem področju, 2) varne, učinkovite in trajnostne digitalne infrastrukture, 3) digitalna preobrazba podjetij in 4) digitalizacija javnih storitev (Evropska komisija, 2021). Učinki teh ukrepov bodo lahko predstavljeni v prihodnjih ciklih raziskave GEM. 
Rezultati linearne regresije med odzivom podjetniškega in vladnega sektorja sicer potrjujejo, da proaktivni odziv vlad na gospodarske posledice zaradi pandemije covida-19 pozitivno vpliva na preživetje in napredovanje novih in rastočih podjetij. Ukrepi, ki preprečujejo zaprtje in izgubo zaposlitve in omogočajo kontinuiteto vustvarjanju blaginje, prispevajo k prizadevanjem podjetnikov in jih dopolnjujejo (GEM NES-NECI, 2021). Kot smo omenili, je bila ocena odziva podjetniškega sektorja po mnenju izvedencev v vseh sodelujočih državah GEM pozitivna, kar kaže na to, da se podjetniki po svoji naravi vedno skušajo spoprijeti z neželenimi dogodki. Vendar pa lahko v razmerah, kot so trenutno, pomanjkanje ustreznih podpornih ukrepov za podjetja v nekaj mesecih privede do zaprtja številnih dejavnosti in s tem posledično do izgube številnih delovnih mest. Zaznati je mogoče, da se v nekaterih državah GEM takšne razmere že pojavljajo. V Sloveniji lahko po mnenju izvedencev nižjo povprečno oceno vladnega odziva v prvih mesecih epidemije pripišemo tudi nizki povprečni oceni vladnih politik. Podrobnejša raziskava na vzorcu vseh sodelujočih držav je namreč pokazala, da obstaja pozitivna povezava med vladnimi politikami in vladnim odzivom na posledice pandemije. Na tej osnovi je mogoče sklepati, da močnejša ko je vladna podpora za podjetništvo, bolj proaktiven je odziv vlade na trenutne krizne razmere zaradi pandemije covida-19.

Na tem mestu velja izpostaviti, da smo v okviru anketiranja GEM APS o vladnem odzivu na ekonomske posledice zaradi covida-19 povprašali tudi podjetnike. Ti so na vprašalnik odgovarjali po tako imenovanem prvem valu, ki je obetalo izboljšanje epidemiološke situacije in so vladni ukrepi zaradi pandemije že prišli bolj do izraza. Več kot polovica ustaljenih podjetnikov $(52,88 \%)$ meni, da se je slovenska vlada učinkovito odzvala na ekonomske posledice pandemije, kar je nekoliko nad evropskim povprečjem. Ta odstotek je še višji med zgodnjimi podjetniki (skoraj 57 \%), kar nas uvršča tik pod vrh, in sicer na drugo mesto v Evropi, za Luksemburgom. Res pa je, da lahko zaradi različnega obdobja anketiranja rezultati rangiranja držav odražajo tudi različno stanje podjetniškega ekosistema glede na epidemiološko stanje države.

Posebno poročilo raziskave GEM, v katerem je zbran pregled odzivov nacionalnih vlad na pandemijo covida-19, ugotavlja, da so se številne vlade osredotočile na ohranjanje delovnih mest, zagotavljanje finančne likvidnosti in spodbujanje prilaganja poslovnih modelov. Na osnovi izvedenih analiz se je izoblikovalo več širokih tem, o katerih bi morali razmisliti snovalci političnih ukrepov. Ti morajo ustvariti kohezivne, celostne in ugodne okvirne pogoje, da bodo podjetniki v svetu lahko uspevali tudi po covidu-19. Gre za načela, kot so (Ionescu-Somers in Tarnawa, 2020):

- jasno in jedrnato sporočanje političnih ukrepov tako, da koristijo čim večjemu številu podjetnikov;

- zanesljivost in odgovornost javne politike, ki spodbuja ustanavljanje novih in rast obstoječih podjetij; zahteva se zanesljivost pri oblikovanju političnih ukrepov s sprejetjem celostnega in večdimenzionalnega pristopa (kot je diagnostično orodje GEM-ovi podjetniški okvirni pogoji), odgovornost pa vključuje dolgoročno razmišljanje o politikah (ki ni omejeno z volilnimi roki) in izvajanje ukrepov na podlagi temeljitih analiz in podatkov, povezanih s potrebami podjetnikov ter identificiranimi vrzelmi v podjetniškem ekosistemu; to je izjemnega pomena, saj imajo lahko politične odločitve - tudi če prinašajo gospodarske koristi - včasih nenamerne in neželene škodljive socialne in okoljske učinke;

- inovativnost pri oblikovanju in razvoju politik z uvajanjem novih procesov, orodij in praks, ki omogočajo boljše reševanje sedanjih in prihodnjih zapletenih vprašanj, s katerimi se sooča družba, posledično pa pomagajo podjetnikom pri izkoriščanju in izrabi poslovnih priložnosti;

- poenostavitev politik tako, da bodo razumljive in lahko uporabne zlasti za nove udeležence neformalnega sektorja;

- priprava na prihodnje spremembe, na potencialni novi val pandemije. 


\subsection{Priporočila slovenskih izvedencev za izboljšanje podjetniškega okolja}

Vsako leto nacionalni izvedenci iz vsake sodelujoče države v okviru anketiranja NES podajo tri področja, ki podjetništvo po njihovem mnenju najbolj zavirajo v nacionalnem gospodarstvu, tri prednosti, ki po njihovem mnenju največ prispevajo k podjetniški aktivnosti, ter tri priporočila, kako bi podjetniško aktivnost lahko izboljšali. Na sliki 8.11 prikazujemo porazdelitev tem na osnovi multiplih spremenljivk. Na osnovi visokih in nizkih odstotkov je mogoče določiti, katere teme so izvedenci najpogosteje oziroma najredkeje navajali.

Slika 8.11: Zaviralni in spodbujevalni dejavniki podjetništva v Sloveniji

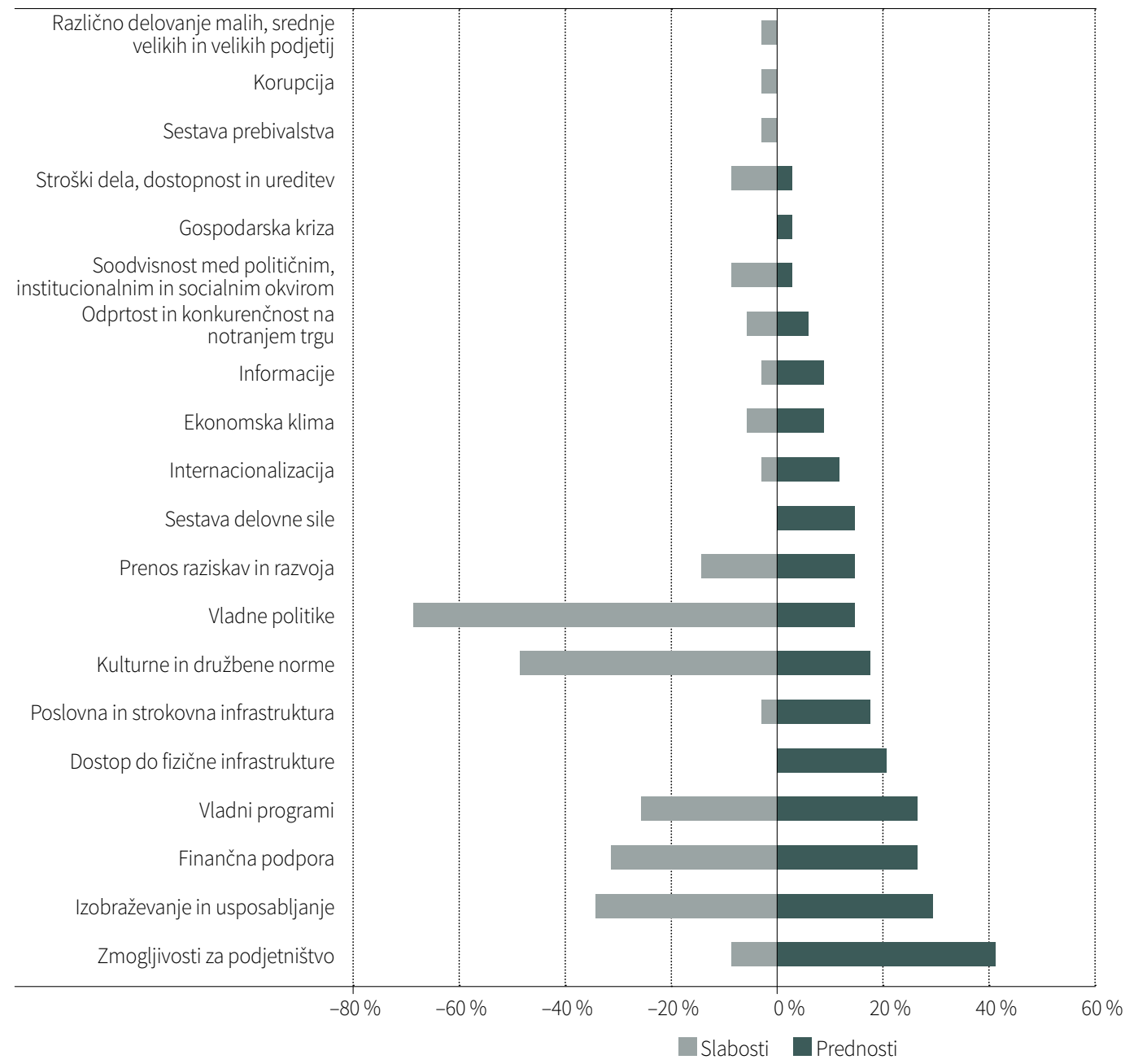


Največ zaviralnih dejavnikov za podjetništvo so slovenski izvedenci podali na področju vladnih politik (68,6 \% navedb), temu sledijo zaviralni dejavniki na področju kulturnih in družbenih norm (48,6 \% navedb). Skupna povprečna ocena kulturnih in družbenih norm se nam je ob soočanju s prvimi posledicami krize zaradi covida-19 sicer nekoliko izboljšala, kar je zagotovo spodbuden rezultat. Podrobnejši izračuni na vzorcu vseh držav, sodelujočih v GEM, namreč kažejo, da je prav povprečno stanje kulturnih in družbenih norm videti kot najpomembnejši pogoj učinkovitega odziva podjetniškega sektorja na trenutne krizne razmere kot posledice pandemije.

Tabela 8.1: Priporočila izvedencev za izboljšanje podjetništva v Sloveniji po izbranih okvirnih pogojih, GEM Slovenija 2020, NES

\section{Kategorije Priporočila}

- Uvedba podjetniških vsebin v celotno vertikalo šolskega sistema:

- spodbujanje podjetnosti, kreativnosti in inovativnosti med mladimi

- spodbujanje drznosti in proaktivnosti

- reševanje podjetniških izzivov

- projektno/ciljno izobraževanje

Izobraževanje

in

usposabljanje

\section{Vladne politike}

Finančna

podpora

programi
- Moduli finančnega opismenjevanja

- Praktične vsebine, vključevanje študentov v delo podjetij in spodbujanje prenosa znanja

- Sodelovanje šol s subjekti inovativnega okolja

- Usposabljanje za vodenje rastočih podjetij

- Usposabljanje za družbeno odgovornost in trajnostni razvoj

- Zmanjšanje administrativnih ovir:

- manj birokracije pri pridobivanju dovoljenj

- odprava nepotrebnih omejitev

- pospešitev postopkov

- Stimulativna davčna politika:

- prilagoditve za nastajajoča in nova podjetja

- zmanjšanje davka na dobiček

- zmanjšanje davka in prispevkov pri plačah

- Prenova delovnopravne zakonodaje

- Stabilnost davčne zakonodaje in drugih predpisov

- Definiranje podjetniških prioritet po statističnih regijah

- Oblikovanje nacionalne strategije za družbeno odgovornost podjetij

- Lažji in hitrejši dostop do virov financiranja

- Prilagoditev finančnih ukrepov za podporo najranljivejšim skupinam

- Več domačih skladov tveganega kapitala

- Višje subvencije za startup podjetja

- Povečanje fleksibilnosti poslovnih bank

- Več nepovratnih evropskih sredstev za inovativne projekte

- Izboljšanje dostopnosti podpore

- Konsistentnost in celovitost podpore:

- medsebojna usklajenost podpornih ukrepov in subjektov podpornega okolja

- dolgoročnost

- stabilnost

- Specializacija ukrepov za manj razvite regije

- Ločen operativni program za vzhodno in zahodno kohezijsko regijo

- Večja vlaganja v novo podporno tehnologijo

- Prepoznavanje dobrih praks in vzornikov

- Medijska popularizacija podjetništva

- Spodbujanje podjetništva kot vrednote

- Dvig družbenega zavedanja o samoodgovornosti 
Zanimivo je, da izvedenci največ prednosti za spodbujanje podjetništva $\vee$ Sloveniji vidijo $\vee$ zmogljivostih za podjetništvo (42,2\% navedb), v podjetniškem izobraževanju in usposabljanju $(29,4 \%$ navedb), finančni podpori za podjetništvo $(26,5 \%$ navedb) in $\vee$ vladnih programih za podjetništvo (26,5\% navedb). Po mnenju izvedencev k podjetništvu najbolj prispevajo individualizem, samoiniciativnost, iznajdljivost, inovativnost in fleksibilnost posameznikov, visoka izobrazba oziroma dovolj pridobljenega znanja na različnih področjih ter izrazit podjetniški duh in svobodomiselnost mladih. K temu spodbudno prispevajo tudi majhnost in povezanost v lokalnem okolju ter relativno dobra podjetniška tradicija in družinska podjetniška kultura.

V okviru izobraževanja in usposabljanja slovenski izvedenci pozdravljajo predvsem dostop do tehničnega in strokovnega znanja, postopno uvajanje podjetniških vsebin $v$ šole, kvaliteten izobraževalni sistem ter bogato ponudbo številnih neformalnih, zelo uporabnih izobraževanj in usposabljanj za podjetnike in podjetnice, na primer preko SPIRIT, SPOT točk. Med finančnimi mehanizmi so izpostavili podjetniške spodbude $v$ obliki subvencij, vavčerje, sofinanciranje tehnoloških in netehnoloških naložb podjetij vseh velikosti in dejavnosti ter relativno ugodno kreditiranje in aktivnosti eko sklada.

Kot prikazujemo v tabeli 8.1, so izvedenci v letu 2020 daleč največ priporočil podali na področju izobraževanja in usposabljanja za podjetništvo (65,7\% navedb), sledijo priporočila na področju vladnih politik (51,4\% navedb) in finančne podpore za podjetništvo (42,9\% navedb), temu pa sledijo priporočila na področju vladnih programov (25,7\% navedb) ter kulturnih in družbenih norm (20\%). 


\section{Literatura in viri}

1. Achim, M. V., Borlea, S. N., Vaidean, V. L. (2021). Culture, entrepreneurship and economic development: An empirical approach. Entrepreneurship Research Journal, 11(1).

2. Acs, Z. J., Estrin, S., Mickiewicz, T., Szerb, L. (2018). Entrepreneurship, institutional economics, and economic growth: an ecosystem perspective. Small Business Economics, 51(2), 501-514.

3. Acs, Z. J., Stam, E., Audretsch, D. B., O'Connor, A. (2017). The lineages of the entrepreneurial ecosystem approach, Small Business Economics, 49(1), 1-10.

4. Alam, M. Z., Nasir, N., Rehman, C. A. (2020). Intrapreneurship concepts for engineers: asystematic review of the literature on its theoretical foundations and agenda for future research. Journal of Innovation and Entrepreneursh, 9(8), 1-21.

5. Aldrich, H., Zimmer, C. (1986). The art and science of entrepreneurship. Ballinger, Cambridge, MA, 3-23.

6. AmCham, Karney (2020). AmCham Karney COVID-19 flash survey. https://www.amcham.si/upload/ custom/Kearney\%20\%20AmCham\%20-Covid19\%20Flash\%20Survey\%20_vS.pdf

7. Astrachan, J. H., Shanker, M. C. (2003). Family businesses' contribution to the U.S. economy: A closer look. Family Business Review, 16(3), 211-219.

8. Audretsch, D. B., Link, A. N. (2012). Entrepreneurship and innovation: public policy frameworks. Journal of Technology Transfer, 37(1), 1-17.

9. Aulet, B., Murray, F. (2013). A Tale of two Entrepreneurs: Understanding Differences in the Types of Entrepreneurship in the Economy. Ewing Marion Kauffman Foundation. http://real.mit.edu/documents/ AuletMurray_KauffmanPaper_a-tale-of-two-entrepreneurs.pdf

10. Autio, E., Acs, Z. J. (2010). Intellectual property protection and the formation of entrepreneurial growth aspirations. Strategic Entrepreneurship Journal, 4(4), 234-251.

11. Bager, T., Schott, T. (2004). Growth expectations by entrepreneurs in nascent firms, baby businesses and mature firms: Analysis of the Global Entrepreneurship Monitor surveys in Denmark 2000-2003. Paper to First GEM Research Conference: Entrepreneurship, Government Policies and Economic Growth, Berlin. 
12. Bain. (2020). Digital operations: don't depart without a strategy. https://www.bain.com/insights/ digital-operations-dont-depart-without-a-strategy/

13. Baum, J. R., Locke, E. A., Smith, K. J. (2001). A Multidimensional Model of Venture Growth. Academy of Management Journal, 44(2), 292-303.

14. Baum, J. R., Locke, E. A., Kirkpatrick, S. A. (1998). A longitudinal study of the relation of vision and vision communication to venture growth in entrepreneurial firms. Journal of Applied Psychology, 83(1), 43-54.

15. Bonesmo Fredriksen, K. (2012). Income Inequality in the European Union, OECD Economics Department Working Paper No. 952. OECD Publishing.

16. Bosma, N., Hill, S., Somers, A.I., Kelley, D., Levie, J., Tarnawa, A. (2020). Global Entrepreneurship Monitor: 2019/2020 Global Report. Global Entrepreneurship Research Association, London Business School.

17. Bosma, N., Wennekers, S., Amoros, J. E. (2012). Global Entrepreneurship Monitor, 2011 Extended Report. Babson College; Universidad de Desarrollo, Universiti Tun Abdul Razak.

18. Bowen, H., De Clercq, D. (2008). Institutional context and the allocation of entrepreneurial effort. Journal of International Business Studies, 39(4), 747-767.

19. Bravo-Biosca, A., Criscuolo, C., Menon, C. (2013). What Drives the Dynamics of Business Growth? OECD Publishing.

20. Brnot, N., Čuk, J. (2020). 40 \% diplomantov iz 2019 je do konca oktobra 2020 že našlo zaposlitev. SURS. https:// www.stat.si/StatWeb/News/Index/9287

21. Cacciotti, G., Hayton, J. C., Mitchell, J. R., Allen, D. G. (2020). Entrepreneurial fear of failure: Scale development and validation. Journal of Business Venturing, 35(5).

22. Caliendo, M., Goethner, M., Weißenberger, M. (2020). Entrepreneurial persistence beyond survival: Measurement and determinants. Journal of Small Business Management, 58(3), 617-647.

23. Caputo, A., Pellegrini, M. M. (2020). Introduction to "The Entrepreneurial Behaviour: Unveiling the Cognitive and Emotional Aspect of Entrepreneurship. In: Caputo, A., Pellegrini, M.M. (Eds.) The Entrepreneurial Behaviour: Unveiling the cognitive and emotional aspect of entrepreneurship (Entrepreneurial Behaviour Series), Emerald Publishing Limited, 1-5.

24. Carlsson-Wall, M., Douglas, E., Wennberg, K. (2012). Death by success? Financial distress in high growth firms. Working Paper, Stockholm School of Economics.

25. Carree, M., Thurik, R. (2006). Entrepreneurship and Economic Growth. Edward Elgar.

26. Chakrabarty, S. (2020). Intrapreneurship in teams/groups: self-determination theory and compensation. Journal of Small Business and Enterprise Development, 28(1), 45-58.

27. Coetzer, A., Kock, H., Wallo, A. (2017). Distinctive characteristics of small businesses as sites for informal learning. Human Resource Development Review, 16(2), 111-134.

28. Cooper, A. C., Woo, C. Y., Dunkelberg, W. C. (1989). Entrepreneurs' perceived chances for success. Journal of Business Venturing, 3(2), 97-108.

29. Curth, A., Chatzichristou, S., Devaux, A., Allinson, R., Bozeat, N., Henry, N. (2015). Entrepreneurship Education: A road to success. A compilation of evidence on the impact of entrepreneurship education strategies and measures. European Commission.

30. Delmar, F., Wiklund, J. (2008). The effect of small business managers' growth motivation on firm growth: a longitudinal study. Entrepreneurship Theory and Practice, 32(3), 437-457.

31. Delmar, F., Holmquist, C. (2004). Women's Entrepreneurship: Issues and Policies, 2nd OECD Conference of Ministers Responsible for Small and Medium-Sized Enterprises (SMEs) Istanbul, Turkey, 3-5 June 2004. 
32. DeTienne, D. R., McKelvie, A., Chandler, G. N. (2015). Making sense of entrepreneurial exit strategies: A typology and test. Journal of Business Venturing, 30(2), 255-272.

33. Estrin, S., Korosteleva, J., Mickiewicz T. (2014). Entrepreneurial Growth Aspirations, Innovation Propensity and National Knowledge Intensity: Unveiling the Complexity of the Relationship, using GEM data. GRINCOH Working Paper Series, Paper No. 3.08.2.

34. Eurofound. (2017). Income inequalities and employment patterns in Europe before and after the Great Recession. Publications Office of the European Union.

35. Evans, D. S., Leighton, L. S. (1989). Some empirical aspects of entrepreneurship. American Economic Review, 79(3), 519-535.

36. Evropska komisija. (2020). Evropski semester 2020: ocena napredka pri strukturnih reformah, preprečevanju in odpravljanju makroekonomskih neravnotežij ter rezultati poglobljenih pregledov v skladu z Uredbo (EU) št. 1176/2011; Poročilo o državi - Slovenija 2020.

37. Evropska komisija. (2021). Evropsko digitalno desetletje: Komisija začrtala pot k digitalno opolnomočeni Evropi do leta 2030. Bruselj, marec 2021. https://ec.europa.eu/commission/presscorner/detail/sl/IP_21_983

38. Fuentelsaz, L., González, C., Maícas, J. P. (2020). High-growth aspiration entrepreneurship and exit: the contingent role of market-supporting institutions. Small Business Economics, 1-20.

39. GEM NES-NECI. (2021). GEM NECI Explanatory Notes. Global Entrepreneurship Research Association, GERA.

40. Gieure, C., Benavides-Espinosa, M. D. M., Roig-Dobón, S. (2020). The entrepreneurial process: The link between intentions and behavior. Journal of Business Research, 112, 541-548.

41. GOV. (2020). Predlog ukrepov za debirokratizacijo na davčnem, gospodarskem in okoljskem področju. Vlada RS. https://www.gov.si/novice/2020-09-16-predlog-ukrepov-za-debirokratizacijo-na-davcnemgospodarskem-in-okoljskem-podrocju/

42. GOV. (2021). Odpravljanje posledic epidemije. Vlada RS. https://www.gov.si/teme/koronavirus-sars-cov-2/ odpravljanje-posledic-epidemije/

43. Herero, I. (2017). Family involvement and sustainable family business: Analyzing their effects on diversification strategies. Sustainability, 9(11), 2099.

44. Hessels, J., Van Galderen M., Thurik A. R. (2008). Entrepreneurial aspirations, motivations and their drivers. Small Business Economics, 31(3), 323-339.

45. Hiebl, M. R. W. (2014). Risk aversion in the family business: The dark side of caution. Journal of Business Strategy, 35(5), 38-42.

46. WEF. (2020). Global Competitiveness Report Special Edition 2020: How Countries are Performing on the Road to Recovery. https://www.weforum.org/reports/the-global-competitiveness-report-2020

47. Huđek, I., Tominc, P., Širec, K. (2021). The impact of social and cultural norms, government programs and digitalization as entrepreneurial environment factors on job and career satisfaction of freelancers. Sustainability, 13(2), 1-21.

48. Ionescu-Somers, A., Tarnawa, A. (2020). Diagnosing COVID-19 Impacts on Entrepreneurship: Exploring policy remedies for recovery. Global Entrepreneurship Research Association, London Business School.

49. Isenberg, D. J. (2010). How to start a entrepreneurial revolution. Harvard Busines Review, 88(6), 41-50.

50. Isenberg, D. J. (2011). The Entrepreneurship Ecosystem Strategy as a New Paradigm for Economy Policy: Principles for Cultivating Entrepreneurship. Babson Entrepreneurship Ecosystem Project. Babson Park, Babson College. 
51. Kajzer, A. (2020). Vpliv epidemije na trg dela. UMAR, december 2020. https://www.umar.gov.si/fileadmin/ user_upload/publikacije/kratke_analize/2020_12_Vpliv_epidemije_na_trg_dela/Vpliv_epidemije_na_ trg_dela_v_EU_Kajzer_01.pdf

52. Kelley, D., Brush, C. G., Corbett, A. C. Majbouri, M. (2020). Global Entrepreneurship Monitor 2019/2020 United States Report. Babson College.

53. Kelley, D., Gartner, W. B., Allen, M. (2020). GEM - Global Entrepreneurship Monitor Family Business Report. Babson Park: Babson College Press, Babson Park, MA.

54. Klyver, K., Nielsen, S., Evald, M. (2013). Women's self-employment: An act of institutional (dis)integration? A multilevel, cross-country study. Journal of Business Venturing, 28(4), 474-488.

55. KMU Forschung Austria. (2008). Overview of Family Business Relevant Issues, Contract No. 30-CE 0164021/0051 Final Report. Vienna. http://www.europeanfamilybusinesses.eu/uploads/Modules/Publications/ overview-of-family-business-relevant-issues.pdf

56. Koellinger, P. (2008). Why are some entrepreneurs more innovative than others? Small Business Economics, 31(1), 1-37.

57. Kolvereid, L., Bullvag, E. (1996). Growth intentions and actual growth: The impact of entrepreneurial choice. Journal of Enterprising Culture, 4(1), 1-17.

58. Kraiczy, N. D., Hack, A., Kellermanns, F. W. (2015). What makes a family firm innovative? CEO risk-taking propensity and the organizational context of family firms. Journal of Product Innovation Management, 32(3), 334-348.

59. Lafuente, E., Acs, Z. J., Sanders, M., Szerb, L. (2020). The global technology frontier: productivity growth and the relevance of Kirznerian and Schumpeterian entrepreneurship. Small Business Economics, 55, 153-178.

60. Lee, M. O., Vouchilas, G. (2016). Preparing to age in place: attitudes, approaches, and actions. Housing and Society, 43(6), 69-81.

61. Lévesque, M., Minniti, M. (2006). The effect of aging on entrepreneurial behavior. Journal of Business Venturing, 21, 177-194.

62. Levie, J., Lerner, M. (2009). Resource mobilization and performance in family and nonfamily businesses in the United Kingdom. Family Business Review, 22(1), 25-38.

63. Levie, J. D., Autio, E. (2008). A theoretical grounding and test of the GEM model. Small Business Economics, 31(3), 235-263.

64. Ljubotina, P., Vadnjal, J. (2017). Succeeding a family business in a transition economy: is this the best that can happen to me? Kybernetes, 46(8), 1366-1385.

65. Llewellyn, D. W. T., Autio, E. (2019). Innovation Ecosystems. SSRN Electronic Journal. https://ssrn.com/ abstract $=3476925$

66. Lombardi, R., Tiscini, R., Trequattrini, R., Martiniello, L. (2020). Strategic entrepreneurship: Personal values and characteristics influencing SMEs' decision-making and outcomes. The Gemar Balloons case. Management Decision, ahead-of-print.

67. Mason, C., Brown, R. (2014). Entrepreneurial ecosystems and growth-oriented entrepreneurship. Background paper prepared for the workshop organised by the OECD LEED Programme and the Dutch Ministry of Economic Affairs on Entrepreneurial Ecosystems and Growth Oriented Entrepreneurship, The Hague, Netherlands.

68. McMullen, J. S., Dimov, D. (2013). Time and the entrepreneurial journey: the problems and promise of studying entrepreneurship as a process. Journal of Management Studies, 50(8), 1481-1512. 
69. Morales-Alonso, G., Núñez Guerrero, Y., Aguilera, J. F., Rodríguez-Monroy, C. (2020). Entrepreneurial aspirations: economic development, inequalities and cultural values. European Journal of Innovation Management. Ahead-of-print.

70. Munoz-Bullon, F., Sanchez-Bueno, M. J., Vos-Saz, A. (2015). Nascent entrepreneurs' personality attributes and the international dimension of new ventures. International Entrepreneurship and Management Journal, 11(3), 473-492.

71. Nguyen, X. T. (2020). Factors affecting entrepreneurial decision of nascent entrepreneurs belonging generation $Y$ in Vietnam. Journal of Asian Finance, Economics and Business, 7(8), 407-417.

72. Nielsen, S., Klyver, K., Evald, M. (2010). Denmark. In: Fielden, S., Davidson, M. (ed.), International Research Handbook on Successful Women Entrepreneurs. Edward Elgar, Cheltenham.

73. OECD. (2017a). Enhancing the Contributions of SMEs in a Global and Digitalised Economy. https://www.oecd. org/mcm/documents/C-MIN-2017-8-EN.pdf

74. OECD. (2017b). Key Issues for Digital Transformation in the G20. Report prepared for a joint G20 German Presidency / OECD conference.

75. OECD. (2020). Start-ups in the time of COVID-19: Facing the challenges, seizing the opportunities. http:// www.oecd.org/coronavirus/policy-responses/start-ups-in-the-time-of-covid-19-facing-the-challengesseizing-the-opportunities-87219267/

76. OECD/European Union. (2019). The Missing Entrepreneurs 2019: Policies for Inclusive Entrepreneurship. OECD Publishing. https://doi.org/10.1787/3ed84801-en

77. OECD/European Union. (2020). Inclusive Entrepreneurship Policies, Country Assessment Notes: Slovenia 2020. OECD Publishing. https://www.oecd.org/cfe/smes/Slovenia-IE-2020.pdf

78. Parker, S. C. (2009). The economics of entrepreneurship. Cambridge University Press.

79. Pinkovetskaia, I. S., Schennikova, N. V., Kryukova, L. I. (2020). Exit of Entrepreneurs from Business: Reasons and Strategies. Journal of History Culture and Art Research, 9(1), 365-374.

80. Puente, R., Cervilla, M. A., González, C. G., Auletta, N. (2017). Determinants of the growth aspiration: a quantitative study of Venezuelan entrepreneurs. Small Business Economics, 48, 699-726.

81. PwC. (2018). Will robots really steal our jobs? An international analysis of the potential long-term impact of automation. Price WaterHouse Coopers.

82. Amit, R., Meuller, E., Cockburn, I. (1995). Opportunity costs and entrepreneurial activity. Journal of Business Venturing, 10(2), 95-106.

83. Rae, D., Penaluna, A., Dhaliwal, H. (2011). Higher education and graduate enterprise in thenew era should every student learn enterprise skills? Graduate Market Trends, Higher Education Careers Service Unit, Manchester, 9-11.

84. Ramawati, Y., Sudiro, A., Rohman, F., Mugiono. (2020). Technique of understanding enterpreunal intention: A conceptual study. Journal of Advanced Research in Dynamical and Control Systems, 12(3) Special Issue, 529-537.

85. Raza, A., Muffatto, M., Saeed, S. (2018). Cross-country differences in innovative entrepreneurial activity: An entrepreneurial cognitive view. Management Decision, 58(7), 1301-1329.

86. Rebernik, M., Tominc, P., Širec, K., Bradač Hojnik, B., Rus, M., Crnogaj, K. (2019). Neizkoriščen podjetniški potencial: GEM Slovenija 2018, Univerzitetna založba UM.

87. Renko, M. (2013). Early challenges of nascent social entrepreneurs. Entrepreneurship Theory and Practice, 37(5), 1045-1069. 
88. Reynolds, P., Bosma, N., Autio, E., Hunt, S., De Bono, N., Servais, I., Lopez-Garcia, P., Chin, N. (2005). Global Entrepreneurship Monitor: Data Collection Design and Implementation 1998-2003, Small Business Economics, 24(3), 205-231.

89. Rihter, L., Leskošek V. (2020). Družbeni vidiki naraščanja nestandardnih oblik dela: dohodkovna neenakost, revščina in vertikalna mobilnost. V: Kresal Šoltes, K., Strban, G., Domadenik, P. (ur.), Prekarno delo. Multidisciplinarna analiza, 213-231. Pravna fakulteta in Ekonomska fakulteta, UL.

90. Roland Berger. (2020). Reboot: Preparing for the new normal in technology-based industries. Roland Berger. https://www.rolandberger.com/en/

91. Santos, E., Fernandes, C. I., Ferreira, J. J. (2021). The driving motives behind informal entrepreneurship: The effects of economic-financial crisis, recession and inequality. The International Journal of Entrepreneurship and Innovation, 22(1), 5-17.

92. Saridakis, G., Marlow, S., Storey, D. (2014). Do different factors explain male and female self-employment rates? Journal of Business Venturing, 29(3), 345-362.

93. Schoar, A. (2010). The divide between subsistence and transformational entrepreneurship. Innovation Policy and the Economy, 10(1), 57-81.

94. Schott, T., Sedaghat, M. (2014). Innovation embedded in entrepreneurs' networks and national education system. Small Business Economics, 43(2), 463-476.

95. Schwab, K., Zahidi, S. (2020). The Global Competitiveness Report 2020. World Economic Forum.

96. Sharma, P. (2004). An overview of the field of family business studies: Current status and directions for the future. Family Business Review, 17(1), 1-36.

97. Spigel, B. (2017). The relational organization of entrepreneurial ecosystems. Entrepreneurship Theory and Practice, 41(1), 49-72.

98. SPIRIT. (2020). Program dela in finančni načrti za leti 2020 in 2021. SPIRIT Slovenija, junij 2020. https:// www.spiritslovenia.si/resources-new/vsebine/SPIRIT/StaticneStrani/7/Spremembe\%20Programa\%20 dela\%20in\%20finan\%C4\%8Dnega\%20na\%C4\%8Drta\%20za\%20leti\%202020\%20in\%202021\%20-\%20 $\%$ C4\%8Distopis.pdf

99. SPS. Slovenski podjetniški sklad. (2021). Produkti sklada. https://podjetniskisklad.si/sl/produkti-sklada/ program-mladi/zagonske-spodbude

100. Stam, E. (2015). Entrepreneurial ecosystems and regional policy: a sympathetic critique. European Planning Studies, 23(9), 1759-1769.

101. Stam, E., Spigel, B. (2018). Entrepreneurial ecosystems. In: R. Blackburn, D. De Clercq, J. Heinonen, Z. Wang (Ed.), Sage handbook for entrepreneurship and small business. Sage Publications Ltd.

102. Stam, E., van de Ven, A. (2019). Entrepreneurial ecosystem elements. Small Business Economics, 56, 809-832.

103. Tavčar, B. (2021). Kriza in insolventnost poslovnih subjektov v Sloveniji. UMAR.

104. Thiele, P., Fellnhofer, K. (2015). The impact of pre-startup planning on the strength of planning assumptions and the mode of processing. International Journal of Entrepreneurial Venturing, 7(2), 173-193.

105. Tominc, P., Rebernik, M., Bradač Hojnik, B., Širec, K. (2019). Danube region entrepreneurship observatory: entrepreneurship ecosystem, women and youth entrepreneurship. Pearson.

106. Tominc, P., Širec, K. (2020). An innovation gap between family and nonfamily businesses: a case study of post-transition economies. European Journal of International Management, 1-19.

107. UMAR. Urad RS za makroekonomske analize in razvoj. (2019). Poročilo o razvoju. UMAR. 
108. UMAR. Urad RS za makroekonomske analize in razvoj. (2020a). Jesenska napoved gospodarskih gibanj 2020. UMAR. https://www.umar.gov.si/fileadmin/user_upload/napovedi/jesen/2020/JNGG_2020.pdf

109. UMAR. Urad RS za makroekonomske analize in razvoj. (2020b). Poročila o produktivnosti 2020. UMAR. https://www.umar.gov.si/fileadmin/user_upload/publikacije/Porocilo_o_produktivnosti/2020/ slovenski/POP2020_01.pdf

110. UMAR. Urad RS za makroekonomske analize in razvoj. (2020c). Poročilo o razvoju 2020. UMAR. https://www. umar.gov.si/fileadmin/user_upload/razvoj_slovenije/2020/slovenski/POR2020_celota_za_splet.pdf

111. UMAR. Urad RS za makroekonomske analize in razvoj. (2020d). Scenarij COVID-19. UMAR. https://www. umar.gov.si/fileadmin/user_upload/napovedi/vmesna/marec_2020/PN2020_Covid19_p.pdf

112. UNDP. United Nations Development Programme. (2019). Human Development Report: Gender inequality index. http://hdr.undp.org/en/content/gender-inequality-index-gii

113. Urbano, D., Aparacio, S., Querol, V. (2016). Social Progress orientation and innovative entrepreneurship: an international analysis. Journal of Evolutionary Economics, 26(5), 1033-1066.

114. Van Praag, C. M., Van Ophem, H. (1995). Determinants of willingness and opportunity to start as an entrepreneur. KYKLOS, 48, 513-540.

115. Vlada RS. (2021). Odpravljanje posledic epidemije. https://www.gov.si/teme/koronavirus-sars-cov-2/ odpravljanje-posledic-epidemije/

116. Vodă, A. I., Haller, A., Anichiti, A., Butnaru, G. I. (2020). Testing entrepreneurial intention determinants in post-transition economies. Sustainability, 12(24), 1-28.

117. WEF. World Economic Forum. (2020). Global gender Gap Report 2020. http://reports.weforum.org/ global-gender-gapreport-2020/the-global-gender-gap-index-2020/results-and-analysis/

118. Wennekers, S., Van Stel, A., Carree, M., Thurik, A. R. (2010). The Relationship Between Entrepreneurship and Economic Development: Is it U-Shaped? Foundations and Trends in Entrepreneurship, 6(3), 167-237.

119. Westhead, P., Cowling, M. (1998). Family firm research: The need for a methodological rethink. Entrepreneurship Theory and Practice, 23(1), 31-56.

120. Wiklund, J., Shepherd, D. (2003). Aspiring for and achieving growth: the moderating role of resources and opportunities. Journal of Management Studies, 40, 1919-1941.

121. Young, S. L., Welter, C., Conger, M. (2018). Stability vs. flexibility: the effect of regulatory institutions on opportunity type. Journal of International Business Studies, 49(4), 407-441.

122. Zieba, K. (2017). High Growth Aspirations of Nascent Entrepreneurs: Why Do They Fall? Studia i Materiaty, 94-102.

123. ZRZS. Zavod RS za zaposlovanje. (2020a). Vpliv epidemije SARS-CoV-2 na trg dela v Sloveniji: marec in april 2020. https://www.ess.gov.si/_files/13330/Analiza_vpliva_epidemije_SARS-CoV-2_na_trg_dela.pdf

124. ZRZS. Zavod RS za zaposlovanje. (2020b). Trg dela v številkah. https://www.ess.gov.si/trg_dela/ trg_dela_v_stevilkah

125. ZRZS. Zavod RS za zaposlovanje. (2020c). Strokovna izhodišča za leto 2021. https://www.ess.gov.si/_ files/13699/Strokovna_izhodisca_leto_2021.pdf

126. ZRSZ. Zavod RS za zaposlovanje. (2020d). Strokovna izhodišča za leto 2021. Novembre 2020. https://www. ess.gov.si/files/13699/Strokovna_izhodisca_leto_2021.pdf

127. ZRSZ. Zavod RS za zaposlovanje. (2021). Stopnja registrirane brezposelnosti. https://www.ess.gov.si/ trg_dela/trg_dela_v_stevilkah/stopnja_registrirane_brezposelnosti 



\section{Značilnosti vzorca slovenskih izvedencev v letu 2020}

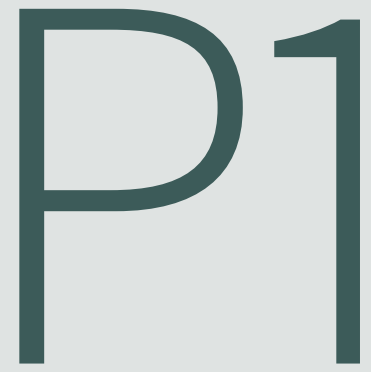

Spol

anketiranih
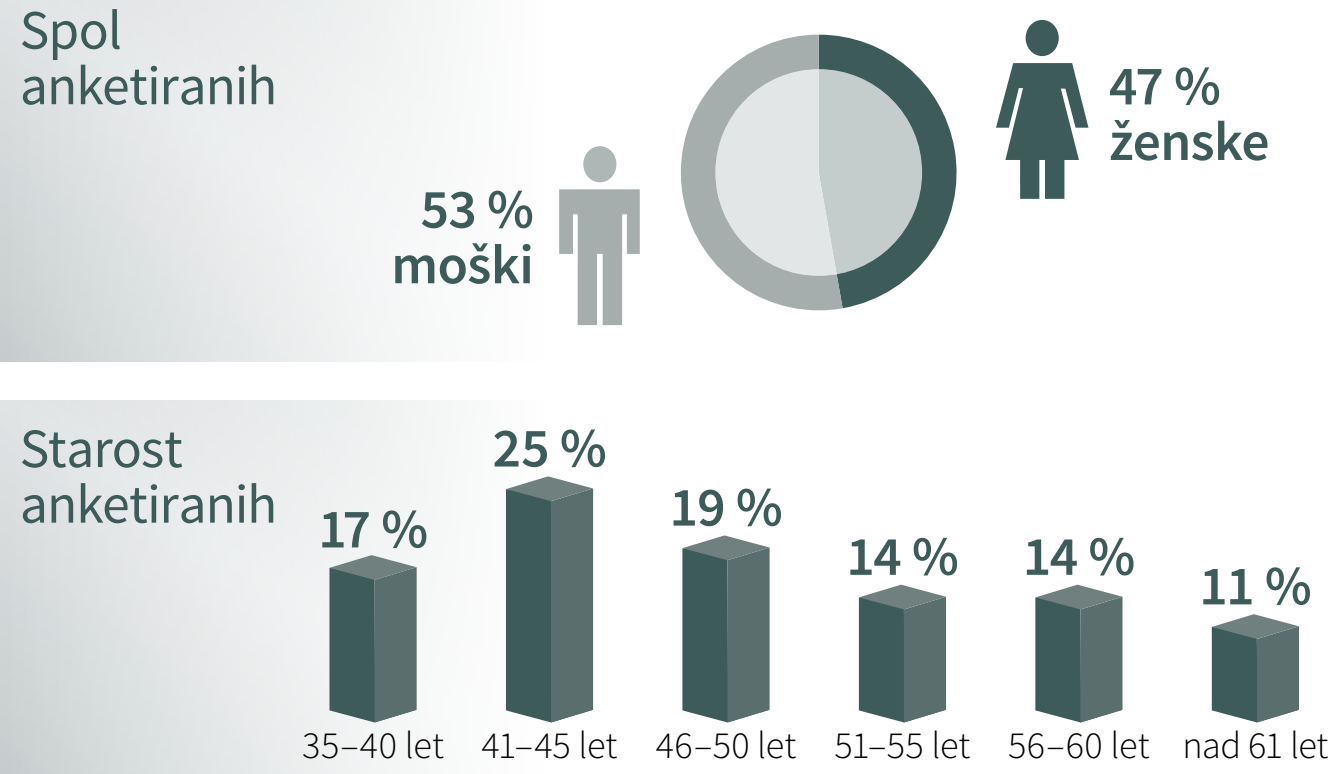

Izobrazba anketiranih
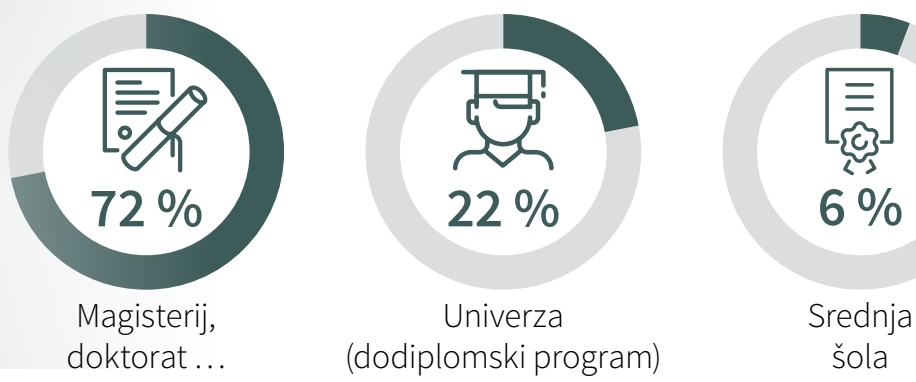
Kaj od navedenega izvedenca najbolje opisuje (možnih več odgovorov)

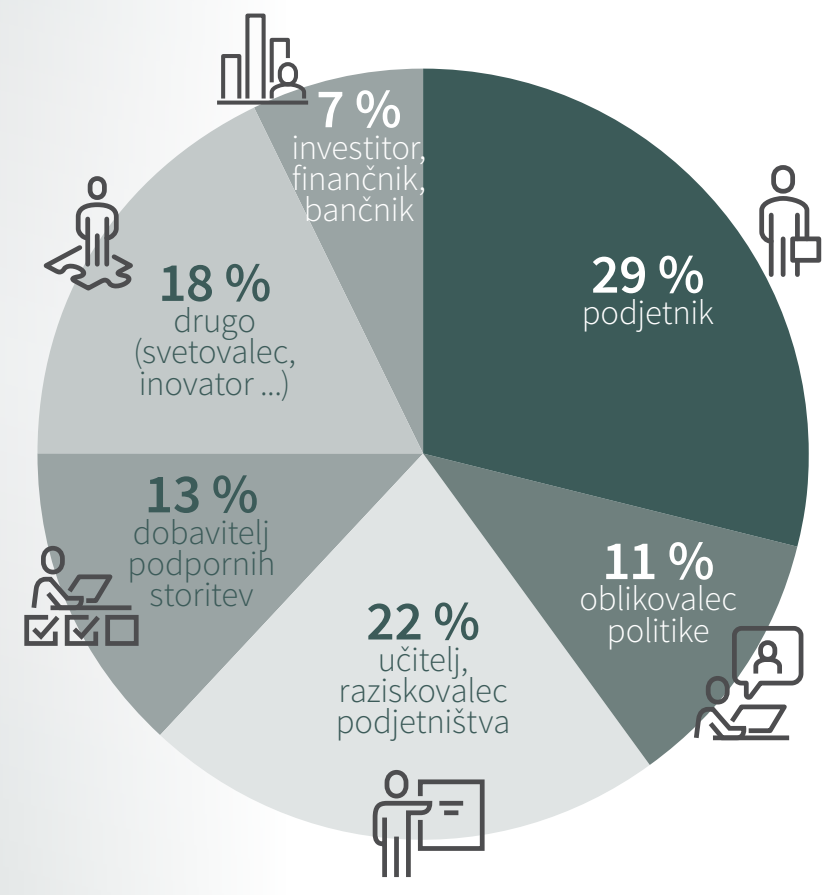

Izkušnje na področju podjetništva

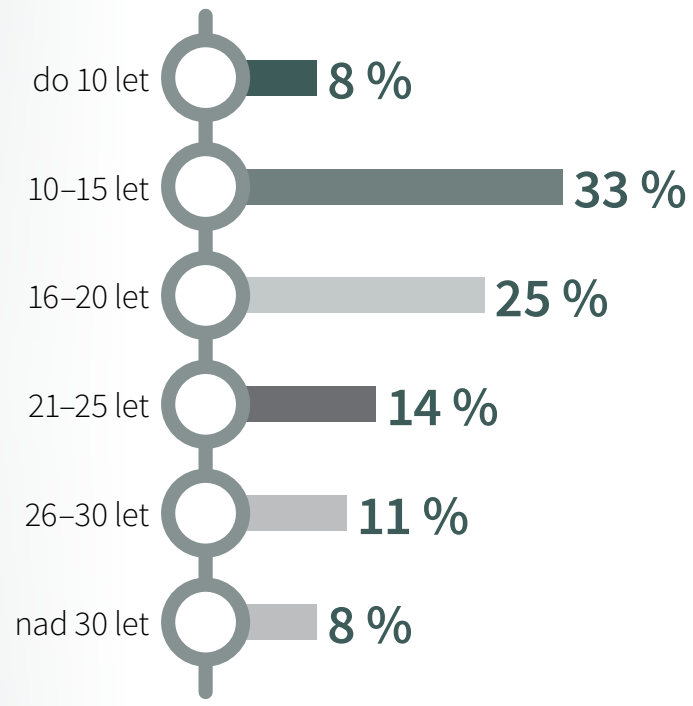

Izkušnje 


\section{Metodološka pojasnila}

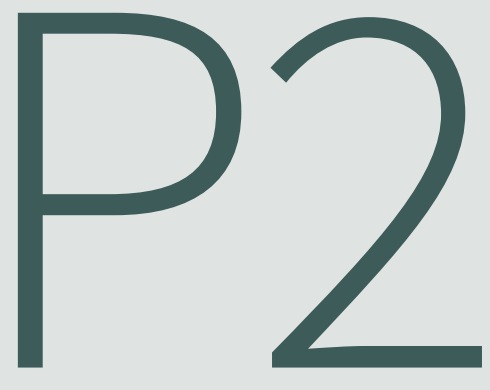

\section{Razlika med podatki GEM in podatki poslovnih registrov ali AJPES}

Kljub dolgoletnemu pojasnjevanju razlik med podjetništvom kot procesom, v katerem sodeluje posameznik, ter podjetništvom, ki se ukvarja z organizacijskimi in pravnimi subjekti (d.d., d.o.o., s.p.), še vedno pogosto prihaja do mešanja podjetniškega procesa in poslovnega registra, do mešanja ljudi in organizacij. Oba vidika je pomembno proučevati, vendar pa vsak zahteva svoje podatkovne vire. Kadar se ukvarjamo s podjetji kot organizacijskimi in poslovnimi subjekti, lahko uporabljamo podatkovne podlage, ki nam jih ponujajo poslovni registri, AJPES, Statistični urad RS, Eurostat ali druge specializirane organizacije in podjetja, ki se ukvarjajo s poslovnimi podatki (eBonitete, GVIN, ipd.). Ko pa imamo opraviti z ljudmi, lahko vpogled v njihove sposobnosti, namere, strahove, ambicije ipd. dobimo samo tako, da z zanesljivo metodologijo anketiramo statistično zanesljiv vzorec prebivalstva.

GEM je družbena raziskava, ki se ukvarja s posamezniki. Z vidika raziskovalne perspektive GEM so posamezniki tisti, ki so primarni akterji ustanovitve, zagona in vzdrževanja novega podjema. Zato seveda obstajajo nekatere bistvene razlike med podatki, ki jih zagotavlja GEM, in tistimi, ki jih lahko pridobimo v različnih poslovnih registrih in statističnih podatkovnih bazah. $V$ nadaljevanju navajamo nekaj pomembnejših razlik (Bosma et al., 2008):

- Podatki GEM so pridobljeni v raziskavi, ki je harmonizirana med vsemi sodelujočimi državami. Kljub iniciativam Eurostata, OECD in Svetovne banke harmonizacija podatkov nacionalnih poslovnih registrov še ni uresničena.

- Metodologija GEM vsebuje statistično negotovost agregatnih rezultatov (na ravni države), kar ponazarjamo z objavljanjem intervalov zanesljivosti za ugotovljene podjetniške indekse. Podatki iz poslovnega registra so »številčni podatki« statistične množice in kot taki ne 
zahtevajo intervala zanesljivosti. Vendar je število »umetnih« registracij za določene države neznano. Nekateri podjemi sploh niso registrirani (ali se jim ni treba registrirati), nekatera podjetja so registrirana samo zaradi davčnih razlogov, ne da bi v njih potekala kakršna koli podjetniška aktivnost. Obseg, $v$ kolikšni meri se to dogaja, verjetno močno variira med državami.

- GEM spremlja ljudi, ki so v procesu ustanavljanja podjetja (nastajajoči podjetniki), kakor tudi ljudi, ki so lastniki in managerji svojega podjetja (nova in ustaljena podjetja). GEM tudi ugotavlja nagnjenost $k$ podjetništvu in njegovo dojemanje. Vpogled $v$ najzgodnejše faze podjetništva in duh podjetnosti pa je seveda zelo relevantna informacija za oblikovalce ekonomske in razvojne politike.

- Bistvo GEM ni v preštevanju podjetij in izračunavanju stopnje ustanavljanja podjetij. Gre za merjenje podjetniškega duha in podjetniške aktivnosti v različnih fazah podjetniškega procesa. Zato podatki GEM niso najboljši vir za proučevanje podjetij (kot pravnih subjektov) in njihovih značilnosti. Za panožno razvrstitev obstoječih podjetij so na primer zagotovo boljši podatki, ki jih zagotavljajo poslovni registri.

- GEM ponuja številne podatke, ki jih ni mogoče dobiti iz poslovnih registrov. Takšni primeri so motivacija za samozaposlovanje, raven podjetniške aktivnosti, strah pred neuspehom ali pričakovanja bodoče rasti. Vendarle pa je pri tem treba biti pozoren na to, da se takšne značilnosti ugotavljajo na primernem (in dovolj velikem) slučajnem vzorcu. $V$ ta namen je ponekod smiselno združevati vzorce GEM iz več let.

V Sloveniji se raziskovalci podjetništva ukvarjamo tako s primarnimi podatki, ki jih dobimo na temelju anketiranega vzorca (prebivalcev, podjetnikov, managerjev v podjetjih ipd.), kakor tudi s sekundarnimi podatki, ki jih ponujajo statistični urad, poslovni register ali različne podatkovne zbirke AJPES. Z izjemo GEM se pri primarnih podatkih pogosto pokaže, da niso harmonizirani s podobnimi raziskavami v svetu, pri uporabi podatkov iz registra pa se pojavlja dodatni problem, da niso ažurirani ter da so v njem številni organizacijski subjekti, ki so sicer registrirani, a niso poslovno aktivni. V drugi longitudinalni slovenski raziskavi podjetništva, ki poteka od leta 1998, v Slovenskem podjetniškem observatoriju, je ta zadrega rešena tako, da so v analizah smiselno upoštevani samo tisti subjekti, ki oddajo poročila o poslovanju, torej živi gospodarski subjekti, ki na trgu tudi dejansko sodelujejo v ekonomskem življenju in vplivajo nanj.

\section{Ključne mere GEM}

Navajamo nekatere ključne mere, ki jih uporablja GEM, skupaj z njihovimi delovnimi definicijami. GEM-ovi okvirni pogoji za podjetništvo, ki jih uporablja NES, so opisani v 8. poglavju. Do opisa vseh mer lahko dostopate tudi neposredno na internetni strani Globalnega podjetniškega monitorja (www.gemconsortium.org) na naslednji način: Data $\rightarrow$ Knowledge Base $\rightarrow$ Methodology $\rightarrow$ Terminology $\rightarrow$ Definition ali jih poiščete na https://www.gemconsortium.org/about/wiki.

\section{Mera}

\section{Odnos do podjetništva in njegovo dojemanje (Entrepreneurial attitudes and perceptions)}

Poznavanje startup podjetnika (Knowing start-up entrepreneur)

Zaznane priložnosti (Perceived opportunities)
Odstotek populacije med 18. in 64. letom, ki osebno pozna nekoga, ki je v zadnjih dveh letih ustanovil podjetje.

Odstotek populacije med 18. in 64. letom, ki na območju, na katerem živi, vidi v prihodnjih 6 mesecih dobre priložnosti za ustanovitev podjetja. 
Enostavnost začetka poslovanja

(Ease of starting a business)

\section{Zaznane zmogljivosti}

(Perceived capabilities)

\section{Podjetniške namere}

(Entrepreneurial intention)

\section{Stopnja strahu pred neuspehom} (Fear of failure rate)

\section{Podjetništvo kot zaželena podjetniška izbira (Entrepreneurship as desirable career choice) \\ Visok status uspešnega podjetništva (High-status successful entrepreneurship)}

Pozornost medijev do podjetništva (Media attention for entrepreneurship)

\section{Oportunizem \\ (Opportunism) \\ Proaktivnost \\ (Proactivity)}

\section{Inovacijska zmogljivost \\ (Innovation capability)}

\section{Vizija}

(Vision)

Odstotek populacije med 18. in 64. letom, ki se strinja s trditvijo, da je v njihovi državi enostavno začeti s poslovanjem.

Odstotek populacije med 18. in 64. letom, ki meni, da imajo potrebne veščine in znanje, da bi ustanovili podjetje.

Odstotek populacije med 18. in 64. letom (posamezniki, ki so vključeni v katero koli podjetniško aktivnost, so izključeni), ki so potencialni podjetniki, saj nameravajo $v$ roku treh let ustanoviti podjetje.

Odstotek populacije med 18. in 64. letom (med tistimi, ki zaznavajo podjetniške priložnosti), ki navajajo, da bi jih strah pred neuspehom odvrnil od ustanovitve podjetja.

Odstotek populacije med 18. in 64. letom, ki se strinja s trditvijo, da je v njihovi državi podjetništvo zaželena poklicna izbira.

Odstotek populacije med 18. in 64. letom, ki se strinja s trditvijo, da so v njihovi državi uspešni podjetniki spoštovani in ugledni.

Odstotek populacije med 18. in 64. letom, ki se strinja s trditvijo, da je v njihovi državi v javnih medijih pogosto videti zgodbe o uspešnih novih podjetjih.

Odstotek populacije med 18. in 64. letom, ki se strinja s trditvijo, da redko vidijo poslovne priložnosti, četudi je to na področju, ki ga sicer dobro poznajo.

Odstotek populacije odraslih med 18 . in 64 . letom, ki se strinja s trditvijo, da bi se kljub zaznani dobičkonosni priložnosti nanjo redko odzvali.

Odstotek populacije med 18. in 64. letom, ki se strinja s trditvijo, da jih imajo drugi ljudje za zelo inovativne.

Odstotek populacije med 18. in 64. letom, ki se strinja s trditvijo, da je vsaka odločitev, ki jo sprejmejo, del njihovega dolgoročnega kariernega načrta.

\section{Motivacija}

Motiv za podjetništvo: ustvarjanje sprememb v svetu

(Motive for starting a business: To make a difference in the world)

\section{Motiv za podjetništvo: ustvarjanje premoženja oziroma visokega dohodka \\ (Motive for starting a business: To build great wealth or very high income)}

Motiv za podjetništvo: nadaljevanje družinskega podjetja oziroma tradicije (Motive for starting a business: To continue family tradition)

Motiv za podjetništvo: potreba po preživetju, ker so službe redke (Motive for Starting a Business: To earn a living beacuse jobs are scarce)
Odstotek zgodnjih podjetnikov (nastajajočih in novih), ki se strinjajo s trditvijo, da je bil njihov motiv za podjetništvo prispevati k ustvarjanju sprememb v svetu.

Odstotek zgodnjih podjetnikov (nastajajočih in novih), ki se strinjajo s trditvijo, da je bil njihov motiv za podjetništvo želja po ustvarjanju premoženja oziroma večjega dohodka.

Odstotek zgodnjih podjetnikov (nastajajočih in novih), ki se strinjajo s trditvijo, da je bil njihov motiv za podjetništvo želja po nadaljevanju družinskega podjetja oziroma tradicije.

Odstotek zgodnjih podjetnikov (nastajajočih in novih), ki se strinjajo s trditvijo, da je bil njihov motiv za podjetništvo potreba po preživetju, ker so službe redke. 
Podjetniška aktivnost (Entrepreneurial activity)

Stopnja nastajajočega podjetništva (Nascent entrepreneurship rate)

\section{Stopnja novega podjetništva}

(New business ownership rate)

\section{Celotna zgodnja podjetniška aktivnost}

(Total Early-stage Entrepreneurial Activity - TEA)

\section{Stopnja ustaljenega podjetništva (Established Business Ownership rate $-E B O)$}

Stopnja celotne podjetniške aktivnosti (Overall entrepreneurial activity rate)

\section{Izstop iz podjetništva, poslovanje podjetja se nadaljuje (Exit, business continues)

Izstop iz podjetništva, poslovanje
podjetja preneha
(Exit, business does not continue)

\section{Stopnja prenehanja poslovanja}

(Business discontinuation rate)

\section{Opustitveni indeks}

(Entrepreneurship exit rate)

Podjetniška aktivnost zaposlenih (Entrepreneurial Employee Activity - EEA)

\section{Socialna podjetniška aktivnost}

(Social Entrepreneurial Activity - SEA)

Družinska zgodnjepodjetniška aktivnost (Family early-stage entrepreneurial activity)

Vključenost $v$ gig ekonomijo (Gig economy participation)

\section{Vključenost v delitveno ekonomijo} (Sharing economy participation)
Odstotek populacije med 18. in 64. letom, ki so trenutno nastajajoči podjetniki, to pomeni, da so aktivno vključeni v ustanavljanje podjetja, ki bo v celoti ali delno v njihovi lasti; podjetje (vključno z lastniki) še ni izplačevalo plač, nadomestil ali drugih plačil za opravljeno delo dlje kot tri mesece.

Odstotek populacije med 18. in 64. letom, ki so trenutno lastniki in managerji novega podjetja, to pomeni, da so lastniki in hkrati vodijo podjetje, ki je izplačevalo plače, nadomestila ali druga plačila za opravljeno delo več kot tri mesece, a manj kot 42 mesecev.

Odstotek populacije med 18. in 64. letom, ki so bodisi nastajajoči bodisi novi podjetniki (lastniki in menedžerji) novega podjetja.

Odstotek populacije med 18 . in 64. letom, ki so trenutno podjetniki ustaljenega podjetja; to pomeni, da so lastniki in hkrati vodijo podjetje, ki je izplačevalo plače, nadomestila ali druga plačila za opravljeno delo več kot 42 mesecev.

Odstotek populacije med 18 . in 64 . letom, ki so bodisi vključeni v zgodnje podjetniške aktivnosti ali pa so lastniki in menedžerji ustaljenega podjetja (kot je opredeljeno zgoraj).

Odstotek populacije med 18. in 64. letom, ki so prekinili s podjetništvom, poslovanje podjetja pa se nadaljuje.

Odstotek populacije med 18. in 64. letom, ki so prekinili s podjetništvom, poslovanje podjetja je prenehalo.

Odstotek populacije med 18. in 64. letom, ki so v zadnjih 12 mesecih prenehali poslovati, ker so podjetje prodali ali zaprli ali pa kako drugače prekinili svoj lastniško-mendžerski odnos s podjetjem. Opozorilo: to NI merilo stopnje propada podjetij.

Odstotek podjetnikov, ki so v preteklem letu opustili poslovanje, $v$ primerjavi s celotno podjetniško aktivnostjo.

Odstotek populacije med 18 . in 64 . letom, ki so trenutno vključeni v razvoj nove podjetniške dejavnosti za svojega delodajalca in imajo pri tem udejstvovanju vodilno vlogo.

Odstotek populacije med 18. in 64. letom, ki so bodisi nastajajoči bodisi novi podjetniki (lastniki in managerji) novega podjetja, ki ima zastavljen socialni cilj.

Odstotek populacije med 18. in 64. letom, ki so vključeni v zgodnje podjetništvo in (a) imajo v lasti in vodijo vsaj del podjetja skupaj z družinskimi člani ali (b) imajo podjetje v samostojni lasti, a ga upravljajo skupaj s člani družine.

Odstotek populacije med 18 . in 64. letom, ki so dobili prejemke iz plačanega dela, ki so ga pridobili preko digitalne platforme.

Odstotek populacije med 18 . in 64. letom, ki so dobili prejemke iz posojanja ali dajanja v najem svojih dobrin ali lastnine ali iz privoljenja dostopa do storitev, ki jih zagotavljajo preko digitalne platforme. 
Podjetniške aspiracije (Entrepreneurial aspirations)

Zgodnja podjetniška aktivnost s pričakovano visoko rastjo zaposlovanja (Growth expectation entrepreneurial activity)

Delež inovativnih zgodnjih podjetnikov (Percentage of respondents within TEA: reporting some new product/ market combination)

\section{Mednarodno usmerjena zgodnja podjetniška aktivnost (relativni delež) (International oriented entrepreneurial activity)}

Okolje: lokalno - nacionalno mednarodno

(Scope: local - national - international)

\section{Vpliv izdelkov/storitev: lokalno - nacionalno - mednarodno (Product/Service Impact: local - national - international)}

\section{Vpliv tehnologije/postopkov: lokalno - nacionalno - mednarodno (Technology/Procedures Impact: local - national - international)}

\section{Neformalno investiranje} (Informal Investment)
Odstotek populacije med 18 . in 64. letom, ki so bodisi nastajajoči bodisi novi podjetniki (lastniki in menedžerji), ki pričakujejo, da bodo čez pet let zaposlovali določeno dodatno število ljudi.

Odstotek zgodnjih podjetnikov (nastajajočih in novih), ki izjavljajo, da imajo neko novo kombinacijo produkta in trga.

Odstotek zgodnjih podjetnikov (nastajajočih in novih), ki navajajo, da je vsaj $25 \%$ njihovih prihodkov iz drugih držav.

Odstotek populacije med 18. in 64. letom, vključene v TEA, s kupci bodisi samo v njihovem lokalnem okolju, samo znotraj države ali mednarodno.

Odstotek populacije med 18. in 64. letom, vključene v TEA, z izdelki ali storitvami, ki so bodisi novi v njihovem lokalnem okolju, novi znotraj države ali novi za svet.

Odstotek populacije med 18 . in 64. letom, vključene v TEA, s tehnologijo ali postopki, ki so bodisi novi v njihovem lokalnem okolju, novi znotraj države ali novi za svet.

Odstotek populacije med 18. in 64. letom, ki je v zadnjih treh letih investirala v podjetje nekoga drugega.

\section{S pandemijo povezane mere (Pandemic-related indicators)}

\section{Vpliv na dohodek gospodinjstva \\ (Household Income Impact)}

\section{Poznavanje podjetnika, ki je prenehal poslovati \\ (Knowing an Entrepreneur Who Stopped a Business)}

Poznavanje podjetnika, ki je ustanovil podjetje (Knowing an Entrepreneur Who Started a Business)

\section{Priložnosti zaradi pandemije (Pandemic Opportunities)}

Odstotek odraslih, starih 18-64 let, ki menijo, da je pandemija povzročila, da se je dohodek njihovega gospodinjstva nekoliko ali močno zmanjšal.

Odstotek odraslih, starih 18-64 let, ki poznajo nekoga, ki je prenehal poslovati zaradi pandemije.

Odstotek odraslih, starih 18-64 let, ki poznajo nekoga, ki je ustanovil podjetje zaradi pandemije.

Odstotek anketirancev s TEA, ki se strinjajo ali se popolnoma strinjajo, da je pandemija ponudila nove priložnosti, ki jih želijo izkoristiti. 


\section{GEM-ovi okvirni pogoji za podjetništvo, NES}

Finančna podpora za
podjetnike

Vladni programi za podjetništvo

Izobraževanje in
usposabljanje za
podjetništvo - na ravni OŠ
in SS

Dostopnost in učinkovitost kapitalskih trgov ter razpoložljivost različnih finančnih virov za podjetnike - lastniški in dolžniški viri financiranja - za MSP, vključno z garancijami in subvencijami ter množičnim financiranjem.

Podpora in ustreznost vladnih politik; v kolikšnem obsegu je podjetništvo pomembno gospodarsko vprašanje (ocena vladne podpore za MSP).

Davki in predpisi spodbujajo nova podjetja in MSP-je ali pa predstavljajo breme za zagon in rast podjetij (ocena vladne regulative, na primer davki in drugi predpisi za MSP ter birokratske ovire).

Prisotnost in kakovost vladnih programov, ki ustvarjajo pogoje za razvoj podjetništva (spodbuda za MSP), na vseh vladnih ravneh (nacionalni, regionalni, občinski), vključno s subvencijami, inkubatorji in agencijami, ki podjetnike ocenjujejo in jim svetujejo.

V kolikšnem obsegu je usposabljanje za ustanavljanje in vodenje MSP vključeno v izobraževanje in usposabljanje v osnovnih in srednjih šolah; vključenost podjetniških tem v šolske programe ter spodbujanje/oblikovanje podjetniških vrednot.

\section{Izobraževanje in usposabljanje za podjetništvo - po SŠ}

Prenos raziskav in razvoja

\section{Poslovna in strokovna infrastruktura}

Notranji trg - dinamičnost

Notranji trg - odprtost, bremena

Fizična infrastruktura

Kulturne in družbene norme
V kolikšnem obsegu je usposabljanje za ustanavljanje in vodenje MSP vključeno v izobraževanje in usposabljanje po srednji šoli (poklicno izobraževanje, fakultete, poslovne šole itd.); vključuje učinkovitost izobraževalnih sistemov pri gradnji podjetniških veščin in oblikovanju podjetniških vrednot pri študentih.

$\checkmark$ kolikšnem obsegu nacionalne raziskave in razvoj vodijo do novih poslovnih priložnosti in so na voljo MSP (obstoj in učinkovitost različnih mehanizmov za prenos raziskovalnih dosežkov in tehnologije z univerz in raziskovalnih centrov $v$ podjetniško prakso).

Kakovost in dostopnost poslovne, pravne in strokovne infrastrukture, ki jo potrebujejo MSP (lastninske pravice, poslovna infrastruktura, računovodske, pravne in druge storitve, ki podpirajo ali spodbujajo MSP).

Stopnja spremembe trga iz leta v leto; obstoj prostega in odprtega trga, na katerem noben subjekt nima moči, da vpliva na cene ali jih določa, in na katerem spremembe povpraševanja spremljajo spremembe ponudbe in obratno.

Obremenitve na notranjem trgu oziroma v kolikšni meri lahko nova podjetja prosto vstopijo na obstoječa tržišča, vključno s predpisi, ki lahko ta prizadevanja olajšajo.

Enostaven dostop do razpoložljive fizične infrastrukture, potrebne za poslovanje podjetij (na primer komunikacije, komunalne storitve, ceste, železnice, pristanišča, letališča, zemljišče/zgradbe ali prostor), po ceni, ki ne diskriminira MSP.

V kolikšnem obsegu kulturne in družbene norme spodbujajo ali zavirajo dejavnosti, ki vodijo do novih poslov, metod ali dejavnosti, ki lahko potencialno povečajo osebno premoženje in dohodek; osredotočenost družbe na podjetništvo z vedenjem, prepričanji, jezikom in običaji. 


\section{Podatkovne tabele}

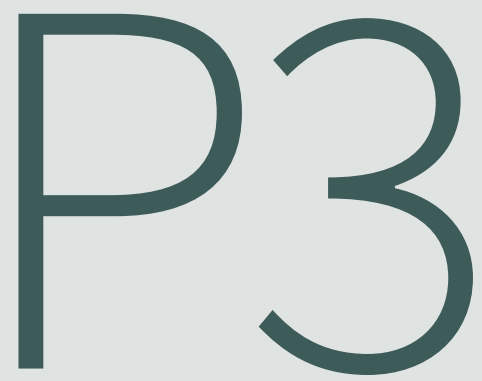

Tabela 1: Elementi podjetniške zmogljivosti in zaznavanja odnosa do podjetništva v družbi, GEM 2020, APS

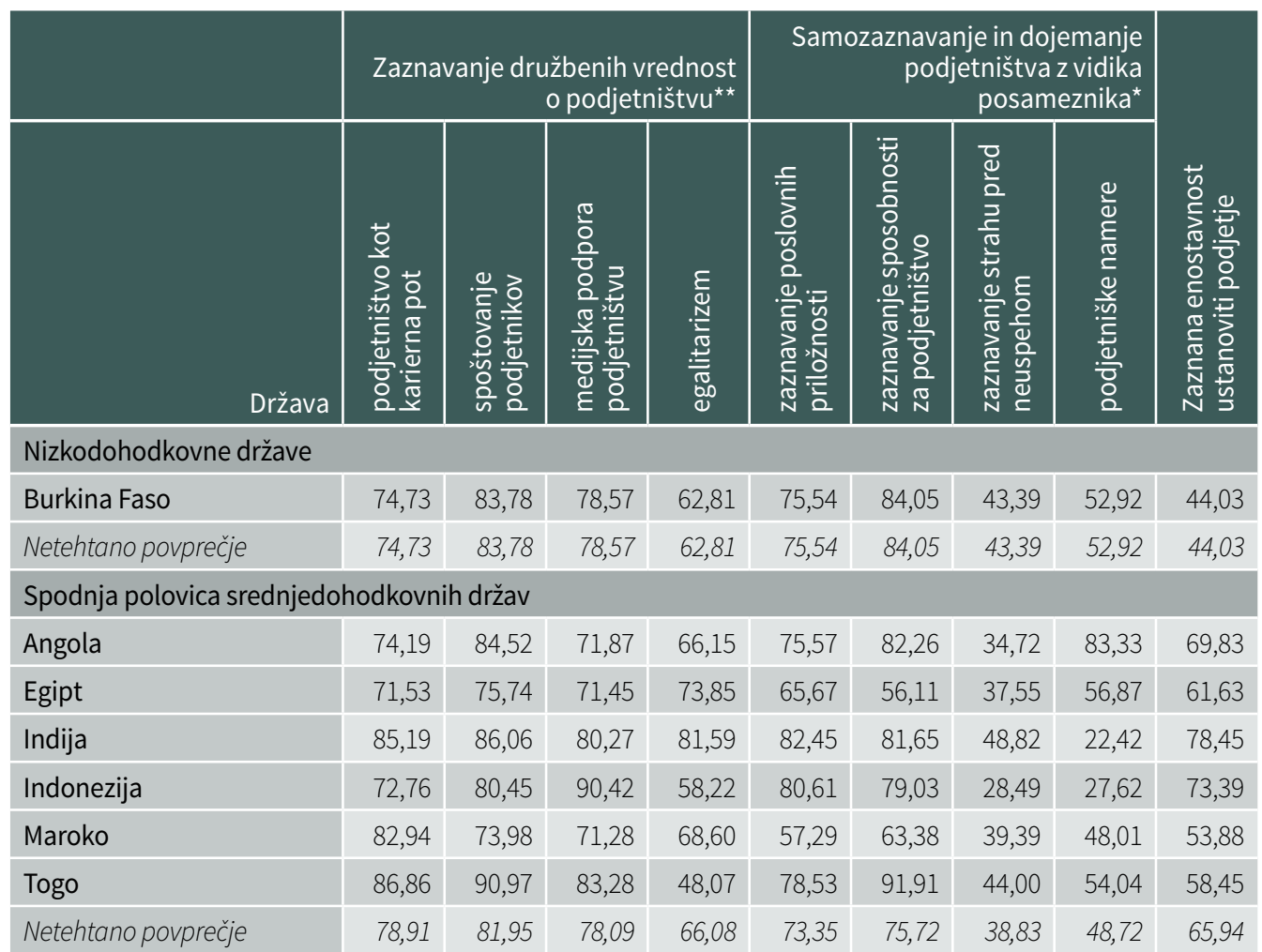




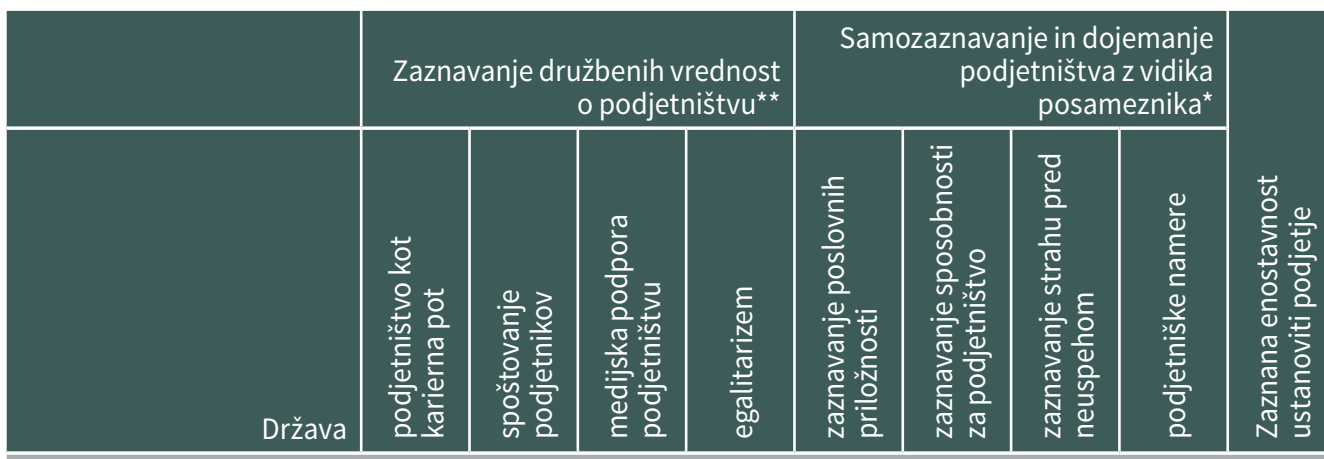

Zgornja polovica srednjedohodkovnih držav

\begin{tabular}{|c|c|c|c|c|c|c|c|c|c|}
\hline Brazilija & & & & & 57,31 & 67,84 & 47,03 & 50,61 & 41,38 \\
\hline Gvatemala & 94,26 & 78,60 & 61,45 & 63,81 & 62,65 & 74,42 & 40,96 & 50,00 & 48,79 \\
\hline Iran & 47,34 & 94,31 & 65,25 & 65,35 & 13,32 & 64,86 & 39,86 & 24,53 & 21,27 \\
\hline Kazahstan & 90,69 & 91,73 & 62,48 & 93,62 & 44,79 & 63,75 & 18,10 & 62,64 & 51,06 \\
\hline Rusija & 75,30 & 72,50 & 60,99 & 71,11 & 33,45 & 34,51 & 46,94 & 11,38 & 30,60 \\
\hline Netehtano povprečje & 76,90 & 84,29 & 62,54 & 73,47 & 42,30 & 61,08 & 38,58 & 39,83 & 38,62 \\
\hline
\end{tabular}

Visokodohodkovne države

\begin{tabular}{|c|c|c|c|c|c|c|c|c|c|}
\hline Avstrija & 44,52 & 79,76 & 70,03 & 60,13 & 31,21 & 53,30 & 44,49 & 6,96 & 47,50 \\
\hline Čile & & & & & 46,69 & 71,69 & 50,53 & 51,92 & 46,09 \\
\hline Ciper & 76,65 & 70,65 & 61,83 & 55,62 & 21,10 & 58,10 & 55,83 & 22,65 & 49,67 \\
\hline Grčija & 69,52 & 70,26 & 57,24 & 57,97 & 27,90 & 53,25 & 62,83 & 12,63 & 25,87 \\
\hline Hrvaška & 59,29 & 53,47 & 58,39 & 76,41 & 47,15 & 74,99 & 55,40 & 30,45 & 30,72 \\
\hline Italija & & & & & 62,21 & 60,84 & 27,08 & 4,61 & 78,05 \\
\hline Izrael & 60,71 & 83,70 & 53,13 & 40,18 & 25,03 & 37,67 & 56,10 & 22,87 & 12,27 \\
\hline Južna Koreja & 56,61 & 87,69 & 70,58 & 70,97 & 44,64 & 53,01 & 20,29 & 34,35 & 33,94 \\
\hline Kanada & 71,78 & 81,34 & 76,95 & 76,91 & 49,11 & 55,62 & 57,47 & 17,72 & 67,71 \\
\hline Katar & 81,30 & 88,29 & 82,04 & 68,28 & 72,25 & 68,24 & 41,42 & 52,40 & 67,94 \\
\hline Kolumbija & 53,54 & 58,28 & 60,38 & 42,92 & 47,89 & 64,80 & 42,49 & 43,28 & 33,18 \\
\hline Kuvajt & & & & & 62,63 & 63,38 & 50,80 & 62,11 & 64,53 \\
\hline Latvija & 56,70 & 61,84 & 63,46 & 49,11 & 37,07 & 55,31 & 40,79 & 22,63 & 33,22 \\
\hline Luksemburg & & & & 52,24 & 41,92 & 45,73 & 48,68 & 14,52 & 63,79 \\
\hline Nemčija & 54,88 & 81,82 & 53,66 & 63,16 & 36,02 & 47,58 & 38,40 & 12,66 & 54,36 \\
\hline Nizozemska & & & & & 48,76 & 43,58 & 37,38 & 17,08 & 82,85 \\
\hline Norveška & & & & & 56,97 & 41,58 & 29,51 & 7,10 & 84,09 \\
\hline Oman & 81,35 & 90,22 & 89,01 & 62,26 & 83,79 & 64,46 & 42,62 & 60,61 & 67,78 \\
\hline Panama & 67,04 & 65,82 & 72,44 & 52,69 & 47,21 & 72,67 & 41,30 & 56,65 & 55,87 \\
\hline Poljska & 59,89 & 60,14 & 41,02 & 50,99 & 51,62 & 60,04 & 40,27 & 6,12 & 58,85 \\
\hline Saudova Arabija & 93,70 & 95,11 & 92,93 & & 90,49 & 86,44 & 48,49 & 33,01 & 91,47 \\
\hline Slovaška & 49,30 & 62,12 & 56,26 & 66,72 & 40,91 & 56,38 & 46,79 & 19,90 & 26,00 \\
\hline
\end{tabular}




\begin{tabular}{|c|c|c|c|c|c|c|c|c|c|}
\hline \multirow[b]{2}{*}{ Država } & \multicolumn{4}{|c|}{$\begin{array}{r}\text { Zaznavanje družbenih vrednost } \\
\text { o podjetništvu** }\end{array}$} & \multicolumn{4}{|c|}{$\begin{array}{r}\text { Samozaznavanje in dojemanje } \\
\text { podjetništva z vidika } \\
\text { posameznika* }\end{array}$} & \multirow[b]{2}{*}{ 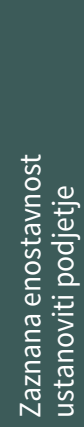 } \\
\hline & 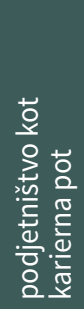 & 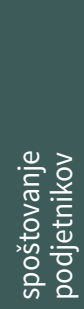 & 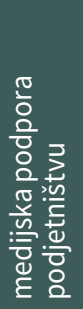 & 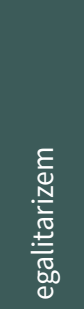 & 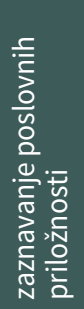 & 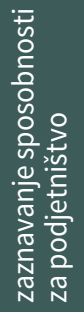 & 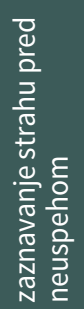 & 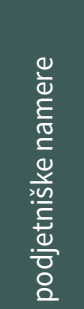 & \\
\hline Slovenija & 68,67 & 85,06 & 81,3 & 81,28 & 42,03 & 59,4 & 48,22 & 13,27 & 62,03 \\
\hline Španija & 56,74 & 61,14 & 50,21 & 67,73 & 16,48 & 51,87 & 63,98 & 6,99 & 34,62 \\
\hline Švedska & & & & & 62,49 & 52,09 & 46,43 & 10,60 & 80,07 \\
\hline Švica & 49,30 & 71,92 & 67,94 & 55,32 & 26,72 & 44,52 & 45,46 & 10,11 & 55,54 \\
\hline Tajvan & 49,75 & 60,40 & 79,50 & 77,22 & 39,25 & 44,81 & 42,04 & 17,37 & 42,48 \\
\hline Urugvaj & 65,40 & 64,19 & 62,42 & 63,79 & 47,27 & 65,60 & 51,15 & 37,31 & 39,41 \\
\hline Velika Britanija & 69,63 & 77,10 & 69,21 & & 27,34 & 54,51 & 56,19 & 10,40 & 69,80 \\
\hline Združene države Amerike & 70,31 & 78,33 & 71,81 & 47,57 & 48,61 & 64,00 & 50,53 & 18,55 & 68,55 \\
\hline Združeni arabski emirati & 74,97 & 84,11 & 80,80 & 79,46 & 62,06 & 54,70 & 42,07 & 36,22 & 69,52 \\
\hline Netehtano povprečje & 64,23 & 73,87 & 67,61 & 61,69 & 46,61 & 57,42 & 45,97 & 24,94 & 54,77 \\
\hline
\end{tabular}


Tabela 2: Vključenost prebivalstva v posamezne faze podjetniškega procesa, GEM 2020, APS
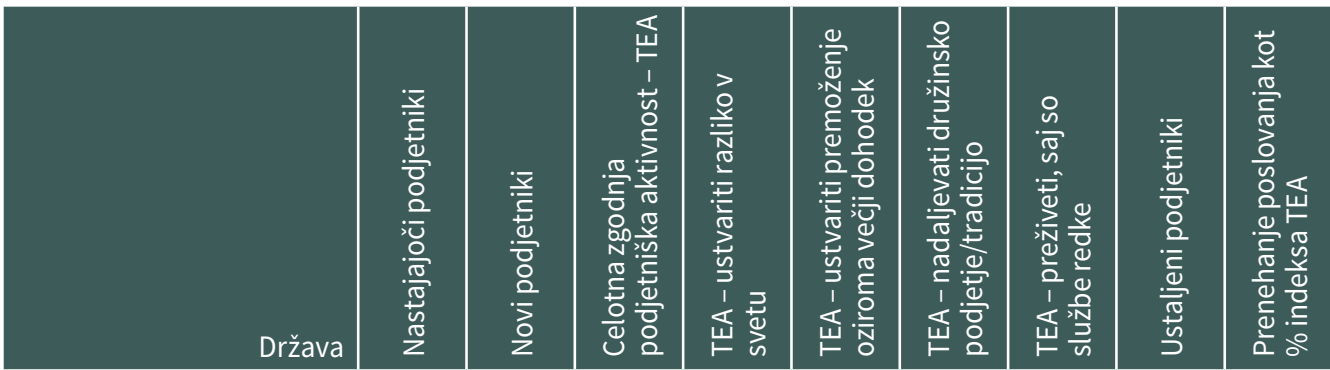

\section{Nizkodohodkovne države}

\begin{tabular}{|l|r|r|r|r|r|r|r|r|r|}
\hline Burkina Faso & 11,54 & 12,00 & 22,98 & 21,35 & 76,14 & 34,01 & 79,36 & 12,41 & 4,16 \\
\hline Netehtano povprečje & 11,54 & 12,00 & 22,98 & 21,35 & 76,14 & 34,01 & 79,36 & 12,41 & 4,16 \\
\hline
\end{tabular}

Spodnja polovica srednjedohodkovnih držav

\begin{tabular}{|l|r|r|r|r|r|r|r|r|r|}
\hline Angola & 27,26 & 24,25 & 49,62 & 65,29 & 63,79 & 37,29 & 89,46 & 9,20 & 38,74 \\
\hline Egipt & 4,91 & 6,65 & 11,27 & 49,18 & 62,85 & 38,13 & 54,03 & 5,23 & 11,16 \\
\hline Indija & 3,17 & 2,27 & 5,34 & 80,70 & 74,69 & 76,78 & 87,31 & 5,88 & 4,74 \\
\hline Indonezija & 2,51 & 7,15 & 9,57 & 44,74 & 49,77 & 41,82 & 71,43 & 11,39 & 4,47 \\
\hline Maroko & 3,03 & 4,14 & 7,11 & 11,80 & 45,20 & 21,37 & 72,80 & 6,79 & 5,96 \\
\hline Togo & 21,71 & 11,68 & 32,89 & 36,89 & 85,50 & 32,55 & 84,58 & 17,79 & 9,33 \\
\hline Netehtano povprečje & 10,43 & 9,36 & 19,30 & 48,10 & 63,63 & 41,32 & 76,60 & 9,38 & 12,40 \\
\hline
\end{tabular}

Zgornja polovica srednjedohodkovnih držav

\begin{tabular}{|l|r|r|r|r|r|r|r|r|r|}
\hline Brazilija & 10,19 & 13,44 & 23,43 & 65,55 & 57,70 & 27,44 & 81,86 & 8,65 & 11,54 \\
\hline Gvatemala & 12,43 & 16,44 & 28,32 & 76,74 & 54,84 & 46,87 & 91,05 & 12,30 & 7,99 \\
\hline Iran & 4,23 & 3,81 & 8,01 & 30,05 & 88,92 & 19,03 & 64,82 & 14,54 & 4,12 \\
\hline Kazahstan & 12,10 & 8,47 & 20,09 & 0,37 & 94,90 & 8,56 & 39,95 & 4,26 & 16,70 \\
\hline Rusija & 3,95 & 4,56 & 8,46 & 24,21 & 68,65 & 16,53 & 71,38 & 4,68 & 3,32 \\
\hline Netehtano povprečje & 8,58 & 9,34 & 17,66 & 39,38 & 73,00 & 23,69 & 69,81 & 8,89 & 8,73 \\
\hline Visokodohodkovne države & & & & & & & & \\
\hline Avstrija & 4,10 & 2,17 & 6,18 & 38,97 & 33,37 & 21,07 & 49,27 & 7,77 & 2,73 \\
\hline Čile & 19,81 & 7,15 & 25,93 & 58,35 & 53,65 & 37,12 & 81,17 & 6,05 & 8,68 \\
\hline Ciper & 5,09 & 3,56 & 8,55 & 37,48 & 85,21 & 21,31 & 77,43 & 7,29 & 3,15 \\
\hline Grčija & 3,30 & 5,51 & 8,63 & 26,86 & 45,80 & 35,74 & 68,97 & 14,58 & 3,07 \\
\hline Hrvaška & 9,12 & 3,68 & 12,66 & 38,95 & 46,95 & 28,70 & 69,44 & 4,22 & 4,47 \\
\hline Italija & 0,89 & 1,03 & 1,92 & 26,63 & 95,33 & 26,46 & 82,21 & 2,23 & 0,53 \\
\hline Izrael & 5,12 & 3,64 & 8,51 & 35,63 & 71,16 & 17,48 & 53,62 & 4,18 & 4,06 \\
\hline Južna Koreja & 8,15 & 5,00 & 13,00 & 10,00 & 68,61 & 5,01 & 32,90 & 16,10 & 3,70 \\
\hline Kanada & 8,72 & 7,47 & 15,55 & 66,45 & 64,17 & 39,46 & 66,13 & 7,28 & 8,58 \\
\hline Katar & 11,23 & 6,57 & 17,17 & 37,57 & 77,51 & 27,74 & 56,57 & 6,07 & 7,65 \\
\hline Kolumbija & 18,04 & 13,96 & 31,12 & 62,88 & 61,65 & 37,06 & 76,97 & 5,45 & 8,66 \\
\hline Kuvajt & 11,30 & 8,58 & 19,22 & 40,13 & 75,99 & 30,61 & 59,57 & 5,92 & 12,39 \\
\hline
\end{tabular}




\begin{tabular}{|c|c|c|c|c|c|c|c|c|c|}
\hline Država & 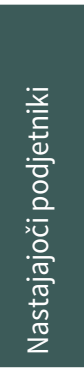 & 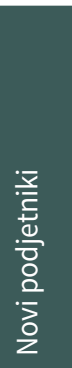 & 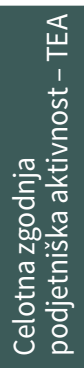 & 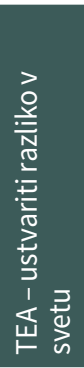 & 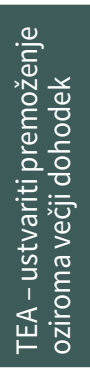 & 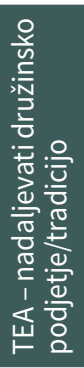 & 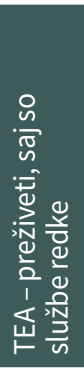 & 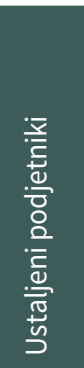 & 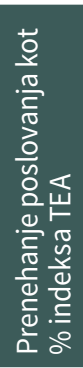 \\
\hline Latvija & 10,14 & 5,80 & 15,60 & 39,77 & 41,81 & 27,53 & 73,58 & 11,08 & 3,02 \\
\hline Luksemburg & 5,65 & 2,40 & 7,96 & 51,07 & 40,29 & 16,63 & 44,29 & 3,56 & 2,55 \\
\hline Nemčija & 3,06 & 1,78 & 4,79 & 39,82 & 52,21 & 62,02 & 45,13 & 6,17 & 2,03 \\
\hline Nizozemska & 6,93 & 4,88 & 11,48 & 46,59 & 40,91 & 24,56 & 47,80 & 6,97 & 5,11 \\
\hline Norveška & 4,70 & 2,94 & 7,64 & 36,66 & 30,13 & 11,83 & 23,14 & 4,08 & 2,04 \\
\hline Oman & 10,41 & 5,90 & 16,01 & 47,93 & 82,23 & 48,92 & 89,75 & 2,49 & 10,82 \\
\hline Panama & 23,02 & 9,84 & 32,35 & 66,56 & 56,27 & 45,29 & 84,71 & 4,09 & 12,91 \\
\hline Poljska & 1,60 & 1,49 & 3,08 & 21,97 & 52,82 & 20,37 & 62,04 & 12,24 & 3,35 \\
\hline Saudova Arabija & 10,81 & 6,66 & 17,27 & 60,78 & 86,87 & 53,18 & 89,45 & 5,11 & 9,22 \\
\hline Slovaška & 10,36 & 3,78 & 13,85 & 33,61 & 38,33 & 32,36 & 73,78 & 6,45 & 5,75 \\
\hline Slovenija & 3,08 & 2,96 & 5,97 & 44,60 & 39,71 & 21,60 & 72,19 & 6,97 & 1,62 \\
\hline Španija & 2,36 & 2,86 & 5,19 & 32,30 & 34,86 & 17,36 & 72,27 & 6,71 & 1,28 \\
\hline Švedska & 4,47 & 2,96 & 7,30 & 41,50 & 42,75 & 24,20 & 28,87 & 6,03 & 3,12 \\
\hline Švica & 6,39 & 3,15 & 9,24 & 42,52 & 32,48 & 20,13 & 52,02 & 6,73 & 1,46 \\
\hline Tajvan & 3,58 & 5,02 & 8,44 & 52,50 & 57,19 & 25,59 & 32,83 & 11,14 & 3,03 \\
\hline Urugvaj & 15,87 & 6,11 & 21,85 & 31,69 & 41,42 & 25,88 & 80,05 & 5,08 & 8,41 \\
\hline Velika Britanija & 5,20 & 2,70 & 7,84 & 57,61 & 59,40 & 20,65 & 54,41 & 6,46 & 2,68 \\
\hline Združene države Amerike & 10,68 & 4,93 & 15,43 & 68,19 & 65,97 & 28,62 & 50,18 & 9,93 & 6,07 \\
\hline Združeni arabski emirati & 7,34 & 8,81 & 15,39 & 52,42 & 77,72 & 47,55 & 74,65 & 2,54 & 9,61 \\
\hline Netehtano povprečje & 8,08 & 4,94 & 12,75 & 43,48 & 56,54 & 29,10 & 62,11 & 6,81 & 5,22 \\
\hline
\end{tabular}


Tabela 3: Izbrani kazalniki iz profila celotne zgodnje podjetniške aktivnosti, GEM 2020, APS
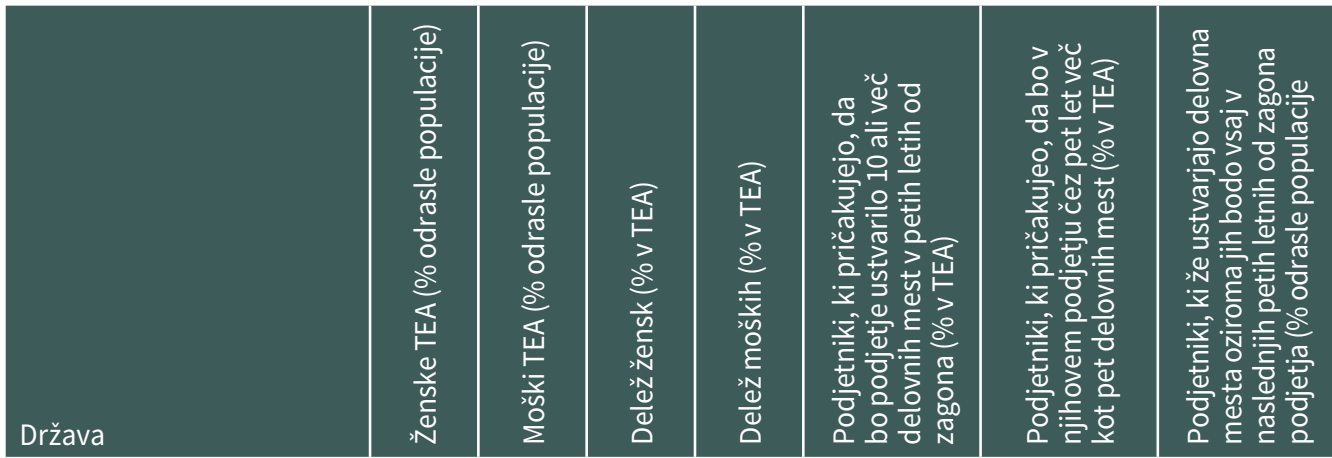

Nizkodohodkovne države

\begin{tabular}{|l|r|r|r|r|r|r|r|}
\hline Burkina Faso & 21,52 & 24,76 & 46,50 & 53,50 & 11,39 & 23,62 & 22,04 \\
\hline Netehtano povprečje & 21,52 & 24,76 & 46,50 & 53,50 & 11,39 & 23,62 & 22,04 \\
\hline
\end{tabular}

Spodnja polovica srednjedohodkovnih držav

\begin{tabular}{|l|r|r|r|r|r|r|r|}
\hline Angola & 51,05 & 48,05 & 51,51 & 48,49 & 23,78 & 36,94 & 37,22 \\
\hline Egipt & 5,44 & 16,73 & 24,54 & 75,46 & 25,04 & 40,76 & 10,34 \\
\hline Indija & 2,62 & 7,94 & 24,81 & 75,19 & 8,68 & 18,73 & 4,45 \\
\hline Indonezija & 10 & 9,14 & 52,25 & 47,75 & 0,73 & 5,36 & 7,97 \\
\hline Maroko & 4,49 & 9,81 & 31,40 & 68,60 & 12,83 & 23,98 & 4,55 \\
\hline Togo & 35,56 & 29,84 & 54,37 & 45,63 & 9,37 & 21,42 & 26,24 \\
\hline Netehtano povprečje & 18,19 & 20,25 & 39,81 & 60,19 & 13,41 & 24,53 & 15,13 \\
\hline
\end{tabular}

Zgornja polovica srednjedohodkovnih držav

\begin{tabular}{|c|c|c|c|c|c|c|c|}
\hline Brazilija & 21,31 & 25,59 & 45,44 & 54,56 & 27,55 & 40,33 & 18,87 \\
\hline Gvatemala & 25,52 & 31,32 & 44,90 & 55,10 & 13,07 & 26,07 & 23,66 \\
\hline Iran & 5,07 & 10,92 & 31,71 & 68,29 & 14 & 19,6 & 6,1 \\
\hline Kazahstan & 20,88 & 19,25 & 52,03 & 47,97 & 12,85 & 40,87 & 14,19 \\
\hline Rusija & 7,28 & 9,74 & 42,77 & 57,23 & 32,82 & 50,13 & 7,79 \\
\hline Netehtano povprečje & 16,01 & 19,36 & 43,37 & 56,63 & 20,06 & 35,40 & 14,12 \\
\hline \multicolumn{8}{|c|}{ Visokodohodkovne države } \\
\hline Avstrija & 5,31 & 7,03 & 43,03 & 56,97 & & 3,37 & 3,6 \\
\hline Čile & 22,08 & 29,9 & 42,48 & 57,52 & 25,49 & 37,23 & 23,57 \\
\hline Ciper & 6,14 & 10,98 & 35,86 & 64,14 & 25,48 & 45,08 & 8,09 \\
\hline Grčija & 6,66 & 10,59 & 38,61 & 61,39 & 6,67 & 16,78 & 6,33 \\
\hline Hrvaška & 9,27 & 16,06 & 36,60 & 63,40 & 17,79 & 22,69 & 8,3 \\
\hline Italija & 0,92 & 2,93 & 23,90 & 76,10 & & 16,89 & 1,17 \\
\hline Izrael & 6,71 & 10,35 & 39,33 & 60,67 & 15,98 & 20,63 & 4,11 \\
\hline Južna Koreja & 10,57 & 15,34 & 40,80 & 59,20 & 23,51 & 37,39 & 11,85 \\
\hline Kanada & 13,89 & 17,25 & 44,61 & 55,39 & 12,86 & 24,33 & 9,83 \\
\hline Katar & 12,32 & 18,36 & 40,16 & 59,84 & 60,12 & 71,86 & 15,06 \\
\hline
\end{tabular}




\begin{tabular}{|c|c|c|c|c|c|c|c|}
\hline Država & 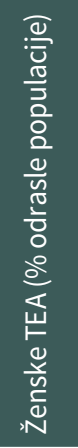 & 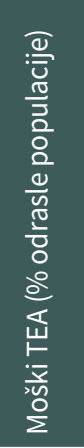 & 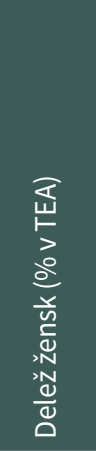 & 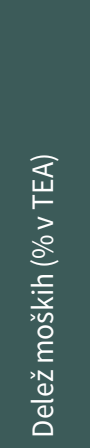 & 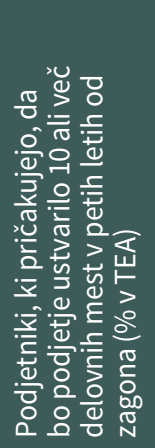 & 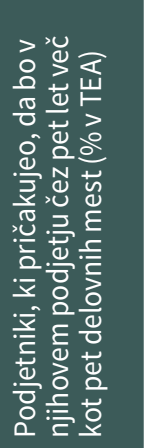 & 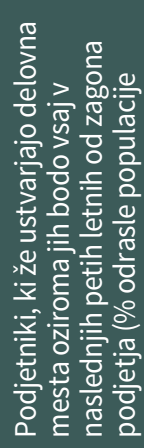 \\
\hline Kolumbija & 30,19 & 32,15 & 48,43 & 51,57 & 40,41 & 58,47 & 29,69 \\
\hline Kuvajt & 16,86 & 20,41 & 45,24 & 54,76 & 39,88 & 53,81 & 15,93 \\
\hline Latvija & 11,17 & 20,04 & 35,79 & 64,21 & 26,34 & 32,13 & 11,75 \\
\hline Luksemburg & 4,94 & 10,86 & 31,27 & 68,73 & 25,5 & 37,95 & 6,12 \\
\hline Nemčija & 4,44 & 5,11 & 46,49 & 53,51 & 23,87 & 29,31 & 3,33 \\
\hline Nizozemska & 9,55 & 13,4 & 41,61 & 58,39 & 9,21 & 15,25 & 7,39 \\
\hline Norveška & 4,92 & 10,23 & 32,48 & 67,52 & 23,12 & 32,48 & 5,02 \\
\hline Oman & 17,31 & 14,73 & 54,03 & 45,97 & 7,44 & 11,46 & 7,78 \\
\hline Panama & 29,09 & 35,57 & 44,99 & 55,01 & 28,23 & 46,43 & 29,95 \\
\hline Poljska & 2,36 & 3,81 & 38,25 & 61,75 & 17,42 & 29,67 & 2,56 \\
\hline Saudova Arabija & 17,67 & 16,97 & 51,01 & 48,99 & 36,65 & 65,18 & 16,57 \\
\hline Slovaška & 8,91 & 18,8 & 32,15 & 67,85 & 24,1 & 31,87 & 9,39 \\
\hline Slovenija & 4,75 & 7,1 & 38,30 & 61,70 & 16,79 & 30,41 & 4,95 \\
\hline Španija & 4,81 & 5,57 & 46,34 & 53,66 & 6,4 & 13,62 & 3,11 \\
\hline Švedska & 4,79 & 9,7 & 33,06 & 66,94 & 12,01 & 20,41 & 4,08 \\
\hline Švica & 8,72 & 9,75 & 47,21 & 52,79 & 8,8 & 12,21 & 6,48 \\
\hline Tajvan & 7,26 & 9,63 & 42,98 & 57,02 & 19,08 & 37,98 & 6,85 \\
\hline Urugvaj & 20,06 & 23,75 & 45,79 & 54,21 & 17,75 & 23,4 & 16,9 \\
\hline Velika Britanija & 6,18 & 9,5 & 39,41 & 60,59 & 14,13 & 19,72 & 4,79 \\
\hline Združene države Amerike & 13,63 & 17,26 & 44,12 & 55,88 & 22,49 & 30,5 & 11,53 \\
\hline Združeni arabski emirati & 12,18 & 16,77 & 42,07 & 57,93 & 55,81 & 79,22 & 15,1 \\
\hline Netehtano povprečje & 10,76 & 14,51 & 40,85 & 59,15 & 22,87 & 32,51 & 10,04 \\
\hline
\end{tabular}





\section{Raziskovalni timi in sponzorji GEM $v$ letu 2020}

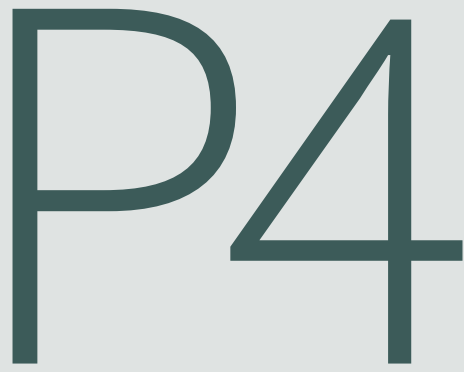

\begin{tabular}{|c|c|c|c|c|}
\hline Tim & Ustanova & Člani tima & Finančni sponzorji & $\begin{array}{l}\text { Izvedba } \\
\text { anketiranja }\end{array}$ \\
\hline Angola & $\begin{array}{l}\text { Sociedade } \\
\text { Portuguesa de } \\
\text { Inovação/Sociedade } \\
\text { Portuguesa } \\
\text { de Inovação/ } \\
\text { Universidade } \\
\text { Católica de Angola }\end{array}$ & $\begin{array}{l}\text { Augusto Medina, } \\
\text { Douglas Thompson, } \\
\text { Salim Abdul Valimamade, } \\
\text { Francisco Rocha }\end{array}$ & $\begin{array}{l}\text { BFA - Banco de Fomento } \\
\text { Angola S.A.R.L. } \\
\text { International Development } \\
\text { Research Centre (IDRC) }\end{array}$ & SINFIC \\
\hline Avstrija & $\begin{array}{l}\text { FH JOANNEUM } \\
\text { University of Applied } \\
\text { Sciences }\end{array}$ & $\begin{array}{l}\text { Christian Friedl, } \\
\text { Rene Wenzel, } \\
\text { Bernadette Frech, } \\
\text { Sara Koren }\end{array}$ & $\begin{array}{l}\text { Federal Ministry of Digital } \\
\text { and Economic Affairs } \\
\text { (BMDW) } \\
\text { Federal Ministry of } \\
\text { Transport, Innovation and } \\
\text { Technology (BMVIT) } \\
\text { Austrian Federal Economic } \\
\text { Chamber (WKO) } \\
\text { Federal Economic } \\
\text { Chamber of Vienna (WKW) } \\
\text { Austrian Council for } \\
\text { Research and Technology } \\
\text { Development (Rat FTE) } \\
\text { Austrian Economic Service } \\
\text { (AWS) } \\
\text { Austrian Research } \\
\text { Promotion Agency (FFG) } \\
\text { Joanneum Research } \\
\text { FH JOANNEUM - } \\
\text { University of Applied } \\
\text { Sciences } \\
\text { B\&C Privatstiftung }\end{array}$ & $\begin{array}{l}\text { Market } \\
\text { Marktforschungs- } \\
\text { Ges.m.b.H. \& } \\
\text { Co.KG }\end{array}$ \\
\hline
\end{tabular}




\begin{tabular}{|c|c|c|c|c|}
\hline Tim & Ustanova & Člani tima & Finančni sponzorji & $\begin{array}{l}\text { Izvedba } \\
\text { anketiranja }\end{array}$ \\
\hline Brazilija & $\begin{array}{l}\text { Instituto Brasileiro } \\
\text { Da Qualidade E } \\
\text { Produtividade (IBQP) }\end{array}$ & $\begin{array}{l}\text { Simara Greco, Erika } \\
\text { Onozato, Paulo Bastos, } \\
\text { Vinicius Larangeiras de } \\
\text { Souza }\end{array}$ & $\begin{array}{l}\text { Serviço Brasileiro de } \\
\text { Apoio às Micro e Pequenas } \\
\text { Empresas (SEBRAE) }\end{array}$ & $\begin{array}{l}\text { Z00M - Agência } \\
\text { de Pesquisas }\end{array}$ \\
\hline $\begin{array}{l}\text { Burkina } \\
\text { Faso }\end{array}$ & CEDRES/LaReGEO & $\begin{array}{l}\text { Florent Song-Naba, } \\
\text { Mamadou Toé, Guimaré } \\
\text { Régis Gouem, Djarius } \\
\text { Bama }\end{array}$ & $\begin{array}{l}\text { Enabel (Belgium } \\
\text { Development Agency) }\end{array}$ & $\begin{array}{l}\text { CEDRES/ } \\
\text { LaReGEO }\end{array}$ \\
\hline Ciper & $\begin{array}{l}\text { University of Cyprus } \\
\text { (UCY), Centre for } \\
\text { Entrepreneurship } \\
\text { (C4E) }\end{array}$ & $\begin{array}{l}\text { Marios Dikaiakos, } \\
\text { Ariana Polyviou, } \\
\text { Pantelitsa Eteokleous }\end{array}$ & $\begin{array}{l}\text { Ministry of Energy, } \\
\text { Commerce and Industry }\end{array}$ & $\begin{array}{l}\text { RAl Consultants } \\
\text { Ltd }\end{array}$ \\
\hline Čile & $\begin{array}{l}\text { Universidad del } \\
\text { Desarrollo }\end{array}$ & $\begin{array}{l}\text { Maribel Guerrero, } \\
\text { Tomás Serey }\end{array}$ & Universidad del Desarrollo & $\begin{array}{l}\text { Questio Estudios } \\
\text { de Mercado y } \\
\text { Opinión }\end{array}$ \\
\hline Egipt & $\begin{array}{l}\text { The American } \\
\text { University in Cairo - } \\
\text { School of Business }\end{array}$ & $\begin{array}{l}\text { Ayman Ismail, Ahmed } \\
\text { Tolba, Shima Barakat, } \\
\text { Hakim Adel Hakim } \\
\text { Meshreki, Seham } \\
\text { Ghalwash }\end{array}$ & $\begin{array}{l}\text { Drosos Foundation } \\
\text { Oxfam Novib (Danish } \\
\text { Arab Partnership } \\
\text { Program - DAPP) } \\
\text { Hivos }\end{array}$ & PHI Knowledge \\
\hline Grčija & $\begin{array}{l}\text { Foundation for } \\
\text { Economic \& } \\
\text { Industrial Research } \\
\text { (FEIR/ IOBE) }\end{array}$ & $\begin{array}{l}\text { Aggelos Tsakanikas, } \\
\text { Sofia Stavraki, Evangelia } \\
\text { Valavanioti, Ioannis } \\
\text { Giotopoulos }\end{array}$ & RAYCAP S.A. & Datapower SA \\
\hline Gvatemala & $\begin{array}{l}\text { Kirzner } \\
\text { Entrepreneurship } \\
\text { Center at Francisco } \\
\text { Marroquín University }\end{array}$ & $\begin{array}{l}\text { Mónica Río-Nevado de } \\
\text { Zelaya, Carolina Uribe, } \\
\text { David Casasola, Josías } \\
\text { López, Estefanía Vizcaíno }\end{array}$ & $\begin{array}{l}\text { Francisco Marroquín } \\
\text { University -UFM- }\end{array}$ & Khanti, S.A. \\
\hline Hrvaška & $\begin{array}{l}\text { J.J. Strossmayer } \\
\text { University in Osijek, } \\
\text { Faculty of Economics } \\
\text { (EFOS) }\end{array}$ & $\begin{array}{l}\text { Slavica Singer, } \\
\text { Nataša Šarlija, } \\
\text { Sanja Pfeifer, Sunčica } \\
\text { Oberman Peterka }\end{array}$ & $\begin{array}{l}\text { Ministry of Economy, } \\
\text { Entrepreneurship and } \\
\text { Crafts } \\
\text { Croatian Association of } \\
\text { Banks } \\
\text { CEPOR - SMEs and } \\
\text { Entrepreneurship Policy } \\
\text { Centre } \\
\text { J.J. Strossmayer University } \\
\text { in Osijek, Faculty of } \\
\text { Economics }\end{array}$ & $\begin{array}{l}\text { Puls d.o.o., } \\
\text { Zagreb }\end{array}$ \\
\hline Indija & $\begin{array}{l}\text { Entrepreneurship } \\
\text { Development } \\
\text { Institute of India } \\
\text { (EDII) }\end{array}$ & $\begin{array}{l}\text { Sunil Shukla, Amit Kumar } \\
\text { Dwivedi, Pankaj Bharti }\end{array}$ & $\begin{array}{l}\text { Centre for Research } \\
\text { in Entrepreneurship } \\
\text { Education and } \\
\text { Development (CREED), } \\
\text { EDIl-Ahmedabad }\end{array}$ & IMRB \\
\hline
\end{tabular}




\begin{tabular}{|c|c|c|c|c|}
\hline Tim & Ustanova & Člani tima & Finančni sponzorji & $\begin{array}{l}\text { Izvedba } \\
\text { anketiranja }\end{array}$ \\
\hline Indonezija & $\begin{array}{l}\text { Parahyangan } \\
\text { Catholic University }\end{array}$ & $\begin{array}{l}\text { Gandhi Pawitan, } \\
\text { Catharina B. } \\
\text { Nawangpalupi, Maria } \\
\text { Widyarini, Agus Gunawan }\end{array}$ & $\begin{array}{l}\text { Parahyangan Catholic } \\
\text { University } \\
\text { Ministry of Research, } \\
\text { Technology, and Higher } \\
\text { Education of the Republic } \\
\text { of Indonesia (under } \\
\text { Applied Research - Higher } \\
\text { Education Excellence } \\
\text { Grant Scheme) }\end{array}$ & Sapa Institute \\
\hline Iran & $\begin{array}{l}\text { Faculty of } \\
\text { Entrepreneurship, } \\
\text { University of Tehran }\end{array}$ & $\begin{array}{l}\text { Abbas Bazargan, } \\
\text { Nezameddin Faghih, } \\
\text { Ali Rezaeian, Abbas } \\
\text { Bazargan, Mohammad } \\
\text { Reza Zali, Jahangir } \\
\text { Yadollahi Farsi, Seyed } \\
\text { Mostafa Razavi, Leyla } \\
\text { Sarfaraz }\end{array}$ & $\begin{array}{l}\text { Faculty of } \\
\text { Entrepreneurship, } \\
\text { University of Tehran }\end{array}$ & $\begin{array}{l}\text { Faculty of } \\
\text { Entrepreneurship }\end{array}$ \\
\hline Italija & $\begin{array}{l}\text { Università } \\
\text { Politecnica delle } \\
\text { Marche }\end{array}$ & $\begin{array}{l}\text { Donato lacobucci, Diego } \\
\text { D’Adda, Alessandra } \\
\text { Micozzi, Francesca Micozzi }\end{array}$ & $\begin{array}{l}\text { Fondazione Aristide } \\
\text { Merloni } \\
\text { Università Politecnica delle } \\
\text { Marche }\end{array}$ & DOXA Spa \\
\hline Izrael & $\begin{array}{l}\text { Ira Center } \\
\text { of Business, } \\
\text { Technology \& } \\
\text { Society, Ben Gurion } \\
\text { University }\end{array}$ & $\begin{array}{l}\text { Ehud Menipaz, } \\
\text { Yoash Avrahami }\end{array}$ & $\begin{array}{l}\text { Ministry of Economics and } \\
\text { Industry, Government of } \\
\text { Israel } \\
\text { Ira Foundation of Business, } \\
\text { Technology and Society }\end{array}$ & $\begin{array}{l}\text { Brandman } \\
\text { Institute }\end{array}$ \\
\hline Japonska & Musashi University & $\begin{array}{l}\text { Noriyuki Takahashi, } \\
\text { Masaaki Suzuki, Yuji } \\
\text { Honjo, Takehiko Yasuda, } \\
\text { Takehiko Isobe }\end{array}$ & $\begin{array}{l}\text { Ministry of Economy, Trade } \\
\text { and Industry (METI) }\end{array}$ & $\begin{array}{l}\text { Social Survey } \\
\text { Research } \\
\text { Information Co. } \\
\text { Ltd (SSRI) }\end{array}$ \\
\hline Kanada & $\begin{array}{l}\text { The Centre for } \\
\text { Innovation Studies } \\
\text { (THECIS) }\end{array}$ & $\begin{array}{l}\text { Peter Josty, Adam } \\
\text { Holbrook, Geoff Gregson, } \\
\text { Blair Winsor, Jacqueline S. } \\
\text { Walsh, Harvey Johnstone, } \\
\text { Kevin McKague, Yves } \\
\text { Bourgeois, Matthew } \\
\text { Pauley, Étienne St-Jean, } \\
\text { Marc Duhamel, Sandra } \\
\text { Schillo, Charles Davis, } \\
\text { Dave Valliere, Howard Lin, } \\
\text { Nathan Greidanus, Chris } \\
\text { Street, Chad Saunders, } \\
\text { Richard Hawkins, Amanda } \\
\text { Williams, Karen Hughes, } \\
\text { Murat Erogul, Brian Wixted }\end{array}$ & $\begin{array}{l}\text { Government of Alberta } \\
\text { Government of Canada } \\
\text { Government of Ontario } \\
\text { Government of the Yukon } \\
\text { Western Economic } \\
\text { Diversification Canada } \\
\text { Women's Economic } \\
\text { Knowledge Hub } \\
\text { (Ryerson University) } \\
\text { Social Sciences and } \\
\text { Humanities Research } \\
\text { Council } \\
\text { University of Manitoba }\end{array}$ & $\begin{array}{l}\text { Elemental Data } \\
\text { Collection Inc. }\end{array}$ \\
\hline Katar & $\begin{array}{l}\text { Qatar Development } \\
\text { Bank (QDB) }\end{array}$ & $\begin{array}{l}\text { Farha Al Kuwari, } \\
\text { Ahmad Hawi }\end{array}$ & $\begin{array}{l}\text { Qatar Development Bank } \\
\text { (QDB) }\end{array}$ & Intelligence Qatar \\
\hline
\end{tabular}




\begin{tabular}{|c|c|c|c|c|}
\hline Tim & Ustanova & Člani tima & Finančni sponzorji & $\begin{array}{l}\text { Izvedba } \\
\text { anketiranja }\end{array}$ \\
\hline Kazahstan & $\begin{array}{l}\text { Nazarbayev } \\
\text { University Graduate } \\
\text { School of Business }\end{array}$ & $\begin{array}{l}\text { Patrick Duparcq, Venkata } \\
\text { Subban Subramanian, } \\
\text { Yerken Turganbayev, } \\
\text { Shumaila Yousafzai, } \\
\text { Bakyt Ospanova, Madina } \\
\text { Nurguzhina, Nurlan } \\
\text { Kulbatyrov, Chingiz Tourez }\end{array}$ & $\begin{array}{l}\text { Nazarbayev University } \\
\text { Graduate School } \\
\text { of Business }\end{array}$ & DATAmetrics \\
\hline Kolumbija & $\begin{array}{l}\text { Consorcio GEM: } \\
\text { Universidad Icesi, } \\
\text { Universidad } \\
\text { Javeriana de Cali, } \\
\text { Universidad del } \\
\text { Norte }\end{array}$ & $\begin{array}{l}\text { Rodrigo Varela Villegas, } \\
\text { Jhon Moreno, Juan David } \\
\text { Soler, Manoj Bayan, } \\
\text { Fernando Pereira, Fabian } \\
\text { Osorio, Eduardo Gomez, } \\
\text { Oscar Suarez, Liyis Gomez, } \\
\text { Alba Corredor, Moises } \\
\text { Galvis, Leon Dario Parra, } \\
\text { Jairo Orozco, Francisco } \\
\text { Matiz, Jose David Peñuela, } \\
\text { Flor Alba Rueda, Piedad } \\
\text { Buelvas }\end{array}$ & $\begin{array}{l}\text { Universidad Icesi } \\
\text { Universidad Javeriana de } \\
\text { Cali } \\
\text { Universidad del Norte } \\
\text { Universidad EAN } \\
\text { Universidad } \\
\text { Cooperativa de } \\
\text { Colombia-Bucaramanga } \\
\text { Corporación Universitaria } \\
\text { Americana } \\
\text { Corporación Universitaria } \\
\text { del Caribe }\end{array}$ & $\begin{array}{l}\text { INFO } \\
\text { Investigaciones } \\
\text { S.A.S. }\end{array}$ \\
\hline Kuvajt & $\begin{array}{l}\text { Box Hill College } \\
\text { Kuwait }\end{array}$ & $\begin{array}{l}\text { Hasan Ghura, Arezou } \\
\text { Harraf, Alicia Coduras, } \\
\text { Arezou Harraf, Wael } \\
\text { Abdallah, Manar Al-Otaibi, } \\
\text { Sharifa Hamada, Carol Bim }\end{array}$ & $\begin{array}{l}\text { Kuwait Foundation for the } \\
\text { Advancement of Sciences } \\
\text { (KFAS) }\end{array}$ & $\begin{array}{l}\text { ARA Research } \\
\text { and Consultancy }\end{array}$ \\
\hline Latvija & $\begin{array}{l}\text { Stockholm School } \\
\text { of Economics in Riga } \\
\text { (SSE Riga) }\end{array}$ & $\begin{array}{l}\text { Marija Krumina, } \\
\text { Anders Paalzow }\end{array}$ & $\begin{array}{l}\text { Stockholm School of } \\
\text { Economics in Riga (SSE } \\
\text { Riga) }\end{array}$ & SKDS \\
\hline Luksemburg & STATEC Research & $\begin{array}{l}\text { Cesare A.F. Riillo, } \\
\text { Chiara Peroni, } \\
\text { Steinn Steinsson }\end{array}$ & $\begin{array}{l}\text { Ministry of the Economy } \\
\text { of the Grand Duchy of } \\
\text { Luxembourg } \\
\text { House of Entrepreneurship } \\
\text { (an initiative of the } \\
\text { Chamber of Commerce } \\
\text { and the Ministry of the } \\
\text { Economy of the Grand } \\
\text { Duchy of Luxembourg) }\end{array}$ & TNS ILRES \\
\hline Maroko & $\begin{array}{l}\text { Entrepreneurship } \\
\text { Research Laboratory } \\
\text { Faculty of Law, } \\
\text { Economics and } \\
\text { Social Sciences } \\
\text { University of Hassan } \\
\text { ॥ Casablanca }\end{array}$ & $\begin{array}{l}\text { Khalid El Ouazani, } \\
\text { Abdellatif Komat, } \\
\text { Salah Koubaa, Fatima } \\
\text { Boutaleb, Hind Malainine, } \\
\text { Sara Yassine }\end{array}$ & $\begin{array}{l}\text { University of Hassan II } \\
\text { Casablanca }\end{array}$ & ClaireVision \\
\hline
\end{tabular}




\begin{tabular}{|c|c|c|c|c|}
\hline Tim & Ustanova & Člani tima & Finančni sponzorji & $\begin{array}{l}\text { Izvedba } \\
\text { anketiranja }\end{array}$ \\
\hline Mehika & $\begin{array}{l}\text { Instituto Tecnológico } \\
\text { y de Estudios } \\
\text { Superiores de } \\
\text { Monterrey } \\
\text { (ITESM) (A.K.A. } \\
\text { Tecnológico de } \\
\text { Monterrey) }\end{array}$ & $\begin{array}{l}\text { Hugo Garza Medina, José } \\
\text { Ernesto Amorós, Elvira } \\
\text { Naranjo, José Manuel } \\
\text { Aguirre, Marcia Campos, } \\
\text { Rafaela Bueckmann } \\
\text { Diegoli, Ján Rehák, } \\
\text { Patricia Esther Alonso } \\
\text { Galicia, Edgar Muñiz Ávila, } \\
\text { Lucía Rodriguez Aceves, } \\
\text { José Manuel Saiz Álvarez, } \\
\text { Margarita Herrera Avilés, } \\
\text { Lizbeth González Tamayo, } \\
\text { Rafael A. Tristán }\end{array}$ & $\begin{array}{l}\text { Instituto Tecnológico y de } \\
\text { Estudios Superiores de } \\
\text { Monterrey } \\
\text { (ITESM) (A.K.A. Tecnológico } \\
\text { de Monterrey) }\end{array}$ & $\begin{array}{l}\text { Berumen y } \\
\text { Asociados S.A. } \\
\text { de C.V. }\end{array}$ \\
\hline Nemčija & $\begin{array}{l}\text { Leibniz University } \\
\text { Hannover - Institute } \\
\text { of Economic and } \\
\text { Cultural Geography }\end{array}$ & $\begin{array}{l}\text { Rolf Sternberg, Armin } \\
\text { Baharian, Johannes von } \\
\text { Bloh, Natalia Gorynia } \\
\text { Pfeffer, Lennard Stolz, } \\
\text { Matthias Wallisch }\end{array}$ & RKW Competence Centre & $\begin{array}{l}\text { uzbonn- } \\
\text { Gesellschaft } \\
\text { für empirische } \\
\text { Sozialforschung } \\
\text { und Evaluation }\end{array}$ \\
\hline Nizozemska & Panteia & $\begin{array}{l}\text { Jacqueline Snijders, Paul } \\
\text { van der Zeijden, Jan de } \\
\text { Kok, Amber van der Graaf, } \\
\text { Ton Geerts }\end{array}$ & $\begin{array}{l}\text { The Ministry of Economic } \\
\text { Affairs and Climate Policy } \\
\text { of the Netherlands }\end{array}$ & Panteia \\
\hline Norveška & $\begin{array}{l}\text { Nord University } \\
\text { Business School }\end{array}$ & $\begin{array}{l}\text { Gry Agnete Alsos, Bjørn } \\
\text { Willy Amo, Tommy } \\
\text { Høyvarde Clausen, Are } \\
\text { Jensen, Espen Isaksen, } \\
\text { Iselin Kristine Mauseth } \\
\text { Steira }\end{array}$ & $\begin{array}{l}\text { Innovation Norway } \\
\text { The Norwegian Ministry } \\
\text { of Trade, Industry, and } \\
\text { Fisheries } \\
\text { Nord University Business } \\
\text { School }\end{array}$ & Polarfakta AS \\
\hline Oman & University of Nizwa & $\begin{array}{l}\text { Abdallah Mohammed } \\
\text { Ishukaili, Bader } \\
\text { Alsuleimani, Norizan } \\
\text { Mohd Kassim, Zunaith } \\
\text { Ahmed, Swadhin Kumar } \\
\text { Mondal, Yasmeen Kausar }\end{array}$ & University of Nizwa & $\begin{array}{l}\text { Horizons } \\
\text { Statistical } \\
\text { Consulting }\end{array}$ \\
\hline Panama & $\begin{array}{l}\text { City of Knowledge } \\
\text { Foundation }\end{array}$ & $\begin{array}{l}\text { Carla Donalicio, Alejandro } \\
\text { Carbonell }\end{array}$ & $\begin{array}{l}\text { AMPYME (Micro, Small } \\
\text { and Medium Enterprise } \\
\text { Authority of Panama) }\end{array}$ & IPSOS \\
\hline Poljska & $\begin{array}{l}\text { Polish Agency } \\
\text { for Enterprise } \\
\text { Development (PARP) }\end{array}$ & $\begin{array}{l}\text { Anna Tarnawa, Melania } \\
\text { Nieć, Joanna Orłowska, } \\
\text { Anna Skowrońska, } \\
\text { Paulina Zadura, Robert } \\
\text { Zakrzewski, Przemysław } \\
\text { Zbierowski }\end{array}$ & $\begin{array}{l}\text { Ministry of Economic } \\
\text { Development } \\
\text { University of Economics in } \\
\text { Katowice }\end{array}$ & $\begin{array}{l}\text { Centrum Badań } \\
\text { Marketingowych } \\
\text { INDICATOR Sp. } \\
\text { z o.o. }\end{array}$ \\
\hline Portoriko & $\begin{array}{l}\text { University of Puerto } \\
\text { Rico (UPR) }\end{array}$ & $\begin{array}{l}\text { Marinés Aponte, Marta } \\
\text { Álvarez, Manuel Lobato }\end{array}$ & $\begin{array}{l}\text { University of Puerto Rico } \\
\text { (UPR) }\end{array}$ & $\begin{array}{l}\text { Gaither } \\
\text { International, Inc }\end{array}$ \\
\hline $\begin{array}{l}\text { Republika } \\
\text { Koreja }\end{array}$ & $\begin{array}{l}\text { Korea } \\
\text { Entrepreneurship } \\
\text { Foundation (KoEF) }\end{array}$ & $\begin{array}{l}\text { Gihyun Kum, Dohyeon } \\
\text { Kim, Chaewon Lee, } \\
\text { Byungheon Lee, } \\
\text { Choonwoo Lee, Yunsoo } \\
\text { Choi, Myoung-jong Lee }\end{array}$ & $\begin{array}{l}\text { Ministry of SMEs and } \\
\text { Startups }\end{array}$ & Max Research \\
\hline
\end{tabular}




\begin{tabular}{|c|c|c|c|c|}
\hline Tim & Ustanova & Člani tima & Finančni sponzorji & $\begin{array}{l}\text { Izvedba } \\
\text { anketiranja }\end{array}$ \\
\hline Rusija & $\begin{array}{l}\text { Graduate School } \\
\text { of Management, } \\
\text { St. Petersburg } \\
\text { University }\end{array}$ & $\begin{array}{l}\text { Olga R. Verkhovskaya, } \\
\text { Karina A. Bogatyreva, } \\
\text { Dmitri Knatko, Maria V. } \\
\text { Dorokhina, Eleonora V. } \\
\text { Shmeleva }\end{array}$ & Sberbank & Levada-Center \\
\hline $\begin{array}{l}\text { Saudova } \\
\text { Arabija }\end{array}$ & $\begin{array}{l}\text { Prince Mohammad } \\
\text { Bin Salman College } \\
\text { of Business and } \\
\text { Entrepreneurship } \\
\text { (MBSC) } \\
\text { Babson Global } \\
\text { Center for } \\
\text { Entrepreneurial } \\
\text { Leadership (BGCEL) }\end{array}$ & $\begin{array}{l}\text { Muhammad Azam Roomi, } \\
\text { Alicia Coduras Martínez, } \\
\text { Donna Kelley }\end{array}$ & $\begin{array}{l}\text { Babson Global Center for } \\
\text { Entrepreneurial Leadership } \\
\text { (BGCEL) }\end{array}$ & $\begin{array}{l}\text { Field Interactive } \\
\text { MR }\end{array}$ \\
\hline Slovaška & $\begin{array}{l}\text { Comenius University } \\
\text { in Bratislava, Faculty } \\
\text { of Management } \\
\text { (UNIBA SK) }\end{array}$ & $\begin{array}{l}\text { Anna Pilková, Marian } \\
\text { Holienka, Zuzana } \\
\text { Kovačičová, Juraj Mikuš, } \\
\text { Ján Rehák }\end{array}$ & $\begin{array}{l}\text { Comenius University } \\
\text { in Bratislava, Faculty of } \\
\text { Management (UNIBA SK) } \\
\text { Slovak Business Agency } \\
\text { (SBA) }\end{array}$ & $\begin{array}{l}\text { Crystal Research, } \\
\text { a.s. }\end{array}$ \\
\hline Slovenija & $\begin{array}{l}\text { University of } \\
\text { Maribor, Faculty } \\
\text { of Economics and } \\
\text { Business, Institute } \\
\text { for Entrepreneurship } \\
\text { and Small Business } \\
\text { Management }\end{array}$ & $\begin{array}{l}\text { Miroslav Rebernik, Karin } \\
\text { Širec, Polona Tominc, } \\
\text { Barbara Bradač Hojnik, } \\
\text { Katja Crnogaj, Matej Rus }\end{array}$ & $\begin{array}{l}\text { MGRT - Ministry of } \\
\text { Economic Development } \\
\text { and Technology SPIRIT } \\
\text { Slovenia - Public Agency } \\
\text { for Entrepreneurship, } \\
\text { Internationalization, } \\
\text { Foreign Investments and } \\
\text { Technology }\end{array}$ & Mediana \\
\hline
\end{tabular}




\begin{tabular}{|c|c|c|c|c|}
\hline Tim & Ustanova & Člani tima & Finančni sponzorji & $\begin{array}{l}\text { Izvedba } \\
\text { anketiranja }\end{array}$ \\
\hline Španija & $\begin{array}{l}\text { Observatorio del } \\
\text { Emprendimiento de } \\
\text { España (OEE) } \\
\text { (formerly Asociación } \\
\text { RED GEM España) }\end{array}$ & $\begin{array}{l}\text { Ana Fernández Laviada } \\
\text { NATIONAL TEAM } \\
\text { Iñaki Peña, Maribel } \\
\text { Guerrero, José Luis } \\
\text { González, Javier Montero } \\
\text { REGIONAL TEAMS } \\
\text { José Ruiz Navarro (Director } \\
\text { GEM Andalucía), Lucio } \\
\text { Fuentelsaz Lamata, } \\
\text { (Director GEM Aragón), } \\
\text { Jesús Ángel del Brío } \\
\text { González, (Director } \\
\text { GEM Asturias), Julio } \\
\text { Batle Lorente (Director } \\
\text { GEM Baleares), Rosa M. } \\
\text { Batista Canino,(Director } \\
\text { GEM Canarias), Ana } \\
\text { Fernández-Laviada } \\
\text { (Director GEM Cantabria), } \\
\text { Carlos Guallarte (Director } \\
\text { GEM Cataluña), Juan } \\
\text { José Jiménez Moreno, } \\
\text { (Director GEM Castilla La } \\
\text { Mancha), Mariano Nieto } \\
\text { Antolín (Co-directorGEM } \\
\text { Castillay León), Nuria } \\
\text { González Álvarez (Co- } \\
\text { director GEM Castillay } \\
\text { León), Lázaro Rodriguez } \\
\text { Ariza (Director GEM Ceuta), } \\
\text { Isidro de Pablo Lopez } \\
\text { (Director GEM Madrid), } \\
\text { José María Gómez Gras } \\
\text { (Director GEM Comunidad } \\
\text { Valenciana), Ricardo } \\
\text { Hernández Mogollón, } \\
\text { (Co-director GEM } \\
\text { Extremadura), J. Carlos } \\
\text { Díaz Casero (Co-director } \\
\text { GEM Extremadura), Loreto } \\
\text { Fernández Fernández, } \\
\text { (Director GEM Galicia)., Luis } \\
\text { Alberto Ruano Marrón, } \\
\text { (Director GEM La Rioja), } \\
\text { María del Mar Fuentes } \\
\text { Fuentes (Director GEM } \\
\text { Melilla), Antonio Aragón } \\
\text { Sánchez (Co-director GEM } \\
\text { Murcia), Alicia Rubio Bañón } \\
\text { (Co-director GEM Murcia), } \\
\text { Ignacio Contin Pilart (Co-- } \\
\text { director GEM Navarra), } \\
\text { Martin Larraza Kintana } \\
\text { (Co-director GEM Navarra), } \\
\text { María Saiz Santos (Director } \\
\text { GEM País Vasco) }\end{array}$ & $\begin{array}{l}\text { Centro Internacional } \\
\text { Santander } \\
\text { Emprendimiento (CISE) } \\
\text { Santander Bank } \\
\text { (SANTANDER) } \\
\text { Empresa Nacional de } \\
\text { Innovación, SA (ENISA) }\end{array}$ & Opinometre \\
\hline
\end{tabular}




\begin{tabular}{|c|c|c|c|c|}
\hline Tim & Ustanova & Člani tima & Finančni sponzorji & $\begin{array}{l}\text { Izvedba } \\
\text { anketiranja }\end{array}$ \\
\hline Švedska & $\begin{array}{l}\text { Swedish } \\
\text { Entrepreneurship } \\
\text { Forum } \\
\text { (Entreprenörskaps- } \\
\text { forum) }\end{array}$ & $\begin{array}{l}\text { Pontus Braunerhjelm, Per } \\
\text { Thulin, Martin Svensson, } \\
\text { Marcus Larsson }\end{array}$ & $\begin{array}{l}\text { The Confederation of } \\
\text { Swedish Enterprise } \\
\text { (Svenskt Näringsliv) } \\
\text { The Swedish Agency for } \\
\text { Economic and Regional } \\
\text { Growth (Tillväxtverket) }\end{array}$ & AskSweden \\
\hline Švica & $\begin{array}{l}\text { School of Management } \\
\text { (HEG-FR) } \\
\text { University of Applied } \\
\text { Sciences and Arts } \\
\text { Western Switzerland } \\
\text { (HES-SO) }\end{array}$ & $\begin{array}{l}\text { Rico Baldegger, Raphael } \\
\text { Gaudart, Pascal Wild, } \\
\text { Gabriel Simonet }\end{array}$ & $\begin{array}{l}\text { School of Management } \\
\text { (HEG-FR) } \\
\text { University of Applied } \\
\text { Sciences and Arts Fribourg } \\
\text { (HES-FR) }\end{array}$ & Gfs Bern \\
\hline Tajvan & $\begin{array}{l}\text { Taiwan Institute of } \\
\text { Economic Research } \\
\text { (TIER) }\end{array}$ & $\begin{array}{l}\text { Xin-Wu Lin, Ju-Yin Tang, } \\
\text { Jia-Jing Lin }\end{array}$ & $\begin{array}{l}\text { Small and Medium } \\
\text { Enterprise Administration } \\
\text { (SEMA) }\end{array}$ & $\begin{array}{l}\text { China Credit } \\
\text { Information } \\
\text { Service }\end{array}$ \\
\hline Togo & $\begin{array}{l}\text { Coalition Nationale } \\
\text { pour l'Emploi des } \\
\text { Jeunes (CNEJ) }\end{array}$ & $\begin{array}{l}\text { Eric M. Tamandja, } \\
\text { Gnassingbe-E Odilia B., } \\
\text { Kola Koboyo, Abalo- } \\
\text { Koboyo Padakale, Ayao } \\
\text { Kokou-Maduvo, Korku Kofi } \\
\text { Soweto, Soklou Ahoefa } \\
\text { Immaculée, Abdel Adhime } \\
\text { A. A. Salami, Junien Roxan } \\
\text { Nze Biyoghe, Koulalo } \\
\text { Kodjo, Amewokunu Yao A. }\end{array}$ & $\begin{array}{l}\text { Coalition Nationale pour } \\
\text { l'Emploi des Jeunes (CNEJ) }\end{array}$ & $\begin{array}{l}\text { Centre autonome } \\
\text { d'études et de } \\
\text { renforcement } \\
\text { des capacités } \\
\text { pourle } \\
\text { développement } \\
\text { au Togo } \\
\text { (CADERDT) }\end{array}$ \\
\hline Urugvaj & $\begin{array}{l}\text { IEEM Business } \\
\text { School, University of } \\
\text { Montevideo }\end{array}$ & $\begin{array}{l}\text { Leonardo Veiga, Ana } \\
\text { Vignolo }\end{array}$ & $\begin{array}{l}\text { University of Montevideo/ } \\
\text { IEEM } \\
\text { National Development } \\
\text { Agency }\end{array}$ & \\
\hline $\begin{array}{l}\text { Velika } \\
\text { Britanija }\end{array}$ & $\begin{array}{l}\text { Aston Business } \\
\text { School, Aston } \\
\text { University }\end{array}$ & $\begin{array}{l}\text { Mark Hart, Karen Bonner, } \\
\text { Neha Prashar, Jonathan } \\
\text { Levie, Tomasz Mickiewicz, } \\
\text { Niels Bosma }\end{array}$ & $\begin{array}{l}\text { Department of Business, } \\
\text { Energy and Industrial Strategy } \\
\text { (UKGovernment) - BEIS } \\
\text { Department for the } \\
\text { Economy (Northern Ireland } \\
\text { Government) - DfE } \\
\text { Welsh Government } \\
\text { NatWest Bank Ltd } \\
\text { Hunter Centre of } \\
\text { Entrepreneurship, } \\
\text { Strathclyde Business School }\end{array}$ & $\begin{array}{l}\text { BMG Ltd, } \\
\text { Birmingham, UK }\end{array}$ \\
\hline $\begin{array}{l}\text { Združene } \\
\text { države } \\
\text { Amerike }\end{array}$ & Babson College & $\begin{array}{l}\text { Julian Lange, Candida } \\
\text { Brush, Andrew Corbett, } \\
\text { Donna Kelley, Phillip } \\
\text { Kim, Mahdi Majbouri, Sid } \\
\text { Vedula, Doug Scibeck }\end{array}$ & Babson College & Qualtrix \\
\hline $\begin{array}{l}\text { Združeni } \\
\text { arabski } \\
\text { emirati }\end{array}$ & $\begin{array}{l}\text { United Arab Emirates } \\
\text { University (UAEU) }\end{array}$ & $\begin{array}{l}\text { Nihel Chabrak, Elif } \\
\text { Bascavusoglu, Chafik } \\
\text { Bouhaddioui, Llewellyn } \\
\text { D. W. Thomas }\end{array}$ & Khalifa Fund & Kantar \\
\hline
\end{tabular}



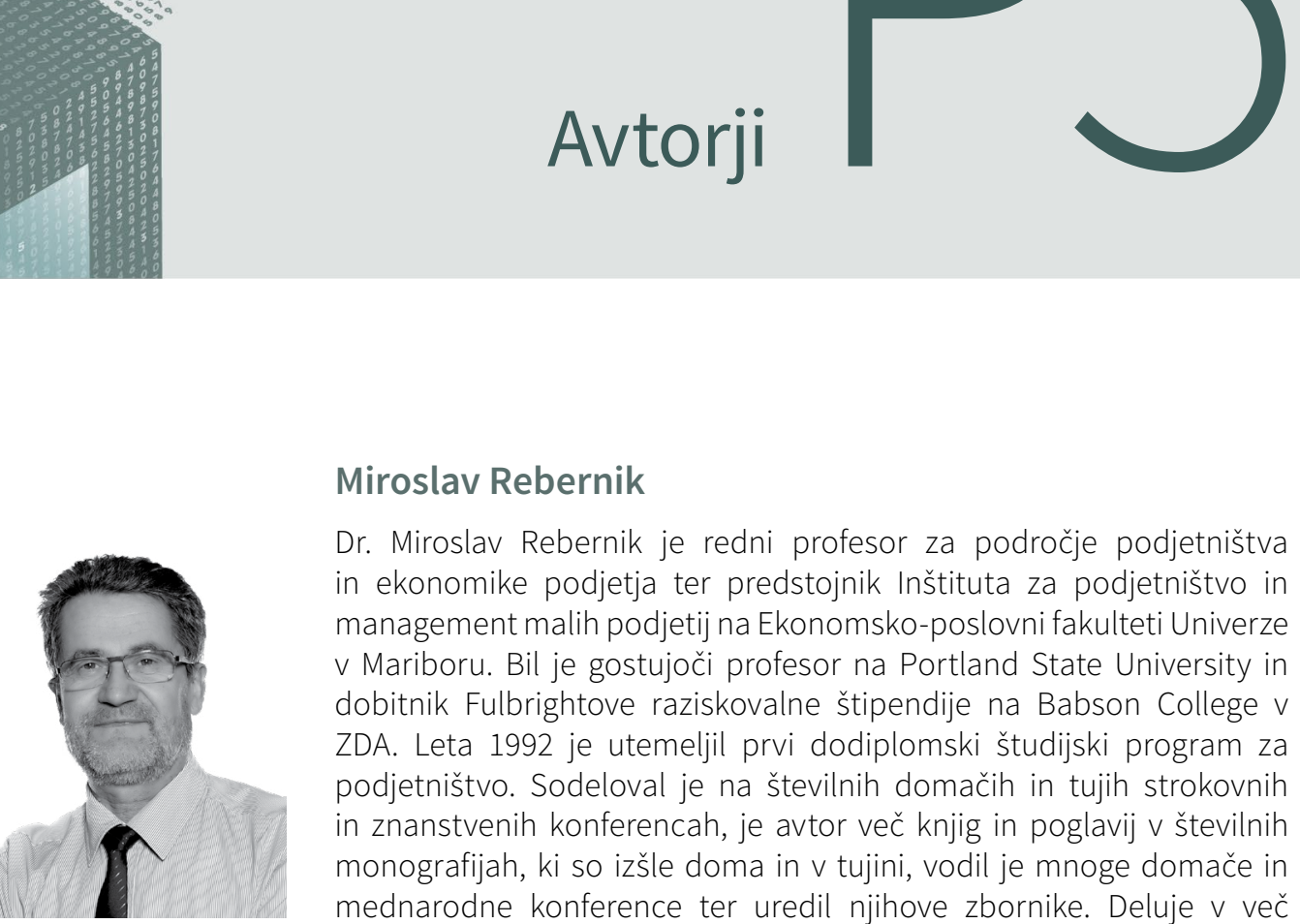

\section{Miroslav Rebernik}

Dr. Miroslav Rebernik je redni profesor za področje podjetništva in ekonomike podjetja ter predstojnik Inštituta za podjetništvo in management malih podjetij na Ekonomsko-poslovni fakulteti Univerze $\checkmark$ Mariboru. Bil je gostujoči profesor na Portland State University in dobitnik Fulbrightove raziskovalne štipendije na Babson College $v$ ZDA. Leta 1992 je utemeljil prvi dodiplomski študijski program za podjetništvo. Sodeloval je na številnih domačih in tujih strokovnih in znanstvenih konferencah, je avtor več knjig in poglavij v številnih monografijah, ki so izšle doma in v tujini, vodil je mnoge domače in mednarodne konference ter uredil njihove zbornike. Deluje $\vee$ več uredniških in recenzijskih odborih znanstvenih revij s področja podjetništva. Od leta 1999 vodi raziskovalni projekt in ekipo, ki ustvarja letni Slovenski podjetniški observatorij, od leta 2002 pa vodi slovensko ekipo raziskovalnega programa Global Entrepreneurship Monitor. Leta 2001 je soustanovil Tovarno podjemov (www.tovarnapodjemov. org), ki je kot podjetniški inkubator Univerze v Mariboru eden ključnih elementov podpornega okolja za podjetništvo univerzitetnega mesta Maribor in širše regije. Dlje časa je programsko vodil Mednarodno konferenco o inovacijah in podjetništvu PODIM (www.podim.org), sodeluje v pobudi Start:up Slovenija (www.startup.si) in Start:up Maribor (www.startupmaribor.si) ter različnih projektih s področja podjetništva. Dlje časa je bil član ekspertne komisije Evropske komisije SME Policy Relevant Research. 


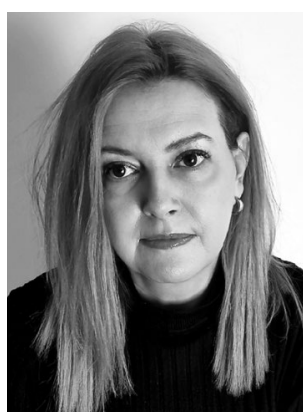

\section{Karin Širec}

Dr. Karin Širec je redna profesorica za področje podjetništva in ekonomiko poslovanja na Ekonomsko-poslovni fakulteti Univerze $\checkmark$ Mariboru in predstojnica Katedre za podjetništvo in ekonomiko poslovanja. $\vee$ raziskovalni skupini Inštituta za podjetništvo in management malih podjetij sodeluje pri dveh longitudinalnih raziskavah s področja podjetništva, in sicer pri Slovenskem podjetniškem observatoriju in Globalnem podjetniškem monitorju. Hkrati je tudi slovenska predstavnica mednarodne raziskovalne skupine za raziskovanje ženskega podjetništva DIANA in članica raziskovalnega programa Podjetništvo za inovativno družbo. Sodelovala je na številnih domačih in tujih strokovnih in znanstvenih konferencah. Je avtorica več znanstvenih in strokovnih člankov ter soavtorica več knjig in poglavij vštevilnih znanstvenih monografijah, ki posegajo na raziskovalna področja ekonomike podjetja, podjetništva, teorije proizvodnih virov, podjetniških teorij in teorij, ki temeljijo na znanju. Je predstavnica Slovenije pri Evropskem svetu za mala podjetja (European Council for Small Business), ekspertna svetovalka OECD za področje vključujočega podjetništva in članica fakultetnega senata. Pred zaposlitvijo na univerzi je delala v gospodarstvu.

\section{Barbara Bradač Hojnik}

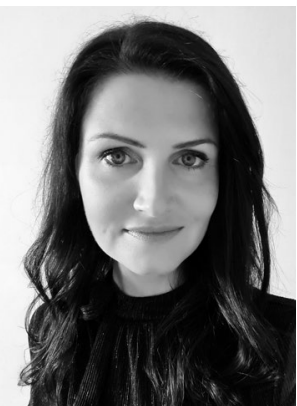

Dr. Barbara Bradač Hojnik je izredna profesorica za podjetništvo na Ekonomsko-poslovni fakulteti Univerze v Mariboru. Aktivno sodeluje $\checkmark$ pedagoškem procesu dodiplomskih in podiplomskih študijskih programov Katedre za podjetništvo in ekonomiko poslovanja. Kot članica raziskovalne skupine Inštituta za podjetništvo in management malih podjetij sodeluje $v$ več domačih in mednarodnih raziskovalnih projektih. Je članica raziskovalnih timov Slovenski podjetniški observatorij in Globalni podjetniški monitor Slovenija, vključena pa je tudi $v$ longitudinalni raziskovalni program Podjetništvo za inovativno družbo. Je avtorica več znanstvenih in strokovnih člankov ter monografij z raziskovalnih področij trajnostnega in korporacijskega podjetništva, podpornega okolja za podjetništvo in zunanjega izvajanja. Sodelovala je na več mednarodnih znanstvenih konferencah. Je predstojnica magistrske študijske usmeritve Podjetništvo in inoviranje na Ekonomsko-poslovni fakulteti in članica fakultetne komisije za znanstveno-raziskovalne zadeve. 


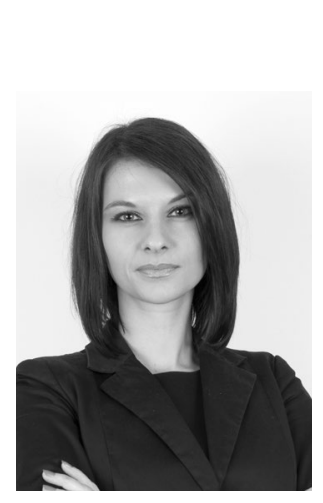

\section{Katja Crnogaj}

Dr. Katja Crnogaj je docentka za področje podjetništva na Ekonomskoposlovni fakulteti Univerze v Mariboru. Sodeluje v pedagoškem procesu dodiplomskih in podiplomskih študijskih programov, kot raziskovalka Inštituta za podjetništvo in management malih podjetij pa pri številnih domačih in mednarodnih raziskovalnih projektih. Je predstojnica univerzitetne študijske usmeritve Podjetništvo na Ekonomskoposlovni fakulteti, članica fakultetne komisije za študijske zadeve, članica raziskovalnega tima Globalni podjetniški monitor in Slovenski podjetniški observatorij ter članica komisije za področje ekonomije v projektu Mladi za napredek Maribora. Aktivno sodeluje v raziskovalnem programu Podjetništvo za inovativno družbo. V doktorski disertaciji je proučevala vpliv izbranih institucionalnih in individualnih dejavnikov na podjetniško aktivnost ter njihovo povezavo z gospodarskim in družbenim napredkom. Raziskovalno se ukvarja s področjem podjetništva in ekonomike poslovanja, rezultate raziskav pa objavlja v različnih znanstvenih in strokovnih revijah ter monografijah.

\section{Matej Rus}

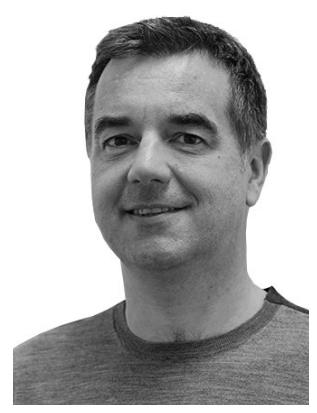

Mag. Matej Rus je visokošolski predavatelj za podjetništvo. Svoje moči usmerja v pedagoško in raziskovalno kariero, ki jo je začel leta 1996 na Ekonomsko-poslovni fakulteti Univerze v Mariboru, ter v svetovalno dejavnost $\vee$ podjetniški praksi. Leta 2001 je soustanovil Tovarno podjemov (www.tovarnapodjemov.org), ki je kot podjetniški inkubator Univerze v Mariboru eden ključnih elementov podpornega okolja za podjetništvo univerzitetnega mesta Maribor in širše regije. Kot direktor Tovarne podjemov in socialni podjetnik uresničuje začrtano vizijo podpore podjetnikom in podjetništvu. Tovarna podjemov pa ni samo univerzitetni inkubator, temveč tudi nosilec nacionalnega programa Start:up Slovenija, ki ga soorganizira s Slovenskim podjetniškim skladom in Ministrstvom za gospodarski razvoj in tehnologijo. V zadnjih letih kot član jedrne ekipe uspešno sokreira čezmejni program Start:up Alpe-Adria, ki ustvarja enoten čezmejni startup ekosistem in ga želi narediti prepoznavnega $\vee$ svetovnem merilu. Uspešne podjetniške, raziskovalne in svetovalne izkušnje prenaša v pedagoško delo in tako prispeva k dvigu uporabne vrednosti med študijem pridobljenih znanj. Med drugim je tudi organizacijski vodja mednarodne konference PODIM (www.podim.org), ekspert evropskega Startup Monitor Tracker ter nosilec naziva ambasador Startup Europe, programa EU komisije za podporo in promocijo podjetništva v Evropski uniji. Je tudi član posvetovalne skupine startup skupnosti pri Vladi RS ter član nacionalnega Sveta za razvoj v kmetijstvu, gozdarstvu in prehrano. 


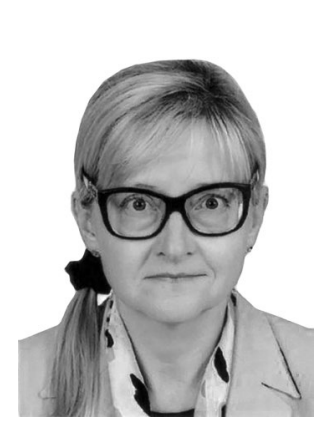

\section{Polona Tominc}

Dr. Polona Tominc je redna profesorica za področje kvantitativnih ekonomskih analiz na Ekonomsko-poslovni fakulteti Univerze $v$ Mariboru, predstojnica Katedre za kvantitativne ekonomske analize ter članica fakultetnega senata. V raziskovalni skupini Inštituta za podjetništvo in management malih podjetij sodeluje pri raziskavi Globalni podjetniški monitor, je članica mednarodne raziskovalne skupine za raziskovanje ženskega podjetništva DIANA in vodja raziskovalnega programa Podjetništvo za inovativno družbo na Ekonomsko-poslovni fakulteti Univerze v Mariboru. Sodelovala je na več kot 30 znanstvenih in strokovnih tujih in domačih konferencah, je avtorica ali soavtorica poglavij $v$ tujih in domačih znanstvenih monografijah ter znanstvenih in strokovnih člankov, objavljenih $v$ uveljavljenih tujih in domačih revijah. Aktivno sodeluje $v$ mednarodni mreži za proučevanje ženskega podjetništva DIANA. 


\title{
Podjetništvo v novi stvarnosti
}

\section{GEM Slovenija 2020}

\author{
Avtorji: \\ Miroslav Rebernik \\ Karin Širec \\ Barbara Bradač Hojnik \\ Katja Crnogaj \\ Matej Rus \\ Polona Tominc
}

\section{Povzetek:}

Podjetništvo je najmočnejše gonilo gospodarske rasti in razvoja in ima zelo velik vpliv na celoten družbeni razvoj. Globalni podjetniški monitor (GEM) ima za seboj zgodovino 22-letnega raziskovanja podjetništva s posebnim poudarkom na najbolj zgodnjih fazah, ko se zaznavajo poslovne priložnosti in se posamezniki odločajo, alise bodo ukvarjalis podjetništvom. Velikvpliv na vključevanje posameznikov $\checkmark$ podjetniške aktivnosti ima njihovo neposredno življenjsko okolje, predvsem prevladujoče kulturne vrednote, nagnjenost družbe k podjetništvu in urejenost poslovnega okolja. Temu ustrezno je zastavljen konceptualni okvir GEM, ki omogoča obravnavanje posameznikov in njihovega odnosa do podjetništva, dojemanja podjetništva ter vključenosti v ustanavljanje in/ali lastništvo in vodenje podjetja. Z njegovo pomočjo lahko zato dobimo bolj poglobljen vpogled v nacionalno podjetništvo in njegove značilnosti in bolj popolno sliko, kot jo lahko zagotovijo različni statistični viri, ki temeljijo zgolj na podatkih, pridobljenih od obstoječih podjetij. GEM namreč zajame tudi odnos posameznika in družbe do podjetništva, njegove ambicije in usposobljenost za podjetništvo, pa tudi posameznike $\checkmark$ vseh fazah podjetniškega procesa, od začetnih razmislekov, da bi se podali na podjetniško pot, do ustanovitve podjetja, poslovanja, rasti in prenehanja poslovanja. Zajame pa tudi notranje podjetništvo in posamezne bolj poglobljene teme, kot je recimo gig ekonomija (GEM 2019), vpliv pandemije covida-19 (GEM 2020) ali sledenje ciljem trajnostnega razvoja (GEM 2021).

\section{Ključne besede:}

Globalni podjetniški monitor, podjetništvo, celotna zgodnja podjetniška aktivnost, gospodarski razvoj, podjetniški ekosistem

\section{Naslovi avtorjev:}

Miroslav Rebernik, Univerza v Mariboru, Ekonomsko-poslovna fakulteta, Maribor, Slovenija, e-pošta: miroslav.rebernik@um.si.

Karin Širec, Univerza v Mariboru, Ekonomsko-poslovna fakulteta, Maribor, Slovenija, e-pošta:karin.sirec@um.si.

Barbara Bradač Hojnik, Univerza v Mariboru, Ekonomsko-poslovna fakulteta, Maribor, Slovenija, e-pošta: barbara.bradac@um.si.

Katja Crnogaj, Univerza v Mariboru, Ekonomsko-poslovna fakulteta, Maribor, Slovenija, e-pošta: katja.crnogaj@um.si.

Matej Rus, Univerza v Mariboru, Ekonomsko-poslovna fakulteta, Maribor, Slovenija, e-pošta:matej.rus@um.si.

Polona Tominc, Univerza v Mariboru, Ekonomsko-poslovna fakulteta, Maribor, Slovenija, e-pošta: polona.tominc@um.si.

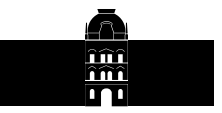




REPUBLIKA SLOVENIIA

MINISTRSTVO ZA GOSPODARSKI

RAZVOJ IN TEHNOLOGIJO

\section{WM SPIRIT \\ SLOVENIJA}

\section{ஏгॅ든}

JAVNA AGENCIJA ZA RAZISKOVALNO DEJAVNOST

REPUBLIKE SLOVENIJE

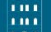

Univerza v Maribor

Ekonomsko-poslovna fakulteta

\section{ФIPMMP}

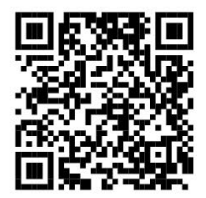

